Prepared in cooperation with the Bureau of Land Management, Bureau of Reclamation, Southwestern Water Conservation District, San Miguel County, and Telluride Power/Water

\title{
Assessment of Historical Surface-Water Quality Data in Southwestern Colorado, 1990-2005
}

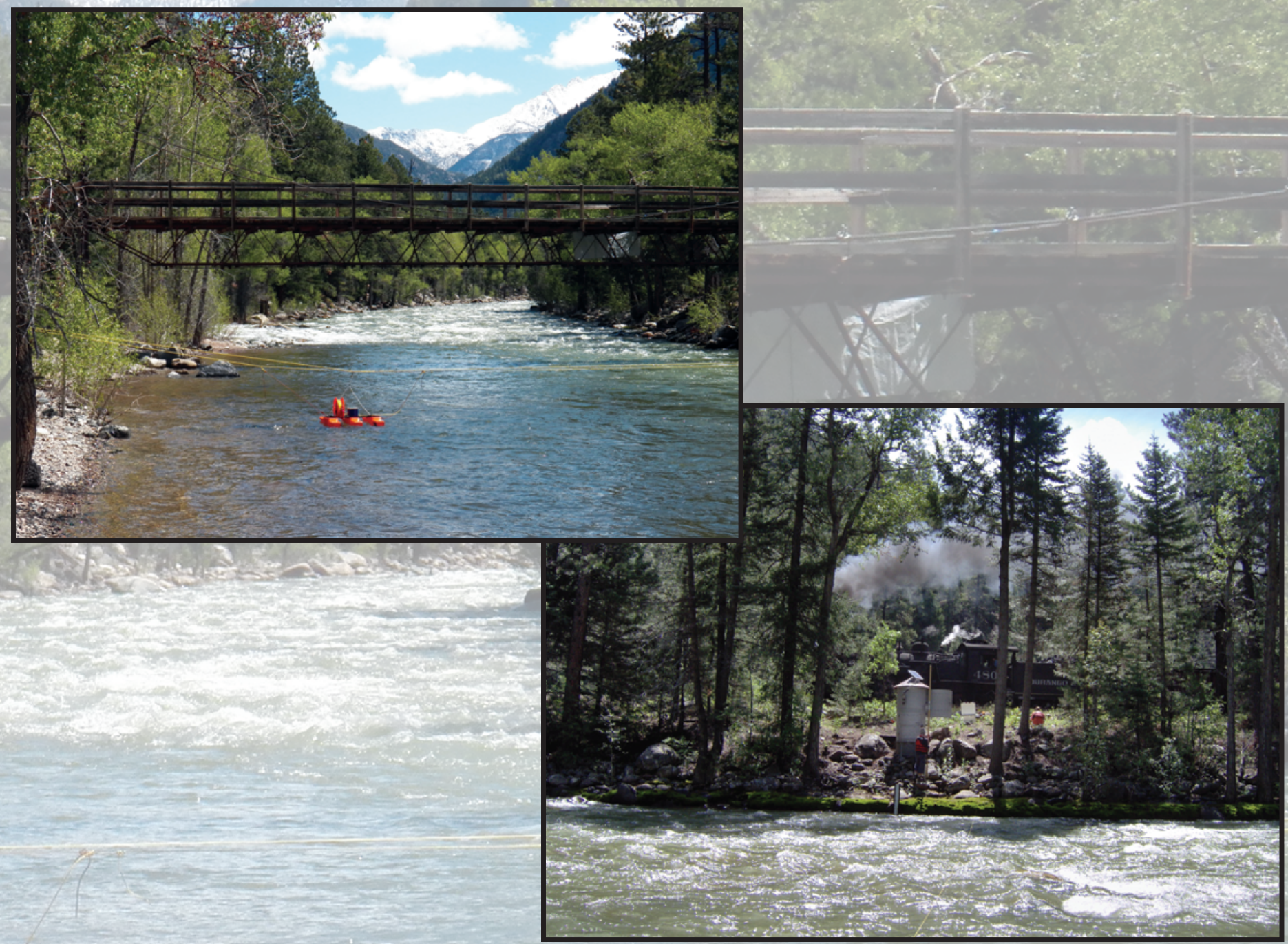

Scientific Investigations Report 2012-5255

U.S. Department of the Interior

U.S. Geological Survey 
COVER. Animas River at Tall Timber Resort above Tacoma, Colorado, U.S. Geological Survey streamgage 09359500 (photographs taken by David Grey, U.S. Geological Survey, May 8, 2012). 


\section{Assessment of Historical Surface-Water Quality Data in Southwestern Colorado, 1990-2005}

By Lisa D. Miller, Keelin R. Schaffrath, and Joshua I. Linard

Prepared in cooperation with the Bureau of Land Management, Bureau of Reclamation, Southwestern Water Conservation District, San Miguel County, and Telluride Power/Water

Scientific Investigations Report 2012-5255 


\section{U.S. Department of the Interior \\ KEN SALAZAR, Secretary}

\section{U.S. Geological Survey \\ Suzette M. Kimball, Acting Director}

U.S. Geological Survey, Reston, Virginia: 2013

For more information on the USGS - the Federal source for science about the Earth, its natural and living resources, natural hazards, and the environment, visit http://www.usgs.gov or call 1-888-ASK-USGS.

For an overview of USGS information products, including maps, imagery, and publications, visit http://www.usgs.gov/pubprod

To order this and other USGS information products, visit http://store.usgs.gov

Any use of trade, firm, or product names is for descriptive purposes only and does not imply endorsement by the U.S. Government.

Although this information product, for the most part, is in the public domain, it also may contain copyrighted materials as noted in the text. Permission to reproduce copyrighted items must be secured from the copyright owner.

Suggested citation:

Miller, L.D., Schaffrath, K.R., and Linard, J.I., 2013, Assessment of historical surface-water quality data in southwestern Colorado, 1990-2005: U.S. Geological Survey Scientific Investigations Report 2012-5255, 74 p. 


\section{Contents}

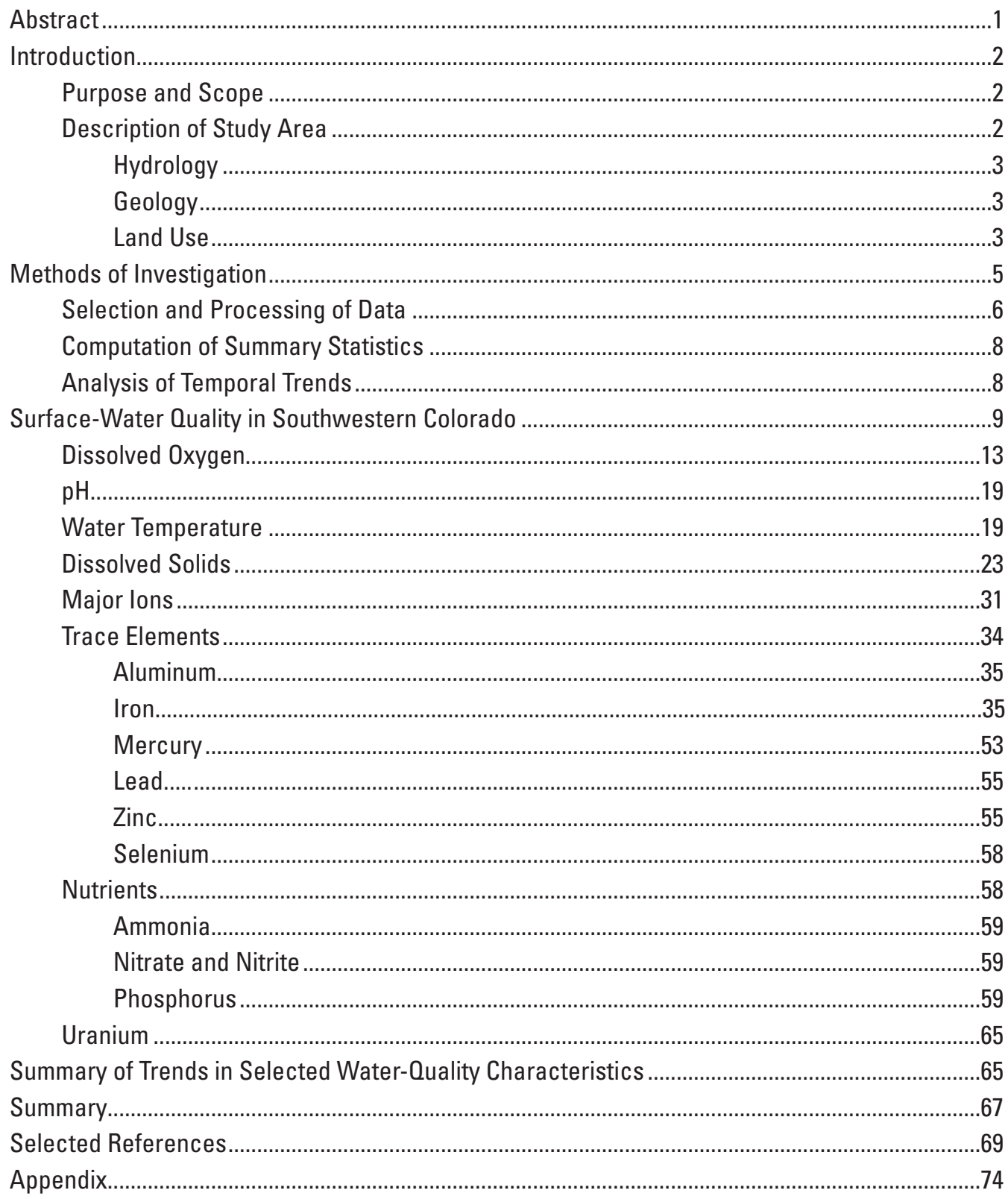

\section{Figures}

1. Map showing study area location and water-quality site locations, Dolores, Upper San Juan, and Lower San Juan River Basins, southwestern Colorado ..................4

2. Graph showing daily mean streamflow hydrograph for streamflow-gaging site Animas River at Silverton, Colorado (USGS 09359020), October 1991 through December 2005.

3. Map showing surface geology for southwestern Colorado ...............................................6

4. Map showing land use for southwestern Colorado ..................................................... 
5. Map showing spatial distribution of 15th percentile $\mathrm{pH}$ values in the Dolores, Upper San Juan, and Lower San Juan River Basins, southwestern Colorado, 1990-2005.

6. Graph showing monthly distribution of instantaneous dissolved-solids concentrations in surface water in the Dolores, Upper San Juan, and Lower San Juan River Basins, southwestern Colorado, 1990-2005....

7. Map showing spatial distribution of median dissolved-solids concentrations in the Dolores, Upper San Juan, and Lower San Juan River Basins, southwestern Colorado, 1990-2005

8. Piper diagram and location map showing water types for selected surface-water sites in the Dolores, Upper San Juan, and Lower San Juan River Basins, southwestern Colorado, 1990-2005.

9. Map showing spatial distribution of 85th percentile concentrations of dissolved aluminum in the Dolores, Upper San Juan, and Lower San Juan River Basins, southwestern Colorado, 1990-2005.

10. Map showing spatial distribution of median total recoverable iron concentrations in the Dolores, Upper San Juan, and Lower San Juan River Basins, southwestern Colorado, 1990-2005

11. Map showing spatial distribution of 85th percentile concentrations of dissolved lead in the Dolores, Upper San Juan, and Lower San Juan River Basins, southwestern Colorado, 1990-2005

12. Map showing spatial distribution of 85th percentile concentrations of dissolved zinc in the Dolores, Upper San Juan, and Lower San Juan River Basins, southwestern Colorado, 1990-2005

13. Map showing spatial distribution of 85th percentile concentrations of dissolved selenium in the Dolores, Upper San Juan, and Lower San Juan River Basins, southwestern Colorado, 1990-2005.

14. Map showing spatial distribution of 85th percentile concentrations of nitrate plus nitrite in the Dolores, Upper San Juan, and Lower San Juan River Basins, southwestern Colorado, 1990-2005

15. Map showing spatial distribution of maximum uranium concentrations in the Dolores, Upper San Juan, and Lower San Juan River Basins, southwestern Colorado, 1990-2005

\section{Tables}

1. List of sites and site location information, southwestern Colorado, 1990-2005.

2. Statistical summary for dissolved oxygen, $\mathrm{pH}$, and water-temperature data for sites with 10 or more samples in the Dolores, Upper San Juan, and Lower San Juan River Basins, southwestern Colorado, 1990-2005.

3. Summary of trend analysis results for dissolved-oxygen concentrations and $\mathrm{pH}$ and water temperature values in the Dolores, Upper San Juan, and Lower San Juan River Basins, southwestern Colorado, 1993-2003.

4. Statistical summary for dissolved solids and specific conductance data for sites with 10 or more samples in the Dolores, Upper San Juan, and Lower San Juan River Basins, southwestern Colorado, 1990-2005.

5. Summary of trend analysis results for dissolved-solids concentrations and specific-conductance values at selected sites in the Dolores, Upper San Juan, and Lower San Juan River Basins, southwestern Colorado, 1993-2003. 
6. Average major ion concentrations at selected sites in the Dolores, Upper San Juan, and Lower San Juan River Basins, southwestern Colorado, 1990-2005

7. Summary of trend analysis results for chloride, sulfate, and nitrate plus nitrite concentrations for selected sites in the Dolores, Upper San Juan, and Lower San Juan River Basins, southwestern Colorado, 1993-2003.

8. Summary of selected trace element concentrations at sites with 10 or more samples in the Dolores, Upper San Juan, and Lower San Juan River Basins, southwestern Colorado, 1990-2005.

9. Summary of trend analysis results for selected trace metals at sites in the Upper San Juan River Basin, southwestern Colorado, 1991-2004.

10. Statistical summary for total ammonia, nitrate plus nitrite, and total phosphorus concentrations for sites with 10 or more samples in the Dolores, Upper San Juan, and Lower San Juan River Basins, southwestern Colorado, 1990-2005. 


\section{Conversion Factors}

SI to Inch/Pound

\begin{tabular}{lcl}
\hline \multicolumn{1}{c}{ Multiply } & By & \multicolumn{1}{c}{ To obtain } \\
\hline millimeter $(\mathrm{mm})$ & Length & \\
meter $(\mathrm{m})$ & 0.03937 & inch (in.) \\
meter $(\mathrm{m})$ & 3.281 & foot $(\mathrm{ft})$ \\
\hline & 1.094 & yard $(\mathrm{yd})$ \\
\hline liter $(\mathrm{L})$ & Volume & \\
cubic meter $\left(\mathrm{m}^{3}\right)$ & 0.2642 & gallon $(\mathrm{gal})$ \\
liter $(\mathrm{L})$ & 264.2 & gallon $(\mathrm{gal})$ \\
cubic meter $\left(\mathrm{m}^{3}\right)$ & 61.02 & cubic inch $\left(\mathrm{in}^{3}\right)$ \\
\hline & 35.31 & cubic foot $\left(\mathrm{ft}^{3}\right)$ \\
\hline cubic meter per second $\left(\mathrm{m}^{3} / \mathrm{s}\right)$ & Flow rate & \\
meter per second $(\mathrm{m} / \mathrm{s})$ & 70.07 & acre-foot per day $(\mathrm{acre}-\mathrm{ft} / \mathrm{d})$ \\
cubic meter per second $\left(\mathrm{m}^{3} / \mathrm{s}\right)$ & 3.281 & foot per second $(\mathrm{ft} / \mathrm{s})$ \\
\hline & 35.31 & cubic foot per second $\left(\mathrm{ft}^{3} / \mathrm{s}\right)$ \\
\hline gram $(\mathrm{g})$ & Mass & \\
kilogram $(\mathrm{kg})$ & 0.03527 & ounce, avoirdupois $(\mathrm{oz})$ \\
\hline
\end{tabular}

Temperature in degrees Celsius $\left({ }^{\circ} \mathrm{C}\right)$ may be converted to degrees Fahrenheit $\left({ }^{\circ} \mathrm{F}\right)$ as follows:

${ }^{\circ} \mathrm{F}=\left(1.8 \times^{\circ} \mathrm{C}\right)+32$

Temperature in degrees Fahrenheit $\left({ }^{\circ} \mathrm{F}\right)$ may be converted to degrees Celsius $\left({ }^{\circ} \mathrm{C}\right)$ as follows:

${ }^{\circ} \mathrm{C}=\left({ }^{\circ} \mathrm{F}-32\right) / 1.8$

Vertical coordinate information is referenced to the North American Vertical Datum of 1988 (NAVD 88).

Horizontal coordinate information is referenced to the North American Datum of 1983 (NAD 83).

Altitude, as used in this report, refers to distance above the vertical datum.

Specific conductance is given in microsiemens per centimeter at 25 degrees Celsius $(\mu \mathrm{S} / \mathrm{cm}$ at $\left.25^{\circ} \mathrm{C}\right)$.

Concentrations of chemical constituents in water are given either in milligrams per liter (mg/L) or micrograms per liter $(\mu \mathrm{g} / \mathrm{L})$. 


\section{Abbreviations Used in this Report}

$\begin{array}{ll}\text { BLM } & \text { Bureau of Land Management } \\ \text { BOR } & \text { Bureau of Reclamation } \\ \text { CDPHE } & \text { Colorado Department of Public Health and Environment } \\ \text { Commission } & \text { Colorado Water Quality Control Commission } \\ \text { CWODR } & \text { Colorado Water-Quality Data Repository } \\ \text { DO } & \text { dissolved oxygen } \\ \text { DS } & \text { dissolved solids } \\ \text { ESTREND } & \text { EStimate TREND } \\ \text { FDA } & \text { Food and Drug Administration } \\ \text { HUC } & \text { Hydrologic Unit Code } \\ \text { IOR } & \text { interquartile range (IQR) } \\ \text { LRL } & \text { laboratory reporting level } \\ \text { MWAT } & \text { maximum weekly average temperature } \\ \text { NWIS } & \text { National Water Information System database } \\ \text { Ppm } & \text { parts per million } \\ \text { SC } & \text { specific conductance } \\ \text { SJRB } & \text { San Juan River Basin } \\ \text { STORET } & \text { STOrage and RETrieval } \\ \text { USEPA } & \text { U.S. Environmental Protection Agency } \\ \text { USGS } & \text { U.S. Geological Survey } \\ \text { NWOL } & \text { National Water Ouality Laboratory } \\ \text { WCD } & \text { Water Conservation District } \\ \text { WWTP } & \text { waste water treatment plant } \\ \end{array}$





\title{
Assessment of Historical Surface-Water Quality Data in Southwestern Colorado, 1990-2005
}

\author{
By Lisa D. Miller, Keelin R. Schaffrath, and Joshua I. Linard
}

\section{Abstract}

The spatial and temporal distribution of selected physical and chemical surface-water-quality characteristics throughout southwestern Colorado were analyzed using historical data collected from 1990 through 2005 by various local, State, Tribal, and Federal agencies. This analysis was done to provide an understanding of existing water-quality conditions in the Dolores River and San Juan River basins in southwestern Colorado as part of a larger surface-water and groundwater assessment conducted by the U.S. Geological Survey in cooperation with Bureau of Land Management, Bureau of Reclamation, Southwestern Water Conservation District, San Miguel County, and Telluride Power/Water. Summary statistics were calculated for selected physical and chemical surface-water water-quality characteristics at sites with 10 or more samples. These values were then compared and described spatially. Temporal trends in surface-water waterquality characteristics were calculated at sites with adequate data to determine if changes in values had occurred over time.

Overall, streams throughout the study area were well oxygenated. Median dissolved-oxygen concentrations generally ranged from 8 to 10 milligrams per liter $(\mathrm{mg} / \mathrm{L})$ in surface water. Values of $\mathrm{pH}$ generally were near neutral to slightly alkaline throughout most of the study area with the exception of the upper Animas River Basin near Silverton where acidic conditions existed at some sites because of hydrothermal alteration and(or) historical mining. Mean water temperatures in the study area ranged from 5.3 to $14.1^{\circ} \mathrm{C}$. Median dissolved solids (DS) concentrations ranged from 8 to $42,600 \mathrm{mg} / \mathrm{L}$. The highest DS concentrations typically occurred in samples collected from December through March when streamflows were lowest; and the lowest DS concentrations typically occurred in samples collected from May through July when streamflows were highest. Seasonal differences in DS concentrations were more apparent in samples from the Upper San Juan River Basin (SJRB) and the Lower SJRB than the Dolores River Basin.

In southwestern Colorado, 85th percentile concentrations for dissolved aluminum ranged from less than 50 to 67,000 micrograms per liter $(\mu \mathrm{g} / \mathrm{L})$; and median total recoverable aluminum concentrations ranged from less than 57 to $2,000 \mu \mathrm{g} / \mathrm{L}$. The highest aluminum concentrations were measured at sites located in the Cement and Mineral Creek Basins north and west of Silverton.

Median total recoverable iron concentrations ranged from 1.6 to $225,000 \mu \mathrm{g} / \mathrm{L}$. It was common for total recoverable iron concentrations to vary over several orders of magnitude at a given site. The highest median total recoverable iron concentrations in the study area generally occurred at sites in the Cement Creek and Mineral Creek Basins in the Upper SJRB north and west of Silverton.

Concentrations of total mercury measured in samples ranged from less than 0.005 to $12 \mu \mathrm{g} / \mathrm{L}$. Thirty-two sites had at least one measured concentration of total mercury that exceeded the chronic aquatic-life criterion of $0.01 \mu \mathrm{g} / \mathrm{L}$. Determining the actual distribution of mercury in surface water throughout the study area was not possible because reporting limits often varied at sites and most concentrations were reported as less than the individual reporting limits (that is, the values were censored).

In the Dolores River Basin, only two sites had 85th percentile concentrations of dissolved lead greater than the individual reporting limits. Both sites had 85 th percentile concentrations of dissolved lead equal to $1 \mu \mathrm{g} / \mathrm{L}$. The 85 th percentile concentrations for dissolved lead ranged from less than 1 to $250 \mu \mathrm{g} / \mathrm{L}$ at sites in the Upper SJRB. The highest dissolved lead concentrations in the Upper SJRB generally occurred in the Mineral and Cement Creek Basins. State criteria in these areas were based on total recoverable lead concentrations, and median concentrations of total recoverable lead did not exceed criteria. In the Lower SJRB, almost all dissolved lead concentrations were censored.

The 85th percentile concentrations for dissolved zinc ranged from less than 2 to $180,000 \mu \mathrm{g} / \mathrm{L}$; although, most sites in the study area generally had concentrations less than $200 \mu \mathrm{g} / \mathrm{L}$. Four sites in the Dolores River Basin had dissolved zinc concentrations that exceeded State acute and chronic hardness-based criteria. Twenty-four sites in the Upper SJRB had 85th percentile concentrations that exceeded acute and chronic hardness-based standards. Sites that exceeded State acute and chronic hardness-based standards in the Upper SJRB may not have exceeded segment-specific monthly standards, but monthly concentrations were not calculated. In the Lower SJRB, 85th percentile concentrations of dissolved zinc were well below the State hardness-based criteria. 
Dissolved selenium concentrations in samples collected throughout the study area ranged from less than 0.2 to $170 \mu \mathrm{g} / \mathrm{L}$. One site in the Dolores River Basin, Salt Creek at Highway 141, had an 85th percentile concentration of dissolved selenium of $23 \mu \mathrm{g} / \mathrm{L}$ which exceeded the State chronic $(4.6 \mu \mathrm{g} / \mathrm{L})$ and acute water-quality standards $(18.4 \mu \mathrm{g} / \mathrm{L})$. The State chronic water-quality standard was also exceeded at one site in the Upper SJRB and one site in the Lower SJRB. Dissolved selenium concentrations greater than the acute water-quality standard were measured in some samples collected from Navajo Wash in the southwestern corner of the Upper SJRB and in some samples from Mud Creek sites near Cortez; but insufficient data were available to compute summary statistics.

Concentrations of total ammonia, nitrate, nitrite, and total phosphorus generally were low throughout the study area. The 85th percentile concentrations of total ammonia were less than the calculated chronic and acute State table-value water-quality standards for total ammonia. Nitrate plus nitrite concentrations ranged from less than 0.05 to $15 \mathrm{mg} / \mathrm{L}$ in samples; and 87 percent of samples analyzed had concentrations less than or equal to $0.5 \mathrm{mg} / \mathrm{L}$. In the Dolores River Basin, 85th percentile nitrate plus nitrite concentrations at the 21 sites analyzed ranged from less than 0.05 to $0.78 \mathrm{mg} / \mathrm{L}$. In the Upper SJRB, 85th percentile nitrate plus nitrite concentrations ranged from less than 0.06 to $2.4 \mathrm{mg} / \mathrm{L}$. Only 4 of the 35 sites analyzed in the Upper SJRB had 85th percentile concentrations of nitrate plus nitrite that exceeded $1 \mathrm{mg} / \mathrm{L}$. These sites were located in the vicinity of Durango mostly on the Animas River. In the Lower SJRB, 85th percentile nitrate plus nitrite concentrations at the two sites analyzed were $1 \mathrm{mg} / \mathrm{L}$ and $2.7 \mathrm{mg} / \mathrm{L}$. Total phosphorus concentrations ranged from less than 0.002 to $11 \mathrm{mg} / \mathrm{L}$, though concentrations in most samples were less than $0.1 \mathrm{mg} / \mathrm{L}$.

Only 10 sites throughout the entire study area had adequate data to calculate summary statistics for dissolved uranium. The 85th percentile concentrations of dissolved uranium ranged from less than 3 to $10 \mu \mathrm{g} / \mathrm{L}$, well below the national drinking water water-quality standard of $30 \mu \mathrm{g} / \mathrm{L}$. Although dissolved uranium concentrations in most samples from most streams were less than $5 \mu \mathrm{g} / \mathrm{L}$, concentrations of dissolved uranium greater than $10 \mu \mathrm{g} / \mathrm{L}$ were measured in some samples at various locations throughout the study area, particularly at sites in the Lower SJRB and along Navajo Wash in the Upper SJRB. Many of these site locations, where dissolved uranium concentrations were elevated, coincide with areas where the Mancos Shale crops out.

Overall results from the trend analyses indicate improvement in water-quality conditions as a result of operation of the Paradox Valley Unit in the Dolores River Basin and irrigation and water-delivery system improvements made in the McElmo Creek Basin and Mancos River Valley. Other detected trends may be because of precipitation variability during the analysis period. Additional study, however, would be needed to determine the causes of the apparent changes in water-quality characteristic values over time at the sites.

\section{Introduction}

Water is a valuable resource in southwestern Colorado used for municipal, recreational, agricultural, industrial, livestock, domestic, and mining purposes. Wildfires, past and present mining activities, atmospheric deposition of chemicals, urban development, and agricultural land use, among other things, have the potential to affect water quality throughout southwestern Colorado. An understanding of the present water-quality conditions is needed to effectively manage this valuable and limited resource. In 2004, the U.S. Geological Survey (USGS) in cooperation with Bureau of Land Management (BLM), Bureau of Reclamation (BOR), Southwestern Water Conservation District (WCD), San Miguel County, and Telluride Power/Water began a surface-water and groundwater assessment of the Dolores River and San Juan River Basin in Colorado. As part of this assessment, historical waterquality data collected in the Dolores River and San Juan River Basins (Southwest Study Area) by various local, State, Tribal, and Federal agencies were compiled into a single electronic database. This database is available on the Internet at the Colorado Water-Quality Data Repository (CWQDR) Web site at http://rmgsc.cr.usgs.gov/cwqdr/Southwest/index.shtml. Selected surface-water water-quality data for the Southwest study area (henceforth referred to as southwestern Colorado) were retrieved from the CWQDR. These data were analyzed to determine the spatial and temporal distribution of physical and chemical water-quality characteristics throughout southwestern Colorado. Results from this analysis along with descriptions from previous work by others were used to describe environmental and land-use factors which affect surface-water water-quality conditions in southwestern Colorado.

\section{Purpose and Scope}

The purpose of this report is to (1) describe the spatial and temporal distribution of historical physical and chemical data for streams in southwestern Colorado, (2) provide a statistical summary of historical surface-water water-quality data including minimum, maximum, median, and other selected percentile values for sites with 10 or more samples, (3) compare historical surface-water water-quality data to State and(or) Federal water-quality standards, and (4) describe trends in selected water-quality characteristics with sufficient data at selected sites. This report used surface-water waterquality data from 1990 through 2005 collected by multiple entities throughout the Dolores and San Juan River Basins in southwestern Colorado.

\section{Description of Study Area}

The Dolores River and San Juan River Basins were defined topographically and by the Colorado State boundary for the purposes of this report. The San Juan River Basin was 
subdivided into the Upper San Juan River Basin (Upper SJRB) and Lower San Juan River Basin (Lower SJRB) (fig. 1) based on the corresponding 6-digit Hydrologic Unit Code (HUC) (Seaber and other, 1987). Elevations in the Dolores River Basin ranged from 1,359 meters to 4,345 meters above the North American Vertical Datum of 1988 (U.S. Geological Survey, 1999). In the Lower SJRB, the elevations ranged from 1,399 meters to 3,041 meters. Upper SJRB elevations ranged from 1,435 meters to 4,311 meters (U.S. Geological Survey, 1999).

\section{Hydrology}

The mean annual precipitation throughout southwestern Colorado was variable. Mean annual precipitation (19712000) ranged from 27 to 134 millimeters ( $\mathrm{mm}$ ) in the Dolores River Basin, from 18 to $153 \mathrm{~mm}$ in the Upper SJRB, and from 18 to $60 \mathrm{~mm}$ in the Lower SJRB (Daly and others, 2002). Most precipitation in southwestern Colorado falls in the form of snow. Annual streamflow is dominated by spring snowmelt (fig. 2). An increase in streamflow is common throughout the study area beginning in April, peaking in May or June, and decreasing into autumn as snowmelt subsides. Streamflow from November through March typically remains relatively constant (fig. 2).

Understanding hydrologic characteristics is essential to understanding water quality. Concentrations of selected waterquality characteristics are often related to the magnitude of streamflow (Leib and others, 2003). A pattern measured in many streams is a tendency for water during a rising stage to have considerably higher concentrations of selected constituents than water at an equal flow rate after peak discharge has passed (Hem, 1985). In addition to short-term changes in concentrations related to stormflow, concentrations of certain water-quality characteristics vary based on seasonal streamflow characteristics. Zinc and copper concentrations tended to be higher during periods of base flow from November through March than during periods of higher flows from April through October (Besser and Leib, 1999). Similarly, the concentration of dissolved solids (DS) often has an inverse relation to streamflow (Hem, 1985). Concentrations of DS tend to increase during base flow conditions and decrease as streamflow rises (Miller and others, 2010). The main source of streamflow during base flow conditions is typically groundwater. Higher concentrations of DS generally are present in groundwater than snowmelt and(or) rainfall runoff (the main sources of streamflow during high flows in the study area), because groundwater generally has longer contact time with rocks and soil, and thus, more time to dissolve and gain substances.

\section{Geology}

The geology underlying southwestern Colorado includes igneous, metamorphic and sedimentary rocks (fig. 3). In the
San Juan Mountains, Paleogene volcanic rocks of the Silverton caldera (fig. 3) are underlain by Precambrian igneous and metamorphic rocks (Paschke and others, 2005). Leib and others (2003) and Mast and others (2000) indicated that water draining from within the boundary of the Silverton caldera could be acidic and have high concentrations of dissolved minerals. Moving west and south, Cretaceous shales and sandstones are the most common form of bedrock (Butler and others, 1997; Church and others, 2007). Cretaceous shales underlying areas of southwestern Colorado are prevalent throughout the Dolores River Basin, and exist in some near stream areas in the Lower SJRB and Upper SJRB. Morrison Formation sandstones are commonly found at lower elevations in the Dolores River Basin and Lower SJRB. In the McElmo Creek Basin near Cortez, groundwater flowing out of the Morrison Formation contributes to high in-stream concentrations of sodium, sulfate, chloride, magnesium, and calcium ions (Richards and Leib, 2011).

In the Dolores River Basin, groundwater moving through the Paradox Valley, a collapsed salt anticline, transports large amounts of DS to the Dolores River (Chafin, 2003). Under natural conditions, saline groundwater inflow contributes about 205,000 tons per year of DS to the Dolores River as it flows through the Paradox Valley (Bureau of Reclamation, 2011). The BOR constructed the Paradox Valley Unit as part of the Colorado River Basin Salinity Control Act of 1974 (Public Law 93-320, amended in 1984 as Public Law 98-569) to reduce the amount of DS (often referred to as salinity) entering the Dolores River, a tributary of the Colorado River. The Paradox Unit consists of a series of production wells that intercept the saline water before it enters the river, a surface treatment facility, an injection facility, and a deep injection well to dispose of the saline water (Bureau of Reclamation, 2011). Watts (2000) reported that "test operation of the Paradox Valley Unit began in 1990 and production operation began in 1996." Operation of the Paradox Valley Unit was changed in about 1998 to optimize interception of the brine inflow according to Chafin (2003). As a result of operation of the Paradox Valley Unit, DS loads in the Dolores River have been reduced by as much as 90 percent of historic DS loads (Chafin, 2003).

\section{Land Use}

The effects of geology on water quality can be exacerbated by anthropogenically induced changes to the land surface. The primary land-use and land-cover classifications in the study area are forest, rangeland, tundra, and agricultural land (fig. 4) (TechniGraphics, Inc., 2004). Forests are the dominant land cover in southwestern Colorado and occupy about 75 percent of the Dolores River Basin, 65 percent of the Upper SJRB, and 37 percent of the Lower SJRB (TechniGraphics, Inc., 2004). Rangeland is the next largest land-cover category in each river basin, comprising 19 percent of the Dolores River Basin, 24 percent of the Upper SJRB and 35 percent of the Lower SJRB (TechniGraphics, Inc., 2004). 


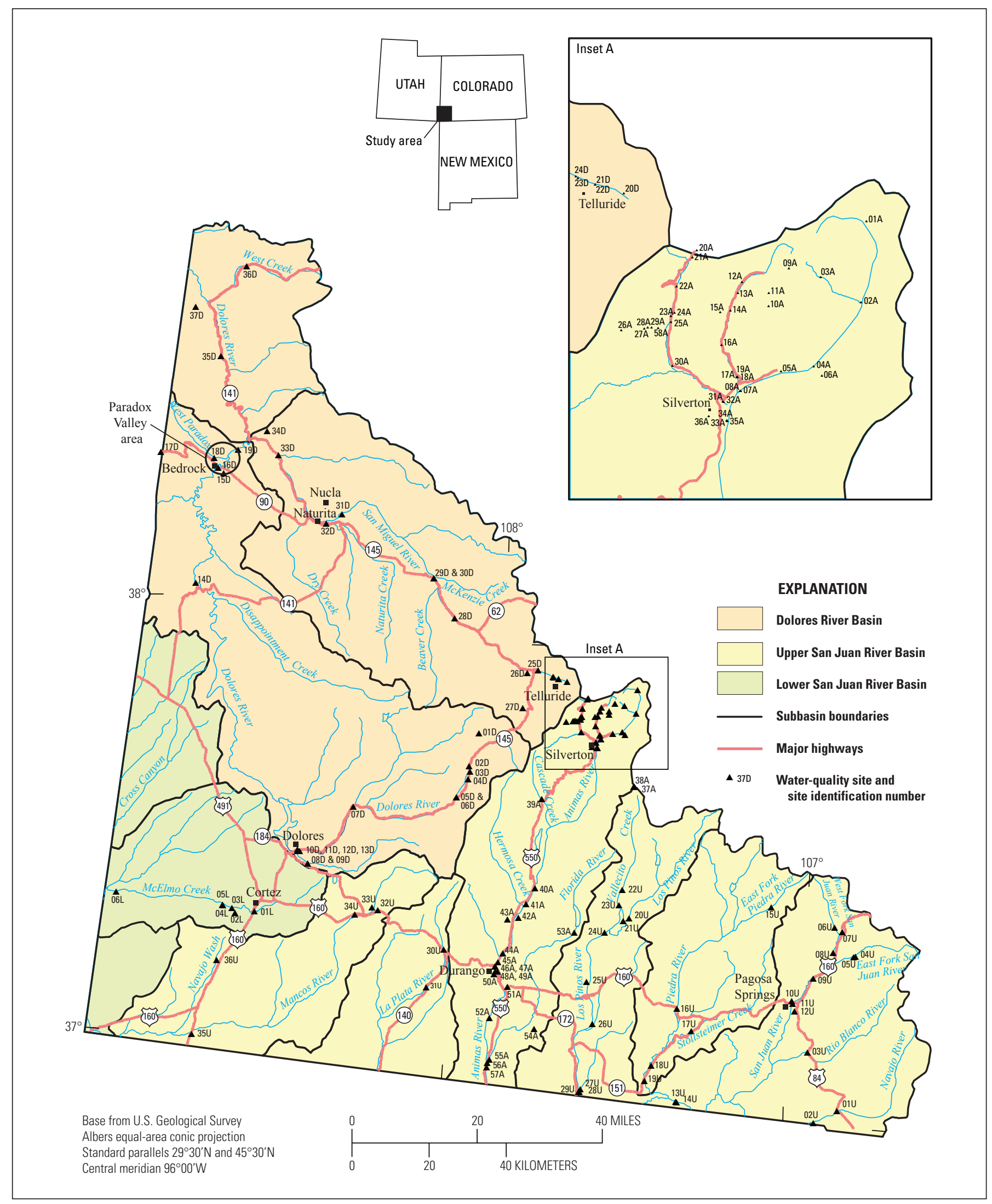

Figure 1. Map showing study area location and water-quality site locations, Dolores, Upper San Juan, and Lower San Juan River Basins, southwestern Colorado. 


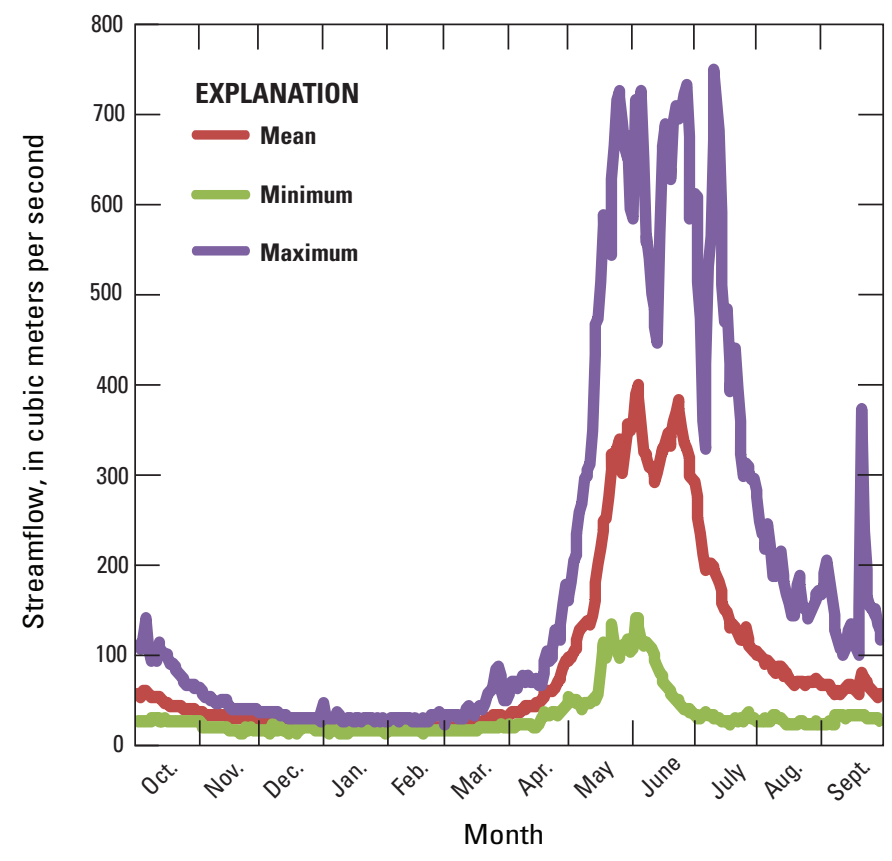

Figure 2. Graph showing daily mean streamflow hydrograph for streamflow-gaging site Animas River at Silverton, Colorado (USGS 09359020), October 1991 through December 2005.

Of the remaining land-cover and land-use categories, only tundra and agricultural land occupy greater than 1 percent of the river basin area. In the Upper SJRB, 4 percent of the land is classified as tundra and 5 percent as agricultural. Twentyseven percent of the land in the Lower SJRB is classified as agricultural land use.

Settlements in southwestern Colorado generally began in the late 1800 s with people lured by mining prospects and vast areas of grazing land. Many mines were created to extract the rich mineral wealth of the San Juan Mountains and currently (2011) their effect on downstream water quality is a concern to many stakeholders in the basin. In addition to the mines themselves, the infrastructure set up to transport and process/extract minerals has affected water quality particularly within the Animas River Basin. The abandoned mine sites increase the rate of rock weathering due to increased surface area exposure and $\mathrm{pH}$ changes; as a result, high concentrations of dissolved minerals drain from some of the mine areas (Leib and others, 2003). Mines also can divert groundwater from its pre-mining flow path and accelerate the weathering of more soluble rocks.

Urban and agricultural activities can often act to increase DS, nutrient, and sediment loading to streams, increase stream water temperatures, and alter channel geomorphology which may result in increased growth of aquatic organisms. Although agricultural land use was only a small part of the total land use in southwestern Colorado in 2000 (TechniGraphics, Inc., 2004), irrigated agricultural lands were often located near streams. Irrigation can accelerate the movement of agricultural chemicals to streams and increase dissolution of minerals.
Dissolved solids also concentrate in water as a result of evapotranspiration from crops and other vegetation, evaporation from canals and reservoirs, and evaporation from the land surface. The variation in the magnitude of selenium concentration and load in streams in southwestern Colorado is directly related to the application of irrigation water on soils derived from the Mancos Shale (Thomas and others, 2008; Butler and others, 1996; Wright and Butler, 1993; Butler, 2001; Butler and Leib, 2002).

The Mancos Shale in southwestern Colorado is an Upper Cretaceous, massive, and fossiliferous marine shale with interbedded sandstone, siltstone, and layers of devitrified volcanic ash (Wright and Butler, 1993) and is the stratigraphic equivalent of the Pierre Shale in southeastern Colorado.

Zielinski and others (1995) found that natural oxidative weathering of uranium-bearing marine shale bedrock, leaching of shale-derived soils, and evaporative concentration produces average dissolved uranium concentrations that approach or exceed $20 \mu \mathrm{g} / \mathrm{L}$ in surface water and shallow groundwater in southeastern Colorado. In addition, extensive use and reuse of water for irrigation further elevated dissolved uranium concentrations in irrigation return flow by increasing the amount of water/soil and water/rock interaction and the potential for evaporative concentration (Zielinski and others, 1995).

\section{Methods of Investigation}

Selection and processing of surface-water data, graphical presentations, and methods used to determine temporal trends for selected water-quality characteristics at sites with adequate data are described in this section and its subsections. Electronically available historical surface-water water-quality data for the Dolores River and San Juan River Basins in southwestern Colorado (Southwest study area) were retrieved from the CWQDR Web site http://rmgsc.cr.usgs.gov/cwqdr/Southwest/ index.shtml. Data stored in the CWQDR were collected by multiple entities over various periods of time. Water-quality concentrations characterized throughout the report are given as dissolved unless otherwise noted in the text. Dissolved concentrations are generally determined using the portion of the sample (filtrate) remaining after it has been filtered through a 0.45-micron or smaller filter (Colorado Department of Public Health and Environment, 2010b). Dissolved solids concentration data presented in this report were either reported as residual on evaporation at 180 degrees Celsius $\left({ }^{\circ} \mathrm{C}\right)$ or as the sum of constituents. The term "sum of constituents" refers to the method for determining a DS concentration in a sample as the sum of the concentrations of the major ions in the sample. The major dissolved ions in most water samples generally are calcium, magnesium, sodium, potassium, sulfate, chloride, fluoride, nitrate, bicarbonate, and carbonate (Hem, 1985). 


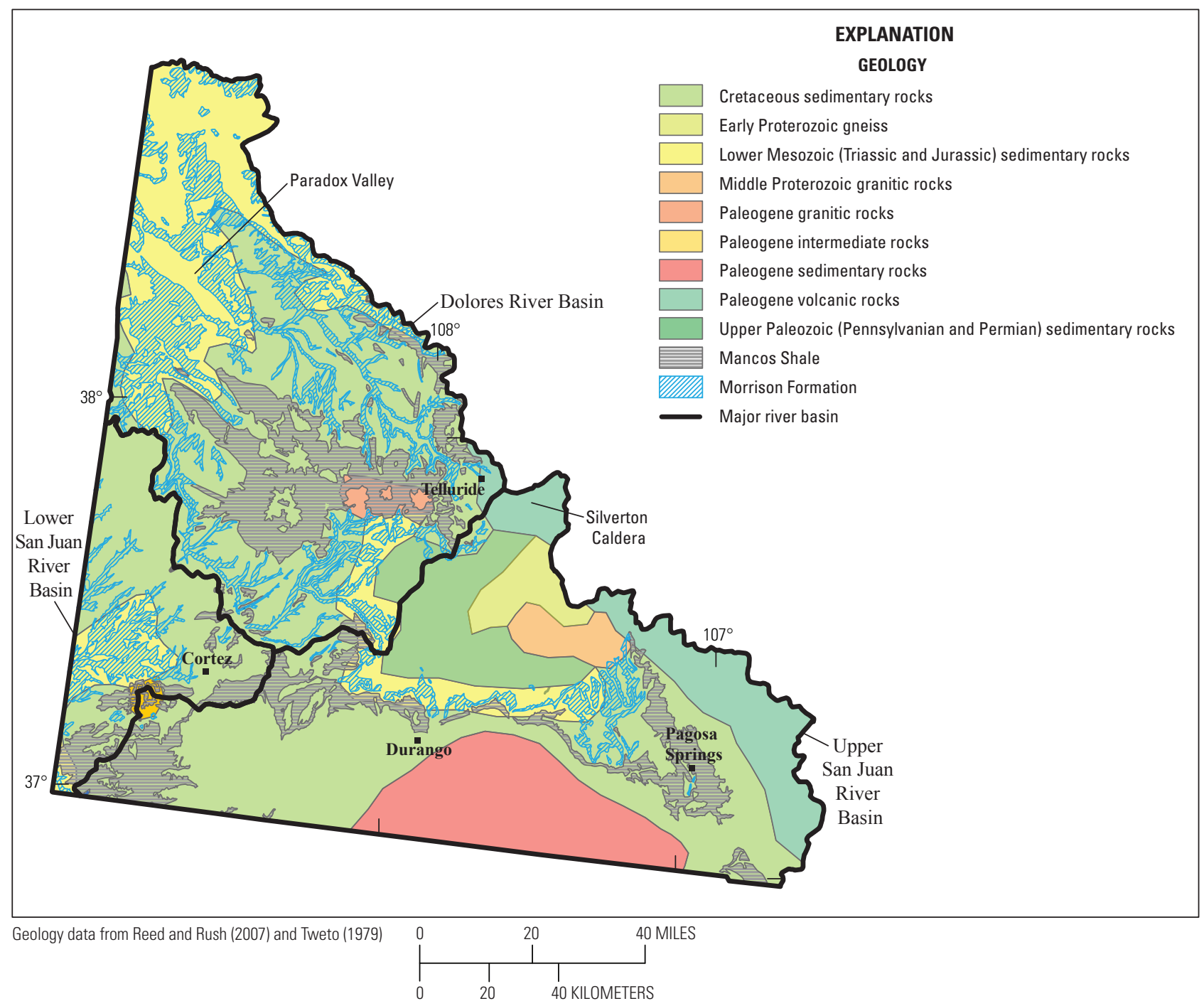

Figure 3. Map showing surface geology for southwestern Colorado.

\section{Selection and Processing of Data}

Water-quality characteristics sampled, number of samples, and site specific periods of record were summarized and plotted to choose a continuous period of time (period of analysis) in which the most data were collected at the greatest number of sites. The selected period of analysis used in this report was January 1990 through December 2005. For the purpose of this report, only stream sites with location data including the latitude and longitude were selected for analysis. In other words, water-quality data from lakes, canals, and ditches were not used, and sites without location information were excluded from the analysis.

Several quality-assurance procedures were performed prior to statistical analysis to remove suspect data. Low and high values for 190 water-quality characteristics have been established by the USEPA as an edit-checking procedure for data entered into the STOrage and RETrieval (STORET) data system (U.S. Environmental Protection Agency, 1977). These high and low values were used to determine reasonable ranges for 33 water-quality characteristics analyzed in southwestern Colorado (Appendix 1). Selected data were deleted when values exceeded reasonable ranges, for example a streamwater temperature above $300^{\circ} \mathrm{C}$. In some samples, certain trace elements had concentrations that exceeded the high values established by USEPA; however, these values were not deleted because areas with historical mining activities or with naturally high mineralization are present in the study area. There were also water-quality characteristics with zero values and no information about reporting limits. Most of the zero values were associated with nutrient and trace element results. It was not known if the zero values represented censored concentrations (that is concentrations less than the reporting limit or nondetections) or if the zero values indicated that the constituents were not analyzed. Consequently, zero concentrations for nutrients and metals were not used in the analyses presented in this report. 


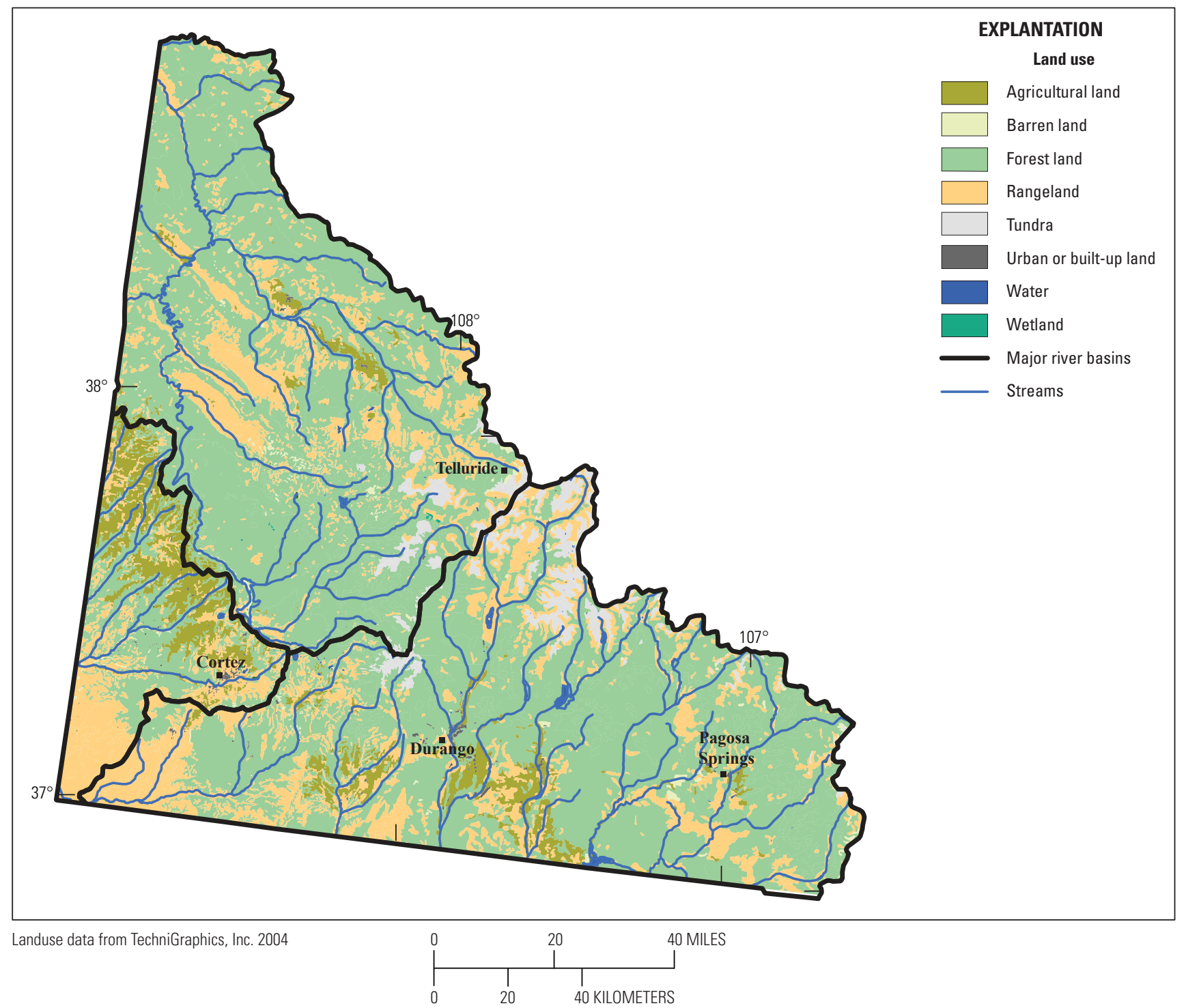

Figure 4. Map showing land use for southwestern Colorado.

Most laboratories censor data using a reporting limit that is equal to the detection limit. However, historically, the USGS National Water Quality Laboratory (NWQL) used informative censoring in an effort to provide requested information to data users and protection from false negative errors (Helsel, 2005). Numerical values were reported for concentrations greater than the detection limit yet less than the NWQL laboratory reporting level (LRL) and coded as estimated. Nondetections (that is, values less than the detection limit) were reported as less than the LRL which was generally twice the detection limit. In other words, two different reporting limits were used to report data - the detection limit and the LRL. In this way, informative censoring of the data established the reporting limit as a function of the measured concentration (Helsel, 2005). Helsel (2005) stated that informative censoring such as this invalidates the computation of percentiles (and other summary statistics) and recommended that data users recensor data before analyzing. Consequently, NWQL nondetections reported as less than the LRL were recensored and reported as less than the detection limit. Numerical values reported between the detection limit and the LRL were reported without qualification.

Reporting limits for some constituents varied substantially at some sites because samples were collected by multiple agencies for various reasons and analyzed by different laboratories. Occasionally, the reporting limit was higher than all or most of the measured concentrations at the site. For example, reporting limits for dissolved aluminum at McElmo Creek above Trail Canyon at gage site $(05 \mathrm{~L})$ ranged from $1 \mu \mathrm{g} / \mathrm{L}$ to $2,500 \mu \mathrm{g} / \mathrm{L}$. Most of the reporting limits at McElmo Creek site $05 \mathrm{~L}$ were between 30 and $500 \mu \mathrm{g} / \mathrm{L}$. A dissolved aluminum concentration of $2.9 \mu \mathrm{g} / \mathrm{L}$ was measured in 1 of the 45 samples collected (1990-2005) at the site; the remaining 44 samples were coded as not detected (less than the reporting limit). 
Water-quality criteria for select constituents were reported as table values (Colorado Department of Public Health and Environment, 2010b) and required computation based on the site-specific hardness values. Mean hardness values were used to approximate the site-specific hardness values, because limited data were available. The mean hardness value was calculated for each site where data were available and input into the corresponding constituent equations to determine the acute and(or) chronic water-quality criteria. The maximum hardness value used in computations of water-quality criteria for lead and zinc was $400 \mathrm{mg} / \mathrm{L}$ and for aluminum was $200 \mathrm{mg} / \mathrm{L}$ (Colorado Department of Public Health and Environment, 2010b).

Boxplots, scatter plots, and maps were used in this report to depict the variability of selected surface-water-quality characteristics. Boxplots were generated to show simple graphical summaries of selected water-quality characteristic values. The upper horizontal line of the box is the 75th percentile or upper quartile ( 75 percent of the data are less than this value). The horizontal line within the box represents the median value (50 percent of the data are greater than this value and 50 percent of the data are less than this value). The lower horizontal line of the box is the 25th percentile or lower quartile (25 percent of the data are less than this value). The interquartile range (IQR) contains the values between the 25 th and 75th percentiles and is the difference between the 25th and 75th percentiles. The bottom of the vertical line on the boxplot is the smallest value within 1.5 times the IQR of the box. The top of the vertical line on the boxplot is the largest value within 1.5 times the IQR of the box. Outside values are greater than 1.5 times the IQR from the box and outlier values are greater than 3 times the IQR from the box.

A trilinear diagram was constructed to classify and compare water types based on ionic composition (Hem, 1985). The most abundant cations in water generally are calcium, magnesium, sodium, and potassium; and the most abundant anions are sulfate, chloride, and bicarbonate (Bartos and Ogle, 2002). If a site had more than one sample with adequate major dissolved ion data, an average concentration for each major ion was calculated. Concentrations of major ions were converted to percent millequivalents per liter and plotted on the trilinear diagram to determine the dominant water types at selected sites.

The nonparametric Kruskal-Wallis test was used to determine whether there were statistical differences between winter (November-March) and summer (April-October) values of selected water-quality characteristics within the selected river basins in the study area (SYSTAT Software, Inc., 2004).

Nonparametric statistical tests allow the user to analyze data without assuming an underlying distribution and are not strongly affected by outliers (Helsel and Hirsch, 2002). For the purpose of this analysis, the Kruskal-Wallis null hypothesis assumed that the distribution of the data groups (that is, the water-quality characteristic values for the winter period and the summer period) were identical. The alternate hypothesis assumed that one distribution differed from the other. The probability value (p-value) is the probability of rejecting the null hypothesis if it is true. A p-value of less than or equal to 0.05 was used in this report to indicate if a statistical test was significant. A p-value less than 0.01 was considered highly significant.

\section{Computation of Summary Statistics}

Existing water quality standards from the Colorado Department of Public Health and Environment (CDPHE) Colorado Water Quality Control Commission (henceforth referred to as Commission) are defined as "the 85th percentile of the data for total ammonia, nitrate, and dissolved metals, the 50th percentile for total recoverable metals, the 15 th percentile for dissolved oxygen (DO), and the range between the 15th and 85th percentiles for $\mathrm{pH}$ " (Colorado Department of Public Health and Environment, 2010a). For purposes of comparison, the appropriate statistical values (described in the previous sentence) for each constituent discussed in this report were calculated for sites with 10 or more samples.

Methods used to calculate summary statistics including the minimum, maximum, mean, and 15th, 50th, and 85 th percentile values varied based on the amount of censored data. Summary statistics were calculated using the statistical package SYSTAT (SYSTAT Software, Inc., 2004) for waterquality characteristics such as $\mathrm{DO}, \mathrm{pH}$, water temperature, specific conductance (SC), DS, and major ions with less than 10 percent censored data. For water-quality characteristics with higher occurrences of censored values including trace elements, nutrients, and uranium, the "left-censored data analysis" interface developed by the USGS (Slack and others, 2003) for the statistical software package Spotfire S+ (TIBCO, 2008) was used to calculate summary statistics. Three different methods were used to calculate summary statistics for trace element, nutrient, and uranium concentrations based on the amount of censored data. The nonparametric KaplanMeier method modified for left-censored data, described by Helsel (2005), was used to calculate summary statistics when less than 50 percent of the data were censored. When 50 to 80 percent of the data were censored, the robust "regression on order statistics" or ROS method was used (Helsel, 2005). Finally, when more than 80 percent of the data were censored, summary statistics were reported as less than the maximum reporting limit for the water-quality characteristic at the site.

\section{Analysis of Temporal Trends}

Nonparametric statistical methods were used to test for temporal trends in various water-quality characteristic values where data were available. Specifically, the seasonal Kendall test was used to test for monotonic trends (Hirsch and Slack, 1984), or trends in one direction (upward or downward) that were not necessarily linear. The seasonal Kendall test was performed using a USGS statistical program, ESTREND (EStimate TREND) (Shertz and others, 1991) for which a 
graphical user interface was developed to be run as a "plug-in" to Spotfire S+ (Slack and others, 2003). The trend slope is a measure of the monotonic trend and an estimate of the median rate of change in water-quality characteristic values for the study period. The trend slope is an approximation of the change in constituent concentration over time which may be linear, may be in steps, or may show reversals during the study period (Schertz and others, 1991).

The initial selection criteria for site and parameter selection for analysis of temporal trends were that (1) the site had at least 10 samples, (2) the samples were evenly distributed over a 10-year period between 1990 and 2005, and (3) the sample had an associated streamflow value. Two study periods were chosen based on results from the initial selection criteria: 1993 to 2003 for field properties, major ions, and nutrients and 1991 to 2004 for trace elements. The study periods refer to calendar years that begin January 1 and end December 31 . Site and parameter pairs were further culled based on sample distribution over the study period and amount of censored data. ESTREND requires sufficient samples in the beginning and ending fifths of the study period for analysis; consequently, site and parameter combinations were eliminated that had less than two samples in the first two years and(or) last two years of the study period. Finally, site and parameter combinations were eliminated from analysis when 8 percent or more of the results were censored.

The data were analyzed using four seasons when adequate data were available. When adequate data were not available, the number of seasons analyzed was reduced. There were sufficient data to account for four seasons for all of the waterquality characteristics analyzed for trends over the 1993 to 2003 study period. There were not sufficient data to account for four seasons in the 1991 to 2004 study period for all water-quality characteristics; as a result, the trend analysis included one, two, three, and four seasons. One season referred to a calendar year; two seasons referred to a winter (November 1-March 31) and summer (April 1-October 31) season; three seasons referred to November 1-March 31 (low flow), April 1-June 30 (peak flow), and July 1-October 31 (summer rainstorms); and the four seasons were three calendar months each beginning January 1 . Within the ESTREND interface, additional selection criteria were applied to the data that ensured adequate seasonal comparisons. A subset of the data were used for the trend test that consisted of one sample for each season to account for sampling bias and ensure that each observation was independent. Results were reported for the analysis that included the most seasons.

Trends in water-quality characteristic values may be masked by variability in streamflow from year to year because of the possible correlation between the water-quality characteristics and streamflow (Hirsch and others, 1982). For the purpose of this report, characteristic values with 8 percent or less censored data were flow adjusted before analysis to remove the possible effects of streamflow variability on trends for all characteristics except $\mathrm{pH}$ and water temperature. Flow adjustment of concentrations is a parametric procedure that assumes normality and constant variance in the distributions of the concentration and streamflow data. To meet these assumptions, both parameters were log transformed. Flow-adjusted concentrations are the residuals of the regression of the logtransformed concentrations on log-transformed streamflow (Smith and others, 1982). The regression is of the form (model 12, Schertz and others, 1991):

$$
\text { In } \hat{C}=\hat{b}_{0}+\hat{b}_{1} \ln Q+\hat{b}_{2}(\ln Q)^{2}
$$

$\hat{C} \quad$ is the estimate concentration;

$Q \quad$ is the streamflow in cubic feet per second;

ln is the natural logarithm; and

$\hat{b}_{0}, \hat{b}_{1}$, and $\hat{b}_{2}$ are the parameters estimated from the regression procedure.

Streamflow data were often not associated with samples. For a site colocated with a USGS streamflow-gaging station, the corresponding mean daily streamflow value from the USGS streamflow-gaging station was used to approximate the streamflow for each sample (U.S. Geological Survey, 2011). This was done to increase the number of sites/water-quality characteristics that met selection criteria for trend analysis. Instantaneous streamflow measurements are usually made by the USGS when water-quality samples are collected (Rantz and others, 1982). As a result, most samples collected by the USGS have instantaneous streamflow data associated with them. For sites sampled by agencies other than the USGS that had streamflow data associated with samples, the streamflows were assumed to be instantaneous values.

Trend results from the seasonal Kendall test were reported in terms of the percent change relative to the unadjusted median value of the data used for the trend analysis (henceforth referred to as typical value). The trend analysis, however, used flow-adjusted concentrations. The calculations were performed within the ESTREND program. ESTREND calculates an adjusted p-value that takes into account that seasons may be serially correlated. The p-value, adjusted for serial dependence, was an estimate of the probability that there was no change in concentration or value over time.

\section{Surface-Water Quality in Southwestern Colorado}

The spatial and temporal distribution of $\mathrm{DO}, \mathrm{pH}$, water temperature, DS, major ions, selected trace elements, nutrients, and uranium data are discussed in this section and its subsections. These water-quality characteristics are described spatially by location within the Dolores River Basin, Upper SJRB, and Lower SJRB (fig. 1). Site identification numbers, names, and location information for sites used in the analyses are shown in table 1. In order to provide an overview of existing surface-water water-quality conditions in each river basin, selected physical and chemical water-quality characteristics were compared to State water-quality standards. The temporal 
Table 1. List of sites and site location information, southwestern Colorado, 1990-2005.

[Site ID, identification number shown in figure 1; Database ID, data repository identification number (http://rmgsc.cr.usgs.gov/cwqdr/Southwest/index.shtml); LatitudeDD, latitude in decimal degrees; LongitudeDD, longitude in decimal degrees; USGS, U.S. Geological Survey; WWTP, wastewater treatment plant]

\begin{tabular}{|c|c|c|c|c|c|}
\hline Site ID & Database ID & Site name & Subbasin name & LatitudeDD & LongitudeDD \\
\hline \multicolumn{6}{|c|}{ Dolores River Basin } \\
\hline 01D & 10784R & Coal Creek at FR 535 below Lizard Head Wilderness Area & Upper Dolores & 37.790 & -108.018 \\
\hline 03D & 10718 & Dolores River above Horse Creek & Upper Dolores & 37.702 & -108.031 \\
\hline $04 \mathrm{D}$ & 10780 & Silver Creek at Highway 145 & Upper Dolores & 37.683 & -108.033 \\
\hline 07D & 10770 & West Dolores River near Stoner at Highway 145 & Upper Dolores & 37.588 & -108.357 \\
\hline 08D & $10901 \mathrm{~A}$ & Lost Canyon Creek near Dolores & Upper Dolores & 37.446 & -108.469 \\
\hline 09D & 09166950 & Lost Canyon Creek near Dolores & Upper Dolores & 37.446 & -108.469 \\
\hline $10 \mathrm{D}$ & 09166500 & Dolores River at Dolores & Upper Dolores & 37.472 & -108.498 \\
\hline $14 \mathrm{D}$ & 09168730 & Dolores River near Slick Rock & Upper Dolores & 38.044 & -108.905 \\
\hline $15 \mathrm{D}$ & 000085 & Dolores River above confluence with San Miguel River & Upper Dolores & 38.300 & -108.867 \\
\hline $16 \mathrm{D}$ & 09169500 & Dolores River at Bedrock & Upper Dolores & 38.310 & -108.885 \\
\hline $17 \mathrm{D}$ & 4958900 & Lasal Creek at Utah-Colorado State Line & Upper Dolores & 38.328 & -109.060 \\
\hline $18 \mathrm{D}$ & 09170800 & West Paradox Creek above Bedrock & Upper Dolores & 38.332 & -108.900 \\
\hline 19D & 09171100 & Dolores River near Bedrock & Upper Dolores & 38.357 & -108.833 \\
\hline $20 \mathrm{D}$ & 10818 & San Miguel River above Marshall Creek & San Miguel & 37.931 & -107.779 \\
\hline $21 \mathrm{D}$ & $\mathrm{BC} 1$ & (2), Bear Creek & San Miguel & 37.935 & -107.804 \\
\hline $22 \mathrm{D}$ & 1 & Upstream, SMIG above Bear & San Miguel & 37.935 & -107.804 \\
\hline $23 \mathrm{D}$ & C1-SW & (7), Coronet & San Miguel & 37.937 & -107.820 \\
\hline $30 \mathrm{D}$ & 10860 & McKenzie Creek at mouth above confluence with San Miguel River & San Miguel & 38.126 & -108.208 \\
\hline $31 \mathrm{D}$ & 09174600 & San Miguel River at Brooks Bridge near Nucla & San Miguel & 38.244 & -108.502 \\
\hline $32 \mathrm{D}$ & 10831 & Naturita Creek at Naturita & San Miguel & 38.218 & -108.545 \\
\hline $33 \mathrm{D}$ & 09177000 & San Miguel River at Uravan & San Miguel & 38.357 & -108.713 \\
\hline $34 \mathrm{D}$ & 000084 & San Miguel River at confluence with Dolores River & San Miguel & 38.409 & -108.755 \\
\hline $35 \mathrm{D}$ & 10903 & Salt Creek at Highway 141 & Lower Dolores & 38.562 & -108.921 \\
\hline $36 \mathrm{D}$ & 10915 & West Creek in Unaweep Canyon & Lower Dolores & 38.773 & -108.881 \\
\hline $37 \mathrm{D}$ & 000061 & Dolores River at Gateway & Lower Dolores & 38.667 & -109.017 \\
\hline \multicolumn{6}{|c|}{ Upper San Juan River Basin } \\
\hline $01 \mathrm{~A}$ & A09 & North Fork above Cal. Gulch & Animas & 37.933 & -107.569 \\
\hline $02 \mathrm{~A}$ & A33 & Animas River at Eureka & Animas & 37.879 & -107.565 \\
\hline $03 \mathrm{~A}$ & A39 & Eureka below Ben Franklin & Animas & 37.892 & -107.602 \\
\hline $04 \mathrm{~A}$ & A53 & Animas River at Howardsville & Animas & 37.833 & -107.599 \\
\hline $05 \mathrm{~A}$ & A60 & Animas River downstream from Arrastra Gulch & Animas & 37.827 & -107.626 \\
\hline $06 \mathrm{~A}$ & AN68 & Animas River at USGS gaging station above 14th Street & Animas & 37.828 & -107.591 \\
\hline
\end{tabular}


Table 1. List of sites and site location information, southwestern Colorado, 1990-2005.-Continued

[Site ID, identification number shown in figure 1; Database ID, data repository identification number (http://rmgsc.cr.usgs.gov/cwqdr/Southwest/index.shtml); LatitudeDD, latitude in decimal degrees; LongitudeDD, longitude in decimal degrees; USGS, U.S. Geological Survey; WWTP, wastewater treatment plant]

\begin{tabular}{|c|c|c|c|c|c|}
\hline Site ID & Database ID & Site name & Subbasin name & LatitudeDD & LongitudeDD \\
\hline \multicolumn{6}{|c|}{ Upper San Juan River Basin-Continued } \\
\hline $07 \mathrm{~A}$ & A68 & Animas River at Silverton & Animas & 37.811 & -107.659 \\
\hline 09A & $\mathrm{CC} 18$ & $\begin{array}{l}\text { North Fork Cement Creek upstream from Gold King mine, \#7 level } \\
\text { (AMLI mine \# 103) }\end{array}$ & Animas & 37.896 & -107.630 \\
\hline $10 \mathrm{~A}$ & $\mathrm{CC} 32$ & South Fork Cement Creek downstream from Velocity Lake & Animas & 37.869 & -107.644 \\
\hline $12 \mathrm{~A}$ & $\mathrm{CC} 23$ & Prospect Gulch upstream from Red Spring & Animas & 37.883 & -107.669 \\
\hline $13 \mathrm{~A}$ & $\mathrm{C} 31$ & Cement Creek at Fairview Gulch Bridge & Animas & 37.875 & -107.671 \\
\hline $14 \mathrm{~A}$ & $\mathrm{CC} 14$ & Minnesota Gulch near mouth & Animas & 37.863 & -107.676 \\
\hline $15 \mathrm{~A}$ & $\mathrm{CC} 20$ & Porcupine Gulch upstream from mines & Animas & 37.861 & -107.684 \\
\hline $19 \mathrm{~A}$ & CEM48 & Cement Creek at USGS gaging station & Animas & 37.820 & -107.663 \\
\hline $20 \mathrm{~A}$ & M02 & Mineral Creek near headwaters & Animas & 37.900 & -107.711 \\
\hline $21 \mathrm{~A}$ & M02A & $\begin{array}{l}\text { Highway } 550 \text { drainage ditch above M01 confluence-east side of } \\
\text { Highway } 550\end{array}$ & Animas & 37.895 & -107.714 \\
\hline $22 \mathrm{~A}$ & M07 & Mineral Creek at Chattanooga & Animas & 37.874 & -107.724 \\
\hline $23 \mathrm{~A}$ & M13 & Mineral Creek just below confluence with Browns Gulch & Animas & 37.854 & -107.726 \\
\hline $24 \mathrm{~A}$ & M12 & Browns Gulch above confluence with Mineral Creek & Animas & 37.857 & -107.723 \\
\hline $25 \mathrm{~A}$ & M13A & Mineral Creek at Burro Bridge & Animas & 37.851 & -107.725 \\
\hline $26 \mathrm{~A}$ & 375028107455801 & A43 Paradise Basin above confluence above mines & Animas & 37.841 & -107.767 \\
\hline $29 \mathrm{~A}$ & M20 & Middle Fork Mineral Creek above Bonner Mine & Animas & 37.846 & -107.741 \\
\hline $30 \mathrm{~A}$ & M27 & Mineral Creek above confluence with South Fork Mineral Creek & Animas & 37.822 & -107.719 \\
\hline $31 \mathrm{~A}$ & 09359010 & Mineral Creek at Silverton (USGS) & Animas & 37.803 & -107.673 \\
\hline $32 \mathrm{~A}$ & M34 & Mineral Creek at Silverton & Animas & 37.803 & -107.672 \\
\hline $33 \mathrm{~A}$ & 09359020 & Animas River below Silverton & Animas & 37.790 & -107.668 \\
\hline $34 \mathrm{~A}$ & AN72 & Animas River at USGS gaging station just above railroad bridge & Animas & 37.790 & -107.667 \\
\hline $35 \mathrm{~A}$ & A72 & Animas River downstream from Silverton & Animas & 37.790 & -107.667 \\
\hline $36 \mathrm{~A}$ & 000082 & Animas River near Silverton & Animas & 37.792 & -107.683 \\
\hline $37 \mathrm{~A}$ & 374248107323601 & Big Eldorado inflow & Animas & 37.713 & -107.544 \\
\hline $38 \mathrm{~A}$ & 374248107324501 & Little Eldorado inflow & Animas & 37.713 & -107.546 \\
\hline $39 \mathrm{~A}$ & 9445 & Cascade Creek at Highway 550 & Animas & 37.659 & -107.810 \\
\hline $40 \mathrm{~A}$ & 000081 & Animas River above Durango & Animas & 37.457 & -107.798 \\
\hline $41 \mathrm{~A}$ & DRALP003 & Animas at Durango Mall & Animas & 37.419 & -107.819 \\
\hline $42 \mathrm{~A}$ & 89 & Trimble Lane Bridge & Animas & 37.385 & -107.836 \\
\hline $43 \mathrm{~A}$ & 9440 & Falls Creek at 0.65 Road & Animas & 37.378 & -107.868 \\
\hline $44 \mathrm{~A}$ & 135 & Animas at 32nd Street Bridge & Animas & 37.300 & -107.868 \\
\hline $45 \mathrm{~A}$ & 09361500 & Animas River at Durango (USGS) & Animas & 37.279 & -107.880 \\
\hline $46 \mathrm{~A}$ & 9420 & Animas River at Durango & Animas & 37.268 & -107.886 \\
\hline $47 \mathrm{~A}$ & DRALPLC2 & Lightner Creek at mouth at Durango & Animas & 37.268 & -107.887 \\
\hline $48 \mathrm{~A}$ & DRALP001 & DRALP001 & Animas & 37.257 & -107.883 \\
\hline
\end{tabular}




\section{Assessment of Historical Surface-Water Quality Data in Southwestern Colorado, 1990-2005}

Table 1. List of sites and site location information, southwestern Colorado, 1990-2005.-Continued

[Site ID, identification number shown in figure 1; Database ID, data repository identification number (http://rmgsc.cr.usgs.gov/cwqdr/Southwest/index.shtml); LatitudeDD, latitude in decimal degrees; LongitudeDD, longitude in decimal degrees; USGS, U.S. Geological Survey; WWTP, wastewater treatment plant]

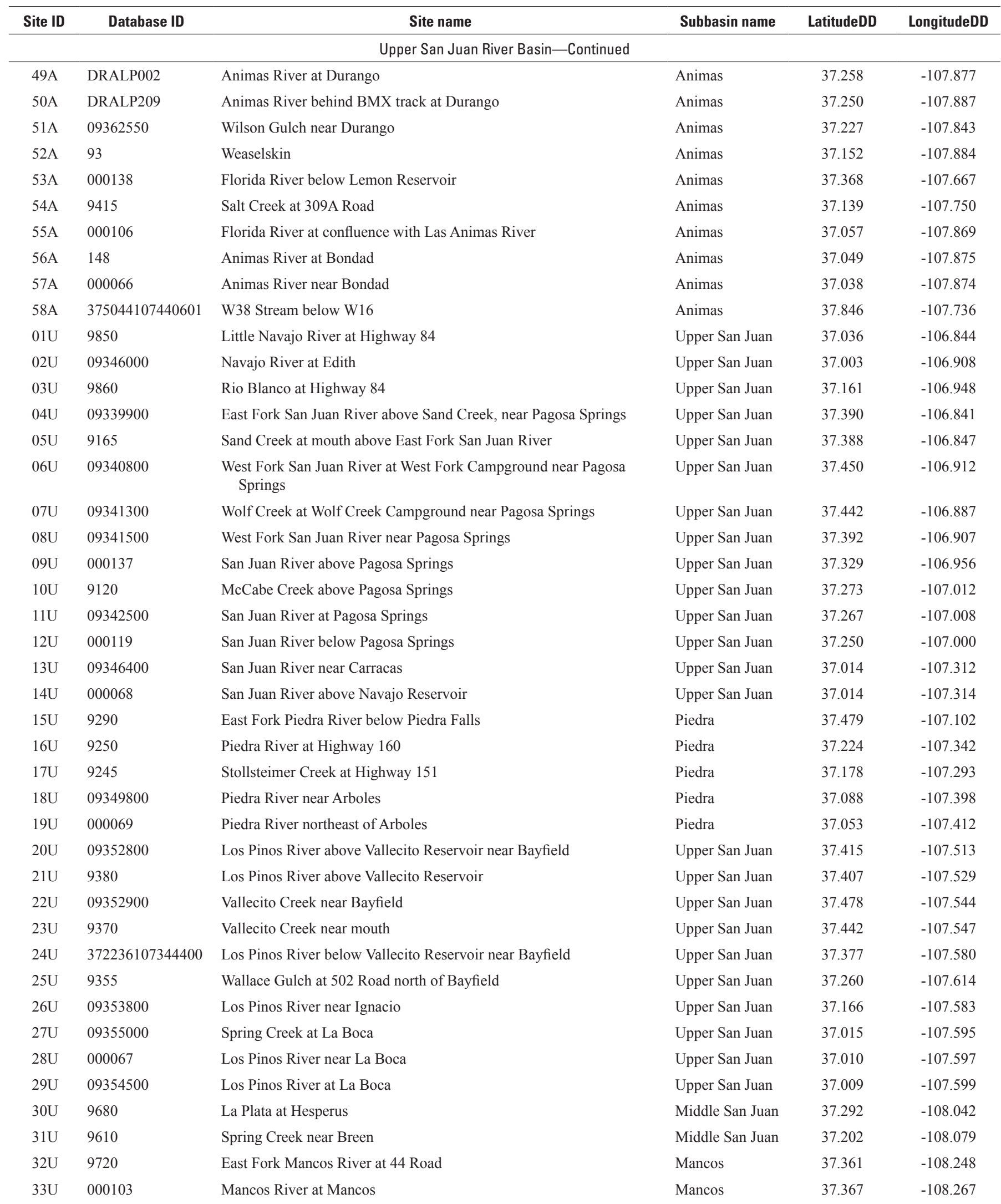


Table 1. List of sites and site location information, southwestern Colorado, 1990-2005.-Continued

[Site ID, identification number shown in figure 1; Database ID, data repository identification number (http://rmgsc.cr.usgs.gov/cwqdr/Southwest/index.shtml); LatitudeDD, latitude in decimal degrees; LongitudeDD, longitude in decimal degrees; USGS, U.S. Geological Survey; WWTP, wastewater treatment plant]

\begin{tabular}{|c|c|c|c|c|c|}
\hline Site ID & Database ID & Site name & Subbasin name & LatitudeDD & LongitudeDD \\
\hline \multicolumn{6}{|c|}{ Upper San Juan River Basin_-Continued } \\
\hline $34 \mathrm{U}$ & 9715 & Chicken Creek at Mancos & Mancos & 37.345 & -108.314 \\
\hline $36 \mathrm{U}$ & 09371002 & Navajo Wash near Towaoc & Mancos & 37.201 & -108.698 \\
\hline \multicolumn{6}{|c|}{ Lower San Juan River Basin } \\
\hline $03 \mathrm{~L}$ & 09371500 & McElmo Creek near Cortez & McElmo & 37.323 & -108.673 \\
\hline $04 \mathrm{~L}$ & 09371520 & McElmo Creek above Trail Canyon near Cortez & McElmo & 37.327 & -108.701 \\
\hline $05 \mathrm{~L}$ & 9871 & McElmo Creek above Trail Canyon at gage & McElmo & 37.328 & -108.702 \\
\hline $06 \mathrm{~L}$ & 09372000 & McElmo Creek near Colorado-Utah State Line & McElmo & 37.324 & -109.016 \\
\hline
\end{tabular}

distribution of water-quality characteristics typically was discussed in reference to seasonal differences or changes in values over time (trends) if adequate data were available. Temporal trend analyses were done for sites meeting the criteria described in the "Analysis of Temporal Trends" section of the report. Trend analyses for $\mathrm{DO}, \mathrm{pH}$, water temperature, $\mathrm{SC}$, DS, chloride, and sulfate data were done for the period January 1993 through December 2003 and for selected trace metals data for the period January 1991 through December 2004.

Urban and agricultural activities can often increase nutrient and sediment loading to streams, increase stream-water temperatures, and alter channel geomorphology which may result in increased growth of aquatic organisms such as algae and loss of aquatic habitat. Photosynthesis by aquatic organisms uses up hydrogen molecules causing the concentration of hydrogen to decrease and therefore the $\mathrm{pH}$ to increase; whereas, respiration and decay processes lower $\mathrm{pH}$ (Washington State Department of Ecology, 1994). In aquatic systems, these processes (photosynthesis, respiration, and decay) can produce diurnal fluctuations in $\mathrm{pH}$ and $\mathrm{DO}$ (Hem, 1985). Kuwabara and others (2003) noted that, for the most part, the amplitudes of diurnal $\mathrm{pH}$ cycles increased (that is $\mathrm{pH}$ values were higher during the daylight hours and lower during the night) with increasing biomass. In turn, changes in $\mathrm{pH}$ affect sorption and precipitation characteristics of metals in water.

\section{Dissolved Oxygen}

Overall, streams throughout the study area were well oxygenated. Median DO concentrations generally ranged from 8 to $10 \mathrm{mg} / \mathrm{L}$ in surface water (table 2). Instantaneous DO concentrations ranged from 0 to $23 \mathrm{mg} / \mathrm{L}$. Dissolved oxygen concentrations in surface water in the study area were generally lowest from July through September and highest from November through February corresponding to seasonal changes in air and water temperature. The solubility of oxygen increases as temperature decreases; as a result, DO concentrations would be expected to be higher during the winter months when temperatures are cooler and lower during the summer months when temperatures are warmer.

Adequate DO concentrations in surface water are required for healthy aquatic communities. The existing water quality for DO was defined by the Commission as the 15th percentile concentration. The Commission established physical and biological water-quality standards for DO in streams in southwestern Colorado that varied from $3.0 \mathrm{mg} / \mathrm{L}$ in selected segments of the Animas and Florida River Basin (Colorado Department of Public Health and Environment, 2010a) to $7.0 \mathrm{mg} / \mathrm{L}$ during periods of spawning in certain designated cold water segments (Colorado Department of Public Health and Environment, 2010b) of the study area. For most segments, the standard was either 5 or $6 \mathrm{mg} / \mathrm{L}$ (Colorado Department of Public Health and Environment, 2010a). The 15th percentile DO value for most sites was greater than $7 \mathrm{mg} / \mathrm{L}$.

Dolores River Basin.-Dissolved oxygen data were analyzed at 25 sites. The 15 th percentile concentrations ranged from 5.0 to $8.9 \mathrm{mg} / \mathrm{L}$ (table 2). The lowest 15 th percentile DO concentrations, values less than $6 \mathrm{mg} / \mathrm{L}$, occurred at several sites in the upper San Miguel River Basin near Telluride and at one site on Salt Creek (table 2). Sufficient data were not available to calculate temporal trends.

Upper San Juan River Basin.-Dissolved oxygen data were analyzed at 40 sites. The 15 th percentile concentrations ranged from 0.1 to $9.7 \mathrm{mg} / \mathrm{L}$ (table 2). Only one stream site, South Fork Cement Creek downstream from Velocity Lake (10A), had a 15th percentile DO concentration less than $5 \mathrm{mg} / \mathrm{L}$ (table 2). This site was located in the upper Animas River Basin in the vicinity of Silverton. Most other sites had 15th percentile DO concentrations that exceeded $7 \mathrm{mg} / \mathrm{L}$. 
Table 2. Statistical summary for dissolved oxygen, $\mathrm{pH}$, and water-temperature data for sites with 10 or more samples in the Dolores, Upper San Juan, and Lower San Juan River Basins, southwestern Colorado, 1990-2005.

[Site ID, site identification number shown on figure 1; No., number of samples; Min, minimum value; Max, maximum value; --, not applicable; gray shaded columns indicate statistics that were used for comparison to State water-quality standards and values shown in red represent instances when State water-quality standards were not met; WWTP, wastewater treatment plant]

\begin{tabular}{|c|c|c|c|c|c|c|c|c|}
\hline \multirow{2}{*}{$\begin{array}{l}\text { Site } \\
\text { ID }\end{array}$} & \multirow{2}{*}{ Site name } & \multicolumn{7}{|c|}{ Dissolved oxygen, milligrams per liter } \\
\hline & & No. & Min & Max & Mean & 15 & 50 & 85 \\
\hline \multicolumn{9}{|c|}{ Dolores River Basin } \\
\hline $01 \mathrm{D}$ & Coal Creek at FR 535 below Lizard Head Wilderness Area & -- & -- & -- & -- & -- & -- & -- \\
\hline 03D & Dolores River above Horse Creek & 15 & 8.3 & 11.6 & 9.8 & 8.7 & 9.9 & 10.8 \\
\hline $04 \mathrm{D}$ & Silver Creek at Highway 145 & 38 & 7.7 & 15.6 & 10.8 & 8.8 & 10.5 & 12.8 \\
\hline $05 \mathrm{D}$ & Dolores River below Rico & 42 & 6.6 & 15.2 & 10.1 & 8.2 & 9.9 & 11.9 \\
\hline $08 \mathrm{D}$ & Lost Canyon Creek near Dolores & 12 & 6.3 & 11.3 & 9.0 & 6.3 & 9.7 & 10.7 \\
\hline 09D & Lost Canyon Creek near Dolores & -- & -- & -- & -- & -- & -- & -- \\
\hline $10 \mathrm{D}$ & Dolores River at Dolores & -- & -- & -- & -- & -- & -- & -- \\
\hline $12 \mathrm{D}$ & Dolores River near town of Dolores & 13 & 8.2 & 12.0 & 10.4 & 8.7 & 10.6 & 11.8 \\
\hline $13 \mathrm{D}$ & Dolores River at Dolores above Mcphee Reservoir & 25 & 6.0 & 13.7 & 9.5 & 7.1 & 9.4 & 11.5 \\
\hline $14 \mathrm{D}$ & Dolores River near Slick Rock & -- & -- & -- & -- & -- & -- & -- \\
\hline $20 \mathrm{D}$ & San Miguel River above Marshall Creek & 11 & 8.4 & 13.7 & 9.6 & 8.5 & 9.0 & 10.8 \\
\hline $21 \mathrm{D}$ & (2), Bear Creek & 11 & 0.4 & 13.8 & 9.5 & 5.7 & 10.1 & 13.2 \\
\hline $22 \mathrm{D}$ & Upstream, SMIG above Bear & 11 & 0.4 & 13.3 & 9.4 & 6.1 & 9.8 & 12.9 \\
\hline $23 \mathrm{D}$ & (7), Coronet & 11 & 0.4 & 13.2 & 9.1 & 5.7 & 9.4 & 12.7 \\
\hline $24 \mathrm{D}$ & Downstream, SMMAHONEY & 11 & 0.4 & 13.2 & 9.0 & 5.6 & 9.5 & 12.2 \\
\hline $25 \mathrm{D}$ & San Miguel River at Society Turn & 70 & 7.1 & 14.6 & 9.4 & 7.9 & 9.1 & 10.6 \\
\hline $26 \mathrm{D}$ & South Fork San Miguel River near mouth & 24 & 8.1 & 12.4 & 9.8 & 8.5 & 9.5 & 11.8 \\
\hline $27 \mathrm{D}$ & Howard Fork San Miguel River at Ophir & 17 & 8.1 & 11.7 & 9.9 & 8.9 & 9.8 & 11.0 \\
\hline $28 \mathrm{D}$ & San Miguel River near Placerville & -- & -- & -- & -- & -- & -- & -- \\
\hline $29 \mathrm{D}$ & San Miguel River near Norwood & 33 & 6.8 & 14.0 & 9.9 & 8.2 & 9.6 & 12.7 \\
\hline $30 \mathrm{D}$ & McKenzie Creek at mouth above confluence with San Miguel River & 17 & 5.2 & 10.2 & 8.0 & 6.6 & 8.1 & 9.4 \\
\hline $31 \mathrm{D}$ & San Miguel River at Brooks Bridge near Nucla & -- & -- & -- & -- & -- & -- & -- \\
\hline $32 \mathrm{D}$ & Naturita Creek at Naturita & 18 & 6.5 & 13.8 & 9.8 & 7.7 & 8.8 & 12.8 \\
\hline $06 \mathrm{~A}$ & Animas River at USGS gaging station above 14th Street & -- & -- & -- & -- & -- & -- & -- \\
\hline 07A & Animas River at Silverton & 51 & 5.4 & 10.6 & 8.4 & 6.8 & 8.5 & 9.8 \\
\hline 08A & Animas River at Silverton & -- & -- & -- & -- & -- & -- & -- \\
\hline $09 \mathrm{~A}$ & North Fork Cement Creek upstream from Gold King mine, \#7 level (AMLI mine \# 103) & -- & -- & -- & -- & -- & -- & -- \\
\hline $10 \mathrm{~A}$ & South Fork Cement Creek downstream from Velocity Lake & 10 & 0.0 & 8.1 & 1.1 & 0.1 & 0.3 & 1.2 \\
\hline $11 \mathrm{~A}$ & South Fork Cement Creek downstream from Big Colorado mine (AMLI mine \# 150) & 10 & 7.0 & 11.0 & 8.5 & 7.4 & 8.6 & 9.3 \\
\hline $13 \mathrm{~A}$ & Cement Creek at Fairview Gulch Bridge & -- & -- & -- & -- & -- & -- & -- \\
\hline $15 \mathrm{~A}$ & Porcupine Gulch upstream from mines & -- & -- & -- & -- & -- & -- & -- \\
\hline $16 \mathrm{~A}$ & Niagara Gulch near mouth & -- & -- & -- & -- & -- & -- & -- \\
\hline $17 \mathrm{~A}$ & Cement Creek at Silverton & -- & -- & -- & -- & -- & -- & -- \\
\hline $18 \mathrm{~A}$ & Cement Creek at Silverton & 51 & 5.6 & 13.9 & 8.4 & 7.0 & 8.3 & 9.6 \\
\hline $19 \mathrm{~A}$ & Cement Creek at USGS gaging station & -- & -- & -- & -- & -- & -- & -- \\
\hline $21 \mathrm{~A}$ & Highway 550 drainage ditch above M01 confluence-east side of Highway 550 & -- & -- & -- & -- & -- & -- & -- \\
\hline $23 \mathrm{~A}$ & Mineral Creek just below confluence with Browns Gulch & -- & -- & -- & -- & -- & -- & -- \\
\hline $25 \mathrm{~A}$ & Mineral at Burro Bridge & -- & -- & -- & -- & -- & -- & -- \\
\hline $31 \mathrm{~A}$ & Mineral Creek at Silverton & -- & -- & -- & -- & -- & -- & -- \\
\hline
\end{tabular}


Table 2. Statistical summary for dissolved oxygen, $\mathrm{pH}$, and water-temperature data for sites with 10 or more samples in the Dolores, Upper San Juan, and Lower San Juan River Basins, southwestern Colorado, 1990-2005. - Continued

[Site ID, site identification number shown on figure 1; No., number of samples; Min, minimum value; Max, maximum value; --, not applicable; gray shaded columns indicate statistics that were used for comparison to State water-quality standards and values shown in red represent instances when State water-quality standards were not met; WWTP, wastewater treatment plant]

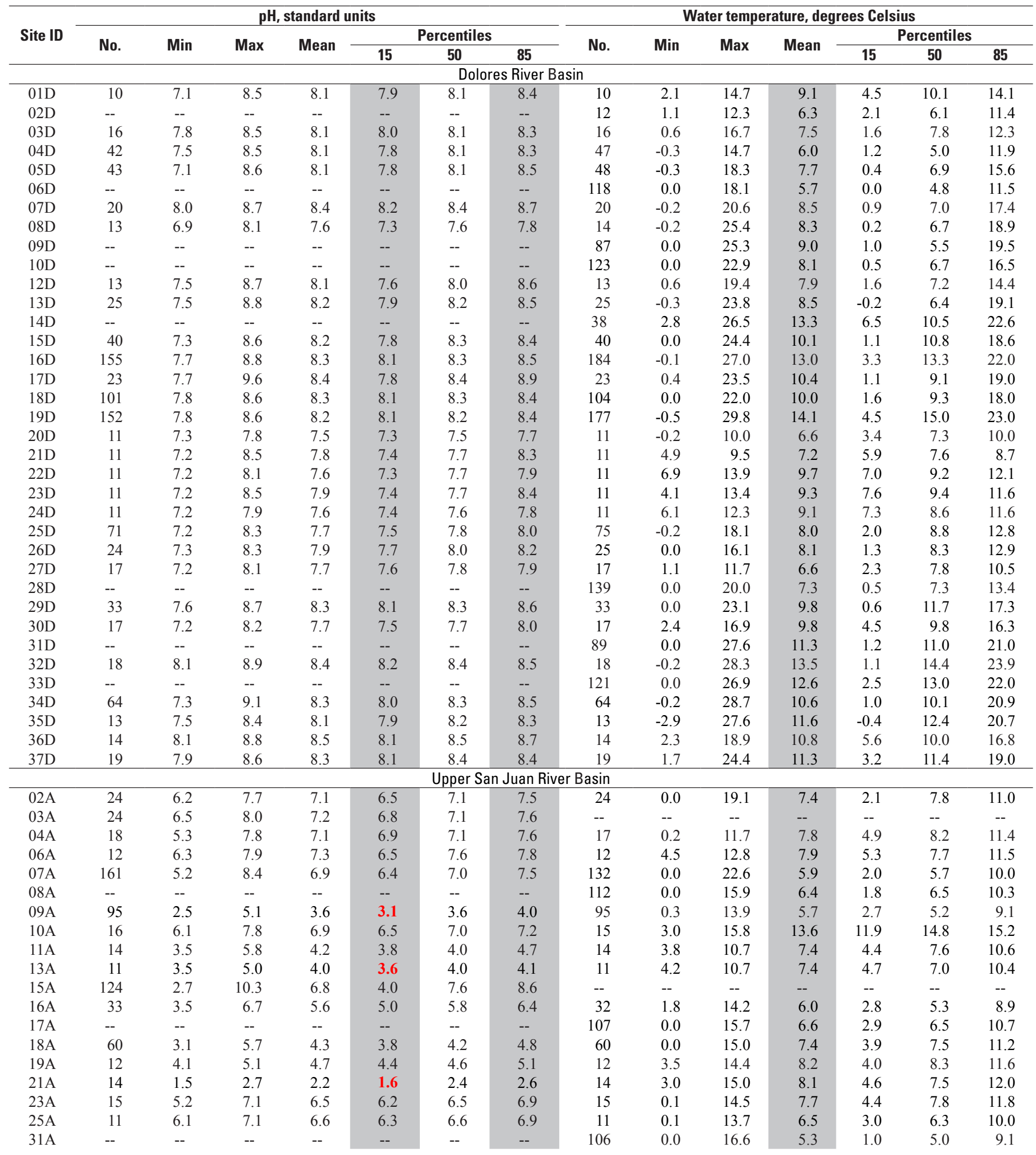


Table 2. Statistical summary for dissolved oxygen, $\mathrm{pH}$, and water-temperature data for sites with 10 or more samples in the Dolores, Upper San Juan, and Lower San Juan River Basins, southwestern Colorado, 1990-2005._Continued

[Site ID, site identification number shown on figure 1; No., number of samples; Min, minimum value; Max, maximum value; --, not applicable; gray shaded columns indicate statistics that were used for comparison to State water-quality standards and values shown in red represent instances when State water-quality standards were not met; WWTP, wastewater treatment plant]

\begin{tabular}{|c|c|c|c|c|c|c|c|c|}
\hline \multirow{3}{*}{$\begin{array}{c}\text { Site } \\
\text { ID }\end{array}$} & \multirow{3}{*}{ Site name } & \multicolumn{7}{|c|}{ Dissolved oxygen, milligrams per liter } \\
\hline & & \multirow{2}{*}{ No. } & \multirow{2}{*}{ Min } & \multirow{2}{*}{ Max } & \multirow{2}{*}{ Mean } & \multicolumn{3}{|c|}{ Percentiles } \\
\hline & & & & & & 15 & 50 & 85 \\
\hline \multicolumn{9}{|c|}{ Upper San Juan River Basin-Continued } \\
\hline $32 \mathrm{~A}$ & Mineral Creek at Silverton & 54 & 5.5 & 12.5 & 8.4 & 6.9 & 8.3 & 9.8 \\
\hline $33 \mathrm{~A}$ & Animas River below Silverton & 83 & 7.5 & 11.8 & 9.7 & 8.1 & 9.6 & 11.1 \\
\hline $34 \mathrm{~A}$ & Animas River at USGS gaging station just above railroad bridge & -- & -- & -- & -- & -- & -- & -- \\
\hline $35 \mathrm{~A}$ & Animas River downstream from Silverton & 55 & 5.4 & 11.8 & 9.0 & 7.5 & 9.0 & 10.6 \\
\hline $36 \mathrm{~A}$ & Animas River near Silverton & 74 & 6.3 & 12.8 & 9.3 & 8.0 & 9.2 & 10.9 \\
\hline $37 \mathrm{~A}$ & Big Eldorado inflow & -- & -- & -- & -- & -- & -- & -- \\
\hline $38 \mathrm{~A}$ & Little Eldorado inflow & -- & -- & -- & -- & -- & -- & -- \\
\hline $39 \mathrm{~A}$ & Cascade Creek at Highway 550 & 15 & 7.3 & 14.2 & 9.7 & 8.0 & 9.4 & 11.2 \\
\hline $40 \mathrm{~A}$ & Animas River above Durango & 35 & 8.2 & 12.4 & 10.6 & 9.1 & 10.8 & 12.0 \\
\hline $41 \mathrm{~A}$ & Animas at Durango Mall & -- & -- & -- & -- & -- & -- & -- \\
\hline $42 \mathrm{~A}$ & Trimble Lane Bridge & -- & -- & -- & -- & -- & -- & -- \\
\hline $43 \mathrm{~A}$ & Falls Creek at 0.65 Road & 12 & 6.4 & 12.6 & 10.0 & 8.0 & 10.3 & 11.9 \\
\hline $44 \mathrm{~A}$ & Animas at 32nd Street Bridge & -- & -- & -- & -- & -- & -- & -- \\
\hline $45 \mathrm{~A}$ & Animas River at Durango & -- & -- & -- & -- & -- & -- & -- \\
\hline $46 \mathrm{~A}$ & Animas River at Durango & 29 & 6.4 & 15.6 & 9.6 & 7.7 & 9.5 & 11.2 \\
\hline $47 \mathrm{~A}$ & Lightner Creek at mouth at Durango & -- & -- & -- & -- & -- & -- & -- \\
\hline $48 \mathrm{~A}$ & DRALP001 & -- & -- & -- & -- & -- & -- & -- \\
\hline $49 \mathrm{~A}$ & Animas River at Durango & -- & -- & -- & -- & -- & -- & -- \\
\hline $50 \mathrm{~A}$ & Animas River behind BMX track at Durango & -- & -- & -- & -- & -- & -- & -- \\
\hline $51 \mathrm{~A}$ & Wilson Gulch near Durango & -- & -- & -- & -- & -- & -- & -- \\
\hline $52 \mathrm{~A}$ & Weaselskin & -- & -- & -- & -- & -- & -- & -- \\
\hline $53 \mathrm{~A}$ & Florida River below Lemon Reservoir & 24 & 7.4 & 11.9 & 9.8 & 8.4 & 9.9 & 11.1 \\
\hline $54 \mathrm{~A}$ & Salt Creek at 309A Road & 15 & 5.6 & 12.3 & 8.7 & 5.8 & 9.2 & 11.8 \\
\hline $55 \mathrm{~A}$ & Florida River at confluence with Las Animas River & 15 & 8.3 & 12.2 & 10.2 & 8.4 & 9.9 & 11.9 \\
\hline $56 \mathrm{~A}$ & Animas River at Bondad & -- & -- & -- & -- & -- & -- & -- \\
\hline $57 \mathrm{~A}$ & Animas River near Bondad & -- & -- & -- & -- & -- & -- & -- \\
\hline $01 \mathrm{U}$ & Little Navajo River at Highway 84 & 16 & 6.6 & 16.1 & 9.5 & 6.9 & 9.8 & 10.8 \\
\hline $02 \mathrm{U}$ & Navajo River at Edith & -- & -- & -- & -- & -- & -- & -- \\
\hline $03 \mathrm{U}$ & Rio Blanco at Highway 84 & 16 & 6.7 & 17.4 & 9.8 & 7.8 & 9.4 & 10.8 \\
\hline $04 U$ & East Fork San Juan River above Sand Creek, near Pagosa Springs & -- & -- & -- & -- & -- & -- & -- \\
\hline $05 \mathrm{U}$ & Sand Creek at mouth above East Fork San Juan River & 12 & 7.6 & 11.9 & 9.5 & 8.1 & 9.5 & 11.3 \\
\hline $06 \mathrm{U}$ & West Fork San Juan River at West Fork Campground near Pagosa Springs & -- & -- & -- & -- & -- & -- & -- \\
\hline $07 \mathrm{U}$ & Wolf Creek at Wolf Creek Campground near Pagosa Springs & -- & -- & -- & -- & -- & -- & -- \\
\hline $08 \mathrm{U}$ & West Fork San Juan River near Pagosa Springs & -- & -- & -- & -- & -- & -- & -- \\
\hline 09U & San Juan River above Pagosa Springs & 41 & 6.5 & 13.7 & 10.2 & 8.4 & 10.6 & 11.6 \\
\hline $10 U$ & McCabe Creek above Pagosa Springs & 16 & 7.0 & 12.5 & 9.6 & 8.3 & 9.4 & 11.0 \\
\hline $11 \mathrm{U}$ & San Juan River at Pagosa Springs & -- & -- & -- & -- & -- & -- & -- \\
\hline $12 \mathrm{U}$ & San Juan River below Pagosa Springs & 10 & 8.8 & 14.5 & 11.4 & 9.7 & 11.4 & 13.9 \\
\hline $13 \mathrm{U}$ & San Juan River near Carracas & -- & -- & -- & -- & -- & -- & -- \\
\hline $14 U$ & San Juan River above Navajo Reservoir & 21 & 7.5 & 13.4 & 10.3 & 8.0 & 10.4 & 12.5 \\
\hline $15 \mathrm{U}$ & East Fork Piedra River below Piedra Falls & 12 & 6.6 & 12.0 & 9.6 & 6.8 & 10.1 & 11.6 \\
\hline $16 U$ & Piedra River at Highway 160 & 53 & 4.8 & 21.1 & 10.0 & 7.6 & 10.1 & 12.0 \\
\hline $17 \mathrm{U}$ & Stollsteimer Creek at Highway 151 & 17 & 6.0 & 23.3 & 10.0 & 7.3 & 9.4 & 11.4 \\
\hline $18 \mathrm{U}$ & Piedra River near Arboles & -- & -- & -- & -- & -- & -- & -- \\
\hline $19 U$ & Piedra River northeast of Arboles & 22 & 7.5 & 13.2 & 10.3 & 8.3 & 10.3 & 12.5 \\
\hline $20 U$ & Los Pinos River above Vallecito Reservoir near Bayfield & 17 & 6.9 & 10.9 & 8.5 & 7.5 & 8.3 & 9.5 \\
\hline $21 \mathrm{U}$ & Los Pinos River above Vallecito Reservoir & 50 & 5.5 & 12.8 & 9.7 & 7.9 & 9.9 & 11.8 \\
\hline $22 \mathrm{U}$ & Vallecito Creek near Bayfield & 94 & 7.8 & 11.6 & 9.7 & 8.1 & 10.2 & 10.8 \\
\hline $23 \mathrm{U}$ & Vallecito Creek near mouth & 54 & 6.0 & 13.0 & 9.8 & 8.4 & 10.0 & 11.0 \\
\hline $24 U$ & Los Pinos River below Vallecito Reservoir near Bayfield & 14 & 6.0 & 9.1 & 7.6 & 6.8 & 7.4 & 8.4 \\
\hline $25 \mathrm{U}$ & Wallace Gulch at 502 Road north of Bayfield & 16 & 5.9 & 9.7 & 7.8 & 6.0 & 8.1 & 9.0 \\
\hline $26 \mathrm{U}$ & Los Pinos River near Ignacio & -- & -- & -- & -- & -- & -- & -- \\
\hline $27 \mathrm{U}$ & Spring Creek at La Boca & -- & -- & -- & -- & -- & -- & -- \\
\hline $28 \mathrm{U}$ & Los Pinos River near La Boca & 10 & 7.6 & 15.3 & 10.6 & 8.2 & 10.5 & 12.3 \\
\hline
\end{tabular}


Table 2. Statistical summary for dissolved oxygen, $\mathrm{pH}$, and water-temperature data for sites with 10 or more samples in the Dolores, Upper San Juan, and Lower San Juan River Basins, southwestern Colorado, 1990-2005. - Continued

[Site ID, site identification number shown on figure 1; No., number of samples; Min, minimum value; Max, maximum value; --, not applicable; gray shaded columns indicate statistics that were used for comparison to State water-quality standards and values shown in red represent instances when State water-quality standards were not met; WWTP, wastewater treatment plant]

\begin{tabular}{|c|c|c|c|c|c|c|c|c|c|c|c|c|c|c|}
\hline \multirow[b]{2}{*}{ Site ID } & \multicolumn{7}{|c|}{ pH, standard units } & \multicolumn{7}{|c|}{ Water temperature, degrees Celsius } \\
\hline & No. & Min & Max & Mean & \multicolumn{3}{|c|}{ Percentiles } & No. & Min & Max & Mean & \multicolumn{3}{|c|}{ Percentiles } \\
\hline & & & & & & $\operatorname{an} \mathrm{J}$ & iver $\mathrm{B}$ & -Conti & & & & & & \\
\hline $33 \mathrm{~A}$ & 86 & 6.0 & 7.8 & 6.7 & 6.4 & 6.7 & 7.0 & 172 & 0.0 & 14.6 & 5.6 & 1.0 & 5.5 & 10.9 \\
\hline $34 \mathrm{~A}$ & 12 & 6.2 & 7.4 & 6.8 & 6.3 & 6.8 & 7.3 & 12 & 3.5 & 11.5 & 7.3 & 4.2 & 8.0 & 9.9 \\
\hline $35 \mathrm{~A}$ & 213 & 4.6 & 8.0 & 6.5 & 5.7 & 6.5 & 7.2 & 208 & 0.0 & 21.0 & 6.0 & 2.0 & 5.7 & 10.0 \\
\hline $36 \mathrm{~A}$ & 73 & 5.2 & 7.9 & 6.9 & 6.4 & 7.1 & 7.5 & 74 & -0.2 & 17.0 & 6.6 & 0.6 & 7.1 & 11.8 \\
\hline $39 \mathrm{~A}$ & 16 & 6.8 & 8.4 & 7.9 & 7.4 & 8.1 & 8.4 & 16 & 0.3 & 13.5 & 6.1 & 1.3 & 5.2 & 11.0 \\
\hline $40 \mathrm{~A}$ & 35 & 6.7 & 8.2 & 7.7 & 7.4 & 7.8 & 8.0 & 35 & 0.0 & 15.6 & 7.2 & 1.1 & 7.8 & 13.5 \\
\hline $41 \mathrm{~A}$ & 80 & 6.5 & 8.8 & 7.6 & 7.1 & 7.6 & 8.2 & 94 & -0.7 & 25.0 & 10.2 & 3.1 & 9.7 & 16.9 \\
\hline $42 \mathrm{~A}$ & 15 & 6.0 & 8.3 & 7.1 & 6.9 & 7.0 & 7.7 & -- & -- & -- & -- & -- & -- & -- \\
\hline $43 \mathrm{~A}$ & 12 & 7.5 & 8.6 & 8.1 & 7.8 & 8.2 & 8.4 & 13 & 0.0 & 16.2 & 6.9 & 0.7 & 7.6 & 12.8 \\
\hline $44 \mathrm{~A}$ & 16 & 6.4 & 8.1 & 7.2 & 6.8 & 7.1 & 7.5 & -- & -- & -- & -- & -- & -- & -- \\
\hline $50 \mathrm{~A}$ & 21 & 1.7 & 7.9 & 7.0 & 6.8 & 7.2 & 7.6 & -- & -- & -- & -- & -- & -- & -- \\
\hline $51 \mathrm{~A}$ & -- & -- & -- & -- & -- & -- & -- & 45 & 2.2 & 24.0 & 12.3 & 5.5 & 11.5 & 19.4 \\
\hline $52 \mathrm{~A}$ & 14 & 6.1 & 8.1 & 7.4 & 7.2 & 7.4 & 7.9 & -- & -- & -- & -- & -- & -- & -- \\
\hline $53 \mathrm{~A}$ & 24 & 6.8 & 8.8 & 7.7 & 7.1 & 7.7 & 8.3 & 24 & 0.1 & 18.6 & 7.1 & 0.6 & 6.4 & 14.3 \\
\hline $54 \mathrm{~A}$ & 14 & 7.6 & 8.7 & 8.3 & 7.9 & 8.4 & 8.6 & 15 & 0.1 & 26.3 & 12.2 & 1.9 & 10.2 & 23.6 \\
\hline $55 \mathrm{~A}$ & 13 & 7.2 & 8.5 & 7.9 & 7.3 & 8.1 & 8.4 & 15 & 0.6 & 20.0 & 10.1 & 1.5 & 11.0 & 18.6 \\
\hline $56 \mathrm{~A}$ & 13 & 6.3 & 8.2 & 7.6 & 7.2 & 7.7 & 8.0 & -- & -- & -- & -- & -- & -- & -- \\
\hline $57 \mathrm{~A}$ & 63 & 7.5 & 8.9 & 8.2 & 7.8 & 8.2 & 8.6 & 67 & 0.0 & 24.2 & 9.3 & 2.3 & 9.4 & 16.2 \\
\hline $01 \mathrm{U}$ & 16 & 6.5 & 8.2 & 7.5 & 6.8 & 7.7 & 8.2 & 16 & -0.2 & 21.6 & 7.2 & 0.0 & 2.8 & 16.6 \\
\hline $02 \mathrm{U}$ & -- & -- & -- & -- & -- & -- & -- & 43 & 0.0 & 21.0 & 9.7 & 1.5 & 10.5 & 15.5 \\
\hline $03 \mathrm{U}$ & 17 & 6.7 & 8.8 & 7.7 & 7.0 & 7.9 & 8.4 & 16 & -0.3 & 20.9 & 6.5 & 0.0 & 3.3 & 17.5 \\
\hline $04 \mathrm{U}$ & -- & -- & -- & -- & -- & -- & -- & 81 & 0.0 & 23.6 & 9.1 & 3.3 & 9.0 & 14.5 \\
\hline $05 \mathrm{U}$ & 12 & 7.3 & 8.3 & 7.8 & 7.3 & 7.9 & 8.3 & 12 & 2.0 & 20.4 & 10.8 & 2.4 & 12.2 & 18.4 \\
\hline $14 \mathrm{U}$ & 21 & 6.7 & 8.7 & 8.0 & 7.5 & 8.0 & 8.4 & 21 & 0.6 & 23.9 & 10.0 & 1.1 & 10.6 & 20.4 \\
\hline $15 \mathrm{U}$ & 12 & 7.2 & 8.7 & 7.8 & 7.3 & 7.8 & 8.0 & 12 & 0.3 & 25.0 & 9.1 & 1.6 & 8.5 & 17.0 \\
\hline $16 \mathrm{U}$ & 48 & 7.1 & 8.9 & 8.1 & 7.5 & 8.1 & 8.6 & 52 & 0.0 & 22.9 & 8.0 & 0.7 & 5.7 & 16.6 \\
\hline $17 \mathrm{U}$ & 18 & 6.4 & 8.7 & 8.0 & 7.3 & 8.2 & 8.5 & 18 & 0.0 & 28.5 & 11.3 & 0.2 & 10.5 & 23.0 \\
\hline $18 \mathrm{U}$ & -- & -- & -- & -- & -- & -- & -- & 118 & 0.0 & 27.8 & 10.4 & 3.2 & 9.3 & 19.5 \\
\hline $19 \mathrm{U}$ & 22 & 7.4 & 8.7 & 8.1 & 7.6 & 8.2 & 8.5 & 21 & 1.1 & 24.4 & 10.9 & 2.0 & 11.7 & 19.7 \\
\hline $20 \mathrm{U}$ & 17 & 6.5 & 8.3 & 7.7 & 7.2 & 7.7 & 8.1 & 17 & -0.2 & 21.0 & 11.8 & 6.1 & 12.0 & 18.5 \\
\hline $21 U$ & 49 & 7.0 & 8.7 & 7.8 & 7.3 & 7.8 & 8.3 & 52 & -0.3 & 20.1 & 6.7 & 0.0 & 6.2 & 13.5 \\
\hline $22 \mathrm{U}$ & 112 & 6.1 & 8.3 & 7.5 & 7.1 & 7.5 & 7.8 & 284 & 0.0 & 15.5 & 6.3 & 1.5 & 6.0 & 11.2 \\
\hline $23 \mathrm{U}$ & 51 & 6.7 & 8.7 & 7.6 & 7.3 & 7.5 & 8.0 & 54 & -0.2 & 18.1 & 6.0 & 1.1 & 5.4 & 10.8 \\
\hline $24 \mathrm{U}$ & 14 & 6.5 & 9.1 & 7.4 & 7.0 & 7.4 & 7.7 & 15 & 7.6 & 18.3 & 11.6 & 7.8 & 10.3 & 15.8 \\
\hline $25 \mathrm{U}$ & 15 & 7.0 & 8.6 & 7.7 & 7.4 & 7.6 & 8.1 & 16 & 2.7 & 20.1 & 10.5 & 5.6 & 9.5 & 15.4 \\
\hline $26 \mathrm{U}$ & -- & -- & -- & -- & -- & -- & -- & 35 & 0.0 & 26.1 & 11.7 & 3.5 & 10.9 & 22.0 \\
\hline $27 \mathrm{U}$ & -- & -- & -- & -- & -- & -- & -- & 101 & 0.0 & 28.0 & 11.5 & 0.5 & 13.0 & 20.0 \\
\hline $28 \mathrm{U}$ & 10 & 7.2 & 8.6 & 8.0 & 7.5 & 7.9 & 8.5 & 10 & 0.6 & 19.4 & 8.2 & 1.1 & 8.1 & 15.0 \\
\hline
\end{tabular}


Table 2. Statistical summary for dissolved oxygen, $\mathrm{pH}$, and water-temperature data for sites with 10 or more samples in the Dolores, Upper San Juan, and Lower San Juan River Basins, southwestern Colorado, 1990-2005._-Continued

[Site ID, site identification number shown on figure 1; No., number of samples; Min, minimum value; Max, maximum value; --, not applicable; gray shaded columns indicate statistics that were used for comparison to State water-quality standards and values shown in red represent instances when State water-quality standards were not met; WWTP, wastewater treatment plant]

\begin{tabular}{|c|c|c|c|c|c|c|c|c|}
\hline \multirow{3}{*}{$\begin{array}{c}\text { Site } \\
\text { ID }\end{array}$} & \multirow{3}{*}{ Site name } & \multicolumn{7}{|c|}{ Dissolved oxygen, milligrams per liter } \\
\hline & & \multirow{2}{*}{ No. } & \multirow{2}{*}{ Min } & \multirow{2}{*}{ Max } & \multirow{2}{*}{ Mean } & \multicolumn{3}{|c|}{ Percentiles } \\
\hline & & & & & & 15 & 50 & 85 \\
\hline \multicolumn{9}{|c|}{ Upper San Juan River Basin-Continued } \\
\hline $29 U$ & Los Pinos River at La Boca & -- & -- & -- & -- & -- & -- & -- \\
\hline $30 U$ & La Plata at Hesperus & 34 & 7.3 & 14.3 & 10.5 & 8.2 & 10.2 & 12.6 \\
\hline $31 \mathrm{U}$ & Spring Creek near Breen & 11 & 5.9 & 9.4 & 7.9 & 6.4 & 8.3 & 9.3 \\
\hline $32 U$ & East Fork Mancos River at 44 Road & 20 & 6.7 & 16.1 & 10.9 & 8.1 & 10.8 & 15.5 \\
\hline $33 \mathrm{U}$ & Mancos River at Mancos & 13 & 7.6 & 12.4 & 10.3 & 8.5 & 10.7 & 11.9 \\
\hline $34 U$ & Chicken Creek at Mancos & 16 & 7.1 & 14.0 & 9.6 & 7.8 & 9.1 & 11.8 \\
\hline $35 \mathrm{U}$ & Mancos River near Towaoc & -- & -- & -- & -- & -- & -- & -- \\
\hline $36 \mathrm{U}$ & Navajo Wash near Towaoc & -- & -- & -- & -- & -- & -- & -- \\
\hline \multicolumn{9}{|c|}{ Lower San Juan River Basin } \\
\hline $01 \mathrm{~L}$ & McElmo Creek above Cortez Sanitation District, Southwest WWTP & 15 & 7.0 & 12.9 & 9.8 & 7.6 & 9.5 & 12.4 \\
\hline 02L & Mud Creek at State Highway 32, near Cortez & -- & -- & -- & -- & -- & -- & -- \\
\hline 03L & McElmo Creek near Cortez & -- & -- & -- & -- & -- & -- & -- \\
\hline 04L & McElmo Creek above Trail Canyon near Cortez & -- & -- & -- & -- & -- & -- & -- \\
\hline $05 \mathrm{~L}$ & McElmo Creek above Trail Canyon at gage & 44 & 5.7 & 14.9 & 10.1 & 7.2 & 10.0 & 12.9 \\
\hline $06 \mathrm{~L}$ & McElmo Creek near Colorado-Utah State Line & -- & -- & -- & -- & -- & -- & -- \\
\hline
\end{tabular}

Table 2. Statistical summary for dissolved oxygen, $\mathrm{pH}$, and water-temperature data for sites with 10 or more samples in the Dolores, Upper San Juan, and Lower San Juan River Basins, southwestern Colorado, 1990-2005._Continued

[Site ID, site identification number shown on figure 1; No., number of samples; Min, minimum value; Max, maximum value; --, not applicable; gray shaded columns indicate statistics that were used for comparison to State water-quality standards and values shown in red represent instances when State water-quality standards were not met; WWTP, wastewater treatment plant]

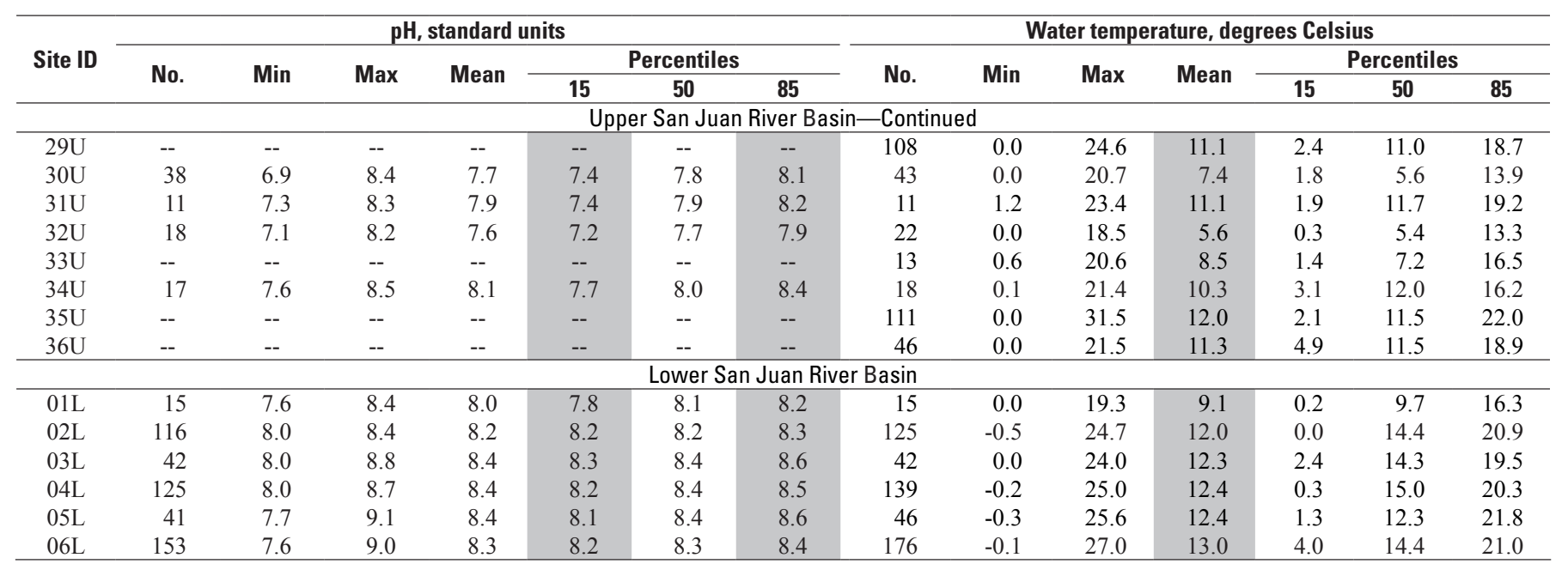


In the Upper SJRB, there were sufficient data to analyze for temporal trends in DO at only one site, Vallecito Creek near Bayfield (site 22U). This site was located west of Durango and upstream from Vallecito Reservoir. The typical DO concentration at this site was $10.0 \mathrm{mg} / \mathrm{L}$ (1993-2003), and there was no significant trend in DO concentrations (table 3).

Lower San Juan River Basin.- Only the McElmo Creek above Cortez Sanitation District, Southwest Wastewater Treatment Plant (WWTP) (site 01L) and McElmo Creek above Trail Canyon at gage (site 05L) sites had sufficient data to calculate summary statistics for DO (table 2 and fig. 1). The 15th percentile DO concentrations were $7.6 \mathrm{mg} / \mathrm{L}$ at McElmo Creek above Cortez Sanitation District, Southwest WWTP and 7.2 at McElmo Creek above Trail Canyon at gage (table 2). Sufficient data were not available to calculate trends.

\section{pH}

Values of $\mathrm{pH}$ in surface water generally were near neutral to slightly alkaline throughout most of the study area with the exception of the upper Animas River Basin near Silverton where acidic conditions existed at some sites because of hydrothermal alteration and(or) historical mining (Wright and others, 2007). Evaluation of existing water-quality conditions for $\mathrm{pH}$ was based on the range between the 15 th percentile and 85th percentile values (Colorado Department of Public Health and Environment, 2010b). The pH range used for the water-quality standard in most of the stream segments within the study area was 6.5 to 9.0 standard units (Colorado Department of Public Health and Environment, 2010a). However, several stream segments along Cement Creek and Mineral Creek in the upper Animas River Basin had designated waterquality standards for $\mathrm{pH}$ that ranged from 3.7 to 9.0 and 4.5 to 9.0, respectively (Colorado Department of Public Health and Environment, 2010b).

Dolores River Basin. - Twenty-eight sites had adequate data to calculate summary statistics for $\mathrm{pH}$ values. The 15th percentile values for $\mathrm{pH}$ ranged from 7.3 to 8.2 , and 85 th percentile values ranged from 7.7 to 8.9 (table 2 and fig. 5). Consequently, based on available data, $\mathrm{pH}$ values were within the physical and biological water-quality standard range for $\mathrm{pH}$ of 6.5 to 9.0 for sites in the Dolores River Basin.

Temporal trends in $\mathrm{pH}$ values were analyzed at three sites in the Dolores River Basin (table 3). Highly significant $(\mathrm{p}<0.01)$ small $(0.3$ percent) upward trends in $\mathrm{pH}$ occurred at the Dolores River at Bedrock (site 16D) and Dolores River near Bedrock (site 19D) sites (fig. 1). The typical $\mathrm{pH}$ for the trend analysis period (1993-2003) was 8.3 at the two sites. These small upward trends in $\mathrm{pH}$ values may result from a systematic shift in the time of day in which $\mathrm{pH}$ was measured at the sites or, perhaps, changes in geochemical characteristics resulting from operation of the Paradox Valley Unit.

Upper San Juan River Basin.-Adequate data were available to calculate summary statistics for $\mathrm{pH}$ values at 62 sites. The 15 th percentile values for $\mathrm{pH}$ ranged from 1.6 to 7.9 ; and 85 th percentile $\mathrm{pH}$ values ranged from 2.6 to 8.7 (table 2). The lowest $\mathrm{pH}$ values (15th percentile less than 4.5) occurred in the upper Animas River Basin in the Cement and Mineral Creek basins (fig. 5) which have been affected by historical mining activities. One site in the Mineral Creek basin and two sites in the Cement Creek basin had 15th percentile values for $\mathrm{pH}$ less than the surface-water-quality standard of 3.7 (table 2), the lowest designated State surface-water-quality standard value for $\mathrm{pH}$ in the study area (Colorado Department of Public Health and Environment, 2010a).

Seven sites in the Upper SJRB were analyzed for trends in $\mathrm{pH}$ values (table 3). The Animas River downstream from Silverton (site $35 \mathrm{~A})$, site had a highly significant $(\mathrm{p}<0.01)$ downward trend in $\mathrm{pH}$ values (table 3 ). The typical $\mathrm{pH}$ value at the site for the analysis period was 6.3. The reason for this trend is unknown. No other significant trends in $\mathrm{pH}$ values were measured at the other sites located in the Animas River near Silverton or at sites located in other areas of the Upper SJRB (table 3).

Lower San Juan River Basin.- Adequate data were available to calculate summary statistics for $\mathrm{pH}$ values at 6 sites. The 15 th percentile values for $\mathrm{pH}$ ranged from 7.8 to 8.3 ; and 85 th percentile values ranged from 8.2 to 8.6 (table 2). Consequently, $\mathrm{pH}$ values were within the State physical and biological water-quality standard range for $\mathrm{pH}$ of 6.5 to 9.0 at sites in the Lower SJRB (fig. 5).

Trends in $\mathrm{pH}$ values were analyzed at three sites in the Lower SJRB (table 3). Statistically significant upward trends in $\mathrm{pH}$ values occurred at Mud Creek at State Highway 32, near Cortez (site 02L), a tributary to McElmo Creek, and McElmo Creek above Trail Canyon near Cortez (site 04L). The upward trends in $\mathrm{pH}$ values at these sites could be the result of changes in stream-water quality resulting from urban and(or) agricultural activities or simply be an artifact of changes in sampling routines. During the latter part of the analysis period, the sites were consistently sampled later in the day when $\mathrm{pH}$ values may have been slightly higher. Additional data collection designed to address these issues would be needed to determine the cause of the upward trends in $\mathrm{pH}$ values.

\section{Water Temperature}

Mean water temperatures in the study area ranged from 5.3 to $14.1^{\circ} \mathrm{C}$ (table 2). Instantaneous water temperatures varied from less than 0 to $31.5^{\circ} \mathrm{C}$. Sites located in the headwaters of the Dolores River Basin and the Upper SJRB typically had mean water temperatures less than $10^{\circ} \mathrm{C}$. Lower elevation sites throughout the study area generally had mean water temperatures between 9 and $13{ }^{\circ} \mathrm{C}$.

As part of the 2007 rule making hearing, the Commission adopted $17^{\circ} \mathrm{C}$ as the maximum weekly average temperature (MWAT) interim chronic standard for small, high elevation streams (above 7,000 feet) that are likely to be habitat for brook trout and cutthroat trout, $18.2{ }^{\circ} \mathrm{C}$ (MWAT) as an interim chronic standard for waters designated by the Colorado 
Table 3. Summary of trend analysis results for dissolved-oxygen concentrations and pH and water-temperature values in the Dolores, Upper San Juan, and Lower San Juan River Basins, southwestern Colorado, 1993-2003.

[ID, site identification number shown on figure 1 ; milligrams per liter, $\mathrm{mg} / \mathrm{L} ;{ }^{\circ} \mathrm{C}$, degrees Celsius; $\mathrm{nt}$, not a significant trend; p-value, probability value; statistically significant trend at p-value less than or equal to 0.05 ; “--", available data did not meet the selection criteria; typical value is the median value for the trend analysis period; yr, year]

\begin{tabular}{|c|c|c|c|c|c|c|c|c|c|c|c|c|c|c|c|c|}
\hline \multirow[b]{3}{*}{$\begin{array}{c}\text { Site } \\
\text { ID }\end{array}$} & \multirow[b]{3}{*}{ Site name } & \multicolumn{5}{|c|}{ Dissolved oxygen, unfiltered } & \multicolumn{5}{|c|}{ pH } & \multicolumn{5}{|c|}{ Water temperature } \\
\hline & & \multirow[b]{2}{*}{$\begin{array}{c}\text { Typical } \\
\text { value } \\
\text { (mg/L) }\end{array}$} & \multirow[b]{2}{*}{ Trend } & \multirow[b]{2}{*}{$\begin{array}{c}\mathrm{p}- \\
\text { value }\end{array}$} & \multicolumn{2}{|c|}{ Trend slope } & \multirow[b]{2}{*}{$\begin{array}{l}\text { Typical } \\
\text { value } \\
\text { (standard } \\
\text { units) }\end{array}$} & \multirow[b]{2}{*}{ Trend } & \multirow[b]{2}{*}{$\begin{array}{c}\mathrm{p}- \\
\text { value }\end{array}$} & \multicolumn{2}{|c|}{ Trend slope } & \multirow[b]{2}{*}{$\begin{array}{c}\text { Typical } \\
\text { value } \\
\left({ }^{\circ} \mathrm{C}\right)\end{array}$} & \multirow[b]{2}{*}{ Trend } & \multirow[b]{2}{*}{$\begin{array}{c}\mathrm{p}- \\
\text { value }\end{array}$} & \multicolumn{2}{|c|}{ Trend slope } \\
\hline & & & & & $\begin{array}{l}\text { (per- } \\
\text { cent) }\end{array}$ & $\begin{array}{c}\text { (mg/L } \\
\text { per } \\
\text { yr) }\end{array}$ & & & & $\begin{array}{l}\text { (per- } \\
\text { cent) }\end{array}$ & $\begin{array}{l}\text { (stan- } \\
\text { dard } \\
\text { units } \\
\text { per yr) }\end{array}$ & & & & $\begin{array}{l}\text { (per- } \\
\text { cent) }\end{array}$ & $\left({ }^{\circ} \mathrm{C} / \mathrm{yr}\right)$ \\
\hline \multicolumn{17}{|c|}{ Dolores River Basin } \\
\hline $06 \mathrm{D}$ & Dolores River below Rico & -- & -- & -- & -- & -- & -- & -- & -- & -- & -- & $\mathrm{nt}$ & $\mathrm{nt}$ & $\mathrm{nt}$ & $\mathrm{nt}$ & $\mathrm{nt}$ \\
\hline $10 \mathrm{D}$ & Dolores River at Dolores & -- & -- & -- & -- & -- & -- & -- & -- & -- & -- & nt & $\mathrm{nt}$ & $\mathrm{nt}$ & $\mathrm{nt}$ & $\mathrm{nt}$ \\
\hline $16 \mathrm{D}$ & Dolores River at Bedrock & -- & -- & -- & -- & -- & 8.3 & up & 0.009 & 0.3 & 0.02 & $\mathrm{nt}$ & $\mathrm{nt}$ & $\mathrm{nt}$ & $\mathrm{nt}$ & $\mathrm{nt}$ \\
\hline 19D & Dolores River near Bedrock & -- & -- & -- & -- & -- & 8.3 & up & 0.008 & 0.3 & 0.03 & $\mathrm{nt}$ & $\mathrm{nt}$ & $\mathrm{nt}$ & $\mathrm{nt}$ & $\mathrm{nt}$ \\
\hline $25 \mathrm{D}$ & San Miguel River at Society Turn & -- & -- & -- & -- & -- & $\mathrm{nt}$ & $\mathrm{nt}$ & $\mathrm{nt}$ & $\mathrm{nt}$ & $\mathrm{nt}$ & nt & $\mathrm{nt}$ & $\mathrm{nt}$ & $\mathrm{nt}$ & $\mathrm{nt}$ \\
\hline $28 \mathrm{D}$ & San Miguel River near Placerville & -- & -- & -- & -- & -- & -- & -- & -- & -- & -- & $\mathrm{nt}$ & $\mathrm{nt}$ & $\mathrm{nt}$ & $\mathrm{nt}$ & $\mathrm{nt}$ \\
\hline $33 \mathrm{D}$ & San Miguel River at Uravan & -- & -- & -- & -- & -- & -- & -- & -- & -- & -- & $\mathrm{nt}$ & $\mathrm{nt}$ & $\mathrm{nt}$ & $\mathrm{nt}$ & $\mathrm{nt}$ \\
\hline \multicolumn{17}{|c|}{ Upper San Juan River Basin } \\
\hline $07 \mathrm{~A}$ & Animas River at Silverton (Agency ID A68) & -- & -- & -- & -- & -- & $\mathrm{nt}$ & $\mathrm{nt}$ & $\mathrm{nt}$ & $\mathrm{nt}$ & $\mathrm{nt}$ & -- & -- & -- & -- & -- \\
\hline $08 \mathrm{~A}$ & $\begin{array}{l}\text { Animas River at Silverton (Agency ID } \\
\text { 09358000) }\end{array}$ & -- & -- & -- & -- & -- & -- & -- & -- & -- & -- & $\mathrm{nt}$ & $\mathrm{nt}$ & $\mathrm{nt}$ & $\mathrm{nt}$ & $\mathrm{nt}$ \\
\hline $17 \mathrm{~A}$ & Cement Creek at Silverton & -- & -- & -- & -- & -- & -- & -- & -- & -- & -- & $\mathrm{nt}$ & $\mathrm{nt}$ & $\mathrm{nt}$ & $\mathrm{nt}$ & $\mathrm{nt}$ \\
\hline $31 \mathrm{~A}$ & Mineral Creek at Silverton & -- & -- & -- & -- & -- & -- & -- & -- & -- & -- & $\mathrm{nt}$ & $\mathrm{nt}$ & $\mathrm{nt}$ & $\mathrm{nt}$ & $\mathrm{nt}$ \\
\hline $32 \mathrm{~A}$ & USGS gaging station site - below Highway 550 & -- & -- & -- & -- & -- & nt & $\mathrm{nt}$ & $\mathrm{nt}$ & $\mathrm{nt}$ & $\mathrm{nt}$ & -- & -- & -- & -- & -- \\
\hline $33 \mathrm{~A}$ & Animas River below Silverton & -- & -- & -- & -- & -- & -- & -- & -- & -- & -- & $\mathrm{nt}$ & $\mathrm{nt}$ & $\mathrm{nt}$ & $\mathrm{nt}$ & $\mathrm{nt}$ \\
\hline $35 \mathrm{~A}$ & Animas River downstream from Silverton & -- & -- & -- & -- & -- & 6.3 & down & 0.005 & -2.4 & -0.15 & $\mathrm{nt}$ & $\mathrm{nt}$ & $\mathrm{nt}$ & $\mathrm{nt}$ & $\mathrm{nt}$ \\
\hline $36 \mathrm{~A}$ & Animas River near Silverton & -- & -- & -- & -- & -- & $\mathrm{nt}$ & $\mathrm{nt}$ & $\mathrm{nt}$ & $\mathrm{nt}$ & $\mathrm{nt}$ & $\mathrm{nt}$ & $\mathrm{nt}$ & $\mathrm{nt}$ & $\mathrm{nt}$ & $\mathrm{nt}$ \\
\hline $45 \mathrm{~A}$ & Animas River at Durango & -- & -- & -- & -- & -- & -- & -- & -- & -- & -- & $\mathrm{nt}$ & $\mathrm{nt}$ & $\mathrm{nt}$ & nt & $\mathrm{nt}$ \\
\hline $47 \mathrm{~A}$ & Lightner Creek at Mouth At Durango & -- & -- & -- & -- & -- & $\mathrm{nt}$ & $\mathrm{nt}$ & $\mathrm{nt}$ & $\mathrm{nt}$ & $\mathrm{nt}$ & -- & -- & -- & -- & -- \\
\hline $49 \mathrm{~A}$ & Animas River at Durango & -- & -- & -- & -- & -- & $\mathrm{nt}$ & $\mathrm{nt}$ & $\mathrm{nt}$ & $\mathrm{nt}$ & $\mathrm{nt}$ & -- & -- & -- & -- & -- \\
\hline $04 \mathrm{U}$ & $\begin{array}{l}\text { East Fork San Juan River at Sand Creek, Near } \\
\text { Pagosa Springs }\end{array}$ & -- & -- & -- & -- & -- & -- & -- & -- & -- & -- & $\mathrm{nt}$ & $\mathrm{nt}$ & $\mathrm{nt}$ & $\mathrm{nt}$ & $\mathrm{nt}$ \\
\hline
\end{tabular}


Table 3. Summary of trend analysis results for dissolved-oxygen concentrations and pH and water-temperature values in the Dolores, Upper San Juan, and Lower San Juan River Basins, southwestern Colorado, 1993-2003.—Continued

[ID, site identification number shown on figure 1 ; milligrams per liter, $\mathrm{mg} / \mathrm{L} ;{ }^{\circ} \mathrm{C}$, degrees Celsius; $\mathrm{nt}$, not a significant trend; p-value, probability value; statistically significant trend at p-value less than or equal to 0.05 ; “--", available data did not meet the selection criteria; typical value is the median value for the trend analysis period; yr, year]

\begin{tabular}{|c|c|c|c|c|c|c|c|c|c|c|c|c|c|c|c|c|}
\hline \multirow[b]{3}{*}{$\begin{array}{c}\text { Site } \\
\text { ID }\end{array}$} & \multirow[b]{3}{*}{ Site name } & \multicolumn{5}{|c|}{ Dissolved oxygen, unfiltered } & \multicolumn{5}{|c|}{ pH } & \multicolumn{5}{|c|}{ Water temperature } \\
\hline & & \multirow[b]{2}{*}{$\begin{array}{c}\text { Typical } \\
\text { value } \\
\text { (mg/L) }\end{array}$} & \multirow[b]{2}{*}{ Trend } & \multirow[b]{2}{*}{$\begin{array}{c}\mathrm{p}- \\
\text { value }\end{array}$} & \multicolumn{2}{|c|}{ Trend slope } & \multirow[b]{2}{*}{$\begin{array}{l}\text { Typical } \\
\text { value } \\
\text { (standard } \\
\text { units) }\end{array}$} & \multirow[b]{2}{*}{ Trend } & \multirow[b]{2}{*}{$\begin{array}{c}\text { p- } \\
\text { value }\end{array}$} & \multicolumn{2}{|c|}{ Trend slope } & \multirow[b]{2}{*}{$\begin{array}{c}\text { Typical } \\
\text { value } \\
\left({ }^{\circ} \mathrm{C}\right)\end{array}$} & \multirow[b]{2}{*}{ Trend } & \multirow[b]{2}{*}{$\begin{array}{c}\text { p- } \\
\text { value }\end{array}$} & \multicolumn{2}{|c|}{ Trend slope } \\
\hline & & & & & $\begin{array}{l}\text { (per- } \\
\text { cent) }\end{array}$ & $\begin{array}{c}\text { (mg/L } \\
\text { per } \\
\text { yr) }\end{array}$ & & & & $\begin{array}{l}\text { (per- } \\
\text { cent) }\end{array}$ & $\begin{array}{c}\text { (stan- } \\
\text { dard } \\
\text { units } \\
\text { per yr) }\end{array}$ & & & & $\begin{array}{l}\text { (per- } \\
\text { cent) }\end{array}$ & $\left({ }^{\circ} \mathrm{C} / \mathrm{yr}\right)$ \\
\hline \multicolumn{17}{|c|}{ Upper San Juan River Basin-Continued } \\
\hline $11 \mathrm{U}$ & San Juan River at Pagosa Springs & -- & -- & -- & -- & -- & -- & -- & -- & -- & -- & 5.7 & up & 0.049 & 3.9 & 0.2 \\
\hline $13 \mathrm{U}$ & San Juan River near Carracas & -- & -- & -- & -- & -- & -- & -- & -- & -- & -- & $\mathrm{nt}$ & $\mathrm{nt}$ & $\mathrm{nt}$ & nt & nt \\
\hline $18 \mathrm{U}$ & Piedra River near Arboles & -- & -- & -- & -- & -- & -- & -- & -- & -- & -- & $\mathrm{nt}$ & $\mathrm{nt}$ & $\mathrm{nt}$ & $\mathrm{nt}$ & $\mathrm{nt}$ \\
\hline $22 \mathrm{U}$ & Vallecito Creek near Bayfield & $\mathrm{nt}$ & $\mathrm{nt}$ & $\mathrm{nt}$ & $\mathrm{nt}$ & $\mathrm{nt}$ & $\mathrm{nt}$ & $\mathrm{nt}$ & $\mathrm{nt}$ & $\mathrm{nt}$ & $\mathrm{nt}$ & $\mathrm{nt}$ & $\mathrm{nt}$ & $\mathrm{nt}$ & $\mathrm{nt}$ & nt \\
\hline $27 \mathrm{U}$ & Spring Creek at La Boca & -- & -- & -- & -- & -- & -- & -- & -- & -- & -- & $\mathrm{nt}$ & $\mathrm{nt}$ & $\mathrm{nt}$ & $\mathrm{nt}$ & $\mathrm{nt}$ \\
\hline $29 \mathrm{U}$ & Los Pinos River at La Boca & -- & -- & -- & -- & -- & -- & -- & -- & -- & -- & 10.9 & up & 0.041 & 3.5 & 0.4 \\
\hline $35 \mathrm{U}$ & Mancos River near Towaoc & -- & -- & -- & -- & -- & -- & -- & -- & -- & -- & $\mathrm{nt}$ & $\mathrm{nt}$ & $\mathrm{nt}$ & $\mathrm{nt}$ & $\mathrm{nt}$ \\
\hline \multicolumn{17}{|c|}{ Lower San Juan River Basin } \\
\hline $02 \mathrm{~L}$ & Mud Creek at State Highway 32, near Cortez & -- & -- & -- & -- & -- & 8.3 & up & 0.020 & 0.2 & 0.02 & nt & nt & $\mathrm{nt}$ & $\mathrm{nt}$ & $\mathrm{nt}$ \\
\hline $04 \mathrm{~L}$ & $\begin{array}{l}\text { McElmo Creek above Trail Canyon near } \\
\text { Cortez }\end{array}$ & -- & -- & -- & -- & -- & 8.4 & up & 0.009 & 0.3 & 0.03 & $\mathrm{nt}$ & $\mathrm{nt}$ & $\mathrm{nt}$ & $\mathrm{nt}$ & $\mathrm{nt}$ \\
\hline $06 \mathrm{~L}$ & McElmo Creek near Colorado-Utah State Line & -- & -- & -- & -- & -- & $\mathrm{nt}$ & $\mathrm{nt}$ & $\mathrm{nt}$ & nt & $\mathrm{nt}$ & $\mathrm{nt}$ & $\mathrm{nt}$ & $\mathrm{nt}$ & $\mathrm{nt}$ & $\mathrm{nt}$ \\
\hline
\end{tabular}




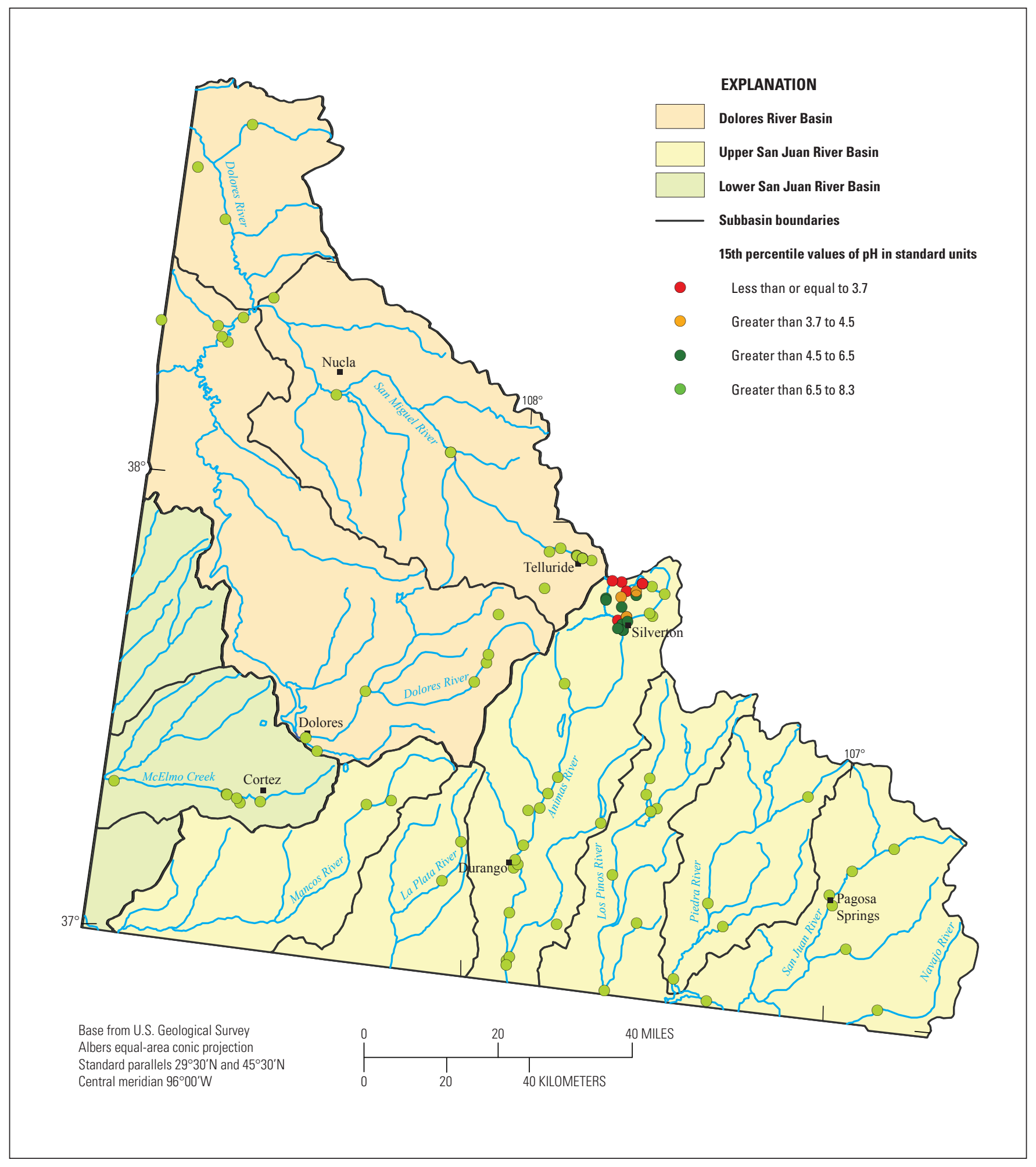

Figure 5. Map showing spatial distribution of 15th percentile pH values in the Dolores, Upper San Juan, and Lower San Juan River Basins, southwestern Colorado, 1990-2005. 
Wildlife Commission as "Gold Medal Fisheries," $20{ }^{\circ} \mathrm{C}$ (MWAT) as an interim chronic standard for the remainder of the cold-water segments, and $30{ }^{\circ} \mathrm{C}$ (MWAT) as an interim chronic standard for warm-water segments (Colorado Department of Public Health and Environment, 2010a). Mean water temperatures were calculated for each site using available data. These mean values, along with the other summary statistic values shown in table 2, likely do not represent the actual range in water temperature or the MWAT at each site, because these samples were collected sporadically over long periods of time.

Dolores River Basin.-Water temperature data were analyzed at 36 sites in the Dolores River Basin. Mean water temperatures ranged from 5.7 to $14.1^{\circ} \mathrm{C}$ (table 2). As expected, the lowest mean water temperatures occurred at sites in the mountainous upper part of the Dolores River Basin where air temperatures were cooler. The highest mean water temperatures occurred at sites in the lower part of the basin. Temporal trends in water temperature were evaluated at seven sites (table 3). No significant trends in water temperature occurred.

Upper San Juan River Basin.-Water temperature data were analyzed at 74 sites in the Upper SJRB. Mean water temperatures ranged from 5.3 to $13.6{ }^{\circ} \mathrm{C}$ (table 2). Sites located in the upper Animas River Basin in the vicinity of Silverton and in the San Juan River Basin upstream from Pagosa Springs typically had mean water temperatures less than $10{ }^{\circ} \mathrm{C}$. Lower elevation sites, near the ColoradoNew Mexico State line generally had mean water temperatures between 9 and $12{ }^{\circ} \mathrm{C}$.

Fifteen sites were analyzed for trends in water temperature in the Upper SJRB (table 3). Two of the 15 sites had statistically significant upward trends in water temperatures. An increase of 3.9 percent occurred at the San Juan River at Pagosa Springs (site 11U) site where the typical water temperature for the period of analysis was $5.7^{\circ} \mathrm{C}$. A 3.5 percent increase in water temperature occurred at the Los Pinos River at La Boca (site 29U) site where the typical water temperature for the period of analysis (19932003) was $10.9^{\circ} \mathrm{C}$. Instantaneous streamflow values measured when water-quality samples were collected were generally lower during the last half of the analysis period than during the first half of the analysis period. These upward trends in water temperature may result from changes in groundwater and surface water interactions and(or) changes in stream velocities and depths because of drought conditions during the latter part of the analysis period.

Lower San Juan River Basin. Water temperature data were analyzed at 6 sites in the Lower SJRB. All sites were located in the McElmo Creek basin. Five of the six sites had mean water temperatures that ranged from 12 to $13.0^{\circ} \mathrm{C}$ (table 2). The remaining site, McElmo Creek above Cortez Sanitation District, Southwest WWTP, had a mean water temperature of $9.1^{\circ} \mathrm{C}$. Water temperature data were analyzed for trends at Mud Creek at State Highway 32, near Cortez (site 02L), McElmo Creek above Trail Canyon near Cortez (site 04L), and McElmo Creek near Colorado-Utah State line (site 06L) (table 3 and fig. 1). No significant trends in water temperature data occurred at these sites.

\section{Dissolved Solids}

As with most water-quality characteristic data in the study area, more sites were analyzed for dissolved solids (DS) in the Upper SJRB than the Dolores River Basin and the Lower SJRB (table 4). No State surface-water-quality standards were listed for DS concentrations in southwestern Colorado (Colorado Department of Public Health and Environment, 2010a). The national secondary standard for DS in drinking water was $500 \mathrm{mg} / \mathrm{L}$ (U.S. Environmental Protection Agency, 2010b). In the study area, median DS concentrations ranged from 8 to $42,600 \mathrm{mg} / \mathrm{L}$. Median DS concentrations equal to or greater than $500 \mathrm{mg} / \mathrm{L}$ were measured at some sites in the Dolores River Basin, at one site in the Upper SJRB, and at all sites in the Lower SJRB. The highest DS concentrations typically occurred in samples collected from December through March when streamflows were lowest and groundwater inflow was the dominant source of flow. The lowest DS concentrations typically occurred in samples collected from May through July when streamflows were highest and snowmelt was the dominant source of the flow (fig. 6). Seasonal differences in DS concentrations were more apparent in samples from the Upper SJRB and the Lower SJRB than the Dolores River Basin (fig. 6). Generally, $\mathrm{SC}$ values are highly correlated with DS concentrations. Throughout the study area, more sites had adequate SC data than DS data; consequently, both SC values and DS concentrations were analyzed for temporal trends. Trend analyses for $\mathrm{SC}$ values and DS concentrations are described in this section of the report and shown in table 5.

Dolores River Basin.-Dissolved-solids data were analyzed at 22 sites. Median DS concentrations ranged from 120 to $42,600 \mathrm{mg} / \mathrm{L}$ (table 4 ). Fourteen of the 22 sites analyzed in the Dolores River Basin had median DS concentrations less than $500 \mathrm{mg} / \mathrm{L}$ (table 4 and fig. 7). The highest median DS concentration $(42,600 \mathrm{mg} / \mathrm{L})$ occurred at Salt Creek at Highway 141 (site 35D) downstream from the confluence of the Dolores and San Miguel Rivers (fig. 7). In the Dolores River between the Dolores River at Bedrock (16D) and Dolores River near Bedrock (19D) sites, median DS concentrations in the river almost tripled going from 426 to $1,275 \mathrm{mg} / \mathrm{L}$ (table 4 and fig. 7). The increase in DS in the Dolores River between these two sites is mostly because of increases in dissolved sodium and chloride concentrations resulting from inflow of saline groundwater to the river as it flows through the Paradox Valley (Watts, 2000).

In the Dolores River Basin, trends in DS concentrations were analyzed at only two sites; whereas, trends in $\mathrm{SC}$ values were analyzed at six sites (table 5). Significant downward trends in DS concentrations and SC values occurred at Dolores River near Bedrock (site 19D). 
Table 4. Statistical summary for dissolved solids and specific conductance data for sites with 10 or more samples in the Dolores, Upper San Juan, and Lower San Juan River Basins, southwestern Colorado, 1990-2005.

[Site ID, number identifying location on figure 1; mg/L, milligrams per liter; $\mu \mathrm{S} / \mathrm{cm}$, microsiemens per centimeter at 25 degrees Celsius; No., number of samples; Min, minimum value; Max, maximum value; Med, median value; --, no value; Agency ID was added in parenthesis to the site name when sites had identical names; WWTP, wastewater treatment plant; gray shaded column indicates statistic that was used for comparison to National water-quality standards and values shown in red represent instances when water-quality standard was not met]

\begin{tabular}{|c|c|c|c|c|c|c|c|c|c|c|c|c|}
\hline \multirow{2}{*}{$\begin{array}{c}\text { Site } \\
\text { ID }\end{array}$} & \multirow{2}{*}{ Site name } & \multirow{2}{*}{ Subbasin name } & \multicolumn{5}{|c|}{ Dissolved solids, in mg/L } & \multicolumn{5}{|c|}{ Specific conductance, in $\mu \mathrm{S} / \mathrm{cm}$} \\
\hline & & & Number & Minimum & Maximum & Mean & Median & Number & Minimum & Maximum & Mean & Median \\
\hline \multicolumn{13}{|c|}{ Dolores River Basin } \\
\hline $02 \mathrm{D}$ & Horse Creek at Highway 145 & Upper Dolores & -- & -- & -- & -- & -- & 10 & 113 & 274 & 208 & 222 \\
\hline 03D & Dolores River above Horse Creek & Upper Dolores & 13 & 129 & 85 & 130 & 170 & -- & -- & -- & -- & -- \\
\hline 04D & Silver Creek at Highway 145 & Upper Dolores & 42 & 82 & 520 & 287 & 305 & 12 & 132 & 594 & 378 & 364 \\
\hline $05 \mathrm{D}$ & Dolores River below Rico (Agency ID 09165000) & Upper Dolores & -- & -- & -- & -- & -- & 115 & 106 & 696 & 326 & 322 \\
\hline $06 \mathrm{D}$ & Dolores River below Rico (Agency ID 10716) & Upper Dolores & 43 & 78 & 410 & 247 & 260 & 20 & 128 & 589 & 371 & 358 \\
\hline 07D & West Dolores River near Stoner at Highway 145 & Upper Dolores & 14 & 237 & 130 & 225 & 350 & -- & -- & -- & -- & -- \\
\hline 08D & Lost Canyon Creek near Dolores & Upper Dolores & -- & -- & -- & -- & -- & 88 & 48 & 1,280 & 303 & 187 \\
\hline 09D & Lost Canyon Creek near Dolores & Upper Dolores & 11 & 84 & 160 & 119 & 120 & 13 & 63 & 283 & 177 & 186 \\
\hline $10 \mathrm{D}$ & Dolores River at Dolores & Upper Dolores & -- & -- & -- & -- & -- & 123 & 123 & 1,230 & 309 & 304 \\
\hline $12 \mathrm{D}$ & Dolores River near town of Dolores & Upper Dolores & 14 & 184 & 91 & 170 & 280 & -- & -- & -- & -- & -- \\
\hline $13 \mathrm{D}$ & Dolores River at Dolores above Mcphee Reservoir & Upper Dolores & 21 & 110 & 310 & 216 & 240 & 25 & 139 & 503 & 329 & 315 \\
\hline $14 \mathrm{D}$ & Dolores River near Slick Rock & Upper Dolores & -- & -- & -- & -- & -- & 38 & 264 & 960 & 491 & 427 \\
\hline $15 \mathrm{D}$ & $\begin{array}{l}\text { Dolores River above confluence with San Miguel } \\
\text { River }\end{array}$ & Upper Dolores & 38 & 220 & 7,010 & 2,524 & 2,395 & 25 & 366 & 11,800 & 4,519 & 4,040 \\
\hline $16 \mathrm{D}$ & Dolores River at Bedrock & Upper Dolores & 158 & 158 & 2,260 & 478 & 426 & 184 & 283 & 2,490 & 788 & 687 \\
\hline $17 \mathrm{D}$ & Lasal Creek at Utah-Colorado State Line & Upper Dolores & 23 & 142 & 368 & 252 & 248 & 36 & 203 & 544 & 412 & 417 \\
\hline $18 \mathrm{D}$ & West Paradox Creek above Bedrock & Upper Dolores & 102 & 149 & 1,520 & 737 & 760 & 104 & 257 & 2,140 & 1,069 & 1,110 \\
\hline 19D & Dolores River near Bedrock & Upper Dolores & 156 & 174 & 12,200 & 1,890 & 1,275 & 177 & 304 & 20,767 & 3,130 & 2,007 \\
\hline $21 \mathrm{D}$ & (2), Bear Creek & San Miguel & -- & -- & -- & -- & -- & 11 & 0.09 & 0.18 & 0.13 & 0.12 \\
\hline $22 \mathrm{D}$ & Upstream, SMIG above Bear & San Miguel & -- & -- & -- & -- & -- & 12 & 0.14 & 244 & 21 & 0.25 \\
\hline $23 \mathrm{D}$ & (7), Coronet & San Miguel & -- & -- & -- & -- & -- & 11 & 0.12 & 0.25 & 0.20 & 0.21 \\
\hline $24 \mathrm{D}$ & Downstream, SMMAHONEY & San Miguel & -- & -- & -- & -- & -- & 12 & 0.14 & 253 & 21 & 0.24 \\
\hline $25 \mathrm{D}$ & San Miguel River at Society Turn & San Miguel & 73 & 52 & 1,600 & 198 & 200 & 36 & 136 & 376 & 287 & 312 \\
\hline $26 \mathrm{D}$ & South Fork San Miguel River near mouth & San Miguel & 21 & 170 & 650 & 332 & 340 & 12 & 293 & 523 & 442 & 471 \\
\hline $27 \mathrm{D}$ & Howard Fork San Miguel River at Ophir & San Miguel & 16 & 484 & 270 & 515 & 610 & -- & -- & -- & -- & -- \\
\hline $28 \mathrm{D}$ & San Miguel River near Placerville & San Miguel & -- & -- & -- & -- & -- & 139 & 178 & 566 & 343 & 367 \\
\hline 29D & San Miguel River near Norwood & San Miguel & 31 & 120 & 300 & 238 & 260 & 19 & 230 & 489 & 370 & 380 \\
\hline $30 \mathrm{D}$ & $\begin{array}{l}\text { McKenzie Creek at mouth above confluence with } \\
\text { San Miguel River }\end{array}$ & San Miguel & 16 & 130 & 370 & 322 & 345 & 16 & 174 & 605 & 530 & 578 \\
\hline $31 \mathrm{D}$ & San Miguel River at Brooks Bridge near Nucla & San Miguel & -- & -- & -- & -- & -- & 89 & 178 & 665 & 361 & 353 \\
\hline
\end{tabular}


Table 4. Statistical summary for dissolved solids and specific conductance data for sites with 10 or more samples in the Dolores, Upper San Juan, and Lower San Juan River Basins, southwestern Colorado, 1990-2005.-Continued

[Site ID, number identifying location on figure 1; mg/L, milligrams per liter; $\mu \mathrm{S} / \mathrm{cm}$, microsiemens per centimeter at 25 degrees Celsius; No., number of samples; Min, minimum value; Max, maximum value; Med, median value; --, no value; Agency ID was added in parenthesis to the site name when sites had identical names; WWTP, wastewater treatment plant; gray shaded column indicates statistic that was used for comparison to National water-quality standards and values shown in red represent instances when water-quality standard was not met]

\begin{tabular}{|c|c|c|c|c|c|c|c|c|c|c|c|c|}
\hline \multirow{2}{*}{$\begin{array}{l}\text { Site } \\
\text { ID }\end{array}$} & \multirow{2}{*}{ Site name } & \multirow{2}{*}{ Subbasin name } & \multicolumn{5}{|c|}{ Dissolved solids, in mg/L } & \multicolumn{5}{|c|}{ Specific conductance, in $\mu \mathrm{S} / \mathrm{cm}$} \\
\hline & & & Number & Minimum & Maximum & Mean & Median & Number & Minimum & Maximum & Mean & Median \\
\hline \multicolumn{13}{|c|}{ Dolores River Basin-Continued } \\
\hline $32 \mathrm{D}$ & Naturita Creek at Naturita & San Miguel & 16 & 1,490 & 220 & 1,570 & 2,300 & -- & -- & -- & -- & -- \\
\hline $33 \mathrm{D}$ & San Miguel River at Uravan & San Miguel & -- & -- & -- & -- & -- & 123 & 217 & 1,922 & 738 & 721 \\
\hline $34 \mathrm{D}$ & San Miguel River at confluence with Dolores River & San Miguel & 60 & 180 & 1,610 & 637 & 610 & 49 & 292 & 1,951 & 804 & 780 \\
\hline $35 \mathrm{D}$ & Salt Creek at Highway 141 & Lower Dolores & 12 & 4,100 & 59,200 & 43,040 & 42,600 & 12 & 3,727 & 83,500 & 36,561 & 29,846 \\
\hline $36 \mathrm{D}$ & West Creek in Unaweep Canyon & Lower Dolores & 13 & 214 & 170 & 220 & 240 & & & & & \\
\hline 37D & Dolores River at Gateway & Lower Dolores & 17 & 570 & 3,090 & 1,241 & 1,040 & 19 & 346 & 5,200 & 1,838 & 1,570 \\
\hline \multicolumn{13}{|c|}{ Upper San Juan River Basin } \\
\hline $02 \mathrm{~A}$ & Animas River at Eureka & Animas & -- & -- & -- & -- & -- & 23 & 71 & 282 & 133 & 122 \\
\hline $03 \mathrm{~A}$ & Eureka below Ben Franklin & Animas & -- & -- & -- & -- & -- & 21 & 127 & 333 & 210 & 213 \\
\hline $04 \mathrm{~A}$ & Animas River at Howardsville & Animas & -- & -- & -- & -- & -- & 16 & 94 & 305 & 191 & 177 \\
\hline $05 \mathrm{~A}$ & Animas River downstream from Arrastra Gulch & Animas & -- & -- & -- & -- & -- & 10 & 106 & 270 & 173 & 160 \\
\hline $07 \mathrm{~A}$ & Animas River at Silverton (Agency ID A68) & Animas & -- & -- & -- & -- & -- & 139 & 76 & 433 & 245 & 250 \\
\hline $08 \mathrm{~A}$ & Animas River at Silverton (Agency ID 09358000) & Animas & -- & -- & -- & -- & -- & 112 & 108 & 430 & 257 & 269 \\
\hline $17 \mathrm{~A}$ & Cement Creek at Silverton (Agency ID 09358550) & Animas & -- & -- & -- & -- & -- & 107 & 166 & 1,274 & 736 & 850 \\
\hline $20 \mathrm{~A}$ & Mineral Creek near headwaters & Animas & -- & -- & -- & -- & -- & 14 & 500 & 3,800 & 2,153 & 2,375 \\
\hline $21 \mathrm{~A}$ & $\begin{array}{l}\text { Highway } 550 \text { drainage ditch above M01 conflu- } \\
\text { ence-east side of Highway } 550\end{array}$ & Animas & -- & -- & -- & -- & -- & 14 & 290 & 2,900 & 1,511 & 1,695 \\
\hline $22 \mathrm{~A}$ & Mineral Creek at Chattanooga & Animas & -- & -- & -- & -- & -- & 15 & 62 & 593 & 186 & 115 \\
\hline $25 \mathrm{~A}$ & Mineral Creek at Burro Bridge (Agency ID M13A) & Animas & -- & -- & -- & -- & -- & 11 & 91 & 691 & 269 & 187 \\
\hline $30 \mathrm{~A}$ & $\begin{array}{l}\text { Mineral Creek above confluence with South Fork } \\
\text { Mineral Creek }\end{array}$ & Animas & -- & -- & -- & -- & -- & 11 & 165 & 942 & 430 & 293 \\
\hline $31 \mathrm{~A}$ & Mineral Creek at Silverton (Agency ID 09359010) & Animas & -- & -- & -- & -- & -- & 106 & 103 & 730 & 350 & 373 \\
\hline $32 \mathrm{~A}$ & Mineral Creek at Silverton (Agency ID M34) & Animas & -- & -- & -- & -- & -- & 144 & 87 & 649 & 313 & 305 \\
\hline $33 \mathrm{~A}$ & Animas River below Silverton & Animas & 44 & 78 & 425 & 231 & 220 & 172 & 84 & 662 & 369 & 370 \\
\hline $35 \mathrm{~A}$ & Animas River downstream from Silverton & Animas & -- & -- & -- & -- & -- & 177 & 110 & 642 & 335 & 340 \\
\hline $36 \mathrm{~A}$ & Animas River near Silverton & Animas & 72 & 61 & 530 & 277 & 280 & 51 & 130 & 699 & 376 & 370 \\
\hline $37 \mathrm{~A}$ & Big Eldorado inflow & Animas & 24 & 3.6 & 47.2 & 17 & 12 & 13 & 2 & 59 & 28 & 28 \\
\hline $38 \mathrm{~A}$ & Little Eldorado inflow & Animas & 14 & 4.7 & 9.7 & 8 & 8 & 13 & 10 & 18 & 13 & 13 \\
\hline $39 \mathrm{~A}$ & Cascade Creek at Highway 550 & Animas & 14 & 110 & 230 & 198 & 210 & 14 & 135 & 397 & 324 & 351 \\
\hline $40 \mathrm{~A}$ & Animas River above Durango & Animas & 35 & 192 & 58 & 190 & 370 & -- & -- & -- & -- & -- \\
\hline
\end{tabular}


Table 4. Statistical summary for dissolved solids and specific conductance data for sites with 10 or more samples in the Dolores, Upper San Juan, and Lower San Juan River Basins, southwestern Colorado, 1990-2005.-Continued

[Site ID, number identifying location on figure 1; mg/L, milligrams per liter; $\mu \mathrm{S} / \mathrm{cm}$, microsiemens per centimeter at 25 degrees Celsius; No., number of samples; Min, minimum value; Max, maximum value; Med, median value; --, no value; Agency ID was added in parenthesis to the site name when sites had identical names; WWTP, wastewater treatment plant; gray shaded column indicates statistic that was used for comparison to National water-quality standards and values shown in red represent instances when water-quality standard was not met]

\begin{tabular}{|c|c|c|c|c|c|c|c|c|c|c|c|c|}
\hline \multirow{2}{*}{$\begin{array}{l}\text { Site } \\
\text { ID }\end{array}$} & \multirow{2}{*}{ Site name } & \multirow{2}{*}{ Subbasin name } & \multicolumn{5}{|c|}{ Dissolved solids, in mg/L } & \multicolumn{5}{|c|}{ Specific conductance, in $\mu \mathrm{S} / \mathrm{cm}$} \\
\hline & & & Number & Minimum & Maximum & Mean & Median & Number & Minimum & Maximum & Mean & Median \\
\hline \multicolumn{13}{|c|}{ Upper San Juan River Basin_-Continued } \\
\hline $42 \mathrm{~A}$ & Trimble Lane Bridge & Animas & -- & -- & -- & -- & -- & 15 & 155 & 651 & 345 & 347 \\
\hline $43 \mathrm{~A}$ & Falls Creek at 0.65 Road & Animas & 11 & 150 & 270 & 215 & 220 & 12 & 175 & 404 & 311 & 322 \\
\hline $44 \mathrm{~A}$ & Animas at 32nd Street Bridge & Animas & -- & -- & -- & -- & -- & 16 & 138 & 669 & 374 & 397 \\
\hline $45 \mathrm{~A}$ & Animas River at Durango (Agency ID 09361500) & Animas & -- & -- & -- & -- & -- & 117 & 123 & 898 & 413 & 420 \\
\hline $46 \mathrm{~A}$ & Animas River at Durango (Agency ID 9420) & Animas & 27 & 100 & 560 & 328 & 360 & 29 & 160 & 910 & 506 & 554 \\
\hline $51 \mathrm{~A}$ & Wilson Gulch near Durango & Animas & -- & -- & -- & -- & -- & 45 & 310 & 949 & 632 & 660 \\
\hline $52 \mathrm{~A}$ & Weaselskin & Animas & -- & -- & -- & -- & -- & 14 & 159 & 726 & 416 & 412 \\
\hline $53 \mathrm{~A}$ & Florida River below Lemon Reservoir & Animas & 22 & 58 & 190 & 99 & 93 & 13 & 120 & 280 & 183 & 160 \\
\hline $54 \mathrm{~A}$ & Salt Creek at 309A Road & Animas & 14 & 110 & 660 & 278 & 160 & 12 & 194 & 1,086 & 490 & 366 \\
\hline $55 \mathrm{~A}$ & Florida River at confluence with Las Animas River & Animas & 15 & 245 & 110 & 240 & 340 & -- & -- & -- & -- & -- \\
\hline $56 \mathrm{~A}$ & Animas River at Bondad & Animas & -- & -- & -- & -- & -- & 13 & 152 & 760 & 417 & 429 \\
\hline $57 \mathrm{~A}$ & Animas River near Bondad & Animas & 66 & 75 & 470 & 282 & 315 & 24 & 174 & 740 & 432 & 417 \\
\hline $01 \mathrm{U}$ & Little Navajo River at Highway 84 & Upper San Juan & 15 & 130 & 400 & 231 & 240 & 15 & 141 & 587 & 379 & 389 \\
\hline $02 \mathrm{U}$ & Navajo River at Edith & Upper San Juan & -- & -- & -- & -- & -- & 43 & 92 & 421 & 226 & 234 \\
\hline $03 \mathrm{U}$ & Rio Blanco at Highway 84 & Upper San Juan & 15 & 110 & 400 & 263 & 280 & 17 & 93 & 797 & 395 & 448 \\
\hline $04 \mathrm{U}$ & $\begin{array}{l}\text { East Fork San Juan River above Sand Creek, near } \\
\text { Pagosa Springs }\end{array}$ & Upper San Juan & -- & -- & -- & -- & -- & 81 & 72 & 241 & 123 & 120 \\
\hline $05 \mathrm{U}$ & $\begin{array}{l}\text { Sand Creek at mouth above East Fork San Juan } \\
\text { River }\end{array}$ & Upper San Juan & 11 & 38 & 77 & 61 & 62 & 12 & 51 & 101 & 78 & 78 \\
\hline $06 \mathrm{U}$ & $\begin{array}{l}\text { West Fork San Juan River at West Fork Camp- } \\
\text { ground near Pagosa Springs }\end{array}$ & Upper San Juan & -- & -- & -- & -- & -- & 18 & 30 & 56 & 43 & 45 \\
\hline $07 \mathrm{U}$ & $\begin{array}{l}\text { Wolf Creek at Wolf Creek Campground near } \\
\text { Pagosa Springs }\end{array}$ & Upper San Juan & -- & -- & -- & -- & -- & 18 & 30 & 67 & 51 & 53 \\
\hline $08 \mathrm{U}$ & West Fork San Juan River near Pagosa Springs & Upper San Juan & -- & -- & -- & -- & -- & 11 & 34 & 98 & 57 & 56 \\
\hline 09U & San Juan River above Pagosa Springs & Upper San Juan & 36 & 30 & 100 & 75 & 78 & 33 & 52 & 151 & 100 & 100 \\
\hline $10 \mathrm{U}$ & McCabe Creek above Pagosa Springs & Upper San Juan & 16 & 300 & 700 & 432 & 390 & 16 & 470 & 917 & 664 & 575 \\
\hline $11 \mathrm{U}$ & San Juan River at Pagosa Springs & Upper San Juan & -- & -- & -- & -- & -- & 121 & 48 & 523 & 138 & 137 \\
\hline $12 \mathrm{U}$ & San Juan River below Pagosa Springs & Upper San Juan & -- & -- & -- & -- & -- & 10 & 72 & 380 & 212 & 190 \\
\hline $13 \mathrm{U}$ & San Juan River near Carracas & Upper San Juan & -- & -- & -- & -- & -- & 109 & 72 & 758 & 260 & 236 \\
\hline $14 \mathrm{U}$ & San Juan River above Navajo Reservoir & Upper San Juan & 21 & 187 & 63 & 190 & 350 & -- & -- & -- & -- & -- \\
\hline $15 \mathrm{U}$ & East Fork Piedra River below Piedra Falls & Piedra & 11 & 26 & 56 & 45 & 44 & 12 & 36 & 84 & 53 & 48 \\
\hline
\end{tabular}


Table 4. Statistical summary for dissolved solids and specific conductance data for sites with 10 or more samples in the Dolores, Upper San Juan, and Lower San Juan River Basins, southwestern Colorado, 1990-2005. - Continued

[Site ID, number identifying location on figure 1; mg/L, milligrams per liter; $\mu \mathrm{S} / \mathrm{cm}$, microsiemens per centimeter at 25 degrees Celsius; No., number of samples; Min, minimum value; Max, maximum value; Med, median value; --, no value; Agency ID was added in parenthesis to the site name when sites had identical names; WWTP, wastewater treatment plant; gray shaded column indicates statistic that was used for comparison to National water-quality standards and values shown in red represent instances when water-quality standard was not met]

\begin{tabular}{|c|c|c|c|c|c|c|c|c|c|c|c|c|}
\hline \multirow{2}{*}{$\begin{array}{c}\text { Site } \\
\text { ID }\end{array}$} & \multirow{2}{*}{ Site name } & \multirow{2}{*}{ Subbasin name } & \multicolumn{5}{|c|}{ Dissolved solids, in mg/L } & \multicolumn{5}{|c|}{ Specific conductance, in $\mu \mathrm{S} / \mathrm{cm}$} \\
\hline & & & Number & Minimum & Maximum & Mean & Median & Number & Minimum & Maximum & Mean & Median \\
\hline \multicolumn{13}{|c|}{ Upper San Juan River Basin-Continued } \\
\hline $16 \mathrm{U}$ & Piedra River at Highway 160 & Piedra & 50 & 59 & 550 & 230 & 245 & 51 & 93 & 815 & 336 & 347 \\
\hline $17 \mathrm{U}$ & Stollsteimer Creek at Highway 151 & Piedra & 17 & 340 & 840 & 652 & 680 & 18 & 487 & 1,144 & 876 & 915 \\
\hline $18 \mathrm{U}$ & Piedra River near Arboles & Piedra & -- & -- & -- & -- & -- & 118 & 89 & 626 & 290 & 289 \\
\hline $19 \mathrm{U}$ & Piedra River northeast of Arboles & Piedra & 22 & 194 & 66 & 180 & 350 & -- & -- & -- & -- & -- \\
\hline $20 \mathrm{U}$ & $\begin{array}{l}\text { Los Pinos River above Vallecito Reservoir near } \\
\text { Bayfield }\end{array}$ & Upper San Juan & -- & -- & -- & -- & -- & 17 & 43 & 107 & 73 & 71 \\
\hline $21 \mathrm{U}$ & Los Pinos River above Vallecito Reservoir & Upper San Juan & 47 & 34 & 2,710 & 118 & 63 & 51 & 48 & 129 & 93 & 97 \\
\hline $22 \mathrm{U}$ & Vallecito Creek near Bayfield & Upper San Juan & 185 & 20 & 65 & 36 & 36 & 164 & 34 & 112 & 65 & 63 \\
\hline $23 \mathrm{U}$ & Vallecito Creek near mouth & Upper San Juan & 47 & 22 & 69 & 48 & 47 & 52 & 43 & 112 & 79 & 82 \\
\hline $24 \mathrm{U}$ & $\begin{array}{l}\text { Los Pinos River below Vallecito Reservoir near } \\
\text { Bayfield }\end{array}$ & Upper San Juan & -- & -- & -- & -- & -- & 15 & 64 & 135 & 86 & 78 \\
\hline $25 \mathrm{U}$ & Wallace Gulch at 502 Road north of Bayfield & Upper San Juan & 14 & 81 & 250 & 177 & 195 & 16 & 134 & 449 & 296 & 310 \\
\hline $26 \mathrm{U}$ & Los Pinos River near Ignacio & Upper San Juan & -- & -- & -- & -- & -- & 35 & 80 & 280 & 181 & 175 \\
\hline $27 \mathrm{U}$ & Spring Creek at La Boca & Upper San Juan & -- & -- & -- & -- & -- & 100 & 245 & 1,290 & 614 & 479 \\
\hline $28 \mathrm{U}$ & Los Pinos River near La Boca & Upper San Juan & 10 & 134 & 90 & 130 & 220 & -- & -- & -- & -- & -- \\
\hline $29 \mathrm{U}$ & Los Pinos River at La Boca & Upper San Juan & -- & -- & -- & -- & -- & 108 & 106 & 436 & 238 & 227 \\
\hline $30 \mathrm{U}$ & La Plata at Hesperus & Middle San Juan & 38 & 63 & 140 & 107 & 110 & 19 & 104 & 198 & 166 & 168 \\
\hline $31 \mathrm{U}$ & Spring Creek near Breen & Middle San Juan & 12 & 230 & 340 & 268 & 255 & 10 & 338 & 492 & 417 & 420 \\
\hline $32 \mathrm{U}$ & East Fork Mancos River at 44 Road & Mancos & 20 & 88 & 310 & 212 & 225 & 17 & 125 & 434 & 292 & 322 \\
\hline $33 \mathrm{U}$ & Mancos River at Mancos & Mancos & 13 & 198 & 100 & 190 & 320 & -- & -- & -- & -- & -- \\
\hline $34 \mathrm{U}$ & Chicken Creek at Mancos & Mancos & 16 & 270 & 1490 & 777 & 490 & 16 & 278 & 1,740 & 903 & 708 \\
\hline $35 \mathrm{U}$ & Mancos River near Towaoc & Mancos & -- & -- & -- & -- & -- & 111 & 362 & 2,656 & 1,382 & 1,450 \\
\hline $36 \mathrm{U}$ & Navajo Wash near Towaoc & Mancos & -- & -- & -- & -- & -- & 47 & 773 & 8,670 & 3,411 & 1,990 \\
\hline \multicolumn{13}{|c|}{ Lower San Juan River Basin } \\
\hline $01 \mathrm{~L}$ & $\begin{array}{l}\text { McElmo Creek above Cortez Sanitation District, } \\
\text { Southwest WWTP }\end{array}$ & McElmo & 14 & 940 & 4,010 & 2,790 & 3,385 & 14 & 1,057 & 4,417 & 3,020 & 3,577 \\
\hline $02 \mathrm{~L}$ & Mud Creek at State Highway 32, near Cortez & McElmo & 119 & 1,090 & 10,200 & 2,849 & 1,760 & 125 & 1,510 & 10,659 & 3,451 & 2,410 \\
\hline $03 \mathrm{~L}$ & McElmo Creek near Cortez & McElmo & 42 & 1,010 & 3,450 & 1,864 & 1,525 & 42 & 1,430 & 3,490 & 2,174 & 1,935 \\
\hline $04 \mathrm{~L}$ & McElmo Creek above Trail Canyon near Cortez & McElmo & 129 & 784 & 3,090 & 1,651 & 1,340 & 139 & 1,139 & 3,330 & 2,122 & 1,880 \\
\hline $05 \mathrm{~L}$ & McElmo Creek above Trail Canyon at gage & McElmo & 41 & 840 & 3,100 & 2,027 & 2,340 & 42 & 169 & 3,421 & 2,101 & 2,253 \\
\hline $06 \mathrm{~L}$ & McElmo Creek near Colorado-Utah State Line & McElmo & 156 & 727 & 3,280 & 1,867 & 1,750 & 176 & 1,063 & 3,640 & 2,333 & 2,396 \\
\hline
\end{tabular}



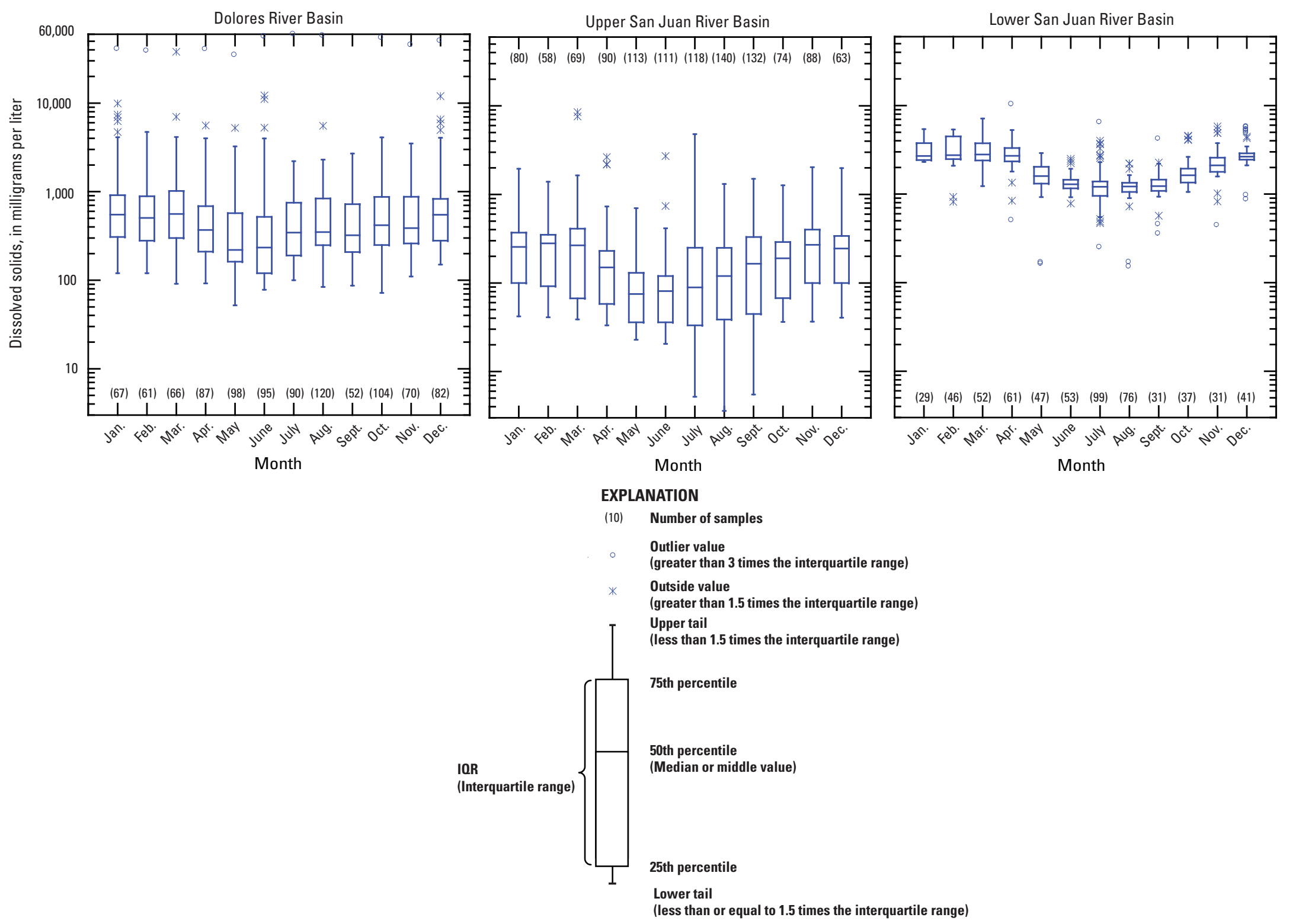

Figure 6. Graph showing monthly distribution of instantaneous dissolved-solids concentrations in surface water in the Dolores, Upper San Juan, and Lower San Juan River Basins, southwestern Colorado, 1990-2005 
Table 5. Summary of trend analysis results for dissolved-solids concentrations and specific-conductance values at selected sites in the Dolores, Upper San Juan, and Lower San Juan River Basins, southwestern Colorado, 1993-2003.

[Site ID, site identification number shown on figure 1; USGS ID, U.S. Geological Survey identification number; mg/L, milligrams per liter; $\mu$ S/cm, microsiemens per centimeter at 25 degrees Celsius; p-value, probability value; nt, not a significant trend; statistically significant trend at p-value less than or equal to 0.05 ; “--", available data did not meet the selection criteria; typical value is the median value for the trend analysis period; yr, year]

\begin{tabular}{|c|c|c|c|c|c|c|c|c|c|c|c|c|}
\hline \multirow{3}{*}{ Site ID } & \multirow{3}{*}{ USGS ID } & \multirow{3}{*}{ Site name } & \multicolumn{5}{|c|}{ Dissolved solids } & \multicolumn{5}{|c|}{ Specific conductance } \\
\hline & & & \multirow{2}{*}{$\begin{array}{c}\text { Typical } \\
\text { value } \\
\text { (mg/L) }\end{array}$} & \multirow[b]{2}{*}{ Trend } & \multirow{2}{*}{$\begin{array}{c}\text { p- } \\
\text { value }\end{array}$} & \multicolumn{2}{|c|}{ Trend slope } & \multirow{2}{*}{$\begin{array}{c}\text { Typical } \\
\text { value } \\
(\mu \mathrm{S} / \mathrm{cm})\end{array}$} & \multirow[b]{2}{*}{ Trend } & \multirow[b]{2}{*}{$\mathrm{p}$-value } & \multicolumn{2}{|c|}{ Trend slope } \\
\hline & & & & & & (percent) & $\begin{array}{l}\text { (mg/L } \\
\text { per yr) }\end{array}$ & & & & (percent) & $\begin{array}{l}(\mu \mathrm{S} / \mathrm{cm} \\
\text { per yr) }\end{array}$ \\
\hline \multicolumn{13}{|c|}{ Dolores River Basin } \\
\hline $28 \mathrm{D}$ & 09172500 & San Miguel River near Placerville & -- & -- & -- & -- & -- & $\mathrm{nt}$ & nt & $\mathrm{nt}$ & $\mathrm{nt}$ & nt \\
\hline $33 \mathrm{D}$ & 09177000 & San Miguel River at Uravan & -- & -- & -- & -- & -- & $\mathrm{nt}$ & $\mathrm{nt}$ & $\mathrm{nt}$ & $\mathrm{nt}$ & $\mathrm{nt}$ \\
\hline 06D & 09165000 & Dolores River below Rico & -- & -- & -- & -- & -- & $\mathrm{nt}$ & $\mathrm{nt}$ & $\mathrm{nt}$ & $\mathrm{nt}$ & $\mathrm{nt}$ \\
\hline $10 \mathrm{D}$ & 09166500 & Dolores River at Dolores & -- & -- & -- & -- & -- & $\mathrm{nt}$ & $\mathrm{nt}$ & $\mathrm{nt}$ & $\mathrm{nt}$ & $\mathrm{nt}$ \\
\hline $16 \mathrm{D}$ & 09169500 & Dolores River at Bedrock & $\mathrm{nt}$ & $\mathrm{nt}$ & $\mathrm{nt}$ & $\mathrm{nt}$ & $\mathrm{nt}$ & $\mathrm{nt}$ & $\mathrm{nt}$ & $\mathrm{nt}$ & $\mathrm{nt}$ & $\mathrm{nt}$ \\
\hline 19D & 09171100 & Dolores River near Bedrock & 1,230 & down & 0.013 & -8.3 & -101.5 & 2,260 & down & 0.005 & -8.9 & -201.8 \\
\hline \multicolumn{13}{|c|}{ Upper San Juan River Basin } \\
\hline $08 \mathrm{~A}$ & 09358000 & Animas River at Silverton & -- & -- & -- & -- & -- & $\mathrm{nt}$ & $\mathrm{nt}$ & $\mathrm{nt}$ & nt & $\mathrm{nt}$ \\
\hline $17 \mathrm{~A}$ & 09358550 & Cement Creek at Silverton & -- & -- & -- & -- & -- & $\mathrm{nt}$ & $\mathrm{nt}$ & $\mathrm{nt}$ & $\mathrm{nt}$ & $\mathrm{nt}$ \\
\hline $31 \mathrm{~A}$ & 09359010 & Mineral Creek at Silverton & -- & -- & -- & -- & -- & $\mathrm{nt}$ & $\mathrm{nt}$ & $\mathrm{nt}$ & $\mathrm{nt}$ & $\mathrm{nt}$ \\
\hline $45 \mathrm{~A}$ & 09361500 & Animas River at Durango & -- & -- & -- & -- & -- & $\mathrm{nt}$ & $\mathrm{nt}$ & $\mathrm{nt}$ & $\mathrm{nt}$ & $\mathrm{nt}$ \\
\hline $04 \mathrm{U}$ & 09339900 & $\begin{array}{l}\text { East Fork San Juan River above Sand Creek, near } \\
\text { Pagosa Springs }\end{array}$ & -- & -- & -- & -- & -- & $\mathrm{nt}$ & $\mathrm{nt}$ & $\mathrm{nt}$ & $\mathrm{nt}$ & $\mathrm{nt}$ \\
\hline $11 \mathrm{U}$ & 09342500 & San Juan River at Pagosa Springs & -- & -- & -- & -- & -- & $\mathrm{nt}$ & nt & nt & $\mathrm{nt}$ & nt \\
\hline $13 \mathrm{U}$ & 09346400 & San Juan River near Carracas & -- & -- & -- & -- & -- & $\mathrm{nt}$ & $\mathrm{nt}$ & $\mathrm{nt}$ & $\mathrm{nt}$ & $\mathrm{nt}$ \\
\hline $18 \mathrm{U}$ & 09349800 & Piedra River near Arboles & -- & -- & -- & -- & -- & $\mathrm{nt}$ & $\mathrm{nt}$ & $\mathrm{nt}$ & nt & $\mathrm{nt}$ \\
\hline $22 \mathrm{U}$ & 09352900 & Vallecito Creek near Bayfield & $\mathrm{nt}$ & $\mathrm{nt}$ & $\mathrm{nt}$ & $\mathrm{nt}$ & $\mathrm{nt}$ & $\mathrm{nt}$ & $\mathrm{nt}$ & $\mathrm{nt}$ & nt & $\mathrm{nt}$ \\
\hline $27 \mathrm{U}$ & 09355000 & Spring Creek at La Boca & -- & -- & -- & -- & -- & 431 & down & 0.022 & -3.3 & -14.0 \\
\hline $29 \mathrm{U}$ & 09354500 & Los Pinos River at La Boca & -- & -- & -- & -- & -- & 233 & down & 0.023 & -1.5 & -3.6 \\
\hline $35 \mathrm{U}$ & 09371000 & Mancos River near Towaoc & -- & -- & -- & -- & -- & 1,610 & down & 0.017 & -4.1 & -66.4 \\
\hline \multicolumn{13}{|c|}{ Lower San Juan River Basin } \\
\hline $02 \mathrm{~L}$ & 09371492 & Mud Creek at State Highway 32, near Cortez & 2,410 & down & 0.033 & -2.2 & -51.9 & $\mathrm{nt}$ & $\mathrm{nt}$ & $\mathrm{nt}$ & $\mathrm{nt}$ & $\mathrm{nt}$ \\
\hline $04 \mathrm{~L}$ & 09371520 & McElmo Creek above Trail Canyon near Cortez & 1,750 & down & 0.029 & -2.4 & -41.8 & 2,170 & down & 0.031 & -3.1 & -66.1 \\
\hline $06 \mathrm{~L}$ & 09372000 & McElmo Creek near Colorado-Utah State line & 1,900 & down & 0.021 & -2.8 & -52.4 & 2,230 & down & 0.011 & -2.3 & -52.0 \\
\hline
\end{tabular}




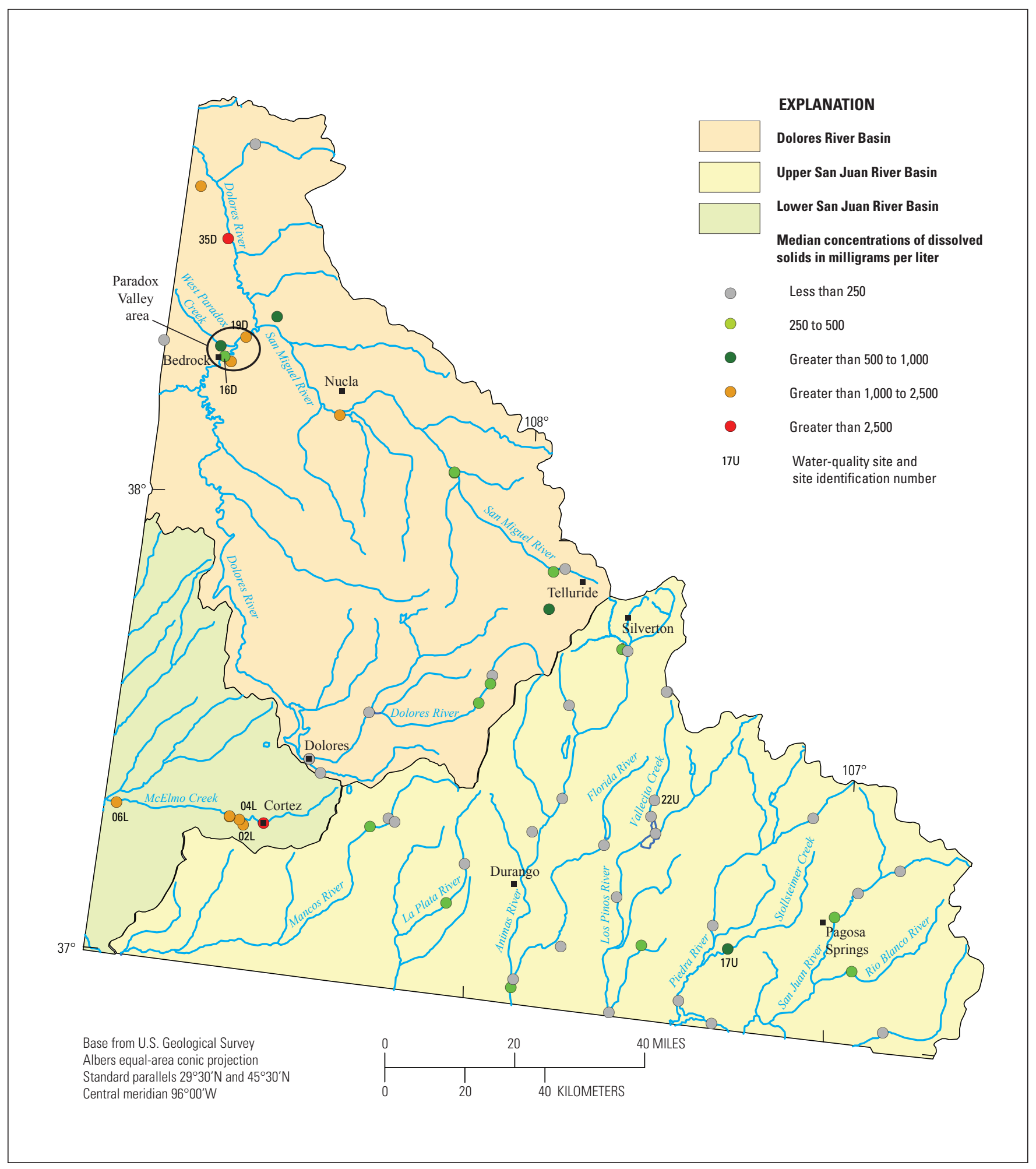

Figure 7. Map showing spatial distribution of median dissolved-solids concentrations in the Dolores, Upper San Juan, and Lower San Juan River Basins, southwestern Colorado, 1990-2005. 
Dissolved-solids concentrations decreased by 8.3 percent, and $\mathrm{SC}$ values decreased by 8.9 percent (table 5 ). These decreases in DS concentrations and SC values are likely because of the operation of the Paradox Valley Unit (described in the Geology section) upstream from the Dolores River near Bedrock site (19D). Chafin (2003) evaluated the effectiveness of the Paradox Valley Unit using data collected from 1988 through September 2001, and the average DS load contributed by the saline inflow to the Dolores River had decreased by about 90 percent by September 30, 2001 compared to the average DS load before the Paradox Valley Unit began production operation. Chafin (2003) also stated that this decrease may have been due, in part, to the lower than average precipitation during the latter part of the analysis period producing less saline inflow to the river. No significant trends in DS concentrations or SC values occurred at any other site in the Dolores River Basin.

Upper San Juan River Basin.-Dissolved-solids data were analyzed at 32 sites. Median DS concentrations ranged from 8 to $680 \mathrm{mg} / \mathrm{L}$ (table 4). Thirty-one of the 32 sites analyzed in the Upper SJRB had median DS concentrations less than $500 \mathrm{mg} / \mathrm{L}$; and many sites had median DS concentrations less than $250 \mathrm{mg} / \mathrm{L}$ (table 4 and fig. 7). Only Stollsteimer Creek at Highway 151 (site 17U) had a median DS concentration greater than $500 \mathrm{mg} / \mathrm{L}$. Vallecito Creek near Bayfield (site 22U) was the only site in the Upper SJRB that had sufficient data to perform trend analyses for DS. No significant trends in DS occurred at the site (table 5). Thirteen sites in the Upper SJRB had sufficient SC data to analyze for trends. Four sites had significant downward trends in $\mathrm{SC}$ values (table 5). Decreases in SC values ranged from 1.1 to 4.1 percent. The largest decrease in SC values of 4.1 percent occurred at the Mancos River near Towaoc site. This decrease may be the result of salinity control modifications done by the Natural Resources Conservation Service (Environmental Quality Improvement Program) and the Bureau of Reclamation (Colorado River Basin Salinity Control Program) as part of the Mancos Valley Salinity Control Project (Natural Resources Conservation Service, 2004). Richards and Leib (2011) reported that significant decreases in DS occurred in the adjacent McElmo Creek basin as a result of salinity control work that began in the mid-1980s.

Lower San Juan River Basin.-Dissolved-solids data were analyzed at 6 sites. All sites were located in the McElmo Creek basin. Median DS concentrations ranged from 1,340 to $3,385 \mathrm{mg} / \mathrm{L}$ (table 4). Dissolved solids and SC data were analyzed for trends at Mud Creek at State Highway 32, near Cortez (02L), McElmo Creek above Trail Canyon near Cortez (04L), and McElmo Creek near Colorado-Utah State line (06L). Downward trends in DS occurred at all three sites and in SC at two sites (table 5). These decreases in DS concentrations and $\mathrm{SC}$ values may be because of irrigation and water-delivery system improvements made by the BOR in the McElmo Creek basin as part Colorado River Basin Salinity
Control Program (Richards and Leib, 2011; Voggesser, 2001). Richards and Leib (2011) reported decreases in salinity (DS) loads in the McElmo Creek basin following salinity control modifications.

\section{Major lons}

Limited major ion data were available with only 13 sites throughout the study area having enough major ion data to determine the relative ionic composition in samples to classify and compare water types (table 6). Three of these sites were located in the Dolores River Basin, seven in the Upper SJRB, and three in the Lower SJRB (table 6). Trends in chloride and sulfate concentrations were analyzed at selected sites with sufficient data from 1993 through 2003. Sufficient data were not available to analyze for trends in other major ion concentrations.

Dolores River Basin.-Dolores River Basin sites were located in close proximity to each other and in an area of transition surrounding the Paradox Valley. In this area, water type varied spatially. Dolores River at Bedrock (site 16D), upstream from the Paradox Valley Unit, showed no dominant water type; whereas, at Dolores River near Bedrock (site 19D), downstream from the Paradox Valley Unit, the dominant cation was sodium/potassium and the dominant anion was chloride. At West Paradox Creek above Bedrock (site 18D), sulfate was the dominant anion and there was no dominant cation (figs. 1 and 8).

Temporal trends in chloride and sulfate concentrations were evaluated at Dolores River at Bedrock and Dolores River near Bedrock sites (table 7). No significant trends in chloride or sulfate concentrations occurred at Dolores River at Bedrock. Downstream from the Paradox Valley Unit at the Dolores River near Bedrock site, a significant decrease of 10.5 percent in chloride concentrations occurred; but no trend in sulfate concentrations occurred (table 7). This decrease of chloride concentration in samples from the Dolores River near Bedrock site is likely because of the operation of the Paradox Valley Unit.

Upper San Juan River Basin.-All seven sites analyzed in the Upper SJRB had calcium as the dominant cation. The dominant anion varied depending on location of the site (fig. 8). Sites located in the upper Animas River Basin near the headwaters tended to have sulfate as the dominant anion; whereas, the two sites located outside of the Animas River Basin [Los Pinos River above Vallecito Reservoir near Bayfield (site 20U) and Vallecito Creek near Bayfield (site 22U)] had bicarbonate as the dominant anion. Only the Vallecito Creek near Bayfield site had sufficient data to perform trend analyses for chloride and sulfate (table 7). No significant trends in chloride concentrations occurred at the site; however, a significant upward trend in sulfate concentrations of 4.0 percent was measured. This trend in sulfate concentrations may be related to the drought conditions 
Table 6. Average major ion concentrations at selected sites in the Dolores, Upper San Juan, and Lower San Juan River Basins, southwestern Colorado, $1990-2005$.

[Site ID, site identification number on figure 1; USGS ID, U.S. Geological Survey identification number; N, number of samples; Ca, calcium; Mg, magnesium; Na, sodium; K, potassium; CO ${ }_{3}$, carbonate; $\mathrm{HCO}_{3}$, bicarbonate; $\mathrm{C}_{1}$, chloride; $\mathrm{SO}_{4}$, sulfate; DS, dissolved solids; e, estimated; average concentrations are given in milligrams per liter]

\begin{tabular}{|c|c|c|c|c|c|c|c|c|c|c|c|c|}
\hline Site ID & USGS ID & Site name & $\mathbf{N}$ & Ca & Mg & $\mathrm{Na}$ & $\mathbf{K}$ & $\mathrm{CO}_{3}$ & $\mathrm{HCO}_{3}$ & $C_{1}$ & $\mathrm{SO}_{4}$ & DS \\
\hline \multicolumn{13}{|c|}{ Dolores River Basin } \\
\hline 16D & 09169500 & Dolores River at Bedrock & 18 & 67.7 & 17.7 & 76.1 & 4.3 & 8.73 & 139 & 96.9 & 141 & 485 \\
\hline $18 \mathrm{D}$ & 09170800 & West Paradox Creek above Bedrock & 12 & 98.6 & 54.3 & 27.0 & 3.2 & 27.5 & 218 & 26.3 & 260 & 615 \\
\hline 19D & 09171100 & Dolores River near Bedrock & 20 & 80.5 & 26.4 & 371 & 19.8 & 8.22 & 148 & 609 & 194 & 1,385 \\
\hline \multicolumn{13}{|c|}{ Upper San Juan River Basin } \\
\hline $26 \mathrm{~A}$ & 375028107455801 & A43 Paradise Basin above confluence above mines & 1 & 89.0 & 5.2 & 3.0 & 0.3 & $\mathrm{e} 0.0001$ & 6.1 & 0.1 & 240 & 389 \\
\hline $27 \mathrm{~A}$ & 375039107444801 & W39 Middle Fork above Red tributary & 1 & 140 & 9.0 & 4.2 & 0.5 & $\mathrm{e} 0.002$ & 23.0 & 0.4 & 430 & 603 \\
\hline $28 \mathrm{~A}$ & 375042107443801 & W41 Sheep Lake Tributary at confluence with Middle Fork & 1 & 25.0 & 1.4 & 0.7 & 0.4 & $\mathrm{e} 0.18$ & 47.0 & 0.1 & 28.0 & 82 \\
\hline $33 \mathrm{~A}$ & 09359020 & Animas River below Silverton & 31 & 52.4 & 3.4 & 2.2 & 0.6 & $\mathrm{e} 0.002$ & 13.5 & 0.8 & 134 & 229 \\
\hline $58 \mathrm{~A}$ & 375044107440601 & W38 Stream below W16 & 1 & 30.0 & 3.1 & 3.6 & 0.4 & $\mathrm{e} 0.005$ & 21.0 & 0.2 & 68.0 & 137 \\
\hline $20 \mathrm{U}$ & 09352800 & Los Pinos River above Vallecito Reservoir near Bayfield & 1 & 16.6 & 2.4 & 2.0 & 1.2 & $\mathrm{e} 0.088$ & 61.0 & 1.0 & 3.7 & 65.1 \\
\hline $22 \mathrm{U}$ & 09352900 & Vallecito Creek near Bayfield & 51 & 8.2 & 1.8 & 0.8 & 0.5 & 0.02 & 26.0 & 0.4 & 7.1 & 37.2 \\
\hline \multicolumn{13}{|c|}{ Lower San Juan River Basin } \\
\hline $02 \mathrm{~L}$ & 09371492 & Mud Creek at State Highway 32, near Cortez & 18 & 305 & 240 & 373 & 7.5 & 13.4 & 346 & 65.3 & 1,993 & 3,174 \\
\hline $04 \mathrm{~L}$ & 09371520 & McElmo Creek above Trail Canyon near Cortez & 19 & 266 & 132 & 126 & 5.6 & 15.6 & 272 & 29.6 & 1,109 & 1,829 \\
\hline $06 \mathrm{~L}$ & 09372000 & McElmo Creek near Colorado-Utah State line & 20 & 270 & 144 & 146 & 5.8 & 16.3 & 302 & 32.2 & 1,199 & 1,970 \\
\hline
\end{tabular}


Table 7. Summary of trend analysis results for chloride, sulfate, and nitrate plus nitrite concentrations for selected sites in the Dolores, Upper San Juan, and Lower San River Basins, southwestern Colorado, 1993-2003.

[Site ID, identification number shown on figure 1; USGS ID; U.S. Geological Survey identification number; mg/L, milligrams per liter; p-value, probability value; nt, not a significant trend; statistically significant trend at p-value less than or equal to 0.05 ; “--", available data did not meet the selection criteria; typical value is the median value for the trend analysis period; yr, year]

\begin{tabular}{|c|c|c|c|c|c|c|c|c|c|c|c|c|c|c|c|c|c|}
\hline \multirow{3}{*}{$\begin{array}{l}\text { Site } \\
\text { ID }\end{array}$} & \multirow{3}{*}{ USGS ID } & \multirow{3}{*}{ Site name } & \multicolumn{5}{|c|}{ Chloride, filtered } & \multicolumn{5}{|c|}{ Sulfate, filtered } & \multicolumn{5}{|c|}{ Nitrate plus nitrite, filtered } \\
\hline & & & \multirow[b]{2}{*}{$\begin{array}{l}\text { Typical } \\
\text { value } \\
\text { (mg/L) }\end{array}$} & \multirow[b]{2}{*}{ Trend } & \multirow[b]{2}{*}{$\begin{array}{c}\text { p- } \\
\text { value }\end{array}$} & \multicolumn{2}{|c|}{ Trend slope } & \multirow[b]{2}{*}{$\begin{array}{l}\text { Typical } \\
\text { value } \\
\text { (mg/L) }\end{array}$} & \multirow[b]{2}{*}{ Trend } & \multirow[b]{2}{*}{$\begin{array}{c}\mathbf{p}- \\
\text { value }\end{array}$} & \multicolumn{2}{|c|}{ Trend slope } & \multirow[b]{2}{*}{$\begin{array}{l}\text { Typical } \\
\text { value } \\
\text { (mg/L) }\end{array}$} & \multirow[b]{2}{*}{ Trend } & \multirow[b]{2}{*}{$\begin{array}{c}\text { p- } \\
\text { value }\end{array}$} & \multicolumn{2}{|c|}{ Trend slope } \\
\hline & & & & & & $\begin{array}{l}\text { (per- } \\
\text { cent) }\end{array}$ & $\begin{array}{l}\text { (mg/L } \\
\text { per yr) }\end{array}$ & & & & $\begin{array}{l}\text { (per- } \\
\text { cent) }\end{array}$ & $\begin{array}{c}\text { (mg/L } \\
\text { per } \\
\text { yr) }\end{array}$ & & & & $\begin{array}{l}\text { (per- } \\
\text { cent) }\end{array}$ & $\begin{array}{c}\text { (mg/L } \\
\text { per } \\
\text { yr) }\end{array}$ \\
\hline \multicolumn{18}{|c|}{ Dolores River Basin } \\
\hline $16 \mathrm{D}$ & 09169500 & Dolores River at Bedrock & $\mathrm{nt}$ & $\mathrm{nt}$ & $\mathrm{nt}$ & $\mathrm{nt}$ & $\mathrm{nt}$ & $\mathrm{nt}$ & $\mathrm{nt}$ & $\mathrm{nt}$ & $\mathrm{nt}$ & $\mathrm{nt}$ & -- & -- & -- & -- & -- \\
\hline 19D & 09171100 & Dolores River near Bedrock & 566 & down & 0.013 & -10.5 & -59.4 & $\mathrm{nt}$ & $\mathrm{nt}$ & $\mathrm{nt}$ & $\mathrm{nt}$ & $\mathrm{nt}$ & -- & -- & -- & -- & -- \\
\hline \multicolumn{18}{|c|}{ Upper San Juan River Basin } \\
\hline $22 \mathrm{U}$ & 09352900 & Vallecito Creek near Bayfield & $\mathrm{nt}$ & $\mathrm{nt}$ & $\mathrm{nt}$ & $\mathrm{nt}$ & $\mathrm{nt}$ & 6.2 & up & 0.040 & 4.0 & 0.2 & $\mathrm{nt}$ & $\mathrm{nt}$ & $\mathrm{nt}$ & $\mathrm{nt}$ & $\mathrm{nt}$ \\
\hline \multicolumn{18}{|c|}{ Lower San Juan River Basin } \\
\hline $02 \mathrm{~L}$ & 09371492 & Mud Creek at State Highway 32, near Cortez & $\mathrm{nt}$ & $\mathrm{nt}$ & $\mathrm{nt}$ & $\mathrm{nt}$ & $\mathrm{nt}$ & 1,530 & down & 0.022 & -2.3 & -35.5 & -- & -- & -- & -- & -- \\
\hline $04 \mathrm{~L}$ & 09371520 & McElmo Creek above Trail Canyon near Cortez & $\mathrm{nt}$ & $\mathrm{nt}$ & $\mathrm{nt}$ & $\mathrm{nt}$ & $\mathrm{nt}$ & 1,070 & down & 0.022 & -2.6 & -28.0 & -- & -- & -- & -- & -- \\
\hline $06 \mathrm{~L}$ & 09372000 & McElmo Creek near Colorado-Utah State line & 27.8 & down & 0.024 & -2.4 & -0.7 & 1,180 & down & 0.020 & -2.9 & -34.4 & -- & -- & -- & -- & -- \\
\hline
\end{tabular}


during the latter part of the analysis period. Additional study, however, would be needed to determine the cause of the change in sulfate concentrations at the site.

Lower San Juan River Basin.-Sufficient major ion data were available to classify water type for three sites in the Lower SJRB. These sites were all located in the McElmo Creek basin. There was no dominant cation; and sulfate was the dominant anion in samples from all three sites (fig. 8). Downward trends in sulfate concentrations ranging from 2 to 3 percent occurred at all three sites (table 7). Only the McElmo Creek near Colorado-Utah State line (06L) site showed a significant downward trend in chloride concentrations (1993-2003). Downward trends of 2.4 percent in chloride concentrations and 2.9 percent in sulfate concentrations occurred at the McElmo Creek near Colorado-Utah State line site. These downward trends in chloride and sulfate concentrations may be because of irrigation and water-delivery system improvements made by the BOR in the McElmo Creek basin as part of the Colorado River Basin Salinity Control Program (Richards and Leib, 2011; Voggesser, 2001).

\section{Trace Elements}

The occurrence and distribution of aluminum, iron, mercury, lead, zinc, and selenium are discussed in this section and its subsections. Median and 85th percentile trace element concentrations were calculated for sites with 10 or more samples. The median concentration for total recoverable metals and the 85th percentile concentration for dissolved metals were compared to applicable State aquatic-life waterquality criteria to provide some context to the existing water-quality data. Water-quality criteria for select constituents were reported as table values (Colorado Department of Public Health and Environment, 2010b) and required computation

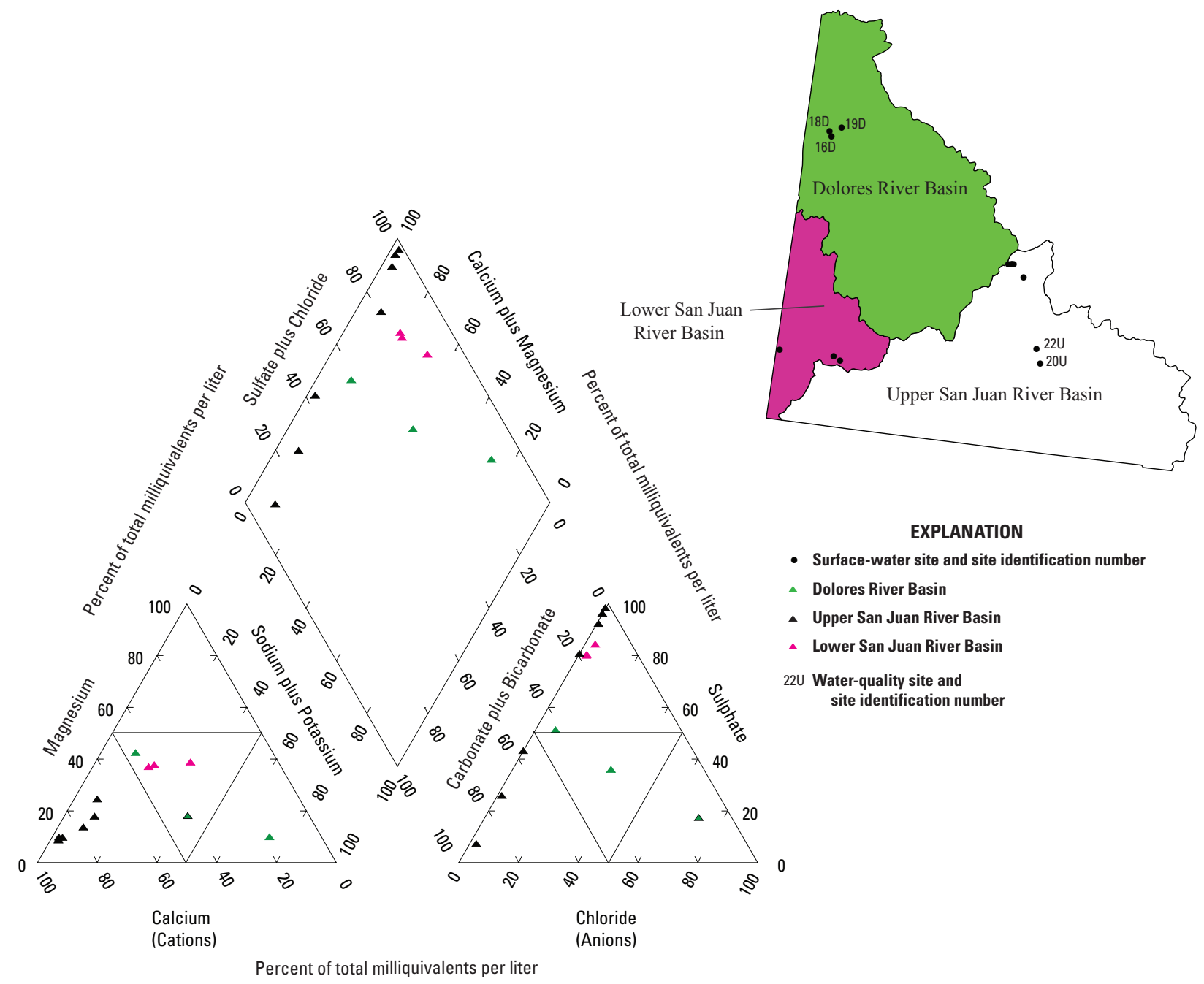

Figure 8. Piper diagram and location map showing water types for selected surface-water sites in the Dolores, Upper San Juan, and Lower San Juan River Basins, southwestern Colorado, 1990-2005. 
based on hardness values as described in the "Selection and Processing of Data" section of the report. Extensive studies have been conducted by Church and others (1997) and Church and others (2007) regarding the occurrence, distribution, and sources of metals in the Animas River Basin.

\section{Aluminum}

In southwestern Colorado, 85th percentile concentrations for dissolved aluminum in surface-water samples ranged from less than 50 to $67,000 \mu \mathrm{g} / \mathrm{L}$; and median total recoverable aluminum concentrations ranged from 57 to $2,000 \mu \mathrm{g} / \mathrm{L}$ (table 8). Colorado State acute and chronic criteria for aluminum were based on total recoverable aluminum concentrations (Colorado Department of Public Health and Environment, 2010b). Total recoverable aluminum concentrations were analyzed in the Upper SJRB only. About twice as many samples were analyzed for dissolved aluminum than total recoverable aluminum, and more sites throughout the study area were sampled and analyzed for dissolved aluminum than total recoverable aluminum. The total recoverable aluminum concentration includes the dissolved fraction (that is, the dissolved aluminum concentration); therefore, if the dissolved aluminum concentration exceeds the criteria, the total recoverable aluminum concentration will also exceed the criteria. For these reasons, the 85th percentile concentrations of dissolved aluminum were calculated for sites with 10 or more samples and compared to Colorado State criteria for aluminum to provide a general overview of existing waterquality conditions.

Colorado State aquatic life acute and chronic criteria for total recoverable aluminum are, for the most part, hardness based; however, in some instances, the Commission established site-specific criteria and(or) $\mathrm{pH}$ dependent criteria. Overall, the acute criteria for total recoverable aluminum ranged from 512 to $10,071 \mu \mathrm{g} / \mathrm{L}$; and the chronic criteria ranged from 73 to $1,438 \mu \mathrm{g} / \mathrm{L}$ at hardness concentrations of 25 to $220 \mathrm{mg} / \mathrm{L}$, respectively (Colorado Department of Public Health and Environment, 2010b). The upper bound of hardness calculations was $220 \mathrm{mg} / \mathrm{L}$ for total recoverable aluminum, rather than the standard $400 \mathrm{mg} / \mathrm{L}$ for other metals equations (Colorado Department of Public Health and Environment, 2010b). The Commission published acute and chronic standards by month for total recoverable aluminum for several segments in the upper Animas River Basin (Colorado Department of Public Health and Environment, 2010a).

Dolores River Basin.-Dissolved aluminum concentrations were analyzed at 11 sites (table 8 and fig. 9). Reporting limits for dissolved aluminum varied from less than 50 to less than $5,000 \mu \mathrm{g} / \mathrm{L}$. Six of the 11 sites had 80 percent or more censored data. For sites with less than 80 percent censored data, 85th percentile concentrations of dissolved aluminum ranged from 61 to $210 \mu \mathrm{g} / \mathrm{L}$ (table 8). Though none of the dissolved data exceeded the State standards, the total concentrations are unknown. No trends in aluminum concentrations were analyzed because of insufficient data.

Upper San Juan River Basin.-Dissolved aluminum concentrations were analyzed at 44 sites in the Upper SJRB (table 8). Only 2 sites had 85 th percentile concentrations of dissolved aluminum (used as surrogate for total recoverable aluminum) that exceeded the acute hardness-based criteria, and 11 sites had 85th percentile concentrations of dissolved aluminum that exceeded the chronic hardness-based criteria. All of the sites that exceeded the acute criteria and all but one site that exceeded the chronic criteria were located in the Cement and Mineral Creek basins north of Silverton (fig. 9). The one site [Sand Creek at Mouth above East Fork San Juan River (site 05U)] outside of the upper Animas River Basin that exceeded criteria was located at the confluence of Sand Creek and the East Fork of the San Juan River upstream from Pagosa Springs. This site had an 85th percentile dissolved aluminum concentration of $93 \mu \mathrm{g} / \mathrm{L}$; whereas, the hardness-based chronic criterion was $81 \mu \mathrm{g} / \mathrm{L}$. Neither of the two sites with adequate data indicated trends in dissolved aluminum concentrations (table 9).

Lower San Juan River Basin. - Dissolved aluminum concentrations were analyzed at two sites (McElmo Creek above Cortez Sanitation District, Southwest WWTP and McElmo Creek above Trail Canyon at gage) in the Lower SJRB (table 8). More than 90 percent of the data at both sites were censored. Reporting limits generally ranged from 30 to $2,500 \mu \mathrm{g} / \mathrm{L}$. A dissolved aluminum concentration of $12 \mu \mathrm{g} / \mathrm{L}$ was measured in 1 of the 15 samples collected at McElmo Creek above Cortez Sanitation District, Southwest WWTP. The remaining 14 samples were coded as less than the reporting limit. A dissolved aluminum concentration of $2.9 \mu \mathrm{g} / \mathrm{L}$ was measured in 1 of the 45 samples collected (1990-2005) at McElmo Creek above Trail Canyon at gage. The remaining 44 samples were coded as less than the reporting limit. Because of insufficient data, aluminum concentrations were not compared to State standards, and trends in aluminum concentrations were not evaluated.

\section{Iron}

Within the study area, median total recoverable iron concentrations ranged from 1.6 to $225,000 \mu \mathrm{g} / \mathrm{L}$ (table 8). It was common for total recoverable iron concentrations to vary over several orders of magnitude at a given site. The highest median total recoverable iron concentrations in the study area generally occurred at sites in the Cement Creek and Mineral Creek Basins in the Upper SJRB north and west of Silverton. The chronic aquatic-life criterion for total recoverable iron was $1,000 \mu \mathrm{g} / \mathrm{L}$ throughout most of the study area except for several segments where the Commission adopted different standards based on site-specific conditions: no acute 
Table 8. Summary of selected trace element concentrations at sites with 10 or more samples in the Dolores, Upper San Juan, and Lower San Juan River Basins, southwestern Colorado, 1990-2005.

[Site ID, site identification number shown on figure 1; Database ID, data repository identification number; $<$, less than; concentrations are given in micrograms per liter; K-M flipped, Kaplan-Meier method modified for left-censored data used to compute summary statistics; ROS, the robust "regression on order statistics" method used to compute summary statistics; Estimate, summary statistics were reported as less than the maximum reporting limit; N, number of samples; NC, number of samples with concentrations reported as less than the reporting limit; Min, minimum value; Max, maximum value; Med, median; $\mathrm{C}_{85}$, 85th percentile concentration; Al.wf, dissolved aluminum; Al.wu, total recoverable aluminum; Fe.wf, dissolved iron; Fe.wu, total recoverable iron; Hg.wf, dissolved mercury; Hg.wu, total recoverable mercury; Pb.wf, dissolved lead; Pb.wu, total recoverable lead; Se.wf, dissolved selenium; Se.wu, total recoverable selenium; Ur.wf, dissolved uranium; Zn.wf, dissolved zinc; Zn.wu, total recoverable zinc; WWTP, wastewater treatment plant; values shown in blue indicate that chronic State water-quality standards were not met and values shown in red indicate that acute and chronic State water-quality standards were not met]

\begin{tabular}{|c|c|c|c|c|c|c|c|c|c|c|c|}
\hline $\begin{array}{l}\text { Site } \\
\text { ID }\end{array}$ & $\begin{array}{c}\text { Database } \\
\text { ID }\end{array}$ & Site name & $\begin{array}{c}\text { Subbasin } \\
\text { name }\end{array}$ & $\begin{array}{c}\text { Con- } \\
\text { stituent }\end{array}$ & Method & $\mathbf{N}$ & NC & Min & Max & Med & $\mathrm{C}_{85}$ \\
\hline \multicolumn{12}{|c|}{ Dolores River Basin } \\
\hline 01D & 10784R & Coal Creek at FR 535 below Lizard Head Wilderness Area & Upper Dolores & Al.wf & Estimate & 10 & 8 & $<50$ & $<50$ & $<50$ & $<50$ \\
\hline $02 \mathrm{D}$ & 10782 & Horse Creek at Highway 145 & Upper Dolores & Al.wf & ROS & 12 & 8 & $<50$ & 62 & 24 & 62 \\
\hline 04D & 10780 & Silver Creek at Highway 145 & Upper Dolores & Al.wf & ROS & 36 & 26 & $<50$ & 140 & 27 & 61 \\
\hline $05 \mathrm{D}$ & 10716 & Dolores River below Rico & Upper Dolores & Al.wf & ROS & 35 & 28 & $<30$ & 87 & 35 & 63 \\
\hline $08 \mathrm{D}$ & $10901 \mathrm{~A}$ & Lost Canyon Creek near Dolores & Upper Dolores & Al.wf & ROS & 14 & 8 & $<50$ & 510 & 75 & 210 \\
\hline $13 \mathrm{D}$ & 10701 & Dolores River at Dolores above Mcphee Reservoir & Upper Dolores & Al.wf & ROS & 25 & 19 & $<30$ & 300 & 28 & 100 \\
\hline $25 \mathrm{D}$ & 10815 & San Miguel River at Society Turn & San Miguel & Al.wf & Estimate & 60 & 55 & $<30$ & $<250$ & $<250$ & $<250$ \\
\hline $26 \mathrm{D}$ & 10871 & South Fork San Miguel River near mouth & San Miguel & Al.wf & ROS & 12 & 9 & $<50$ & $<500$ & 32 & 65 \\
\hline $30 \mathrm{D}$ & 10860 & McKenzie Creek at mouth above confluence with San Miguel River & San Miguel & Al.wf & Estimate & 17 & 16 & $<50$ & $<500$ & $<500$ & $<500$ \\
\hline $35 \mathrm{D}$ & 10903 & Salt Creek at Highway 141 & Lower Dolores & Al.wf & Estimate & 13 & 13 & $<50$ & $<5,000$ & $<5,000$ & $<5,000$ \\
\hline $36 \mathrm{D}$ & 10915 & West Creek in Unaweep Canyon & Lower Dolores & Al.wf & Estimate & 14 & 12 & $<50$ & $<50$ & $<50$ & $<50$ \\
\hline $01 \mathrm{D}$ & 10784R & Coal Creek at FR 535 below Lizard Head Wilderness Area & Upper Dolores & Fe.wf & K-M flipped & 10 & 2 & $<10$ & 140 & 19 & 32 \\
\hline $02 \mathrm{D}$ & 10782 & Horse Creek at Highway 145 & Upper Dolores & Fe.wf & K-M flipped & 12 & 4 & $<10$ & 76 & 28 & 63 \\
\hline $05 \mathrm{D}$ & 10716 & Dolores River below Rico & Upper Dolores & Fe.wf & K-M flipped & 16 & 4 & $<10$ & 69 & 26 & 59 \\
\hline 08D & $10901 \mathrm{~A}$ & Lost Canyon Creek near Dolores & Upper Dolores & Fe.wf & K-M flipped & 14 & 0 & 37 & 3,400 & 225 & 320 \\
\hline $11 \mathrm{D}$ & DRDOL12T & Dolores River at Dolores & Upper Dolores & Fe.wf & K-M flipped & 10 & 4 & $<3$ & 101 & 20 & 61 \\
\hline $13 \mathrm{D}$ & 10701 & Dolores River at Dolores above Mcphee Reservoir & Upper Dolores & Fe.wf & K-M flipped & 25 & 4 & $<10$ & 180 & 19 & 62 \\
\hline $25 \mathrm{D}$ & 10815 & San Miguel River at Society Turn & San Miguel & Fe.wf & K-M flipped & 30 & 3 & $<10$ & 160 & 50 & 87 \\
\hline $26 \mathrm{D}$ & 10871 & South Fork San Miguel River near mouth & San Miguel & Fe.wf & K-M flipped & 12 & 5 & $<10$ & $<100$ & 12 & 24 \\
\hline $30 \mathrm{D}$ & 10860 & McKenzie Creek at mouth above confluence with San Miguel River & San Miguel & Fe.wf & Estimate & 17 & 16 & $<10$ & $<100$ & $<100$ & $<100$ \\
\hline $35 \mathrm{D}$ & 10903 & Salt Creek at Highway 141 & Lower Dolores & Fe.wf & Estimate & 13 & 13 & $<10$ & $<1,000$ & $<1,000$ & $<1,000$ \\
\hline $01 \mathrm{D}$ & 10784R & Coal Creek at FR 535 below & Upper Dolores & Fe.wu & $Z_{-} \mathrm{M} f \mathrm{in}$ & 10 & 0 & 16 & 730 & 265 & 690 \\
\hline $02 \mathrm{D}$ & 10782 & Horse Creek at Highway 145 & Upper Dolores & Fe.wu & K-M flipped & 12 & 0 & 85 & 1,300 & 220 & 840 \\
\hline $03 \mathrm{D}$ & 10718 & Dolores River above Horse Creek & Upper Dolores & Fe.wu & K-M flipped & 16 & 3 & $<10$ & 780 & 72 & 450 \\
\hline $04 \mathrm{D}$ & 10780 & Silver Creek at Highway 145 & Upper Dolores & Fe.wu & K-M flipped & 47 & 12 & $<10$ & 1,900 & 99 & 760 \\
\hline $05 \mathrm{D}$ & 10716 & Dolores River below Rico & Upper Dolores & Fe.wu & K-M flipped & 48 & 6 & $<10$ & 810 & 115 & 290 \\
\hline 07D & 10770 & West Dolores River near Stoner at Highway 145 & Upper Dolores & Fe.wu & K-M flipped & 19 & 0 & 13 & 7,000 & 100 & 700 \\
\hline 08D & $10901 \mathrm{~A}$ & Lost Canyon Creek near Dolores & Upper Dolores & Fe.wu & K-M flipped & 13 & 0 & 60 & 1,600 & 450 & 870 \\
\hline $11 \mathrm{D}$ & DRDOL12T & Dolores River at Dolores & Upper Dolores & Fe.wu & K-M flipped & 10 & 1 & $<3$ & 696 & 156 & 258 \\
\hline $13 \mathrm{D}$ & 10701 & Dolores River at Dolores above Mcphee Reservoir & Upper Dolores & Fe.wu & K-M flipped & 25 & 0 & 15 & 2,200 & 93 & 580 \\
\hline $20 \mathrm{D}$ & 10818 & San Miguel River above Marshall Creek & San Miguel & Fe.wu & K-M flipped & 11 & 5 & $<10$ & 130 & 10 & 92 \\
\hline $25 \mathrm{D}$ & 10815 & San Miguel River at Society Turn & San Miguel & Fe.wu & K-M flipped & 76 & 2 & $<50$ & 3,300 & 145 & 500 \\
\hline $26 \mathrm{D}$ & 10871 & South Fork San Miguel River near mouth & San Miguel & Fe.wu & K-M flipped & 25 & 1 & $<50$ & 1,200 & 200 & 500 \\
\hline
\end{tabular}


Table 8. Summary of selected trace element concentrations at sites with 10 or more samples in the Dolores, Upper San Juan, and Lower San Juan River Basins, southwestern Colorado, 1990-2005.-Continued

[Site ID, site identification number shown on figure 1; Database ID, data repository identification number; <, less than; concentrations are given in micrograms per liter; K-M flipped, Kaplan-Meier method modified for left-censored data used to compute summary statistics; ROS, the robust "regression on order statistics" method used to compute summary statistics; Estimate, summary statistics were reported as less than the maximum reporting limit; $\mathrm{N}$, number of samples; $\mathrm{NC}$, number of samples with concentrations reported as less than the reporting limit; Min, minimum value; Max, maximum value; Med, median; $\mathrm{C}_{85}$, 85th percentile concentration; Al.wf, dissolved aluminum; Al.wu, total recoverable aluminum; Fe.wf, dissolved iron; Fe.wu, total recoverable iron; Hg.wf, dissolved mercury; Hg.wu, total recoverable mercury; Pb.wf, dissolved lead; Pb.wu, total recoverable lead; Se.wf, dissolved selenium; Se.wu, total recoverable selenium; Ur.wf, dissolved uranium; Zn.wf, dissolved zinc; Zn.wu, total recoverable zinc; WWTP, wastewater treatment plant; values shown in blue indicate that chronic State water-quality standards were not met and values shown in red indicate that acute and chronic State water-quality standards were not met]

\begin{tabular}{|c|c|c|c|c|c|c|c|c|c|c|c|}
\hline $\begin{array}{c}\text { Site } \\
\text { ID }\end{array}$ & $\begin{array}{c}\text { Database } \\
\text { ID }\end{array}$ & Site name & $\begin{array}{c}\text { Subbasin } \\
\text { name }\end{array}$ & $\begin{array}{c}\text { Con- } \\
\text { stituent }\end{array}$ & Method & $\mathbf{N}$ & NC & Min & Max & Med & $\mathrm{C}_{85}$ \\
\hline \multicolumn{12}{|c|}{ Dolores River Basin—Continued } \\
\hline $27 \mathrm{D}$ & 10875 & Howard Fork San Miguel River at Ophir & San Miguel & Fe.wu & K-M flipped & 17 & 0 & 90 & 1,900 & 170 & 660 \\
\hline $30 \mathrm{D}$ & 10860 & McKenzie Creek at mouth above confluence with San Miguel River & San Miguel & Fe.wu & ROS & 17 & 9 & $<10$ & 690 & 4.8 & 24 \\
\hline $32 \mathrm{D}$ & 10831 & Naturita Creek at Naturita & San Miguel & Fe.wu & K-M flipped & 18 & 0 & 38 & 8,300 & 215 & 930 \\
\hline $35 \mathrm{D}$ & 10903 & Salt Creek at Highway 141 & Lower Dolores & Fe.wu & ROS & 13 & 7 & $<1000$ & 4,100 & 142 & 3,500 \\
\hline $36 \mathrm{D}$ & 10915 & West Creek in Unaweep Canyon & Lower Dolores & Fe.wu & K-M flipped & 14 & 0 & 15 & 520 & 97 & 190 \\
\hline 03D & 10718 & Dolores River above Horse Creek & Upper Dolores & Hg.wf & Estimate & 14 & 14 & $<0.1$ & $<0.2$ & $<0.2$ & $<0.2$ \\
\hline 04D & 10780 & Silver Creek at Highway 145 & Upper Dolores & Hg.wf & Estimate & 20 & 19 & $<0.1$ & $<0.2$ & $<0.2$ & $<0.2$ \\
\hline $05 \mathrm{D}$ & 10716 & Dolores River below Rico & Upper Dolores & Hg.wf & Estimate & 28 & 28 & $<0.1$ & $<0.2$ & $<0.2$ & $<0.2$ \\
\hline 07D & 10770 & West Dolores River near Stoner at Highway 145 & Upper Dolores & Hg.wf & Estimate & 13 & 13 & $<0.1$ & $<0.2$ & $<0.2$ & $<0.2$ \\
\hline $13 \mathrm{D}$ & 10701 & Dolores River at Dolores above Mcphee Reservoir & Upper Dolores & Hg.wf & Estimate & 21 & 21 & $<0.1$ & $<0.2$ & $<0.2$ & $<0.2$ \\
\hline $25 \mathrm{D}$ & 10815 & San Miguel River at Society Turn & San Miguel & Hg.wf & Estimate & 53 & 53 & $<0.1$ & $<0.2$ & $<0.2$ & $<0.2$ \\
\hline $26 \mathrm{D}$ & 10871 & South Fork San Miguel River near mouth & San Miguel & Hg.wf & Estimate & 14 & 14 & $<0.1$ & $<0.2$ & $<0.2$ & $<0.2$ \\
\hline $27 \mathrm{D}$ & 10875 & Howard Fork San Miguel River at Ophir & San Miguel & Hg.wf & Estimate & 16 & 16 & $<0.1$ & $<0.2$ & $<0.2$ & $<0.2$ \\
\hline $32 \mathrm{D}$ & 10831 & Naturita Creek at Naturita & San Miguel & Hg.wf & Estimate & 16 & 16 & $<0.1$ & $<0.2$ & $<0.2$ & $<0.2$ \\
\hline 04D & 10780 & Silver Creek at Highway 145 & Upper Dolores & Hg.wu & Estimate & 22 & 22 & $<0.2$ & $<0.2$ & $<0.2$ & $<0.2$ \\
\hline $05 \mathrm{D}$ & 10716 & Dolores River below Rico & Upper Dolores & Hg.wu & Estimate & 17 & 17 & $<0.2$ & $<0.2$ & $<0.2$ & $<0.2$ \\
\hline $08 \mathrm{D}$ & $10901 \mathrm{~A}$ & Lost Canyon Creek near Dolores & Upper Dolores & Hg.wu & Estimate & 10 & 10 & $<0.2$ & $<0.2$ & $<0.2$ & $<0.2$ \\
\hline $25 \mathrm{D}$ & 10815 & San Miguel River at Society Turn & San Miguel & Hg.wu & Estimate & 19 & 19 & $<0.2$ & $<0.2$ & $<0.2$ & $<0.2$ \\
\hline $30 \mathrm{D}$ & 10860 & McKenzie Creek at mouth above confluence with San Miguel River & San Miguel & Hg.wu & Estimate & 14 & 14 & $<0.2$ & $<0.2$ & $<0.2$ & $<0.2$ \\
\hline $35 \mathrm{D}$ & 10903 & Salt Creek at Highway 141 & Lower Dolores & Hg.wu & Estimate & 10 & 10 & $<0.2$ & $<0.2$ & $<0.2$ & $<0.2$ \\
\hline $01 \mathrm{D}$ & 10784R & Coal Creek at FR 535 below Lizard Head Wilderness Area & Upper Dolores & Pb.wf & Estimate & 10 & 10 & $<1$ & $<1$ & $<1$ & $<1$ \\
\hline 02D & 10782 & Horse Creek at Highway 145 & Upper Dolores & Pb.wf & Estimate & 12 & 12 & $<0.1$ & $<1$ & $<1$ & $<1$ \\
\hline 03D & 10718 & Dolores River above Horse Creek & Upper Dolores & Pb.wf & Estimate & 16 & 14 & $<1$ & $<5$ & $<5$ & $<5$ \\
\hline 04D & 10780 & Silver Creek at Highway 145 & Upper Dolores & Pb.wf & ROS & 47 & 40 & $<1$ & 5.7 & 0.37 & 1 \\
\hline $05 \mathrm{D}$ & 10716 & Dolores River below Rico & Upper Dolores & Pb.wf & Estimate & 48 & 45 & $<0.1$ & $<5$ & $<5$ & $<5$ \\
\hline 07D & 10770 & West Dolores River near Stoner at Highway 145 & Upper Dolores & Pb.wf & Estimate & 20 & 20 & $<1$ & $<5$ & $<5$ & $<5$ \\
\hline $08 \mathrm{D}$ & $10901 \mathrm{~A}$ & Lost Canyon Creek near Dolores & Upper Dolores & Pb.wf & Estimate & 14 & 14 & $<1$ & $<1$ & $<1$ & $<1$ \\
\hline $11 \mathrm{D}$ & DRDOL12T & Dolores River at Dolores & Upper Dolores & Pb.wf & Estimate & 10 & 10 & $<0.5$ & $<30$ & $<30$ & $<30$ \\
\hline $13 \mathrm{D}$ & 10701 & Dolores River at Dolores above Mcphee Reservoir & Upper Dolores & Pb.wf & Estimate & 24 & 23 & $<1$ & 9 & $<1$ & $<1$ \\
\hline $20 \mathrm{D}$ & 10818 & San Miguel River above Marshall Creek & San Miguel & Pb.wf & Estimate & 11 & 11 & $<1$ & $<5$ & $<5$ & $<5$ \\
\hline $25 \mathrm{D}$ & 10815 & San Miguel River at Society Turn & San Miguel & Pb.wf & ROS & 75 & 64 & $<0.1$ & 12 & 0.37 & 1 \\
\hline $26 \mathrm{D}$ & 10871 & South Fork San Miguel River near mouth & San Miguel & Pb.wf & Estimate & 25 & 25 & $<1$ & $<5$ & $<5$ & $<5$ \\
\hline $27 \mathrm{D}$ & 10875 & Howard Fork San Miguel River at Ophir & San Miguel & Pb.wf & Estimate & 17 & 17 & $<1$ & $<5$ & $<5$ & $<5$ \\
\hline
\end{tabular}


Table 8. Summary of selected trace element concentrations at sites with 10 or more samples in the Dolores, Upper San Juan, and Lower San Juan River Basins, southwestern Colorado, 1990-2005.-Continued

[Site ID, site identification number shown on figure 1; Database ID, data repository identification number; <, less than; concentrations are given in micrograms per liter; K-M flipped, Kaplan-Meier method modified for left-censored data used to compute summary statistics; ROS, the robust "regression on order statistics" method used to compute summary statistics; Estimate, summary statistics were reported as less than the maximum reporting limit; N, number of samples; NC, number of samples with concentrations reported as less than the reporting limit; Min, minimum value; Max, maximum value; Med, median; $\mathrm{C}_{85}$, 85th percentile concentration; Al.wf, dissolved aluminum; Al.wu, total recoverable aluminum; Fe.wf, dissolved iron; Fe.wu, total recoverable iron; Hg.wf, dissolved mercury; Hg.wu, total recoverable mercury; Pb.wf, dissolved lead; Pb.wu, total recoverable lead; Se.wf, dissolved selenium; Se.wu, total recoverable selenium; Ur.wf, dissolved uranium; Zn.wf, dissolved zinc; Zn.wu, total recoverable zinc; WWTP, wastewater treatment plant; values shown in blue indicate that chronic State water-quality standards were not met and values shown in red indicate that acute and chronic State water-quality standards were not met]

\begin{tabular}{|c|c|c|c|c|c|c|c|c|c|c|c|}
\hline $\begin{array}{l}\text { Site } \\
\text { ID }\end{array}$ & $\begin{array}{c}\text { Database } \\
\text { ID }\end{array}$ & Site name & $\begin{array}{c}\text { Subbasin } \\
\text { name }\end{array}$ & $\begin{array}{c}\text { Con- } \\
\text { stituent }\end{array}$ & Method & $\mathbf{N}$ & NC & Min & Max & Med & $\mathbf{C}_{85}$ \\
\hline \multicolumn{12}{|c|}{ Dolores River Basin—Continued } \\
\hline 30D & 10860 & McKenzie Creek at mouth above confluence with San Miguel River & San Miguel & Pb.wf & Estimate & 17 & 17 & $<1$ & $<1$ & $<1$ & $<1$ \\
\hline $32 \mathrm{D}$ & 10831 & Naturita Creek at Naturita & San Miguel & Pb.wf & Estimate & 18 & 18 & $<1$ & $<5$ & $<5$ & $<5$ \\
\hline $35 \mathrm{D}$ & 10903 & Salt Creek at Highway 141 & Lower Dolores & Pb.wf & Estimate & 13 & 13 & $<1$ & $<40$ & $<40$ & $<40$ \\
\hline $36 \mathrm{D}$ & 10915 & West Creek in Unaweep Canyon & Lower Dolores & Pb.wf & Estimate & 14 & 14 & $<1$ & $<1$ & $<1$ & $<1$ \\
\hline $01 \mathrm{D}$ & $10784 \mathrm{R}$ & Coal Creek at FR 535 below Lizard Head Wilderness Area & Upper Dolores & Zn.wf & K-M flipped & 10 & 2 & $<10$ & 14 & 11 & 13 \\
\hline $02 \mathrm{D}$ & 10782 & Horse Creek at Highway 145 & Upper Dolores & Zn.wf & K-M flipped & 12 & 4 & $<10$ & $<100$ & 17 & 28 \\
\hline $03 \mathrm{D}$ & 10718 & Dolores River above Horse Creek & Upper Dolores & Zn.wf & ROS & 16 & 13 & $<8$ & 6,100 & 2.85 & 24 \\
\hline $04 \mathrm{D}$ & 10780 & Silver Creek at Highway 145 & Upper Dolores & Zn.wf & K-M flipped & 47 & 1 & $<1.8$ & 1,700 & 540 & 720 \\
\hline $05 \mathrm{D}$ & 10716 & Dolores River below Rico & Upper Dolores & Zn.wf & K-M flipped & 48 & 5 & $<10$ & 780 & 58 & 120 \\
\hline 07D & 10770 & West Dolores River near Stoner at Highway 145 & Upper Dolores & Zn.wf & ROS & 20 & 14 & $<8$ & 23 & 5.95 & 11 \\
\hline 08D & $10901 \mathrm{~A}$ & Lost Canyon Creek near Dolores & Upper Dolores & Zn.wf & ROS & 14 & 9 & $<10$ & $<100$ & 9.75 & 14 \\
\hline $11 \mathrm{D}$ & DRDOL12T & Dolores River at Dolores & Upper Dolores & Zn.wf & ROS & 10 & 5 & $<4$ & 157 & 3.18 & 21 \\
\hline $13 \mathrm{D}$ & 10701 & Dolores River at Dolores above Mcphee Reservoir & Upper Dolores & Zn.wf & ROS & 25 & 18 & $<10$ & 39 & 5.11 & 15 \\
\hline $20 \mathrm{D}$ & 10818 & San Miguel River above Marshall Creek & San Miguel & Zn.wf & K-M flipped & 11 & 0 & 55 & 480 & 250 & 430 \\
\hline $25 \mathrm{D}$ & 10815 & San Miguel River at Society Turn & San Miguel & Zn.wf & K-M flipped & 75 & 2 & $<8$ & 370 & 170 & 240 \\
\hline $26 \mathrm{D}$ & 10871 & South Fork San Miguel River near mouth & San Miguel & Zn.wf & K-M flipped & 25 & 3 & $<10$ & $<500$ & 35 & 61 \\
\hline $27 \mathrm{D}$ & 10875 & Howard Fork San Miguel River at Ophir & San Miguel & Zn.wf & K-M flipped & 17 & 0 & 16 & 130 & 89 & 120 \\
\hline $30 \mathrm{D}$ & 10860 & McKenzie Creek at mouth above confluence with San Miguel River & San Miguel & Zn.wf & K-M flipped & 17 & 4 & $<10$ & $<100$ & 20 & 27 \\
\hline $32 \mathrm{D}$ & 10831 & Naturita Creek at Naturita & San Miguel & Zn.wf & Estimate & 18 & 17 & $<8$ & $<16$ & $<16$ & $<16$ \\
\hline $35 \mathrm{D}$ & 10903 & Salt Creek at Highway 141 & Lower Dolores & Zn.wf & ROS & 13 & 10 & $<10$ & 1,600 & 583 & 1,300 \\
\hline $36 \mathrm{D}$ & 10915 & West Creek in Unaweep Canyon & Lower Dolores & Zn.wf & Estimate & 14 & 14 & $<8$ & $<10$ & $<10$ & $<10$ \\
\hline $11 \mathrm{D}$ & DRDOL12T & Dolores River at Dolores & Upper Dolores & Zn.wu & K-M flipped & 10 & 2 & $<4$ & 25 & 13.5 & 21 \\
\hline $01 \mathrm{D}$ & $10784 \mathrm{R}$ & Coal Creek at FR 535 below Lizard Head Wilderness Area & Upper Dolores & Se.wf & Estimate & 10 & 10 & $<1$ & $<1$ & $<1$ & $<1$ \\
\hline $02 \mathrm{D}$ & 10782 & Horse Creek at Highway 145 & Upper Dolores & Se.wf & Estimate & 12 & 12 & $<0.4$ & $<1$ & $<1$ & $<1$ \\
\hline $04 \mathrm{D}$ & 10780 & Silver Creek at Highway 145 & Upper Dolores & Se.wf & Estimate & 36 & 33 & $<0.4$ & $<1$ & $<1$ & $<1$ \\
\hline $05 \mathrm{D}$ & 10716 & Dolores River below Rico & Upper Dolores & Se.wf & Estimate & 35 & 33 & $<0.4$ & $<1$ & $<1$ & $<1$ \\
\hline $08 \mathrm{D}$ & $10901 \mathrm{~A}$ & Lost Canyon Creek near Dolores & Upper Dolores & Se.wf & Estimate & 14 & 14 & $<1$ & $<1$ & $<1$ & $<1$ \\
\hline $11 \mathrm{D}$ & DRDOL12T & Dolores River at Dolores & Upper Dolores & Se.wf & Estimate & 10 & 9 & $<1$ & 62.1 & $<40$ & $<40$ \\
\hline $13 \mathrm{D}$ & 10701 & Dolores River at Dolores above Mcphee Reservoir & Upper Dolores & Se.wf & Estimate & 25 & 25 & $<1$ & $<1$ & $<1$ & $<1$ \\
\hline $15 \mathrm{D}$ & 000085 & Dolores River above confluence with San Miguel River & Upper Dolores & Se.wf & ROS & 11 & 6 & $<1$ & 8.9 & 0.66 & 3 \\
\hline $25 \mathrm{D}$ & 10815 & San Miguel River at Society Turn & San Miguel & Se.wf & Estimate & 45 & 39 & $<1$ & 3.1 & $<1$ & $<1$ \\
\hline $26 \mathrm{D}$ & 10871 & South Fork San Miguel River near mouth & San Miguel & Se.wf & Estimate & 17 & 15 & $<1$ & $<1$ & $<1$ & $<1$ \\
\hline $27 \mathrm{D}$ & 10875 & Howard Fork San Miguel River at Ophir & San Miguel & Se.wf & Estimate & 10 & 10 & $<1$ & $<1$ & $<1$ & $<1$ \\
\hline $29 \mathrm{D}$ & 000101 & San Miguel River near Norwood & San Miguel & Se.wf & Estimate & 25 & 24 & $<1$ & $<10$ & $<10$ & $<10$ \\
\hline
\end{tabular}


Table 8. Summary of selected trace element concentrations at sites with 10 or more samples in the Dolores, Upper San Juan, and Lower San Juan River Basins, southwestern Colorado, 1990-2005.-Continued

[Site ID, site identification number shown on figure 1; Database ID, data repository identification number; <, less than; concentrations are given in micrograms per liter; K-M flipped, Kaplan-Meier method modified for left-censored data used to compute summary statistics; ROS, the robust "regression on order statistics" method used to compute summary statistics; Estimate, summary statistics were reported as less than the maximum reporting limit; N, number of samples; NC, number of samples with concentrations reported as less than the reporting limit; Min, minimum value; Max, maximum value; Med, median; $\mathrm{C}_{85}, 85$ th percentile concentration; Al.wf, dissolved aluminum; Al.wu, total recoverable aluminum; Fe.wf, dissolved iron; Fe.wu, total recoverable iron; Hg.wf, dissolved mercury; Hg.wu, total recoverable mercury; Pb.wf, dissolved lead; Pb.wu, total recoverable lead; Se.wf, dissolved selenium; Se.wu, total recoverable selenium; Ur.wf, dissolved uranium; Zn.wf, dissolved zinc; Zn.wu, total recoverable zinc; WWTP, wastewater treatment plant; values shown in blue indicate that chronic State water-quality standards were not met and values shown in red indicate that acute and chronic State water-quality standards were not met]

\begin{tabular}{|c|c|c|c|c|c|c|c|c|c|c|c|}
\hline $\begin{array}{l}\text { Site } \\
\text { ID }\end{array}$ & $\begin{array}{l}\text { Database } \\
\text { ID }\end{array}$ & Site name & $\begin{array}{l}\text { Subbasin } \\
\text { name }\end{array}$ & $\begin{array}{c}\text { Con- } \\
\text { stituent }\end{array}$ & Method & $\mathbf{N}$ & NC & Min & Max & Med & $C_{85}$ \\
\hline \multicolumn{12}{|c|}{ Dolores River Basin-Continued } \\
\hline $30 \mathrm{D}$ & 10860 & McKenzie Creek at mouth above confluence with San Miguel River & San Miguel & Se.wf & K-M flipped & 17 & 6 & $<1$ & 2 & 1 & 2 \\
\hline $32 \mathrm{D}$ & 10831 & Naturita Creek at Naturita & San Miguel & Se.wf & K-M flipped & 11 & 4 & $<1$ & 2.6 & 1 & 1.8 \\
\hline 34D & 000084 & San Miguel River at confluence with Dolores River & San Miguel & Se.wf & ROS & 34 & 18 & $<1$ & $<10$ & 0.68 & 1.2 \\
\hline $35 \mathrm{D}$ & 10903 & Salt Creek at Highway 141 & Lower Dolores & Se.wf & ROS & 13 & 8 & $<1$ & $<25$ & 20 & 23 \\
\hline $13 \mathrm{D}$ & 10701 & Dolores River at Dolores above Mcphee Reservoir & Upper Dolores & Ur.wf & Estimate & 10 & 9 & $<1$ & $<3$ & $<3$ & $<3$ \\
\hline $15 \mathrm{D}$ & 000085 & Dolores River above confluence with San Miguel River & Upper Dolores & Ur.wf & K-M flipped & 12 & 5 & 3 & 8 & 3 & 4 \\
\hline $34 \mathrm{D}$ & 000084 & San Miguel River at confluence with Dolores River & San Miguel & Ur.wf & K-M flipped & 21 & 3 & 1 & 12 & 3.6 & 6 \\
\hline \multicolumn{12}{|c|}{ Upper San Juan River Basin } \\
\hline $02 \mathrm{~A}$ & A33 & Animas River at Eureka & Animas & Al.wf & K-M flipped & 18 & 7 & $<40$ & 200 & 55 & 95 \\
\hline $03 \mathrm{~A}$ & A39 & Eureka below Ben Franklin & Animas & Al.wf & K-M flipped & 23 & 7 & $<10$ & 200 & 100 & 200 \\
\hline 04A & A53 & Animas River at Howardsville & Animas & Al.wf & ROS & 14 & 8 & $<40$ & 113 & 49 & 84 \\
\hline 07A & A68 & Animas River at Silverton & Animas & Al.wf & K-M flipped & 133 & 52 & $<0.062$ & $<230$ & 50 & 89 \\
\hline 09A & $\mathrm{CC} 18$ & $\begin{array}{l}\text { North Fork Cement Creek upstream from Gold King mine, } \\
\text { \#7 level (AMLI mine \# 103) }\end{array}$ & Animas & Al.wf & K-M flipped & 96 & 0 & 100 & 44,200 & 3,490 & 5,390 \\
\hline $10 \mathrm{~A}$ & $\mathrm{CC} 32$ & South Fork Cement Creek downstream from Velocity Lake & Animas & Al.wf & K-M flipped & 11 & 5 & $<40$ & 125 & 48 & 123 \\
\hline $11 \mathrm{~A}$ & $\mathrm{CC} 31$ & $\begin{array}{l}\text { South Fork Cement Creek downstream from Big Colorado mine } \\
\quad \text { (AMLI mine \# 150) }\end{array}$ & Animas & Al.wf & K-M flipped & 14 & 0 & 88 & 7,850 & 4,262 & 6,564 \\
\hline $12 \mathrm{~A}$ & $\mathrm{CC} 23$ & Prospect Gulch upstream from Red Spring & Animas & Al.wf & K-M flipped & 15 & 0 & 57 & 1,310 & 57 & 830 \\
\hline $14 \mathrm{~A}$ & $\mathrm{CC} 14$ & Minnesota Gulch near mouth & Animas & Al.wf & K-M flipped & 13 & 0 & 45 & 2,877 & 1,039 & 2,300 \\
\hline $15 \mathrm{~A}$ & $\mathrm{CC} 20$ & Porcupine Gulch upstream from mines & Animas & Al.wf & K-M flipped & 123 & 8 & $<40$ & 11,500 & 500 & 2,400 \\
\hline $16 \mathrm{~A}$ & $\mathrm{CC} 17$ & Niagara Gulch near mouth & Animas & Al.wf & K-M flipped & 32 & 0 & 55 & 3,200 & 1,000 & 1,859 \\
\hline $19 \mathrm{~A}$ & CEM48 & Cement Creek at USGS gaging station & Animas & Al.wf & K-M flipped & 12 & 0 & 13 & 4,500 & 2,550 & 4,400 \\
\hline $20 \mathrm{~A}$ & M02 & Mineral Creek near headwaters & Animas & Al.wf & K-M flipped & 16 & 0 & 3,900 & 85,000 & 43,150 & 67,000 \\
\hline $21 \mathrm{~A}$ & M02A & $\begin{array}{l}\text { Highway } 550 \text { drainage ditch above M01 confluence-east side } \\
\text { of Highway } 550\end{array}$ & Animas & Al.wf & K-M flipped & 14 & 0 & 3,280 & 63,700 & 24,600 & 57,700 \\
\hline $22 \mathrm{~A}$ & M07 & Mineral Creek at Chattanooga & Animas & Al.wf & K-M flipped & 16 & 2 & $<40$ & 2,700 & 243 & 1,800 \\
\hline $23 \mathrm{~A}$ & M13 & Mineral Creek just below confluence with Browns Gulch & Animas & Al.wf & ROS & 13 & 8 & $<40$ & 180 & 36 & 90 \\
\hline $30 \mathrm{~A}$ & M27 & Mineral Creek above confluence with South Fork Mineral Creek & Animas & Al.wf & K-M flipped & 12 & 0 & 52 & 11,700 & 749 & 6,310 \\
\hline $32 \mathrm{~A}$ & M34 & Mineral Creek at Silverton & Animas & Al.wf & K-M flipped & 143 & 34 & $<1$ & 5,230 & 88 & 2,360 \\
\hline $33 \mathrm{~A}$ & 09359020 & Animas River below Silverton & Animas & Al.wf & K-M flipped & 43 & 0 & 10 & 370 & 31 & 107 \\
\hline $35 \mathrm{~A}$ & A72 & Animas River downstream from Silverton & Animas & Al.wf & K-M flipped & 169 & 49 & $<1$ & 1,900 & 77 & 634 \\
\hline $39 \mathrm{~A}$ & 9445 & Cascade Creek at Highway 550 & Animas & Al.wf & Estimate & 16 & 14 & $<50$ & $<50$ & $<50$ & $<50$ \\
\hline $43 \mathrm{~A}$ & 9440 & Falls Creek at 0.65 Road & Animas & Al.wf & Estimate & 13 & 11 & $<50$ & $<250$ & $<250$ & $<250$ \\
\hline $46 \mathrm{~A}$ & 9420 & Animas River at Durango & Animas & Al.wf & ROS & 30 & 24 & $<30$ & $<250$ & 28 & 54 \\
\hline
\end{tabular}


Table 8. Summary of selected trace element concentrations at sites with 10 or more samples in the Dolores, Upper San Juan, and Lower San Juan River Basins, southwestern Colorado, 1990-2005.-Continued

[Site ID, site identification number shown on figure 1; Database ID, data repository identification number; <, less than; concentrations are given in micrograms per liter; K-M flipped, Kaplan-Meier method modified for left-censored data used to compute summary statistics; ROS, the robust "regression on order statistics" method used to compute summary statistics; Estimate, summary statistics were reported as less than the maximum reporting limit; N, number of samples; NC, number of samples with concentrations reported as less than the reporting limit; Min, minimum value; Max, maximum value; Med, median; $\mathrm{C}_{85}$, 85th percentile concentration; Al.wf, dissolved aluminum; Al.wu, total recoverable aluminum; Fe.wf, dissolved iron; Fe.wu, total recoverable iron; Hg.wf, dissolved mercury; Hg.wu, total recoverable mercury; Pb.wf, dissolved lead; Pb.wu, total recoverable lead; Se.wf, dissolved selenium; Se.wu, total recoverable selenium; Ur.wf, dissolved uranium; Zn.wf, dissolved zinc; Zn.wu, total recoverable zinc; WWTP, wastewater treatment plant; values shown in blue indicate that chronic State water-quality standards were not met and values shown in red indicate that acute and chronic State water-quality standards were not met]

\begin{tabular}{|c|c|c|c|c|c|c|c|c|c|c|c|}
\hline $\begin{array}{l}\text { Site } \\
\text { ID }\end{array}$ & $\begin{array}{c}\text { Database } \\
\text { ID }\end{array}$ & Site name & $\begin{array}{c}\text { Subbasin } \\
\text { name }\end{array}$ & $\begin{array}{c}\text { Con- } \\
\text { stituent }\end{array}$ & Method & $\mathbf{N}$ & NC & Min & Max & Med & $\mathbf{C}_{85}$ \\
\hline \multicolumn{12}{|c|}{ Upper San Juan River Basin-Continued } \\
\hline $48 \mathrm{~A}$ & DRALP001 & DRALP001 & Animas & Al.wf & K-M flipped & 21 & 3 & $<1$ & 86 & 18.5 & 29 \\
\hline $49 \mathrm{~A}$ & DRALP002 & Animas River at Durango & Animas & Al.wf & K-M flipped & 31 & 5 & $<1$ & 166 & 22 & 58 \\
\hline $50 \mathrm{~A}$ & DRALP209 & Animas River behind BMX track at Durango & Animas & Al.wf & K-M flipped & 21 & 0 & 7.3 & 128 & 34 & 68 \\
\hline $54 \mathrm{~A}$ & 9415 & Salt Creek at 309A Road & Animas & Al.wf & K-M flipped & 15 & 7 & $<50$ & $<250$ & 76 & 100 \\
\hline $01 \mathrm{U}$ & 9850 & Little Navajo River at Highway 84 & Upper San Juan & Al.wf & Estimate & 16 & 14 & $<50$ & $<500$ & $<500$ & $<500$ \\
\hline $03 \mathrm{U}$ & 9860 & Rio Blanco at Highway 84 & Upper San Juan & Al.wf & ROS & 17 & 12 & $<50$ & 400 & 38 & 120 \\
\hline $05 \mathrm{U}$ & 9165 & Sand Creek at mouth above East Fork San Juan River & Upper San Juan & Al.wf & ROS & 12 & 8 & $<50$ & 110 & 62 & 93 \\
\hline $10 \mathrm{U}$ & 9120 & McCabe Creek above Pagosa Springs & Upper San Juan & Al.wf & Estimate & 17 & 16 & $<50$ & $<500$ & $<500$ & $<500$ \\
\hline $15 \mathrm{U}$ & 9290 & East Fork Piedra River below Piedra Falls & Piedra & Al.wf & Estimate & 12 & 11 & $<50$ & $<50$ & $<50$ & $<50$ \\
\hline $16 \mathrm{U}$ & 9250 & Piedra River at Highway 160 & Piedra & Al.wf & ROS & 53 & 40 & $<30$ & $<250$ & 23 & 68 \\
\hline $17 \mathrm{U}$ & 9245 & Stollsteimer Creek at Highway 151 & Piedra & Al.wf & Estimate & 18 & 17 & $<50$ & $<500$ & $<500$ & $<500$ \\
\hline $20 \mathrm{U}$ & 09352800 & Los Pinos River above Vallecito Reservoir near Bayfield & Upper San Juan & Al.wf & K-M flipped & 14 & 5 & $<7.5$ & 34 & 4.66 & 27 \\
\hline $21 \mathrm{U}$ & 9380 & Los Pinos River above Vallecito Reservoir & Upper San Juan & Al.wf & ROS & 52 & 46 & $<30$ & 110 & 28 & 52 \\
\hline $22 \mathrm{U}$ & 09352900 & Vallecito Creek near Bayfield & Upper San Juan & Al.wf & K-M flipped & 44 & 2 & $<10$ & 80 & 40 & 70 \\
\hline $23 \mathrm{U}$ & 9370 & Vallecito Creek near mouth & Upper San Juan & Al.wf & ROS & 51 & 34 & $<30$ & 170 & 38 & 75 \\
\hline $24 \mathrm{U}$ & 372236107344400 & Los Pinos River below Vallecito Reservoir near Bayfield & Upper San Juan & Al.wf & K-M flipped & 16 & 4 & $<10$ & 51 & 19 & 32 \\
\hline $25 \mathrm{U}$ & 9355 & Wallace Gulch at 502 Road north of Bayfield & Upper San Juan & Al.wf & Estimate & 16 & 15 & $<50$ & $<250$ & $<250$ & $<250$ \\
\hline $30 \mathrm{U}$ & 9680 & La Plata at Hesperus & Middle San Juan & Al.wf & ROS & 43 & 38 & $<11$ & 82 & 15 & 33 \\
\hline $31 \mathrm{U}$ & 9610 & Spring Creek near Breen & Middle San Juan & Al.wf & Estimate & 12 & 12 & $<50$ & $<250$ & $<250$ & $<250$ \\
\hline $32 \mathrm{U}$ & 9720 & East Fork Mancos River at 44 Road & Mancos & Al.wf & ROS & 22 & 15 & $<30$ & 160 & 41 & 100 \\
\hline $34 \mathrm{U}$ & 9715 & Chicken Creek at Mancos & Mancos & Al.wf & ROS & 18 & 13 & $<50$ & $<500$ & 19 & 120 \\
\hline $02 \mathrm{~A}$ & A33 & Animas River at Eureka & Animas & Al.wu & K-M flipr & 12 & 0 & 210 & 472 & 332 & 429 \\
\hline $07 \mathrm{~A}$ & A68 & Animas River at Silverton & Animas & Al.wu & K-M flipped & 94 & 14 & $<20$ & 600 & 130 & 300 \\
\hline $10 \mathrm{~A}$ & $\mathrm{CC} 32$ & South Fork Cement Creek downstream from Velocity Lake & Animas & Al.wu & ROS & 10 & 5 & $<40$ & 249 & 57 & 241 \\
\hline $12 \mathrm{~A}$ & $\mathrm{CC} 23$ & Prospect Gulch upstream from Red Spring & Animas & Al.wu & K-M flipped & 14 & 0 & 285 & 1,279 & 285 & 790 \\
\hline $32 \mathrm{~A}$ & M34 & Mineral Creek at Silverton & Animas & Al.wu & K-M flipped & 108 & 0 & 1.58 & 7,000 & 2,000 & 4,500 \\
\hline $33 \mathrm{~A}$ & 09359020 & Animas River below Silverton & Animas & Al.wu & K-M flipped & 36 & 0 & 428 & 2,792 & 1,281 & 2,213 \\
\hline $35 \mathrm{~A}$ & A72 & Animas River downstream from Silverton & Animas & Al.wu & K-M flipped & 66 & 0 & 1.31 & 3,707 & 1,242 & 2,322 \\
\hline $48 \mathrm{~A}$ & DRALP001 & DRALP001 & Animas & Al.wu & K-M flipped & 21 & 1 & $<1$ & 1,056 & 144 & 420 \\
\hline $49 \mathrm{~A}$ & DRALP002 & Animas River at Durango & Animas & Al.wu & K-M flipped & 31 & 1 & $<1$ & 1,528 & 164 & 606 \\
\hline $50 \mathrm{~A}$ & DRALP209 & Animas River behind BMX track at Durango & Animas & Al.wu & K-M flipped & 21 & 0 & 30 & 880 & 185 & 463 \\
\hline $02 \mathrm{~A}$ & A33 & Animas River at Eureka & Animas & Fe.wf & Estimate & 13 & 11 & $<30$ & $<30$ & $<30$ & $<30$ \\
\hline $03 \mathrm{~A}$ & A39 & Eureka below Ben Franklin & Animas & Fe.wf & ROS & 21 & 13 & $<50$ & 150 & 31 & 60 \\
\hline
\end{tabular}


Table 8. Summary of selected trace element concentrations at sites with 10 or more samples in the Dolores, Upper San Juan, and Lower San Juan River Basins, southwestern Colorado, 1990-2005.-Continued

[Site ID, site identification number shown on figure 1; Database ID, data repository identification number; <, less than; concentrations are given in micrograms per liter; K-M flipped, Kaplan-Meier method modified for left-censored data used to compute summary statistics; ROS, the robust "regression on order statistics" method used to compute summary statistics; Estimate, summary statistics were reported as less than the maximum reporting limit; N, number of samples; NC, number of samples with concentrations reported as less than the reporting limit; Min, minimum value; Max, maximum value; Med, median; $\mathrm{C}_{35}$ 85th percentile concentration; Al.wf, dissolved aluminum; Al.wu, total recoverable aluminum; Fe.wf, dissolved iron; Fe.wu, total recoverable iron; Hg.wf, dissolved mercury; Hg.wu, total recoverable mercury; Pb.wf, dissolved lead; Pb.wu, total recoverable lead; Se.wf, dissolved selenium; Se.wu, total recoverable selenium; Ur.wf, dissolved uranium; Zn.wf, dissolved zinc; Zn.wu, total recoverable zinc; WWTP, wastewater treatment plant; values shown in blue indicate that chronic State water-quality standards were not met and values shown in red indicate that acute and chronic State water-quality standards were not met]

\begin{tabular}{|c|c|c|c|c|c|c|c|c|c|c|c|}
\hline $\begin{array}{l}\text { Site } \\
\text { ID }\end{array}$ & $\begin{array}{l}\text { Database } \\
\text { ID }\end{array}$ & Site name & $\begin{array}{c}\text { Subbasin } \\
\text { name }\end{array}$ & $\begin{array}{c}\text { Con- } \\
\text { stituent }\end{array}$ & Method & $\mathbf{N}$ & NC & Min & Max & Med & $\mathrm{C}_{85}$ \\
\hline \multicolumn{12}{|c|}{ Upper San Juan River Basin-Continued } \\
\hline 04A & A53 & Animas River at Howardsville & Animas & Fe.wf & K-M flipped & 16 & 6 & $<30$ & 171 & 40 & 57 \\
\hline $05 \mathrm{~A}$ & A60 & Animas River downstream from Arrastra Gulch & Animas & Fe.wf & ROS & 10 & 7 & $<30$ & 69 & 14 & 31 \\
\hline 07A & A68 & Animas River at Silverton & Animas & Fe.wf & K-M flipped & 153 & 29 & $<10$ & $<500$ & 38 & 90 \\
\hline $09 \mathrm{~A}$ & CC18 & $\begin{array}{l}\text { North Fork Cement Creek upstream from Gold King mine, } \\
\text { \#7 level (AMLI mine \# 103) }\end{array}$ & Animas & Fe.wf & K-M flipped & 95 & 1 & $<30$ & 27,500 & 1,000 & 6,590 \\
\hline $10 \mathrm{~A}$ & $\mathrm{CC} 32$ & South Fork Cement Creek downstream from Velocity Lake & Animas & Fe.wf & K-M flipped & 15 & 1 & $<30$ & 3,634 & 3,452 & 3,585 \\
\hline $11 \mathrm{~A}$ & $\mathrm{CC} 31$ & $\begin{array}{l}\text { South Fork Cement Creek downstream from Big Colorado mine } \\
\text { (AMLI mine \# 150) }\end{array}$ & Animas & Fe.wf & K-M flipped & 13 & 0 & 3,068 & 20,896 & 6,796 & 17,452 \\
\hline $12 \mathrm{~A}$ & $\mathrm{CC} 23$ & Prospect Gulch upstream from Red Spring & Animas & Fe.wf & K-M flipped & 14 & 0 & 83 & 4,400 & 147 & 456 \\
\hline $14 \mathrm{~A}$ & $\mathrm{CC} 14$ & Minnesota Gulch near mouth & Animas & Fe.wf & K-M flipped & 11 & 1 & $<30$ & 22,970 & 12,719 & 14,000 \\
\hline $15 \mathrm{~A}$ & $\mathrm{CC} 20$ & Porcupine Gulch upstream from mines & Animas & Fe.wf & K-M flipped & 120 & 56 & $<20$ & 34,200 & 40 & 2,100 \\
\hline $16 \mathrm{~A}$ & $\mathrm{CC} 17$ & Niagara Gulch near mouth & Animas & Fe.wf & K-M flipped & 31 & 0 & 702 & 4,850 & 2,460 & 3,620 \\
\hline $20 \mathrm{~A}$ & M02 & Mineral Creek near headwaters & Animas & Fe.wf & K-M flipped & 14 & 0 & 42,200 & 683,000 & 309,500 & 454,000 \\
\hline $21 \mathrm{~A}$ & M02A & $\begin{array}{l}\text { Highway } 550 \text { drainage ditch above M01 confluence-east side of } \\
\text { Highway } 550\end{array}$ & Animas & Fe.wf & K-M flipped & 14 & 0 & 23,500 & 543,000 & 207,500 & 354,000 \\
\hline $22 \mathrm{~A}$ & M07 & Mineral Creek at Chattanooga & Animas & Fe.wf & K-M flipped & 15 & 0 & 33 & 12,000 & 660 & 2,200 \\
\hline $23 \mathrm{~A}$ & M13 & Mineral Creek just below confluence with Browns Gulch & Animas & Fe.wf & K-M flipped & 13 & 3 & $<30$ & 262 & 47 & 210 \\
\hline $30 \mathrm{~A}$ & M27 & Mineral Creek above confluence with South Fork Mineral Creek & Animas & Fe.wf & K-M flipped & 11 & 0 & 430 & 7,600 & 2,670 & 4,690 \\
\hline $32 \mathrm{~A}$ & M34 & Mineral Creek at Silverton & Animas & Fe.wf & K-M flipped & 162 & 2 & $<30$ & 6,230 & 1,855 & 3,400 \\
\hline $33 \mathrm{~A}$ & 09359020 & Animas River below Silverton & Animas & Fe.wf & K-M flipped & 39 & 0 & 55 & 2,960 & 870 & 2,236 \\
\hline $35 \mathrm{~A}$ & A72 & Animas River downstream from Silverton & Animas & Fe.wf & K-M flipped & 183 & 3 & $<30$ & 4,600 & 950 & 2,600 \\
\hline $37 \mathrm{~A}$ & 374248107323601 & Big Eldorado inflow & Animas & Fe.wf & K-M flipped & 15 & 4 & $<3$ & 36 & 6 & 11 \\
\hline $38 \mathrm{~A}$ & 374248107324501 & Little Eldorado inflow & Animas & Fe.wf & K-M flipped & 14 & 1 & $<3$ & 13 & 6 & 9 \\
\hline $39 \mathrm{~A}$ & 9445 & Cascade Creek at Highway 550 & Animas & Fe.wf & ROS & 16 & 12 & $<10$ & 28 & 6.31 & 16 \\
\hline $41 \mathrm{~A}$ & DRALP003 & Animas at Durango Mall & Animas & Fe.wf & ROS & 62 & 44 & $<50$ & 198 & 31 & 62 \\
\hline $43 \mathrm{~A}$ & 9440 & Falls Creek at 0.65 Road & Animas & Fe.wf & ROS & 13 & 9 & $<10$ & 75 & 2.98 & 23 \\
\hline $46 \mathrm{~A}$ & 9420 & Animas River at Durango & Animas & Fe.wf & K-M flipped & 30 & 6 & $<10$ & 110 & 17 & 59 \\
\hline $47 \mathrm{~A}$ & DRALPLC2 & Lightner Creek at mouth at Durango & Animas & Fe.wf & ROS & 41 & 32 & $<50$ & 404 & 25 & 84 \\
\hline $48 \mathrm{~A}$ & DRALP001 & DRALP001 & Animas & Fe.wf & ROS & 64 & 52 & $<50$ & 255 & 20 & 61 \\
\hline $49 \mathrm{~A}$ & DRALP002 & Animas River at Durango & Animas & Fe.wf & ROS & 87 & 65 & $<30$ & 339 & 27 & 68 \\
\hline $54 \mathrm{~A}$ & 9415 & Salt Creek at 309A Road & Animas & Fe.wf & K-M flipped & 15 & 1 & $<50$ & 120 & 61 & 93 \\
\hline $01 \mathrm{U}$ & 9850 & Little Navajo River at Highway 84 & Upper San Juan & Fe.wf & K-M flipped & 16 & 1 & $<10$ & 130 & 50 & 120 \\
\hline $03 \mathrm{U}$ & 9860 & Rio Blanco at Highway 84 & Upper San Juan & Fe.wf & K-M flipped & 17 & 3 & $<10$ & 200 & 30 & 100 \\
\hline $05 \mathrm{U}$ & 9165 & Sand Creek at mouth above East Fork San Juan River & Upper San Juan & Fe.wf & K-M flipped & 12 & 5 & $<10$ & 87 & 16 & 52 \\
\hline
\end{tabular}


Table 8. Summary of selected trace element concentrations at sites with 10 or more samples in the Dolores, Upper San Juan, and Lower San Juan River Basins, southwestern Colorado, 1990-2005.-Continued

[Site ID, site identification number shown on figure 1; Database ID, data repository identification number; <, less than; concentrations are given in micrograms per liter; K-M flipped, Kaplan-Meier method modified for left-censored data used to compute summary statistics; ROS, the robust "regression on order statistics" method used to compute summary statistics; Estimate, summary statistics were reported as less than the maximum reporting limit; N, number of samples; NC, number of samples with concentrations reported as less than the reporting limit; Min, minimum value; Max, maximum value; Med, median; $\mathrm{C}_{85}$, 85th percentile concentration; Al.wf, dissolved aluminum; Al.wu, total recoverable aluminum; Fe.wf, dissolved iron; Fe.wu, total recoverable iron; Hg.wf, dissolved mercury; Hg.wu, total recoverable mercury; Pb.wf, dissolved lead; Pb.wu, total recoverable lead; Se.wf, dissolved selenium; Se.wu, total recoverable selenium; Ur.wf, dissolved uranium; Zn.wf, dissolved zinc; Zn.wu, total recoverable zinc; WWTP, wastewater treatment plant; values shown in blue indicate that chronic State water-quality standards were not met and values shown in red indicate that acute and chronic State water-quality standards were not met]

\begin{tabular}{|c|c|c|c|c|c|c|c|c|c|c|c|}
\hline $\begin{array}{c}\text { Site } \\
\text { ID }\end{array}$ & $\begin{array}{c}\text { Database } \\
\text { ID }\end{array}$ & Site name & $\begin{array}{c}\text { Subbasin } \\
\text { name }\end{array}$ & $\begin{array}{c}\text { Con- } \\
\text { stituent }\end{array}$ & Method & $\mathbf{N}$ & NC & Min & Max & Med & $C_{85}$ \\
\hline \multicolumn{12}{|c|}{ Upper San Juan River Basin—Continued } \\
\hline $10 \mathrm{U}$ & 9120 & McCabe Creek above Pagosa Springs & Upper San Juan & Fe.wf & K-M flipped & 17 & 4 & $<10$ & 60 & 36 & 56 \\
\hline $15 \mathrm{U}$ & 9290 & East Fork Piedra River below Piedra Falls & Piedra & Fe.wf & K-M flipped & 12 & 3 & $<10$ & 30 & 12.5 & 30 \\
\hline $16 \mathrm{U}$ & 9250 & Piedra River at Highway 160 & Piedra & Fe.wf & K-M flipped & 45 & 2 & $<10$ & 200 & 42 & 100 \\
\hline $17 \mathrm{U}$ & 9245 & Stollsteimer Creek at Highway 151 & Piedra & Fe.wf & ROS & 18 & 12 & $<10$ & 73 & 10.1 & 30 \\
\hline $20 \mathrm{U}$ & 09352800 & Los Pinos River above Vallecito Reservoir near Bayfield & Upper San Juan & Fe.wf & K-M flipped & 12 & 1 & $<13$ & 39 & 19.75 & 25 \\
\hline $21 \mathrm{U}$ & 9380 & Los Pinos River above Vallecito Reservoir & Upper San Juan & Fe.wf & K-M flipped & 46 & 7 & $<10$ & 73 & 19.5 & 45 \\
\hline $22 \mathrm{U}$ & 09352900 & Vallecito Creek near Bayfield & Upper San Juan & Fe.wf & K-M flipped & 45 & 16 & $<3$ & 51 & 9 & 23 \\
\hline $23 \mathrm{U}$ & 9370 & Vallecito Creek near mouth & Upper San Juan & Fe.wf & ROS & 44 & 30 & $<10$ & 170 & 6.78 & 20 \\
\hline $24 \mathrm{U}$ & 372236107344400 & Los Pinos River below Vallecito Reservoir near Bayfield & Upper San Juan & Fe.wf & K-M flipped & 16 & 3 & $<4.4$ & 17 & 8.35 & 15 \\
\hline $25 \mathrm{U}$ & 9355 & Wallace Gulch at 502 Road north of Bayfield & Upper San Juan & Fe.wf & K-M flipped & 16 & 2 & $<50$ & 160 & 32 & 100 \\
\hline $30 \mathrm{U}$ & 9680 & La Plata at Hesperus & Middle San Juan & Fe.wf & K-M flipped & 14 & 4 & $<10$ & 50,000 & 12 & 24 \\
\hline $31 \mathrm{U}$ & 9610 & Spring Creek near Breen & Middle San Juan & Fe.wf & K-M flipped & 12 & 1 & $<50$ & 130 & 54 & 110 \\
\hline $32 \mathrm{U}$ & 9720 & East Fork Mancos River at 44 Road & Mancos & Fe.wf & K-M flipped & 11 & 3 & $<10$ & 110 & 27 & 46 \\
\hline $34 \mathrm{U}$ & 9715 & Chicken Creek at Mancos & Mancos & Fe.wf & K-M flipped & 17 & 2 & $<100$ & 250 & 47 & 76 \\
\hline $02 \mathrm{~A}$ & A33 & Animas River at Eureka & Animas & Fe.wu & K-M flipped & 13 & 0 & 46 & 179 & 69 & 166 \\
\hline $06 \mathrm{~A}$ & AN68 & Animas River at USGS gaging station above 14th Street & Animas & Fe.wu & K-M flipped & 11 & 0 & 43 & 710 & 99 & 430 \\
\hline $07 \mathrm{~A}$ & A68 & Animas River at Silverton & Animas & Fe.wu & K-M flipped & 107 & 2 & $<50$ & 2,810 & 200 & 470 \\
\hline $10 \mathrm{~A}$ & $\mathrm{CC} 32$ & South Fork Cement Creek downstream from Velocity Lake & Animas & Fe.wu & K-M flipped & 13 & 0 & 3,438 & 15,435 & 3,888 & 8,955 \\
\hline $12 \mathrm{~A}$ & $\mathrm{CC} 23$ & Prospect Gulch upstream from Red Spring & Animas & Fe.wu & K-M flipped & 14 & 0 & 286 & 5,700 & 286 & 740 \\
\hline $15 \mathrm{~A}$ & $\mathrm{CC} 20$ & Porcupine Gulch upstream from mines & Animas & Fe.wu & K-M flipped & 12 & 0 & 320 & 34,400 & 2,485 & 34,300 \\
\hline $19 \mathrm{~A}$ & CEM48 & Cement Creek at USGS gaging station & Animas & Fe.wu & K-M flipped & 12 & 0 & 4,200 & 8,600 & 6,100 & 8,100 \\
\hline $20 \mathrm{~A}$ & M02 & Mineral Creek near headwaters & Animas & Fe.wu & K-M flipped & 10 & 0 & 52,000 & 910,000 & 225,000 & 580,000 \\
\hline $30 \mathrm{~A}$ & M27 & Mineral Creek above confluence with South Fork Mineral Creek & Animas & Fe.wu & K-M flipped & 11 & 0 & 900 & 9,500 & 3,387 & 6,412 \\
\hline $32 \mathrm{~A}$ & M34 & Mineral Creek at Silverton & Animas & Fe.wu & K-M flipped & 114 & 0 & 190 & 12,100 & 3,361 & 5,800 \\
\hline $33 \mathrm{~A}$ & 09359020 & Animas River below Silverton & Animas & Fe.wu & K-M flipped & 43 & 0 & 669 & 6,600 & 2,892 & 4,400 \\
\hline $34 \mathrm{~A}$ & AN72 & Animas River at USGS gaging station just above railroad bridge & Animas & Fe.wu & K-M flipped & 10 & 0 & 78 & 3,000 & 1,350 & 2,700 \\
\hline $35 \mathrm{~A}$ & A72 & Animas River downstream from Silverton & Animas & Fe.wu & K-M flipped & 92 & 0 & 78 & 20,000 & 2,590 & 4,280 \\
\hline $39 \mathrm{~A}$ & 9445 & Cascade Creek at Highway 550 & Animas & Fe.wu & ROS & 16 & 12 & $<10$ & 1,200 & 1.6 & 51 \\
\hline $41 \mathrm{~A}$ & DRALP003 & Animas at Durango Mall & Animas & Fe.wu & K-M flipped & 86 & 29 & $<50$ & 10,050 & 116 & 600 \\
\hline $43 \mathrm{~A}$ & 9440 & Falls Creek at 0.65 Road & Animas & Fe.wu & K-M flipped & 13 & 5 & $<10$ & 460 & 31 & 120 \\
\hline $46 \mathrm{~A}$ & 9420 & Animas River at Durango & Animas & Fe.wu & K-M flipped & 30 & 0 & 85 & 6,500 & 215 & 2,600 \\
\hline $47 \mathrm{~A}$ & DRALPLC2 & Lightner Creek at mouth at Durango & Animas & Fe.wu & K-M flipped & 42 & 4 & $<50$ & 3,700 & 297 & 768 \\
\hline $48 \mathrm{~A}$ & DRALP001 & DRALP001 & Animas & Fe.wu & K-M flipped & 87 & 25 & $<50$ & 6,169 & 108 & 490 \\
\hline $49 \mathrm{~A}$ & DRALP002 & Animas River at Durango & Animas & Fe.wu & K-M flipped & 112 & 28 & $<50$ & 5,395 & 204 & 720 \\
\hline
\end{tabular}


Table 8. Summary of selected trace element concentrations at sites with 10 or more samples in the Dolores, Upper San Juan, and Lower San Juan River Basins, southwestern Colorado, 1990-2005.-Continued

[Site ID, site identification number shown on figure 1; Database ID, data repository identification number; <, less than; concentrations are given in micrograms per liter; K-M flipped, Kaplan-Meier method modified for left-censored data used to compute summary statistics; ROS, the robust "regression on order statistics" method used to compute summary statistics; Estimate, summary statistics were reported as less than the maximum reporting limit; N, number of samples; NC, number of samples with concentrations reported as less than the reporting limit; Min, minimum value; Max, maximum value; Med, median; $\mathrm{C}_{85}$, 85th percentile concentration; Al.wf, dissolved aluminum; Al.wu, total recoverable aluminum; Fe.wf, dissolved iron; Fe.wu, total recoverable iron; Hg.wf, dissolved mercury; Hg.wu, total recoverable mercury; Pb.wf, dissolved lead; Pb.wu, total recoverable lead; Se.wf, dissolved selenium; Se.wu, total recoverable selenium; Ur.wf, dissolved uranium; Zn.wf, dissolved zinc; Zn.wu, total recoverable zinc; WWTP, wastewater treatment plant; values shown in blue indicate that chronic State water-quality standards were not met and values shown in red indicate that acute and chronic State water-quality standards were not met]

\begin{tabular}{|c|c|c|c|c|c|c|c|c|c|c|c|}
\hline $\begin{array}{l}\text { Site } \\
\text { ID }\end{array}$ & $\begin{array}{l}\text { Database } \\
\text { ID }\end{array}$ & Site name & $\begin{array}{c}\text { Subbasin } \\
\text { name }\end{array}$ & $\begin{array}{c}\text { Con- } \\
\text { stituent }\end{array}$ & Method & $\mathbf{N}$ & NC & Min & Max & Med & $\mathbf{C}_{85}$ \\
\hline \multicolumn{12}{|c|}{ Upper San Juan River Basin-Continued } \\
\hline $54 \mathrm{~A}$ & 9415 & Salt Creek at 309A Road & Animas & Fe.wu & K-M flipped & 15 & 0 & 270 & 5,300 & 770 & 2,200 \\
\hline $01 \mathrm{U}$ & 9850 & Little Navajo River at Highway 84 & Upper San Juan & Fe.wu & K-M flipped & 16 & 0 & 81 & 18,000 & 325 & 1,000 \\
\hline $03 \mathrm{U}$ & 9860 & Rio Blanco at Highway 84 & Upper San Juan & Fe.wu & K-M flipped & 17 & 2 & $<50$ & 12,000 & 140 & 490 \\
\hline $05 \mathrm{U}$ & 9165 & Sand Creek at mouth above East Fork San Juan River & Upper San Juan & Fe.wu & K-M flipped & 12 & 0 & 16 & 1,500 & 34 & 160 \\
\hline $10 \mathrm{U}$ & 9120 & McCabe Creek above Pagosa Springs & Upper San Juan & Fe.wu & K-M flipped & 17 & 0 & 140 & 2,500 & 1,000 & 1,500 \\
\hline $15 \mathrm{U}$ & 9290 & East Fork Piedra River below Piedra Falls & Piedra & Fe.wu & K-M flipped & 12 & 0 & 17 & 270 & 43 & 130 \\
\hline $16 \mathrm{U}$ & 9250 & Piedra River at Highway 160 & Piedra & Fe.wu & K-M flipped & 53 & 0 & 41 & 2,500 & 160 & 620 \\
\hline $17 \mathrm{U}$ & 9245 & Stollsteimer Creek at Highway 151 & Piedra & Fe.wu & K-M flipped & 18 & 0 & 81 & 2,300 & 335 & 1,500 \\
\hline $21 U$ & 9380 & Los Pinos River above Vallecito Reservoir & Upper San Juan & Fe.wu & K-M flipped & 52 & 0 & 12 & 560 & 48 & 160 \\
\hline $23 \mathrm{U}$ & 9370 & Vallecito Creek near mouth & Upper San Juan & Fe.wu & K-M flipped & 51 & 12 & $<10$ & 750 & 26 & 89 \\
\hline $25 \mathrm{U}$ & 9355 & Wallace Gulch at 502 Road north of Bayfield & Upper San Juan & Fe.wu & K-M flipped & 16 & 0 & 260 & 2,400 & 620 & 2,000 \\
\hline $30 \mathrm{U}$ & 9680 & La Plata at Hesperus & Middle San Juan & Fe.wu & K-M flipped & 41 & 4 & $<10$ & 2,500 & 32 & 62 \\
\hline $31 \mathrm{U}$ & 9610 & Spring Creek near Breen & Middle San Juan & Fe.wu & K-M flipped & 12 & 0 & 130 & 830 & 230 & 350 \\
\hline $32 \mathrm{U}$ & 9720 & East Fork Mancos River at 44 Road & Mancos & Fe.wu & K-M flipped & 22 & 1 & $<10$ & 5,000 & 45.5 & 500 \\
\hline $34 \mathrm{U}$ & 9715 & Chicken Creek at Mancos & Mancos & Fe.wu & K-M flipped & 18 & 0 & 180 & 1,200 & 325 & 1,100 \\
\hline 07A & A68 & Animas River at Silverton & Animas & Hg.wf & Estimate & 31 & 29 & $<0.1$ & $<1$ & $<1$ & $<1$ \\
\hline 09A & CC18 & $\begin{array}{l}\text { North Fork Cement Creek upstream from Gold King mine, } \\
\text { \#7 level (AMLI mine \# 103) }\end{array}$ & Animas & Hg.wf & Estimate & 91 & 90 & $<1$ & $<2$ & $<2$ & $<2$ \\
\hline $15 \mathrm{~A}$ & $\mathrm{CC} 20$ & Porcupine Gulch upstream from mines & Animas & Hg.wf & Estimate & 113 & 107 & $<0.2$ & $<2$ & $<2$ & $<2$ \\
\hline $32 \mathrm{~A}$ & M34 & Mineral Creek at Silverton & Animas & Hg.wf & Estimate & 30 & 29 & $<0.05$ & $<1$ & $<1$ & $<1$ \\
\hline $33 \mathrm{~A}$ & 09359020 & Animas River below Silverton & Animas & Hg.wf & Estimate & 36 & 33 & $<0.0055$ & $<0.23$ & $<0.23$ & $<0.23$ \\
\hline $41 \mathrm{~A}$ & DRALP003 & Animas at Durango Mall & Animas & Hg.wf & Estimate & 60 & 58 & $<0.1$ & $<1$ & $<1$ & $<1$ \\
\hline $46 \mathrm{~A}$ & 9420 & Animas River at Durango & Animas & Hg.wf & Estimate & 27 & 27 & $<0.1$ & $<0.2$ & $<0.2$ & $<0.2$ \\
\hline $47 \mathrm{~A}$ & DRALPLC2 & Lightner Creek at mouth at Durango & Animas & Hg.wf & Estimate & 49 & 46 & $<0.05$ & 0.22 & $<0.2$ & $<0.2$ \\
\hline $48 \mathrm{~A}$ & DRALP001 & DRALP001 & Animas & Hg.wf & Estimate & 84 & 83 & $<0.06$ & 2.27 & $<1$ & $<1$ \\
\hline $49 \mathrm{~A}$ & DRALP002 & Animas River at Durango & Animas & Hg.wf & Estimate & 124 & 119 & $<0.05$ & 2 & $<1$ & $<1$ \\
\hline $50 \mathrm{~A}$ & DRALP209 & Animas River behind BMX track at Durango & Animas & Hg.wf & Estimate & 21 & 21 & $<0.06$ & $<0.2$ & $<0.2$ & $<0.2$ \\
\hline $16 \mathrm{U}$ & 9250 & Piedra River at Highway 160 & Piedra & Hg.wf & Estimate & 29 & 29 & $<0.01$ & $<0.2$ & $<0.2$ & $<0.2$ \\
\hline $21 \mathrm{U}$ & 9380 & Los Pinos River above Vallecito Reservoir & Upper San Juan & Hg.wf & Estimate & 29 & 29 & $<0.1$ & $<0.2$ & $<0.2$ & $<0.2$ \\
\hline $23 \mathrm{U}$ & 9370 & Vallecito Creek near mouth & Upper San Juan & Hg.wf & Estimate & 28 & 28 & $<0.1$ & $<0.2$ & $<0.2$ & $<0.2$ \\
\hline $30 \mathrm{U}$ & 9680 & La Plata at Hesperus & Middle San Juan & Hg.wf & Estimate & 17 & 17 & $<0.1$ & $<0.2$ & $<0.2$ & $<0.2$ \\
\hline 07A & A68 & Animas River at Silverton & Animas & Hg.wu & ROS & 33 & 29 & $<0.05$ & $<1$ & 0.11 & 0.18 \\
\hline $32 \mathrm{~A}$ & M34 & Mineral Creek at Silverton & Animas & Hg.wu & Estimate & 32 & 31 & $<0.05$ & $<1$ & $<1$ & $<1$ \\
\hline
\end{tabular}


Table 8. Summary of selected trace element concentrations at sites with 10 or more samples in the Dolores, Upper San Juan, and Lower San Juan River Basins, southwestern Colorado, 1990-2005.-Continued

[Site ID, site identification number shown on figure 1; Database ID, data repository identification number; <, less than; concentrations are given in micrograms per liter; K-M flipped, Kaplan-Meier method modified for left-censored data used to compute summary statistics; ROS, the robust "regression on order statistics" method used to compute summary statistics; Estimate, summary statistics were reported as less than the maximum reporting limit; N, number of samples; NC, number of samples with concentrations reported as less than the reporting limit; Min, minimum value; Max, maximum value; Med, median; $\mathrm{C}_{85}$, 85th percentile concentration; Al.wf, dissolved aluminum; Al.wu, total recoverable aluminum; Fe.wf, dissolved iron; Fe.wu, total recoverable iron; Hg.wf, dissolved mercury; Hg.wu, total recoverable mercury; Pb.wf, dissolved lead; Pb.wu, total recoverable lead; Se.wf, dissolved selenium; Se.wu, total recoverable selenium; Ur.wf, dissolved uranium; $\mathrm{Zn}$.wf, dissolved zinc; $\mathrm{Zn}$.wu, total recoverable zinc; $\mathrm{WWTP}$ wastewater treatment plant; values shown in blue indicate that chronic State water-quality standards were not met and values shown in red indicate that acute and chronic State water-quality standards were not met]

\begin{tabular}{|c|c|c|c|c|c|c|c|c|c|c|c|}
\hline $\begin{array}{c}\text { Site } \\
\text { ID }\end{array}$ & $\begin{array}{c}\text { Database } \\
\text { ID } \\
\end{array}$ & Site name & $\begin{array}{c}\text { Subbasin } \\
\text { name }\end{array}$ & $\begin{array}{c}\text { Con- } \\
\text { stituent }\end{array}$ & Method & $\mathbf{N}$ & NC & Min & Max & Med & $\mathbf{C}_{85}$ \\
\hline \multicolumn{12}{|c|}{ Upper San Juan River Basin-Continued } \\
\hline $36 \mathrm{~A}$ & 000082 & Animas River near Silverton & Animas & Hg.wu & Estimate & 11 & 11 & $<0.2$ & $<0.2$ & $<0.2$ & $<0.2$ \\
\hline $39 \mathrm{~A}$ & 9445 & Cascade Creek at Highway 550 & Animas & Hg.wu & Estimate & 13 & 13 & $<0.2$ & $<0.2$ & $<0.2$ & $<0.2$ \\
\hline $41 \mathrm{~A}$ & DRALP003 & Animas at Durango Mall & Animas & Hg.wu & ROS & 85 & 76 & $<0.1$ & $<1$ & 0.1 & 0.19 \\
\hline $43 \mathrm{~A}$ & 9440 & Falls Creek at 0.65 Road & Animas & Hg.wu & Estimate & 11 & 11 & $<0.2$ & $<0.2$ & $<0.2$ & $<0.2$ \\
\hline $47 \mathrm{~A}$ & DRALPLC2 & Lightner Creek at mouth at Durango & Animas & Hg.wu & ROS & 50 & 38 & $<0.05$ & $<1$ & 0.11 & 0.22 \\
\hline $48 \mathrm{~A}$ & DRALP001 & DRALP001 & Animas & Hg.wu & Estimate & 107 & 99 & $<0.06$ & 5.39 & $<1$ & $<1$ \\
\hline $49 \mathrm{~A}$ & DRALP002 & Animas River at Durango & Animas & Hg.wu & Estimate & 149 & 137 & $<0.05$ & 3.5 & $<1$ & $<1$ \\
\hline $50 \mathrm{~A}$ & DRALP209 & Animas River behind BMX track at Durango & Animas & Hg.wu & Estimate & 21 & 21 & $<0.06$ & $<0.2$ & $<0.06$ & $<0.2$ \\
\hline $54 \mathrm{~A}$ & 9415 & Salt Creek at 309A Road & Animas & Hg.wu & Estimate & 14 & 14 & $<0.2$ & $<0.2$ & $<0.2$ & $<0.2$ \\
\hline $57 \mathrm{~A}$ & 000066 & Animas River near Bondad & Animas & Hg.wu & Estimate & 19 & 19 & $<0.2$ & $<0.2$ & $<0.2$ & $<0.2$ \\
\hline $01 \mathrm{U}$ & 9850 & Little Navajo River at Highway 84 & Upper San Juan & Hg.wu & Estimate & 13 & 13 & $<0.2$ & $<0.2$ & $<0.2$ & $<0.2$ \\
\hline $03 \mathrm{U}$ & 9860 & Rio Blanco at Highway 84 & Upper San Juan & Hg.wu & Estimate & 14 & 14 & $<0.2$ & $<0.2$ & $<0.2$ & $<0.2$ \\
\hline $10 \mathrm{U}$ & 9120 & McCabe Creek above Pagosa Springs & Upper San Juan & Hg.wu & Estimate & 14 & 14 & $<0.2$ & $<0.2$ & $<0.2$ & $<0.2$ \\
\hline $16 \mathrm{U}$ & 9250 & Piedra River at Highway 160 & Piedra & Hg.wu & Estimate & 21 & 21 & $<0.2$ & $<0.2$ & $<0.2$ & $<0.2$ \\
\hline $17 \mathrm{U}$ & 9245 & Stollsteimer Creek at Highway 151 & Piedra & Hg.wu & Estimate & 15 & 15 & $<0.2$ & $<0.2$ & $<0.2$ & $<0.2$ \\
\hline $21 \mathrm{U}$ & 9380 & Los Pinos River above Vallecito Reservoir & Upper San Juan & Hg.wu & Estimate & 18 & 18 & $<0.2$ & $<0.2$ & $<0.2$ & $<0.2$ \\
\hline $23 \mathrm{U}$ & 9370 & Vallecito Creek near mouth & Upper San Juan & Hg.wu & Estimate & 19 & 19 & $<0.2$ & $<0.2$ & $<0.2$ & $<0.2$ \\
\hline $25 \mathrm{U}$ & 9355 & Wallace Gulch at 502 Road north of Bayfield & Upper San Juan & Hg.wu & Estimate & 13 & 13 & $<0.2$ & $<0.2$ & $<0.2$ & $<0.2$ \\
\hline $30 \mathrm{U}$ & 9680 & La Plata at Hesperus & Middle San Juan & Hg.wu & Estimate & 21 & 21 & $<0.2$ & $<0.2$ & $<0.2$ & $<0.2$ \\
\hline $31 \mathrm{U}$ & 9610 & Spring Creek near Breen & Middle San Juan & Hg.wu & Estimate & 12 & 12 & $<0.2$ & $<0.2$ & $<0.2$ & $<0.2$ \\
\hline $32 \mathrm{U}$ & 9720 & East Fork Mancos River at 44 Road & Mancos & Hg.wu & Estimate & 11 & 11 & $<0.2$ & $<0.2$ & $<0.2$ & $<0.2$ \\
\hline $34 \mathrm{U}$ & 9715 & Chicken Creek at Mancos & Mancos & Hg.wu & Estimate & 14 & 14 & $<0.2$ & $<0.2$ & $<0.2$ & $<0.2$ \\
\hline $01 \mathrm{~A}$ & A09 & North Fork above Cal. Gulch & Animas & Pb.wf & ROS & 11 & 8 & $<0.8$ & 17 & 1.98 & 7 \\
\hline $02 \mathrm{~A}$ & A33 & Animas River at Eureka & Animas & Pb.wf & Estimate & 24 & 22 & $<0.6$ & 150 & $<30$ & $<30$ \\
\hline 03A & A39 & Eureka below Ben Franklin & Animas & Pb.wf & K-M flipped & 24 & 6 & $<5$ & 40 & 9 & 20 \\
\hline $04 \mathrm{~A}$ & A53 & Animas River at Howardsville & Animas & Pb.wf & Estimate & 18 & 16 & $<0.6$ & $<30$ & $<30$ & $<30$ \\
\hline $05 \mathrm{~A}$ & A60 & Animas River downstream from Arrastra Gulch & Animas & Pb.wf & Estimate & 12 & 12 & $<5$ & $<30$ & $<30$ & $<30$ \\
\hline $07 \mathrm{~A}$ & A68 & Animas River at Silverton & Animas & Pb.wf & Estimate & 159 & 143 & $<0.2$ & 52 & $<30$ & $<30$ \\
\hline $09 \mathrm{~A}$ & $\mathrm{CC} 18$ & $\begin{array}{l}\text { North Fork Cement Creek upstream from Gold King mine, } \\
\text { \#7 level (AMLI mine \# 103) }\end{array}$ & Animas & Pb.wf & K-M flipped & 95 & 17 & $<1$ & 440 & 10 & 110 \\
\hline $10 \mathrm{~A}$ & $\mathrm{CC} 32$ & South Fork Cement Creek downstream from Velocity Lake & Animas & Pb.wf & Estimate & 15 & 14 & $<0.8$ & 38 & $<30$ & $<30$ \\
\hline $11 \mathrm{~A}$ & $\mathrm{CC} 31$ & $\begin{array}{l}\text { South Fork Cement Creek downstream from Big Colorado mine } \\
\text { (AMLI mine \# 150) }\end{array}$ & Animas & Pb.wf & Estimate & 14 & 12 & $<30$ & $<30$ & $<30$ & $<30$ \\
\hline $12 \mathrm{~A}$ & $\mathrm{CC} 23$ & Prospect Gulch upstream from Red Spring & Animas & $\mathrm{Pb} . w f$ & K-M flipped & 16 & 2 & $<5$ & 160 & 13.5 & 40 \\
\hline
\end{tabular}


Table 8. Summary of selected trace element concentrations at sites with 10 or more samples in the Dolores, Upper San Juan, and Lower San Juan River Basins, southwestern Colorado, 1990-2005.-Continued

[Site ID, site identification number shown on figure 1; Database ID, data repository identification number; <, less than; concentrations are given in micrograms per liter; K-M flipped, Kaplan-Meier method modified for left-censored data used to compute summary statistics; ROS, the robust "regression on order statistics" method used to compute summary statistics; Estimate, summary statistics were reported as less than the maximum reporting limit; N, number of samples; NC, number of samples with concentrations reported as less than the reporting limit; Min, minimum value; Max, maximum value; Med, median; $\mathrm{C}_{85}$, 85th percentile concentration; Al.wf, dissolved aluminum; Al.wu, total recoverable aluminum; Fe.wf, dissolved iron; Fe.wu, total recoverable iron; Hg.wf, dissolved mercury; Hg.wu, total recoverable mercury; Pb.wf, dissolved lead; Pb.wu, total recoverable lead; Se.wf, dissolved selenium; Se.wu, total recoverable selenium; Ur.wf, dissolved uranium; Zn.wf, dissolved zinc; Zn.wu, total recoverable zinc; WWTP, wastewater treatment plant; values shown in blue indicate that chronic State water-quality standards were not met and values shown in red indicate that acute and chronic State water-quality standards were not met]

\begin{tabular}{|c|c|c|c|c|c|c|c|c|c|c|c|}
\hline $\begin{array}{l}\text { Site } \\
\text { ID }\end{array}$ & $\begin{array}{l}\text { Database } \\
\text { ID }\end{array}$ & Site name & $\begin{array}{c}\text { Subbasin } \\
\text { name }\end{array}$ & $\begin{array}{c}\text { Con- } \\
\text { stituent }\end{array}$ & Method & $\mathbf{N}$ & NC & Min & Max & Med & $\mathrm{C}_{85}$ \\
\hline \multicolumn{12}{|c|}{ Upper San Juan River Basin-Continued } \\
\hline $14 \mathrm{~A}$ & CC14 & Minnesota Gulch near mouth & Animas & Pb.wf & ROS & 12 & 9 & $<5$ & $<30$ & 1.24 & 5.09 \\
\hline $15 \mathrm{~A}$ & $\mathrm{CC} 20$ & Porcupine Gulch upstream from mines & Animas & Pb.wf & ROS & 121 & 70 & $<4$ & 200 & 3.92 & 20 \\
\hline $16 \mathrm{~A}$ & $\mathrm{CC} 17$ & Niagara Gulch near mouth & Animas & Pb.wf & ROS & 32 & 28 & $<0.8$ & 56 & 0.98 & 6.14 \\
\hline $19 \mathrm{~A}$ & CEM48 & Cement Creek at USGS gaging station & Animas & Pb.wf & K-M flipped & 11 & 0 & 5.5 & 31 & 15 & 27 \\
\hline $20 \mathrm{~A}$ & M02 & Mineral Creek near headwaters & Animas & Pb.wf & K-M flipped & 16 & 0 & 41 & 300 & 110 & 238 \\
\hline $21 \mathrm{~A}$ & M02A & $\begin{array}{l}\text { Highway } 550 \text { drainage ditch above M01 confluence-east side } \\
\text { of Highway } 550\end{array}$ & Animas & Pb.wf & K-M flipped & 14 & 1 & $<5$ & 270 & 112 & 189 \\
\hline $22 \mathrm{~A}$ & M07 & Mineral Creek at Chattanooga & Animas & Pb.wf & K-M flipped & 16 & 5 & $<5$ & 800 & 48 & 250 \\
\hline $23 \mathrm{~A}$ & M13 & Mineral Creek just below confluence with Browns Gulch & Animas & Pb.wf & ROS & 15 & 10 & $<30$ & 109 & 8.23 & 27 \\
\hline $30 \mathrm{~A}$ & M27 & Mineral Creek above confluence with South Fork Mineral Creek & Animas & Pb.wf & ROS & 16 & 9 & $<1$ & 39 & 10.5 & 23 \\
\hline $32 \mathrm{~A}$ & M34 & Mineral Creek at Silverton & Animas & Pb.wf & ROS & 152 & 131 & $<0.2$ & 62 & 0.48 & 2.7 \\
\hline $33 \mathrm{~A}$ & 09359020 & Animas River below Silverton & Animas & Pb.wf & ROS & 44 & 35 & $<0.04$ & 1 & 0.09 & 0.36 \\
\hline $35 \mathrm{~A}$ & A72 & Animas River downstream from Silverton & Animas & Pb.wf & Estimate & 211 & 194 & $<0.2$ & $<40$ & $<40$ & $<40$ \\
\hline $39 \mathrm{~A}$ & 9445 & Cascade Creek at Highway 550 & Animas & Pb.wf & Estimate & 16 & 16 & $<1$ & $<1$ & $<1$ & $<1$ \\
\hline $41 \mathrm{~A}$ & DRALP003 & Animas at Durango Mall & Animas & Pb.wf & Estimate & 60 & 56 & $<1$ & 32 & $<5$ & $<5$ \\
\hline $43 \mathrm{~A}$ & 9440 & Falls Creek at 0.65 Road & Animas & Pb.wf & Estimate & 13 & 13 & $<1$ & $<1$ & $<1$ & $<1$ \\
\hline $46 \mathrm{~A}$ & 9420 & Animas River at Durango & Animas & Pb.wf & Estimate & 30 & 28 & $<1$ & 11 & $<1$ & $<1$ \\
\hline $47 \mathrm{~A}$ & DRALPLC2 & Lightner Creek at mouth at Durango & Animas & Pb.wf & Estimate & 46 & 44 & $<0.2$ & 7 & $<5$ & $<5$ \\
\hline $48 \mathrm{~A}$ & DRALP001 & DRALP001 & Animas & Pb.wf & Estimate & 81 & 79 & $<1$ & 39 & $<5$ & $<5$ \\
\hline $49 \mathrm{~A}$ & DRALP002 & Animas River at Durango & Animas & Pb.wf & Estimate & 121 & 117 & $<0.2$ & 41 & $<7.5$ & $<7.5$ \\
\hline $50 \mathrm{~A}$ & DRALP209 & Animas River behind BMX track at Durango & Animas & Pb.wf & Estimate & 21 & 21 & $<1$ & $<1$ & $<1$ & $<1$ \\
\hline $54 \mathrm{~A}$ & 9415 & Salt Creek at 309A Road & Animas & Pb.wf & Estimate & 15 & 15 & $<1$ & $<1$ & $<1$ & $<1$ \\
\hline $01 \mathrm{U}$ & 9850 & Little Navajo River at Highway 84 & Upper San Juan & Pb.wf & Estimate & 16 & 16 & $<1$ & $<1$ & $<1$ & $<1$ \\
\hline $03 \mathrm{U}$ & 9860 & Rio Blanco at Highway 84 & Upper San Juan & Pb.wf & Estimate & 17 & 16 & $<1$ & 11 & $<1$ & $<1$ \\
\hline $05 \mathrm{U}$ & 9165 & Sand Creek at mouth above East Fork San Juan River & Upper San Juan & Pb.wf & Estimate & 12 & 12 & $<1$ & $<1$ & $<1$ & $<1$ \\
\hline $10 U$ & 9120 & McCabe Creek above Pagosa Springs & Upper San Juan & Pb.wf & Estimate & 17 & 17 & $<1$ & $<1$ & $<1$ & $<1$ \\
\hline $15 \mathrm{U}$ & 9290 & East Fork Piedra River below Piedra Falls & Piedra & Pb.wf & Estimate & 12 & 12 & $<1$ & $<1$ & $<1$ & $<1$ \\
\hline $16 U$ & 9250 & Piedra River at Highway 160 & Piedra & Pb.wf & Estimate & 53 & 51 & $<0.1$ & 12 & $<2$ & $<2$ \\
\hline $17 \mathrm{U}$ & 9245 & Stollsteimer Creek at Highway 151 & Piedra & Pb.wf & Estimate & 18 & 18 & $<1$ & $<1$ & $<1$ & $<1$ \\
\hline $20 U$ & 09352800 & Los Pinos River above Vallecito Reservoir near Bayfield & Upper San Juan & Pb.wf & Estimate & 10 & 10 & $<0.04$ & $<9.1$ & $<9.1$ & $<9.1$ \\
\hline $21 U$ & 9380 & Los Pinos River above Vallecito Reservoir & Upper San Juan & Pb.wf & Estimate & 52 & 51 & $<0.1$ & 8 & $<1$ & $<1$ \\
\hline $22 U$ & 09352900 & Vallecito Creek near Bayfield & Upper San Juan & Pb.wf & Estimate & 20 & 18 & $<0.04$ & $<10$ & $<10$ & $<10$ \\
\hline $23 \mathrm{U}$ & 9370 & Vallecito Creek near mouth & Upper San Juan & Pb.wf & Estimate & 52 & 51 & $<1$ & 17 & $<1$ & $<1$ \\
\hline $24 U$ & 372236107344400 & Los Pinos River below Vallecito Reservoir near Bayfield & Upper San Juan & Pb.wf & Estimate & 14 & 14 & $<0.04$ & $<9.1$ & $<9.1$ & $<9.1$ \\
\hline $25 \mathrm{U}$ & 9355 & Wallace Gulch at 502 Road north of Bayfield & Upper San Juan & Pb.wf & Estimate & 16 & 16 & $<1$ & $<1$ & $<1$ & $<1$ \\
\hline
\end{tabular}


Table 8. Summary of selected trace element concentrations at sites with 10 or more samples in the Dolores, Upper San Juan, and Lower San Juan River Basins, southwestern Colorado, 1990-2005.-Continued

[Site ID, site identification number shown on figure 1; Database ID, data repository identification number; <, less than; concentrations are given in micrograms per liter; K-M flipped, Kaplan-Meier method modified for left-censored data used to compute summary statistics; ROS, the robust "regression on order statistics" method used to compute summary statistics; Estimate, summary statistics were reported as less than the maximum reporting limit; N, number of samples; NC, number of samples with concentrations reported as less than the reporting limit; Min, minimum value; Max, maximum value; Med, median; $\mathrm{C}_{85}$, 85th percentile concentration; Al.wf, dissolved aluminum; Al.wu, total recoverable aluminum; Fe.wf, dissolved iron; Fe.wu; total recoverable iron; Hg.wf, dissolved mercury; Hg.wu, total recoverable mercury; Pb.wf, dissolved lead; Pb.wu, total recoverable lead; Se.wf, dissolved selenium; Se.wu, total recoverable selenium; Ur.wf, dissolved uranium; Zn.wf, dissolved zinc; Zn.wu, total recoverable zinc; WWTP, wastewater treatment plant; values shown in blue indicate that chronic State water-quality standards were not met and values shown in red indicate that acute and chronic State water-quality standards were not met]

\begin{tabular}{|c|c|c|c|c|c|c|c|c|c|c|c|}
\hline $\begin{array}{l}\text { Site } \\
\text { ID }\end{array}$ & $\begin{array}{l}\text { Database } \\
\text { ID }\end{array}$ & Site name & $\begin{array}{l}\text { Subbasin } \\
\text { name }\end{array}$ & $\begin{array}{c}\text { Con- } \\
\text { stituent }\end{array}$ & Method & $\mathbf{N}$ & NC & Min & Max & Med & $\mathrm{C}_{85}$ \\
\hline \multicolumn{12}{|c|}{ Upper San Juan River Basin—Continued } \\
\hline $30 \mathrm{U}$ & 9680 & La Plata at Hesperus & Middle San Juan & Pb.wf & Estimate & 42 & 42 & $<0.1$ & $<1$ & $<1$ & $<1$ \\
\hline $31 \mathrm{U}$ & 9610 & Spring Creek near Breen & Middle San Juan & Pb.wf & Estimate & 12 & 12 & $<1$ & $<1$ & $<1$ & $<1$ \\
\hline $32 \mathrm{U}$ & 9720 & East Fork Mancos River at 44 Road & Mancos & Pb.wf & Estimate & 22 & 21 & $<1$ & $<5$ & $<5$ & $<5$ \\
\hline $34 U$ & 9715 & Chicken Creek at Mancos & Mancos & Pb.wf & Estimate & 18 & 18 & $<1$ & $<2$ & $<2$ & $<2$ \\
\hline $02 \mathrm{~A}$ & A33 & Animas River at Eureka & Animas & $\mathrm{Pb} . w u$ & K-M flipped & 10 & 2 & $<30$ & $<30$ & 5.71 & 6.4 \\
\hline 07A & A68 & Animas River at Silverton & Animas & Pb.wu & K-M flipped & 96 & 31 & $<1$ & 166 & 4 & 30 \\
\hline $10 \mathrm{~A}$ & $\mathrm{CC} 32$ & South Fork Cement Creek downstream from Velocity Lake & Animas & $\mathrm{Pb} . w u$ & Estimate & 10 & 9 & $<30$ & $<30$ & $<30$ & $<30$ \\
\hline $15 \mathrm{~A}$ & $\mathrm{CC} 20$ & Porcupine Gulch upstream from mines & Animas & $\mathrm{Pb} . w u$ & K-M flipped & 12 & 0 & 12 & 580 & 35 & 200 \\
\hline $19 \mathrm{~A}$ & CEM48 & Cement Creek at USGS gaging station & Animas & Pb.wu & K-M flipped & 12 & 0 & 12 & 61 & 15 & 47 \\
\hline $30 \mathrm{~A}$ & M27 & Mineral Creek above confluence with South Fork Mineral Creek & Animas & $\mathrm{Pb} . w u$ & K-M flipped & 15 & 6 & $<30$ & 87 & 12 & 23 \\
\hline $32 \mathrm{~A}$ & M34 & Mineral Creek at Silverton & Animas & Pb.wu & K-M flipped & 115 & 43 & $<1$ & 66 & 7 & 14 \\
\hline $34 \mathrm{~A}$ & AN72 & Animas River at USGS gaging station just above railroad bridge & Animas & Pb.wu & K-M flipped & 10 & 0 & 5 & 28 & 10.5 & 25 \\
\hline $35 \mathrm{~A}$ & A72 & Animas River downstream from Silverton & Animas & Pb.wu & ROS & 63 & 32 & $<22.5$ & 53 & 10 & 22 \\
\hline $41 \mathrm{~A}$ & DRALP003 & Animas at Durango Mall & Animas & $\mathrm{Pb} . w u$ & ROS & 85 & 49 & $<1$ & 701 & 3 & 8 \\
\hline $47 \mathrm{~A}$ & DRALPLC2 & Lightner Creek at mouth at Durango & Animas & $\mathrm{Pb} . w u$ & ROS & 48 & 32 & $<0.2$ & 20 & 1.85 & 6 \\
\hline $48 \mathrm{~A}$ & DRALP001 & DRALP001 & Animas & Pb.wu & ROS & 106 & 63 & $<1$ & 424 & 1.21 & 8 \\
\hline $49 \mathrm{~A}$ & DRALP002 & Animas River at Durango & Animas & Pb.wu & ROS & 148 & 90 & $<1$ & 334 & 1 & 8 \\
\hline $50 \mathrm{~A}$ & DRALP209 & Animas River behind BMX track at Durango & Animas & $\mathrm{Pb} . w u$ & ROS & 21 & 16 & $<1$ & 2,680 & 0.007 & 6.9 \\
\hline $01 \mathrm{~A}$ & A09 & North Fork above Cal. Gulch & Animas & Zn.wf & K-M flipped & 11 & 0 & 320 & 870 & 328 & 790 \\
\hline $02 \mathrm{~A}$ & A33 & Animas River at Eureka & Animas & Zn.wf & K-M flipped & 24 & 0 & 239 & 573 & 404 & 514 \\
\hline $03 \mathrm{~A}$ & A39 & Eureka below Ben Franklin & Animas & Zn.wf & K-M flipped & 24 & 0 & 380 & 2,730 & 830 & 1,480 \\
\hline $04 \mathrm{~A}$ & A53 & Animas River at Howardsville & Animas & Zn.wf & K-M flipped & 18 & 0 & 197 & 366 & 270 & 314 \\
\hline $05 \mathrm{~A}$ & A60 & Animas River downstream from Arrastra Gulch & Animas & Zn.wf & K-M flipped & 12 & 0 & 159 & 320 & 249 & 320 \\
\hline $06 \mathrm{~A}$ & AN68 & Animas River at USGS gaging station above 14th Street & Animas & Zn.wf & K-M flipped & 12 & 0 & 290 & 450 & 345 & 420 \\
\hline 07A & A68 & Animas River at Silverton & Animas & Zn.wf & K-M flipped & 160 & 0 & 110 & 1,900 & 490 & 824 \\
\hline 09A & $\mathrm{CC} 18$ & $\begin{array}{l}\text { North Fork Cement Creek upstream from Gold King mine, } \\
\quad \# 7 \text { level (AMLI mine \# 103) }\end{array}$ & Animas & Zn.wf & K-M flipped & 95 & 0 & 64 & 8,400 & 3,420 & 5,640 \\
\hline $10 \mathrm{~A}$ & $\mathrm{CC} 32$ & South Fork Cement Creek downstream from Velocity Lake & Animas & Zn.wf & K-M flipped & 16 & 1 & $<20$ & 285 & 168 & 215 \\
\hline $11 \mathrm{~A}$ & $\mathrm{CC} 31$ & $\begin{array}{l}\text { South Fork Cement Creek downstream from Big Colorado mine } \\
\text { (AMLI mine \# 150) }\end{array}$ & Animas & Zn.wf & K-M flipped & 14 & 0 & 381 & 1,753 & 1,070 & 1,360 \\
\hline $12 \mathrm{~A}$ & $\mathrm{CC} 23$ & Prospect Gulch upstream from Red Spring & Animas & Zn.wf & K-M flipped & 16 & 0 & 358 & 2,400 & 384 & 1,020 \\
\hline $14 \mathrm{~A}$ & $\mathrm{CC} 14$ & Minnesota Gulch near mouth & Animas & Zn.wf & K-M flipped & 13 & 0 & 147 & 1,641 & 805 & 1,400 \\
\hline $15 \mathrm{~A}$ & $\mathrm{CC} 20$ & Porcupine Gulch upstream from mines & Animas & Zn.wf & K-M flipped & 124 & 3 & $<20$ & 11,500 & 935 & 2,090 \\
\hline $16 \mathrm{~A}$ & $\mathrm{CC} 17$ & Niagara Gulch near mouth & Animas & Zn.wf & K-M flipped & 33 & 0 & 93 & 2,020 & 870 & 1,250 \\
\hline
\end{tabular}


Table 8. Summary of selected trace element concentrations at sites with 10 or more samples in the Dolores, Upper San Juan, and Lower San Juan River Basins, southwestern Colorado, 1990-2005.-Continued

[Site ID, site identification number shown on figure 1; Database ID, data repository identification number; <, less than; concentrations are given in micrograms per liter; K-M flipped, Kaplan-Meier method modified for left-censored data used to compute summary statistics; ROS, the robust "regression on order statistics" method used to compute summary statistics; Estimate, summary statistics were reported as less than the maximum reporting limit; N, number of samples; $\mathrm{NC}$, number of samples with concentrations reported as less than the reporting limit; Min, minimum value; Max, maximum value; Med, median; $\mathrm{C}_{85}$, 85th percentile concentration; Al.wf, dissolved aluminum; Al.wu, total recoverable aluminum; Fe.wf, dissolved iron; Fe.wu. total recoverable iron; Hg.wf, dissolved mercury; Hg.wu, total recoverable mercury; Pb.wf, dissolved lead; Pb.wu, total recoverable lead; Se.wf, dissolved selenium; Se.wu, total recoverable selenium; Ur.wf, dissolved uranium; Zn.wf, dissolved zinc; Zn.wu, total recoverable zinc; WWTP, wastewater treatment plant; values shown in blue indicate that chronic State water-quality standards were not met and values shown in red indicate that acute and chronic State water-quality standards were not met]

\begin{tabular}{|c|c|c|c|c|c|c|c|c|c|c|c|}
\hline $\begin{array}{l}\text { Site } \\
\text { ID }\end{array}$ & $\begin{array}{l}\text { Database } \\
\text { ID }\end{array}$ & Site name & $\begin{array}{c}\text { Subbasin } \\
\text { name }\end{array}$ & $\begin{array}{c}\text { Con- } \\
\text { stituent }\end{array}$ & Method & $\mathbf{N}$ & NC & Min & Max & Med & $\mathrm{C}_{85}$ \\
\hline \multicolumn{12}{|c|}{ Upper San Juan River Basin-Continued } \\
\hline 19A & CEM48 & Cement Creek at USGS gaging station & Animas & Zn.wf & K-M flipped & 12 & 0 & 720 & 1,000 & 920 & 1,000 \\
\hline $20 \mathrm{~A}$ & M02 & Mineral Creek near headwaters & Animas & Zn.wf & K-M flipped & 16 & 0 & 12,000 & 230,000 & 100,500 & 180,000 \\
\hline $21 \mathrm{~A}$ & M02A & $\begin{array}{l}\text { Highway } 550 \text { drainage ditch above M01 confluence-east side } \\
\text { of Highway } 550\end{array}$ & Animas & Zn.wf & K-M flipped & 14 & 0 & 7,840 & 148,000 & 60,550 & 130,000 \\
\hline $22 \mathrm{~A}$ & M07 & Mineral Creek at Chattanooga & Animas & Zn.wf & K-M flipped & 16 & 0 & 180 & 8,900 & 1,645 & 5,800 \\
\hline $23 \mathrm{~A}$ & M13 & Mineral Creek just below confluence with Browns Gulch & Animas & Zn.wf & K-M flipped & 18 & 0 & 211 & 1,800 & 720 & 1,590 \\
\hline $24 \mathrm{~A}$ & M12 & Browns Gulch above confluence with Mineral Creek & Animas & Zn.wf & K-M flipped & 10 & 0 & 140 & 5,600 & 2,250 & 2,800 \\
\hline $29 \mathrm{~A}$ & M20 & Middle Fork Mineral Creek above Bonner Mine & Animas & Zn.wf & K-M flipped & 12 & 0 & 31 & 270 & 115 & 170 \\
\hline $30 \mathrm{~A}$ & M27 & Mineral Creek above confluence with South Fork Mineral Creek & Animas & Zn.wf & K-M flipped & 17 & 0 & 120 & 1,500 & 583 & 880 \\
\hline $32 \mathrm{~A}$ & M34 & Mineral Creek at Silverton & Animas & Zn.wf & K-M flipped & 168 & 0 & 37 & 750 & 270 & 443 \\
\hline $33 \mathrm{~A}$ & 09359020 & Animas River below Silverton & Animas & Zn.wf & K-M flipped & 44 & 0 & 188 & 830 & 442 & 589 \\
\hline $34 \mathrm{~A}$ & AN72 & Animas River at USGS gaging station just above railroad bridge & Animas & Zn.wf & K-M flipped & 24 & 0 & 200 & 790 & 370 & 670 \\
\hline $35 \mathrm{~A}$ & A72 & Animas River downstream from Silverton & Animas & Zn.wf & K-M flipped & 219 & 0 & 160 & 995 & 470 & 670 \\
\hline $39 \mathrm{~A}$ & 9445 & Cascade Creek at Highway 550 & Animas & Zn.wf & K-M flipped & 16 & 3 & $<10$ & 27 & 17 & 22 \\
\hline $41 \mathrm{~A}$ & DRALP003 & Animas at Durango Mall & Animas & Zn.wf & ROS & 61 & 36 & $<10$ & 70 & 10 & 44 \\
\hline $42 \mathrm{~A}$ & 89 & Trimble Lane Bridge & Animas & Zn.wf & K-M flipped & 13 & 0 & 10 & 290 & 63 & 127 \\
\hline $43 \mathrm{~A}$ & 9440 & Falls Creek at 0.65 Road & Animas & Zn.wf & K-M flipped & 13 & 2 & $<10$ & 54 & 15 & 25 \\
\hline $44 \mathrm{~A}$ & 135 & Animas at 32nd Street Bridge & Animas & Zn.wf & K-M flipped & 11 & 0 & 10 & 60 & 26 & 41 \\
\hline $46 \mathrm{~A}$ & 9420 & Animas River at Durango & Animas & Zn.wf & K-M flipped & 30 & 7 & $<10$ & 120 & 24.5 & 49 \\
\hline $47 \mathrm{~A}$ & DRALPLC2 & Lightner Creek at mouth at Durango & Animas & Zn.wf & ROS & 49 & 40 & $<10$ & 28 & 6.9 & 11 \\
\hline $48 \mathrm{~A}$ & DRALP001 & DRALP001 & Animas & Zn.wf & K-M flipped & 83 & 35 & $<10$ & 160 & 16 & 60 \\
\hline $49 \mathrm{~A}$ & DRALP002 & Animas River at Durango & Animas & Zn.wf & K-M flipped & 124 & 40 & $<10$ & 104 & 27 & 58 \\
\hline $50 \mathrm{~A}$ & DRALP209 & Animas River behind BMX track at Durango & Animas & Zn.wf & K-M flipped & 21 & 4 & $<10$ & 43 & 20 & 36 \\
\hline $54 \mathrm{~A}$ & 9415 & Salt Creek at 309A Road & Animas & Zn.wf & K-M flipped & 15 & 6 & $<10$ & 71 & 13 & 18 \\
\hline $01 \mathrm{U}$ & 9850 & Little Navajo River at Highway 84 & Upper San Juan & Zn.wf & K-M flipped & 16 & 6 & $<10$ & $<50$ & 14 & 22 \\
\hline $03 \mathrm{U}$ & 9860 & Rio Blanco at Highway 84 & Upper San Juan & Zn.wf & K-M flipped & 17 & 5 & $<10$ & $<100$ & 18 & 45 \\
\hline $05 \mathrm{U}$ & 9165 & Sand Creek at mouth above East Fork San Juan River & Upper San Juan & Zn.wf & ROS & 12 & 8 & $<10$ & 55 & 5.62 & 17 \\
\hline $10 \mathrm{U}$ & 9120 & McCabe Creek above Pagosa Springs & Upper San Juan & Zn.wf & K-M flipped & 17 & 6 & $<10$ & $<100$ & 21 & 77 \\
\hline $15 \mathrm{U}$ & 9290 & East Fork Piedra River below Piedra Falls & Piedra & Zn.wf & ROS & 12 & 9 & $<10$ & 13 & 9.52 & 12 \\
\hline $16 \mathrm{U}$ & 9250 & Piedra River at Highway 160 & Piedra & Zn.wf & ROS & 52 & 31 & $<10$ & 58 & 7.94 & 18 \\
\hline $17 \mathrm{U}$ & 9245 & Stollsteimer Creek at Highway 151 & Piedra & Zn.wf & K-M flipped & 18 & 8 & $<10$ & $<100$ & 24 & 39 \\
\hline $20 \mathrm{U}$ & 09352800 & Los Pinos River above Vallecito Reservoir near Bayfield & Upper San Juan & Zn.wf & Estimate & 12 & 11 & $<0.5$ & $<2$ & $<2$ & $<2$ \\
\hline $21 \mathrm{U}$ & 9380 & Los Pinos River above Vallecito Reservoir & Upper San Juan & Zn.wf & ROS & 52 & 35 & $<10$ & 24 & 8.84 & 15 \\
\hline $22 \mathrm{U}$ & 09352900 & Vallecito Creek near Bayfield & Upper San Juan & Zn.wf & K-M flipped & 26 & 4 & $<1$ & 24 & 3 & 6 \\
\hline $23 \mathrm{U}$ & 9370 & Vallecito Creek near mouth & Upper San Juan & Zn.wf & ROS & 52 & 35 & $<10$ & $<100$ & 7.48 & 14 \\
\hline
\end{tabular}


Table 8. Summary of selected trace element concentrations at sites with 10 or more samples in the Dolores, Upper San Juan, and Lower San Juan River Basins, southwestern Colorado, 1990-2005.-Continued

[Site ID, site identification number shown on figure 1; Database ID, data repository identification number; <, less than; concentrations are given in micrograms per liter; K-M flipped, Kaplan-Meier method modified for left-censored data used to compute summary statistics; ROS, the robust "regression on order statistics" method used to compute summary statistics; Estimate, summary statistics were reported as less than the maximum reporting limit; N, number of samples; NC, number of samples with concentrations reported as less than the reporting limit; Min, minimum value; Max, maximum value; Med, median; $\mathrm{C}_{85}$, 85th percentile concentration; Al.wf, dissolved aluminum; Al.wu, total recoverable aluminum; Fe.wf, dissolved iron; Fe.wu, total recoverable iron; Hg.wf, dissolved mercury; Hg.wu, total recoverable mercury; Pb.wf, dissolved lead; Pb.wu, total recoverable lead; Se.wf, dissolved selenium; Se.wu, total recoverable selenium; Ur.wf, dissolved uranium; Zn.wf, dissolved zinc; Zn.wu, total recoverable zinc; WWTP, wastewater treatment plant; values shown in blue indicate that chronic State water-quality standards were not met and values shown in red indicate that acute and chronic State water-quality standards were not met]

\begin{tabular}{|c|c|c|c|c|c|c|c|c|c|c|c|}
\hline $\begin{array}{l}\text { Site } \\
\text { ID }\end{array}$ & $\begin{array}{l}\text { Database } \\
\text { ID }\end{array}$ & Site name & $\begin{array}{c}\text { Subbasin } \\
\text { name }\end{array}$ & $\begin{array}{c}\text { Con- } \\
\text { stituent }\end{array}$ & Method & $\mathbf{N}$ & NC & Min & Max & Med & $\mathrm{C}_{85}$ \\
\hline \multicolumn{12}{|c|}{ Upper San Juan River Basin-Continued } \\
\hline $24 \mathrm{U}$ & 372236107344400 & Los Pinos River below Vallecito Reservoir near Bayfield & Upper San Juan & Zn.wf & ROS & 16 & 13 & $<0.5$ & 4.7 & 0.38 & 1.41 \\
\hline $25 \mathrm{U}$ & 9355 & Wallace Gulch at 502 Road north of Bayfield & Upper San Juan & Zn.wf & K-M flipped & 16 & 6 & $<10$ & 65 & 18.5 & 29 \\
\hline $30 \mathrm{U}$ & 9680 & La Plata at Hesperus & Middle San Juan & Zn.wf & ROS & 42 & 27 & $<1.8$ & 21 & 4.31 & 14 \\
\hline $31 \mathrm{U}$ & 9610 & Spring Creek near Breen & Middle San Juan & Zn.wf & K-M flipped & 12 & 1 & $<50$ & 60 & 23 & 29 \\
\hline $32 \mathrm{U}$ & 9720 & East Fork Mancos River at 44 Road & Mancos & Zn.wf & K-M flipped & 22 & 5 & $<10$ & 35 & 14.5 & 23 \\
\hline $34 \mathrm{U}$ & 9715 & Chicken Creek at Mancos & Mancos & Zn.wf & K-M flipped & 18 & 6 & $<10$ & 170 & 17 & 35 \\
\hline $01 \mathrm{~A}$ & A09 & North Fork above Cal. Gulch & Animas & Zn.wu & K-M flipped & 10 & 0 & 255 & 920 & 284 & 780 \\
\hline $02 \mathrm{~A}$ & A33 & Animas River at Eureka & Animas & Zn.wu & K-M flipped & 13 & 0 & 276 & 594 & 374 & 590 \\
\hline $06 \mathrm{~A}$ & AN68 & Animas River at USGS gaging station above 14th Street & Animas & Zn.wu & K-M flipped & 12 & 0 & 270 & 540 & 365 & 420 \\
\hline $07 \mathrm{~A}$ & A68 & Animas River at Silverton & Animas & Zn.wu & K-M flipped & 108 & 1 & $<3$ & 1,800 & 460 & 820 \\
\hline $10 \mathrm{~A}$ & $\mathrm{CC} 32$ & South Fork Cement Creek downstream from Velocity Lake & Animas & Zn.wu & K-M flipped & 13 & 0 & 158 & 367 & 190 & 266 \\
\hline $12 \mathrm{~A}$ & $\mathrm{CC} 23$ & Prospect Gulch upstream from Red Spring & Animas & Zn.wu & K-M flipped & 14 & 0 & 280 & 2,400 & 379 & 960 \\
\hline $15 \mathrm{~A}$ & $\mathrm{CC} 20$ & Porcupine Gulch upstream from mines & Animas & Zn.wu & K-M flipped & 12 & 0 & 430 & 11,300 & 1,311 & 8,770 \\
\hline $19 \mathrm{~A}$ & CEM48 & Cement Creek at USGS gaging station & Animas & Zn.wu & K-M flipped & 12 & 0 & 720 & 1,100 & 930 & 1,000 \\
\hline $20 \mathrm{~A}$ & M02 & Mineral Creek near headwaters & Animas & Zn.wu & K-M flipped & 10 & 0 & 11,000 & 310,000 & 77,500 & 230,000 \\
\hline $30 \mathrm{~A}$ & M27 & Mineral Creek above confluence with South Fork Mineral Creek & Animas & Zn.wu & K-M flipped & 15 & 0 & 110 & 920 & 340 & 860 \\
\hline $32 \mathrm{~A}$ & M34 & Mineral Creek at Silverton & Animas & Zn.wu & K-M flipped & 119 & 0 & 73 & 950 & 268 & 454 \\
\hline $34 \mathrm{~A}$ & AN72 & Animas River at USGS gaging station just above railroad bridge & Animas & Zn.wu & K-M flipped & 12 & 0 & 240 & 800 & 335 & 560 \\
\hline $35 \mathrm{~A}$ & A72 & Animas River downstream from Silverton & Animas & Zn.wu & K-M flipped & 65 & 0 & 176 & 930 & 423 & 722 \\
\hline $41 \mathrm{~A}$ & DRALP003 & Animas at Durango Mall & Animas & Zn.wu & K-M flipped & 86 & 5 & $<10$ & 780 & 60 & 108 \\
\hline $47 \mathrm{~A}$ & DRALPLC2 & Lightner Creek at mouth at Durango & Animas & Zn.wu & K-M flipped & 50 & 24 & $<10$ & 161 & 8 & 25 \\
\hline $48 \mathrm{~A}$ & DRALP001 & DRALP001 & Animas & Zn.wu & K-M flipped & 108 & 5 & $<10$ & 437 & 67 & 100 \\
\hline $49 \mathrm{~A}$ & DRALP002 & Animas River at Durango & Animas & Zn.wu & K-M flipped & 149 & 4 & $<10$ & 368 & 67 & 108 \\
\hline $50 \mathrm{~A}$ & DRALP209 & Animas River behind BMX track at Durango & Animas & Zn.wu & K-M flipped & 21 & 1 & $<10$ & 156 & 47 & 76 \\
\hline 07A & A68 & Animas River at Silverton & Animas & Se.wf & Estimat & 32 & 27 & $<0.5$ & $<6$ & $<6$ & $<6$ \\
\hline $09 \mathrm{~A}$ & $\mathrm{CC} 18$ & $\begin{array}{l}\text { North Fork Cement Creek upstream from Gold King mine, } \\
\text { \#7 level (AMLI mine \# 103) }\end{array}$ & Animas & Se.wf & Estimate & 91 & 89 & $<5$ & 14 & $<5$ & $<5$ \\
\hline $32 \mathrm{~A}$ & M34 & Mineral Creek at Silverton & Animas & Se.wf & Estimate & 30 & 26 & $<0.5$ & $<5$ & $<5$ & $<5$ \\
\hline $33 \mathrm{~A}$ & 09359020 & Animas River below Silverton & Animas & Se.wf & Estimate & 44 & 39 & $<0.2$ & $<2.4$ & $<2.4$ & $<2.4$ \\
\hline $36 \mathrm{~A}$ & 000082 & Animas River near Silverton & Animas & Se.wf & Estimate & 36 & 35 & $<1$ & 7 & $<5$ & $<5$ \\
\hline $39 \mathrm{~A}$ & 9445 & Cascade Creek at Highway 550 & Animas & Se.wf & Estimate & 16 & 14 & $<1$ & 1.4 & $<1$ & $<1$ \\
\hline $41 \mathrm{~A}$ & DRALP003 & Animas at Durango Mall & Animas & Se.wf & Estimate & 62 & 59 & $<0.5$ & 9 & $<2$ & $<2$ \\
\hline $43 \mathrm{~A}$ & 9440 & Falls Creek at 0.65 Road & Animas & Se.wf & Estimate & 13 & 13 & $<1$ & $<1$ & $<1$ & $<1$ \\
\hline
\end{tabular}


Table 8. Summary of selected trace element concentrations at sites with 10 or more samples in the Dolores, Upper San Juan, and Lower San Juan River Basins, southwestern Colorado, 1990-2005.-Continued

[Site ID, site identification number shown on figure 1; Database ID, data repository identification number; <, less than; concentrations are given in micrograms per liter; K-M flipped, Kaplan-Meier method modified for left-censored data used to compute summary statistics; ROS, the robust "regression on order statistics" method used to compute summary statistics; Estimate, summary statistics were reported as less than the maximum reporting limit; N, number of samples; NC, number of samples with concentrations reported as less than the reporting limit; Min, minimum value; Max, maximum value; Med, median; $\mathrm{C}_{85}$, 85th percentile concentration; Al.wf, dissolved aluminum; Al.wu, total recoverable aluminum; Fe.wf, dissolved iron; Fe.wu, total recoverable iron; Hg.wf, dissolved mercury; Hg.wu, total recoverable mercury; Pb.wf, dissolved lead; Pb.wu, total recoverable lead; Se.wf, dissolved selenium; Se.wu, total recoverable selenium; Ur.wf, dissolved uranium; Zn.wf, dissolved zinc; Zn.wu, total recoverable zinc; WWTP, wastewater treatment plant; values shown in blue indicate that chronic State water-quality standards were not met and values shown in red indicate that acute and chronic State water-quality standards were not met]

\begin{tabular}{|c|c|c|c|c|c|c|c|c|c|c|c|}
\hline $\begin{array}{l}\text { Site } \\
\text { ID }\end{array}$ & $\begin{array}{c}\text { Database } \\
\text { ID }\end{array}$ & Site name & $\begin{array}{c}\text { Subbasin } \\
\text { name }\end{array}$ & $\begin{array}{c}\text { Con- } \\
\text { stituent }\end{array}$ & Method & $\mathbf{N}$ & NC & Min & Max & Med & $\mathbf{C}_{85}$ \\
\hline \multicolumn{12}{|c|}{ Upper San Juan River Basin-Continued } \\
\hline $46 \mathrm{~A}$ & 9420 & Animas River at Durango & Animas & Se.wf & Estimate & 30 & 28 & $<1$ & 1.3 & $<1$ & $<1$ \\
\hline $47 \mathrm{~A}$ & DRALPLC2 & Lightner Creek at mouth at Durango & Animas & Se.wf & ROS & 48 & 37 & $<0.5$ & 28 & 0.39 & 2 \\
\hline $48 \mathrm{~A}$ & DRALP001 & DRALP001 & Animas & Se.wf & Estimate & 83 & 79 & $<0.5$ & 9 & $<2$ & $<2$ \\
\hline $49 \mathrm{~A}$ & DRALP002 & Animas River at Durango & Animas & Se.wf & Estimate & 124 & 109 & $<0.5$ & 8 & $<6$ & $<6$ \\
\hline $50 \mathrm{~A}$ & DRALP209 & Animas River behind BMX track at Durango & Animas & Se.wf & Estimate & 21 & 21 & $<1$ & $<1$ & $<1$ & $<1$ \\
\hline $53 \mathrm{~A}$ & 000138 & Florida River below Lemon Reservoir & Animas & Se.wf & Estimate & 10 & 10 & $<1$ & $<5$ & $<5$ & $<5$ \\
\hline $54 \mathrm{~A}$ & 9415 & Salt Creek at 309A Road & Animas & Se.wf & K-M flipped & 15 & 7 & $<1$ & 13 & 1 & 11 \\
\hline $57 \mathrm{~A}$ & 000066 & Animas River near Bondad & Animas & Se.wf & Estimate & 39 & 35 & $<0.4$ & 2 & $<1$ & $<1$ \\
\hline $01 \mathrm{U}$ & 9850 & Little Navajo River at Highway 84 & Upper San Juan & Se.wf & Estimate & 16 & 16 & $<1$ & $<1$ & $<1$ & $<1$ \\
\hline $03 \mathrm{U}$ & 9860 & Rio Blanco at Highway 84 & Upper San Juan & Se.wf & ROS & 17 & 13 & $<1$ & 2.3 & 0.43 & 1 \\
\hline $05 \mathrm{U}$ & 9165 & Sand Creek at mouth above East Fork San Juan River & Upper San Juan & Se.wf & Estimate & 12 & 12 & $<1$ & $<1$ & $<1$ & $<1$ \\
\hline $09 \mathrm{U}$ & 000137 & San Juan River above Pagosa Springs & Upper San Juan & Se.wf & Estimate & 24 & 24 & $<1$ & $<1$ & $<1$ & $<1$ \\
\hline $10 \mathrm{U}$ & 9120 & McCabe Creek above Pagosa Springs & Upper San Juan & Se.wf & K-M flipped & 17 & 6 & $<1$ & 2 & 1 & 2 \\
\hline $15 \mathrm{U}$ & 9290 & East Fork Piedra River below Piedra Falls & Piedra & Se.wf & Estimate & 12 & 12 & $<1$ & $<1$ & $<1$ & $<1$ \\
\hline $16 U$ & 9250 & Piedra River at Highway 160 & Piedra & Se.wf & Estimate & 53 & 53 & $<1$ & $<2$ & $<2$ & $<2$ \\
\hline $17 \mathrm{U}$ & 9245 & Stollsteimer Creek at Highway 151 & Piedra & Se.wf & K-M flipped & 18 & 6 & $<1$ & 2 & 1 & 1 \\
\hline $21 \mathrm{U}$ & 9380 & Los Pinos River above Vallecito Reservoir & Upper San Juan & Se.wf & Estimate & 52 & 52 & $<1$ & $<1$ & $<1$ & $<1$ \\
\hline $22 \mathrm{U}$ & 09352900 & Vallecito Creek near Bayfield & Upper San Juan & Se.wf & Estimate & 35 & 35 & $<1$ & $<2.4$ & $<2.4$ & $<2.4$ \\
\hline $23 \mathrm{U}$ & 9370 & Vallecito Creek near mouth & Upper San Juan & Se.wf & Estimate & 52 & 52 & $<1$ & $<1$ & $<1$ & $<1$ \\
\hline $25 \mathrm{U}$ & 9355 & Wallace Gulch at 502 Road north of Bayfield & Upper San Juan & Se.wf & Estimate & 16 & 16 & $<1$ & $<1$ & $<1$ & $<1$ \\
\hline $30 \mathrm{U}$ & 9680 & La Plata at Hesperus & Middle San Juan & Se.wf & Estimate & 42 & 42 & $<0.4$ & $<1$ & $<1$ & $<1$ \\
\hline $31 \mathrm{U}$ & 9610 & Spring Creek near Breen & Middle San Juan & Se.wf & Estimate & 12 & 12 & $<1$ & $<1$ & $<1$ & $<1$ \\
\hline $32 \mathrm{U}$ & 9720 & East Fork Mancos River at 44 Road & Mancos & Se.wf & Estimate & 22 & 22 & $<1$ & $<5$ & $<5$ & $<5$ \\
\hline $34 \mathrm{U}$ & 9715 & Chicken Creek at Mancos & Mancos & Se.wf & ROS & 18 & 13 & $<1$ & 2 & 0.64 & 1 \\
\hline 07A & A68 & Animas River at Silverton & Animas & Se.wu & ROS & 34 & 27 & $<0.5$ & 6 & 0.62 & 1.56 \\
\hline $32 \mathrm{~A}$ & M34 & Mineral Creek at Silverton & Animas & Se.wu & ROS & 31 & 24 & $<0.5$ & 5 & 0.52 & 1.05 \\
\hline $41 \mathrm{~A}$ & DRALP003 & Animas at Durango Mall & Animas & Se.wu & ROS & 88 & 50 & $<0.5$ & 28 & 0.95 & 4 \\
\hline $47 \mathrm{~A}$ & DRALPLC2 & Lightner Creek at mouth at Durango & Animas & Se.wu & K-M flipped & 50 & 21 & $<0.5$ & 32 & 1.8 & 12 \\
\hline $48 \mathrm{~A}$ & DRALP001 & DRALP001 & Animas & Se.wu & ROS & 108 & 73 & $<0.5$ & 34 & 0.85 & 4 \\
\hline $49 \mathrm{~A}$ & DRALP002 & Animas River at Durango & Animas & Se.wu & ROS & 150 & 99 & $<0.5$ & 28 & 0.79 & 4 \\
\hline $50 \mathrm{~A}$ & DRALP209 & Animas River behind BMX track at Durango & Animas & Se.wu & Estimate & 21 & 20 & $<1$ & $<1$ & $<1$ & $<1$ \\
\hline $41 \mathrm{~A}$ & DRALP003 & Animas at Durango Mall & Animas & Ur.wf & Estimate & 51 & 49 & $<3.4$ & $<3.74$ & $<3.74$ & $<3.74$ \\
\hline $46 \mathrm{~A}$ & 9420 & Animas River at Durango & Animas & Ur.wf & ROS & 12 & 6 & 1 & 8 & 0.79 & 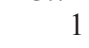 \\
\hline
\end{tabular}


Table 8. Summary of selected trace element concentrations at sites with 10 or more samples in the Dolores, Upper San Juan, and Lower San Juan River Basins, southwestern Colorado, 1990-2005.-Continued

[Site ID, site identification number shown on figure 1; Database ID, data repository identification number; <, less than; concentrations are given in micrograms per liter; K-M flipped, Kaplan-Meier method modified for left-censored data used to compute summary statistics; ROS, the robust "regression on order statistics" method used to compute summary statistics; Estimate, summary statistics were reported as less than the maximum reporting limit; N, number of samples; NC, number of samples with concentrations reported as less than the reporting limit; Min, minimum value; Max, maximum value; Med, median; $\mathrm{C}_{85}$, 85th percentile concentration; Al.wf, dissolved aluminum; Al.wu, total recoverable aluminum; Fe.wf, dissolved iron; Fe.wu, total recoverable iron; Hg.wf, dissolved mercury; Hg.wu, total recoverable mercury; Pb.wf, dissolved lead; Pb.wu, total recoverable lead; Se.wf, dissolved selenium; Se.wu, total recoverable selenium; Ur.wf, dissolved uranium; Zn.wf, dissolved zinc; Zn.wu, total recoverable zinc; WWTP, wastewater treatment plant; values shown in blue indicate that chronic State water-quality standards were not met and values shown in red indicate that acute and chronic State water-quality standards were not met]

\begin{tabular}{|c|c|c|c|c|c|c|c|c|c|c|c|}
\hline $\begin{array}{l}\text { Site } \\
\text { ID }\end{array}$ & $\begin{array}{l}\text { Database } \\
\text { ID }\end{array}$ & Site name & $\begin{array}{l}\text { Subbasin } \\
\text { name }\end{array}$ & $\begin{array}{c}\text { Con- } \\
\text { stituent }\end{array}$ & Method & $\mathbf{N}$ & NC & Min & Max & Med & $\mathbf{C}_{85}$ \\
\hline \multicolumn{12}{|c|}{ Upper San Juan River Basin_—Continued } \\
\hline $48 \mathrm{~A}$ & DRALP001 & DRALP001 & Animas & Ur.wf & ROS & 83 & 54 & 0.4 & 5.44 & 1.07 & 1.77 \\
\hline $49 \mathrm{~A}$ & DRALP002 & Animas River at Durango & Animas & Ur.wf & ROS & 118 & 72 & 0.48 & 63 & 1.08 & 2.18 \\
\hline $50 \mathrm{~A}$ & DRALP209 & Animas River behind BMX track at Durango & Animas & Ur.wf & K-M flipped & 28 & 0 & 0.4 & 1.6 & 1.06 & 1.3 \\
\hline $22 \mathrm{U}$ & 09352900 & Vallecito Creek near Bayfield & Upper San Juan & Ur.wf & K-M flipped & 22 & 10 & 0.31 & 0.74 & 0.42 & 0.49 \\
\hline $01 \mathrm{~L}$ & 9887 & McElmo Creek above Cortez Sanitation District, Southwest WWTP & McElmo & Al.wf & Estimate & 15 & 14 & $<30$ & $<500$ & $<500$ & $<500$ \\
\hline $05 \mathrm{~L}$ & 9871 & McElmo Creek above Trail Canyon at gage & McElmo & Al.wf & Estimate & 45 & 44 & $<30$ & $<2,500$ & $<2,500$ & $<2,500$ \\
\hline $\begin{array}{l}01 \mathrm{~L} \\
05 \mathrm{~L}\end{array}$ & $\begin{array}{l}9887 \\
9871\end{array}$ & $\begin{array}{l}\text { McElmo Creek above Cortez Sanitation District, Southwest WWTP } \\
\text { McElmo Creek above Trail Canyon at gage }\end{array}$ & $\begin{array}{l}\text { McElmo } \\
\text { McElmo }\end{array}$ & $\begin{array}{l}\text { Fe.wf } \\
\text { Fe.wf }\end{array}$ & $\begin{array}{l}\text { ROS } \\
\text { ROS }\end{array}$ & $\begin{array}{l}15 \\
40\end{array}$ & $\begin{array}{l}12 \\
34\end{array}$ & $\begin{array}{r}<100 \\
<10\end{array}$ & $\begin{array}{l}<100 \\
<500\end{array}$ & $\begin{array}{r}14 \\
5.99\end{array}$ & $\begin{array}{r}15 \\
13.2\end{array}$ \\
\hline $01 \mathrm{~L}$ & 9887 & McElmo Creek above Cortez Sanitation District, Southwest WWTP & McElmo & Fe.wu & K-M flipped & 15 & 1 & $<100$ & 13,000 & 890 & 3,700 \\
\hline $05 \mathrm{~L}$ & 9871 & McElmo Creek above Trail Canyon at gage & McElmo & Fe.wu & K-M flipped & 45 & 2 & $<100$ & 34,000 & 1,500 & 6,900 \\
\hline $01 \mathrm{~L}$ & 9887 & McElmo Creek above Cortez Sanitation District, Southwest WWTP & McElmo & Hg.wf & Estimate & 13 & 13 & $<0.1$ & $<0.2$ & $<0.2$ & $<0.2$ \\
\hline $05 \mathrm{~L}$ & 9871 & McElmo Creek above Trail Canyon at gage & McElmo & Hg.wf & Estimate & 28 & 28 & $<0.1$ & $<0.2$ & $<0.2$ & $<0.2$ \\
\hline $05 \mathrm{~L}$ & 9871 & McElmo Creek above Trail Canyon at gage & McElmo & Hg.wu & Estimate & 13 & 13 & $<0.2$ & $<0.2$ & $<0.2$ & $<0.2$ \\
\hline $01 \mathrm{~L}$ & 9887 & McElmo Creek above Cortez Sanitation District, Southwest WWTP & McElmo & Pb.wf & Estimate & 15 & 15 & $<0.1$ & $<5$ & $<5$ & $<5$ \\
\hline $05 \mathrm{~L}$ & 9871 & McElmo Creek above Trail Canyon at gage & McElmo & Pb.wf & Estimate & 45 & 44 & $<0.1$ & 11 & $<5$ & $<5$ \\
\hline $01 \mathrm{~L}$ & 9887 & $\begin{array}{l}\text { McElmo Creek above Cortez Sanitation District, } \\
\text { Southwest WWTP }\end{array}$ & McElmo & Zn.wf & ROS & 15 & 8 & $<10$ & $<200$ & 31 & 110 \\
\hline $05 \mathrm{~L}$ & 9871 & McElmo Creek above Trail Canyon at gage & McElmo & Zn.wf & ROS & 45 & 31 & $<10$ & $<500$ & 5.82 & 31 \\
\hline $01 \mathrm{~L}$ & 9887 & McElmo Creek above Cortez Sanitation District, Southwest WWTP & McElmo & Se.wf & K-M flipped & 15 & 3 & $<5$ & 5 & 2.4 & 4.1 \\
\hline $05 \mathrm{~L}$ & 9871 & McElmo Creek above Trail Canyon at gage & McElmo & Se.wf & K-M flipped & 45 & 11 & $<1$ & 8.4 & 2 & 5 \\
\hline $05 \mathrm{~L}$ & 9871 & McElmo Creek above Trail Canyon at gage & McElmo & Ur.wf & K-M flipped & 10 & 2 & 3 & 12 & 4.5 & 10 \\
\hline
\end{tabular}




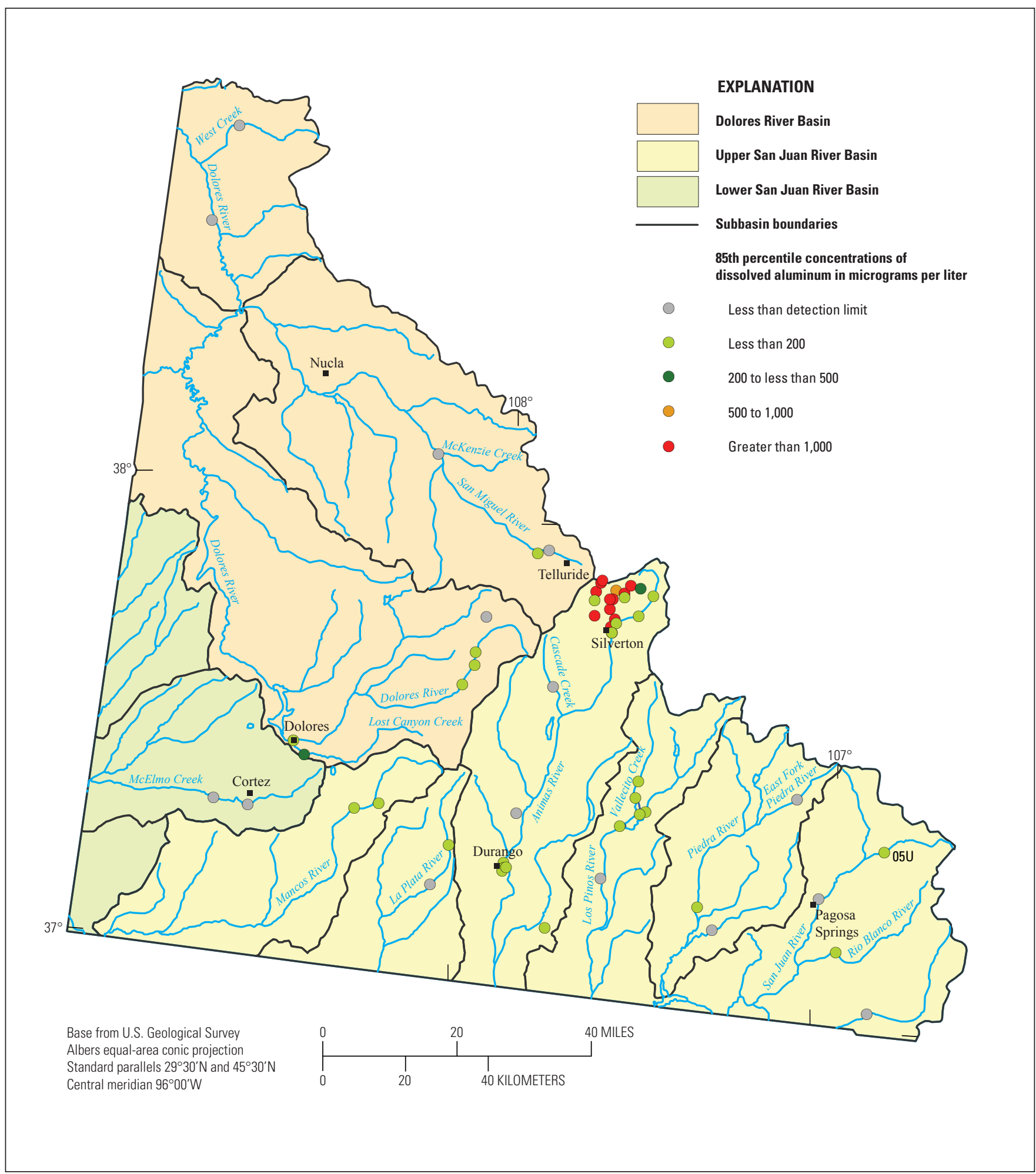

Figure 9. Map showing spatial distribution of 85th percentile concentrations of dissolved aluminum in the Dolores, Upper San Juan, and Lower San Juan River Basins, southwestern Colorado, 1990-2005. 
Table 9. Summary of trend analysis results for selected trace metals at sites in the Upper San Juan River Basin, southwestern Colorado, 1991-2004.

[Site ID, site identification number shown on figure 1; p-value, probability value; statistically significant trend at p-value less than or equal to 0.05 ; nt, no significant trend; $\mu \mathrm{g} / \mathrm{L}$, micrograms per liter; “--", insufficient data or available data did not meet the selection criteria; typical value is the median value for the trend analysis period in $\mu \mathrm{g} / \mathrm{L} ; \mathrm{yr}$, year]

\begin{tabular}{|c|c|c|c|c|c|c|c|c|c|c|c|c|c|c|c|c|}
\hline \multirow[b]{3}{*}{ Site ID } & \multirow[b]{3}{*}{ Site name } & \multicolumn{5}{|c|}{ Aluminum, dissolved } & \multicolumn{5}{|c|}{ Iron, dissolved } & \multicolumn{5}{|c|}{ Iron, total recoverable } \\
\hline & & \multirow[b]{2}{*}{$\begin{array}{l}\text { Typi- } \\
\text { cal } \\
\text { value }\end{array}$} & \multirow[b]{2}{*}{ Trend } & \multirow[b]{2}{*}{$\begin{array}{c}\text { p- } \\
\text { value }\end{array}$} & \multicolumn{2}{|c|}{ Trend slope } & \multirow[b]{2}{*}{$\begin{array}{l}\text { Typi- } \\
\text { cal } \\
\text { value }\end{array}$} & \multirow[b]{2}{*}{ Trend } & \multirow[b]{2}{*}{$\begin{array}{c}\text { p- } \\
\text { value }\end{array}$} & \multicolumn{2}{|c|}{ Trend slope } & \multirow[b]{2}{*}{$\begin{array}{l}\text { Typi- } \\
\text { cal } \\
\text { value }\end{array}$} & \multirow[b]{2}{*}{ Trend } & \multirow[b]{2}{*}{$\begin{array}{c}\text { p- } \\
\text { value }\end{array}$} & \multicolumn{2}{|c|}{ Trend slope } \\
\hline & & & & & $\begin{array}{l}\text { (per- } \\
\text { cent) }\end{array}$ & $\begin{array}{c}(\mu \mathrm{g} / \mathrm{L} \\
\text { per } \\
\mathrm{yr})\end{array}$ & & & & $\begin{array}{l}\text { (per- } \\
\text { cent) }\end{array}$ & $\begin{array}{c}(\mu g / L \\
\text { per } \\
y r)\end{array}$ & & & & $\begin{array}{l}\text { (per- } \\
\text { cent) }\end{array}$ & $\begin{array}{c}\text { ( } \mu \mathrm{g} / \mathrm{L} \\
\text { per } \\
\mathrm{yr})\end{array}$ \\
\hline 07A & $\begin{array}{l}\text { Animas River at } \\
\text { Silverton }\end{array}$ & $\mathrm{nt}$ & $\mathrm{nt}$ & $\mathrm{nt}$ & $\mathrm{nt}$ & $\mathrm{nt}$ & $\mathrm{nt}$ & $\mathrm{nt}$ & $\mathrm{nt}$ & $\mathrm{nt}$ & $\mathrm{nt}$ & $\mathrm{nt}$ & $\mathrm{nt}$ & $\mathrm{nt}$ & $\mathrm{nt}$ & $\mathrm{nt}$ \\
\hline $32 \mathrm{~A}$ & $\begin{array}{l}\text { Mineral Creek at } \\
\text { Silverton }\end{array}$ & -- & -- & -- & -- & -- & $\mathrm{nt}$ & $\mathrm{nt}$ & $\mathrm{nt}$ & $\mathrm{nt}$ & $\mathrm{nt}$ & -- & -- & -- & -- & -- \\
\hline $35 \mathrm{~A}$ & $\begin{array}{l}\text { Animas River down- } \\
\text { stream from } \\
\text { Silverton }\end{array}$ & $\mathrm{nt}$ & $\mathrm{nt}$ & $\mathrm{nt}$ & $\mathrm{nt}$ & $\mathrm{nt}$ & $\mathrm{nt}$ & $\mathrm{nt}$ & nt & $\mathrm{nt}$ & $\mathrm{nt}$ & -- & -- & -- & -- & -- \\
\hline \multirow[b]{3}{*}{ Site ID } & \multirow[b]{3}{*}{ Site name } & \multicolumn{5}{|c|}{ Lead, total recoverable } & \multicolumn{5}{|c|}{ Zinc, dissolved } & \multicolumn{5}{|c|}{ Zinc, total recoverable } \\
\hline & & \multirow[b]{2}{*}{$\begin{array}{l}\text { Typi- } \\
\text { cal } \\
\text { value }\end{array}$} & \multirow[b]{2}{*}{ Trend } & \multirow[b]{2}{*}{$\begin{array}{c}\mathbf{p -} \\
\text { value }\end{array}$} & \multicolumn{2}{|c|}{ Trend slope } & \multirow[b]{2}{*}{$\begin{array}{l}\text { Typi- } \\
\text { cal } \\
\text { value }\end{array}$} & \multirow[b]{2}{*}{ Trend } & \multirow[b]{2}{*}{$\begin{array}{c}\mathbf{p -} \\
\text { value }\end{array}$} & \multicolumn{2}{|c|}{ Trend slope } & \multirow[b]{2}{*}{$\begin{array}{l}\text { Typi- } \\
\text { cal } \\
\text { value }\end{array}$} & \multirow[b]{2}{*}{ Trend } & \multirow[b]{2}{*}{$\begin{array}{c}\text { p- } \\
\text { value }\end{array}$} & \multicolumn{2}{|c|}{ Trend slope } \\
\hline & & & & & $\begin{array}{l}\text { (per- } \\
\text { cent) }\end{array}$ & $\begin{array}{c}\text { ( } \mu \mathrm{g} / \mathrm{L} \\
\text { per yr) }\end{array}$ & & & & $\begin{array}{l}\text { (per- } \\
\text { cent) }\end{array}$ & $\begin{array}{c}\text { (pg/L } \\
\text { per } \\
\text { yr) }\end{array}$ & & & & $\begin{array}{l}\text { (per- } \\
\text { cent) }\end{array}$ & $\begin{array}{c}\text { ( } \mu g / L \\
\text { per } \\
\text { yr) }\end{array}$ \\
\hline $07 \mathrm{~A}$ & $\begin{array}{l}\text { Animas River at } \\
\text { Silverton }\end{array}$ & $\mathrm{nt}$ & $\mathrm{nt}$ & $\mathrm{nt}$ & $\mathrm{nt}$ & $\mathrm{nt}$ & $\mathrm{nt}$ & $\mathrm{nt}$ & $\mathrm{nt}$ & $\mathrm{nt}$ & $\mathrm{nt}$ & $\mathrm{nt}$ & $\mathrm{nt}$ & $\mathrm{nt}$ & $\mathrm{nt}$ & $\mathrm{nt}$ \\
\hline $32 \mathrm{~A}$ & $\begin{array}{l}\text { Mineral Creek at } \\
\text { Silverton }\end{array}$ & 7.0 & down & 0.034 & -9.1 & -0.6 & 330 & down & 0.007 & -5.3 & -17.4 & 350 & down & 0.013 & -4.2 & -14.7 \\
\hline $35 \mathrm{~A}$ & $\begin{array}{l}\text { Animas River down- } \\
\text { stream from } \\
\text { Silverton }\end{array}$ & -- & -- & -- & -- & -- & $\mathrm{nt}$ & $\mathrm{nt}$ & $\mathrm{nt}$ & $\mathrm{nt}$ & $\mathrm{nt}$ & $\mathrm{nt}$ & $\mathrm{nt}$ & $\mathrm{nt}$ & $\mathrm{nt}$ & $\mathrm{nt}$ \\
\hline
\end{tabular}

${ }^{1}$ Dissolved zinc at site 35A was the only site and parameter combination that had enough data to analyze using four seasons. 
aquatic-life criteria were listed (Colorado Department of Public Health and Environment, 2010a). In addition to the chronic aquatic-life criterion, a domestic water-supply criterion of $300 \mu \mathrm{g} / \mathrm{L}$ was applied to waters used for water supply (Colorado Department of Public Health and Environment, 2010a).

Dolores River Basin. - Total recoverable iron concentrations were analyzed at 17 sites. Median total recoverable iron concentrations ranged from 4.8 to $450 \mu \mathrm{g} / \mathrm{L}$ (table 8 and fig. 10) and were less than $300 \mu \mathrm{g} / \mathrm{L}$ (domestic water-supply criterion) at 16 of the 17 sites analyzed (table 8). Based on available data, all sites in the Dolores River Basin met the State aquatic-life criterion for total recoverable iron. Adequate data were not available to perform trend analyses.

Upper San Juan River Basin.-Total recoverable iron concentrations were analyzed at 35 sites. Median concentrations ranged from 1.6 to $225,000 \mu \mathrm{g} / \mathrm{L}$ (table 8). Median total recoverable iron concentrations equal to or greater than $1,000 \mu \mathrm{g} / \mathrm{L}$ occurred at 10 sites in the Upper SJRB (fig. 10). The highest median total recoverable iron concentrations (greater than $1,000 \mu \mathrm{g} / \mathrm{L}$ ) generally occurred in the Cement and Mineral Creek basins and in the Animas River near Silverton (fig. 10). Total recoverable iron concentrations at these sites exceeded the general State water-quality criterion of $1,000 \mu \mathrm{g} / \mathrm{L}$ but may not have exceeded site-specific monthly criteria. Monthly median total recoverable iron concentrations were not calculated. One additional site in the Upper SJRB, McCabe Creek above Pagosa Springs (site 10U), had a median total recoverable iron concentration of $1,000 \mu \mathrm{g} / \mathrm{L}$ (fig. 10). The remaining sites in the Upper SJRB had median total recoverable iron concentrations less than $800 \mu \mathrm{g} / \mathrm{L}$; and most sites had median concentrations less than $450 \mu \mathrm{g} / \mathrm{L}$.

Total recoverable iron concentrations in the upper Animas River were affected by inflow from Cement and Mineral Creeks. Median total recoverable iron concentrations were less than $300 \mu \mathrm{g} / \mathrm{L}$ in the Animas River upstream from the confluences with Cement and Mineral Creeks. Immediately downstream from the confluences with Cement and Mineral Creeks, the median total recoverable iron concentration in the Animas River was $2,590 \mu \mathrm{g} / \mathrm{L}$ at the Animas River downstream from Silverton (site 35A). Whereas, further downstream, median total recoverable iron concentrations in the Animas River decreased to less than $300 \mu \mathrm{g} / \mathrm{L}$ in the vicinity of Durango.

Median total recoverable iron concentrations at Animas River downstream from Silverton (site 35A) and Mineral Creek at Silverton (site 32A) were higher during the winter than during the summer; whereas, upstream at Animas River at Silverton (site 07A) and downstream at the Animas River at Durango (site 46A) median total recoverable iron concentrations were similar during the winter and summer (fig. 1). One site on the Animas River was analyzed for trends in total recoverable iron. No significant trends in total recoverable iron concentration data (1991-2004) occurred at the site (table 9).

Lower San Juan River Basin.-Total recoverable iron concentrations were analyzed at McElmo Creek above
Cortez Sanitation District, Southwest WWTP and McElmo Creek above Trail Canyon at gage. Median total recoverable iron concentrations in McElmo Creek increased by about 69 percent between McElmo Creek above Cortez Sanitation District, Southwest WWTP and McElmo Creek above Trail Canyon going from 890 to $1,500 \mu \mathrm{g} / \mathrm{L}$ (table 8 ). This increase in total recoverable iron concentrations may be because of irrigation return flows and inflow from tributaries between the two sites (Richards and Leib, 2011). Total recoverable iron concentrations (at these two sites) in samples from McElmo Creek tended to be higher during the summer (April-October) than during the winter (November-March). Adequate data were not available to perform trend analysis for total recoverable iron at either site.

\section{Mercury}

One or more samples were collected and analyzed for total (unfiltered recoverable) mercury at 156 sites. Concentrations of total mercury measured in samples from these sites ranged from less than 0.005 to $12 \mu \mathrm{g} / \mathrm{L}$. Reporting limits for mercury typically ranged from 0.005 to $1 \mu \mathrm{g} / \mathrm{L}$. At least 1 measured concentration of total mercury exceeded the chronic aquatic-life criterion of $0.01 \mu \mathrm{g} / \mathrm{L}$ for 32 of the 156 sites sampled (Colorado Department of Public Health and Environment, 2010b). Determining the actual distribution of mercury in surface water throughout the study area was not possible because reporting limits often varied at sites and were usually higher than the aquatic-life criterion.

The most common human exposure to mercury is through consumption of fish or shellfish that are contaminated with methyl mercury (U.S. Environmental Protection Agency, 2011). Elemental mercury can be converted to methyl mercury by microorganisms and then accumulate in fish and shellfish through the aquatic food chain (U.S. Environmental Protection Agency, 2011). A 1990 health risk assessment conducted by the CDPHE indicated that methyl mercury levels of 0.2 part per million (ppm) (one-fifth of the U.S. Food and Drug Administration's (FDA) action level of $1 \mathrm{ppm}$ ) in sport-caught fish may pose a health risk to sensitive subpopulations (Colorado Department of Public Health and Environment, 2010b).

Atmospheric deposition is the primary pathway for mercury to enter aquatic ecosystems (Krabbenhoft and Rickert, 1995); however, point sources may produce higher concentrations in localized areas. The U.S. Environmental Protection Agency (2011) reports that the largest anthropogenic source of airborne mercury in the United States is emissions from coal-burning power plants. In southwestern Colorado, the highest mercury concentrations were measured in the lower Animas River Basin near Durango, in the upper Animas River Basin in the vicinity of Silverton, and in the lower San Miguel River Basin downstream from Nucla. The presence of higher concentrations of mercury in these areas could be because of natural sources of mercury in rocks, 


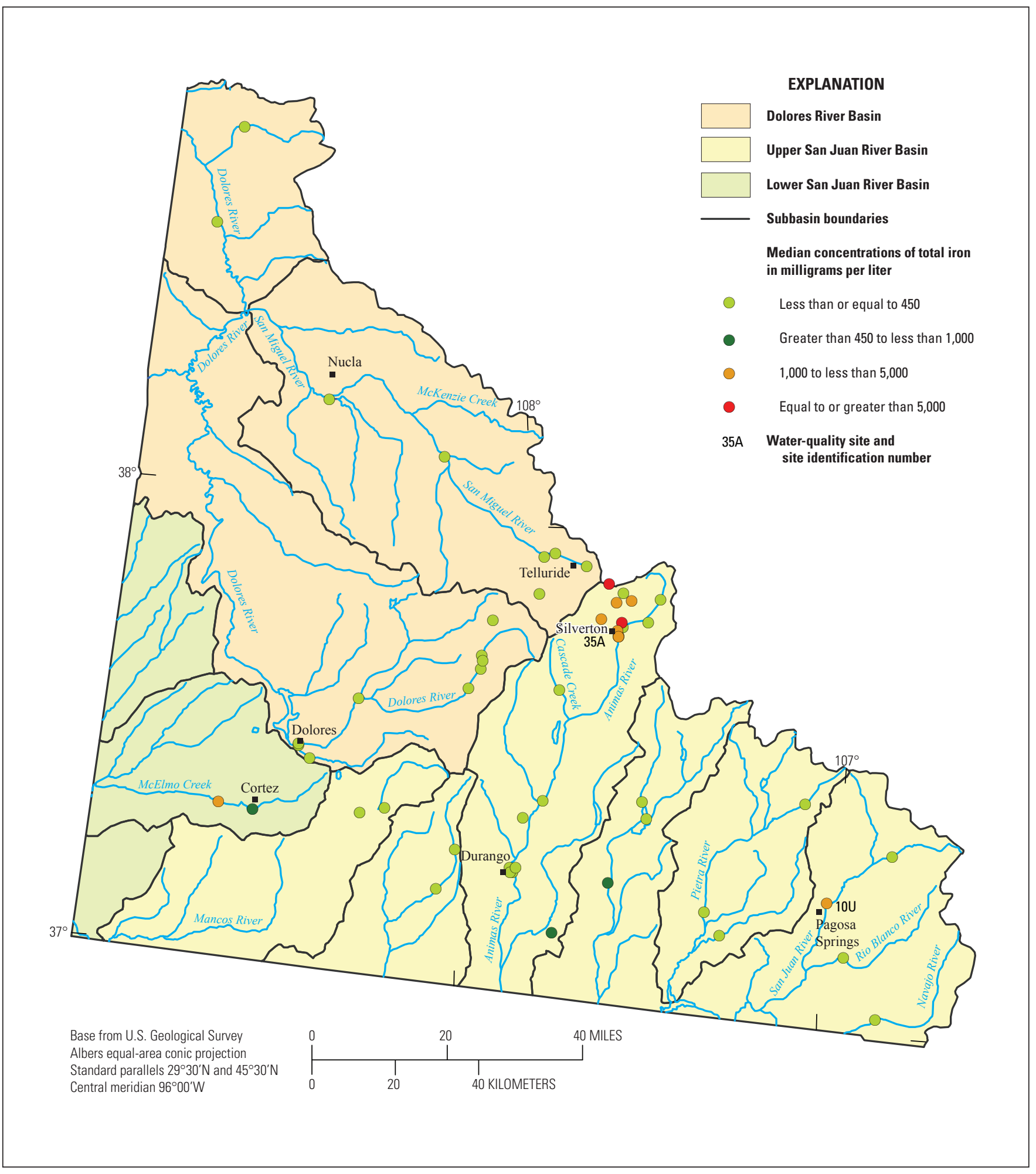

Figure 10. Map showing spatial distribution of median total recoverable iron concentrations in the Dolores, Upper San Juan, and Lower San Juan River Basins, southwestern Colorado, 1990-2005. 
waste products of historical smelting processes used to extract metals, and deposition of mercury from regional or local coal combustion and forest fires.

Only 31 of the 156 sites sampled for total mercury had adequate data to calculate summary statistics (table 8). Total mercury was not detected above the individual reporting limits in most samples; 30 of the 31 sites with 10 or more samples had more than 80 percent censored data. Consequently, median total mercury concentrations were all less than the reporting limits and could not be compared to State standards and trend analyses could not be performed.

\section{Lead}

Many of the dissolved lead concentrations in samples were censored. Reporting limits for lead varied from 1 to $50 \mu \mathrm{g} / \mathrm{L}$ and were often greater than the calculated chronic criteria. As a result, sample data from some sites could not be compared to criteria. For most stream segments in the study area, the acute and chronic aquatic-life criteria for dissolved lead were based on hardness; however, some segments had fixed site-specific chronic aquatic-life criteria for total recoverable lead, typically equal to $100 \mu \mathrm{g} / \mathrm{L}$ (Colorado Department of Public Health and Environment, 2010a). Hardness-based acute criteria for dissolved lead ranged from about 9 to $281 \mu \mathrm{g} / \mathrm{L}$. Chronic criteria ranged from about 0.3 to $11 \mu \mathrm{g} / \mathrm{L}$. Adequate data were not available to analyze trends in dissolved or total-recoverable lead concentrations primarily because of the large amount of censored data.

Dolores River Basin.-Dissolved lead concentrations were analyzed at 17 sites (table 8). Only two sites had 85 th percentile concentrations greater than the individual reporting limits for dissolved lead. These sites, Silver Creek at Highway 145 (site 04D) and San Miguel River at Society Turn (site 25D), both had 85th percentile concentrations of dissolved lead equal to $1 \mu \mathrm{g} / \mathrm{L}$ (table 8).

Upper San Juan River Basin.- Dissolved lead concentrations were analyzed at 48 sites. Only 15 sites had 85th percentile concentrations greater than the individual reporting limits. The 85th percentile concentrations for dissolved lead ranged from less than 1 to $250 \mu \mathrm{g} / \mathrm{L}$ (table 8 and fig. 11). The highest dissolved lead concentrations generally occurred in the Mineral and Cement Creek basins. State criteria in these areas were based on total recoverable lead concentrations. Adequate data were not available to analyze trends in dissolved lead concentrations in the Upper SJRB.

Total-recoverable lead data (sites with 10 or more samples) were available for 14 sites in the Animas River Basin. For sites with less than 80 percent censored data, median concentrations of total recoverable lead ranged from 0.007 to $35 \mu \mathrm{g} / \mathrm{L}$. Based on available data, median totalrecoverable lead concentrations in the Animas River Basin did not exceed State standards. Two sites in the Upper SJRB had adequate total-recoverable lead data to analyze for trends. One site, Mineral Creek at Silverton (site 32A), showed a significant downward trend in total-recoverable lead concentrations of 9.1 percent (table 9). The typical total-recoverable lead concentration at this site (1991-2004) was $7 \mu \mathrm{g} / \mathrm{L}$. The remaining site, Animas River at Silverton (site 07A), showed no trend (table 9).

Lower San Juan River Basin.-Dissolved lead concentrations were analyzed at McElmo Creek above Cortez Sanitation District, Southwest WWTP (site 01L) and McElmo Creek above Trail Canyon (site 05L). One-hundred percent of the dissolved lead concentrations in samples from McElmo Creek above Cortez Sanitation District, Southwest WWTP were censored values; and 97 percent of the dissolved lead concentrations in samples from McElmo Creek above Trail Canyon were censored values. Adequate data were not available to analyze trends in dissolved lead concentrations in the Lower SJRB.

\section{Zinc}

The 85th percentile concentrations for dissolved zinc ranged from less than 2 to $180,000 \mu \mathrm{g} / \mathrm{L}$ (table 8 ). Throughout much of the study area, 85th percentile concentrations of dissolved zinc were less than $200 \mu \mathrm{g} / \mathrm{L}$ (fig. 12). Some sites, particularly those located in the upper Animas River Basin, had higher concentrations. Colorado State aquatic life acute and chronic standards for dissolved zinc were, for the most part, hardness based. Using available data, hardness-based acute criteria for dissolved zinc ranged from 32 to $564 \mu \mathrm{g} / \mathrm{L}$. Chronic criteria ranged from 24 to $428 \mu \mathrm{g} / \mathrm{L}$. For several segments in the upper Animas River Basin, the Commission established specific monthly acute and chronic criteria for dissolved zinc (Colorado Department of Public Health and Environment, 2010a); however, monthly 85th percentile dissolved zinc concentrations were not calculated for this report.

Dolores River Basin.-Dissolved zinc concentrations were analyzed at 17 sites. The 85 th percentile concentrations of dissolved zinc ranged from less than 10 to $1,300 \mu \mathrm{g} / \mathrm{L}$ (table 8). Four sites had dissolved zinc concentrations that exceeded acute and chronic hardness-based criteria. Two of these sites were located along the upper San Miguel River near Telluride where 85th percentile concentrations of dissolved zinc were between 200 and $500 \mu \mathrm{g} / \mathrm{L}$ (fig. 12). The other two sites [Salt Creek at Highway 141 (site 35D) and Silver Creek at Highway 145 (site 04D)] that exceeded hardness-based criteria had 85th percentile concentrations of dissolved zinc greater than $500 \mu \mathrm{g} / \mathrm{L}$ (fig. 12). Most sites in the Dolores River Basin showed no statistically significant difference between winter and summer concentrations of dissolved zinc or lacked a sufficient distribution of data to determine if seasonal differences in concentrations existed. Adequate data were not available to analyze trends in dissolved zinc concentrations.

Upper San Juan River Basin.—Dissolved zinc concentrations were analyzed at 54 sites. The 85 th percentile dissolved zinc concentrations ranged from less than 2 to 


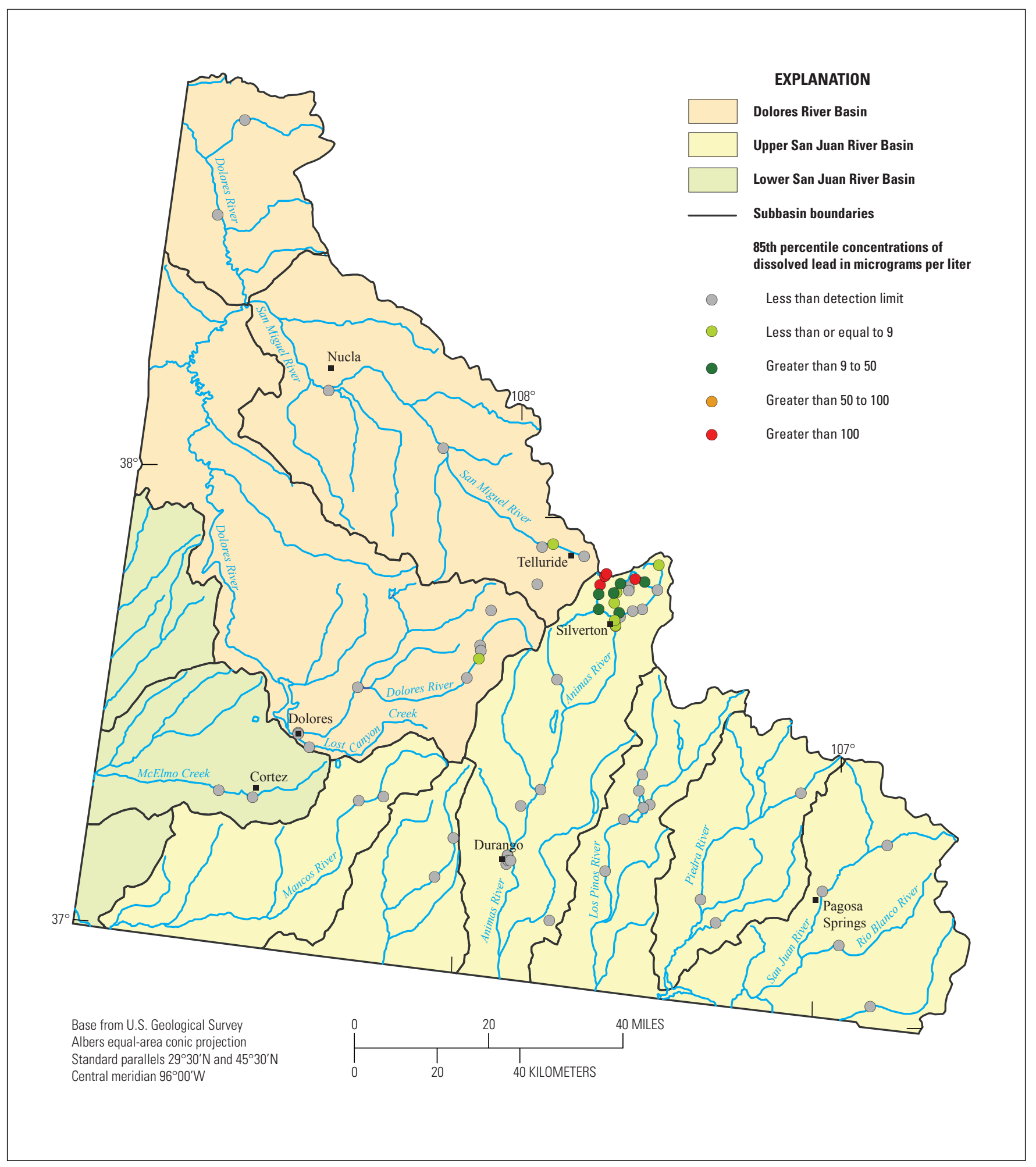

Figure 11. Map showing spatial distribution of 85th percentile concentrations of dissolved lead in the Dolores, Upper San Juan, and Lower San Juan River Basins, southwestern Colorado, 1990-2005. 


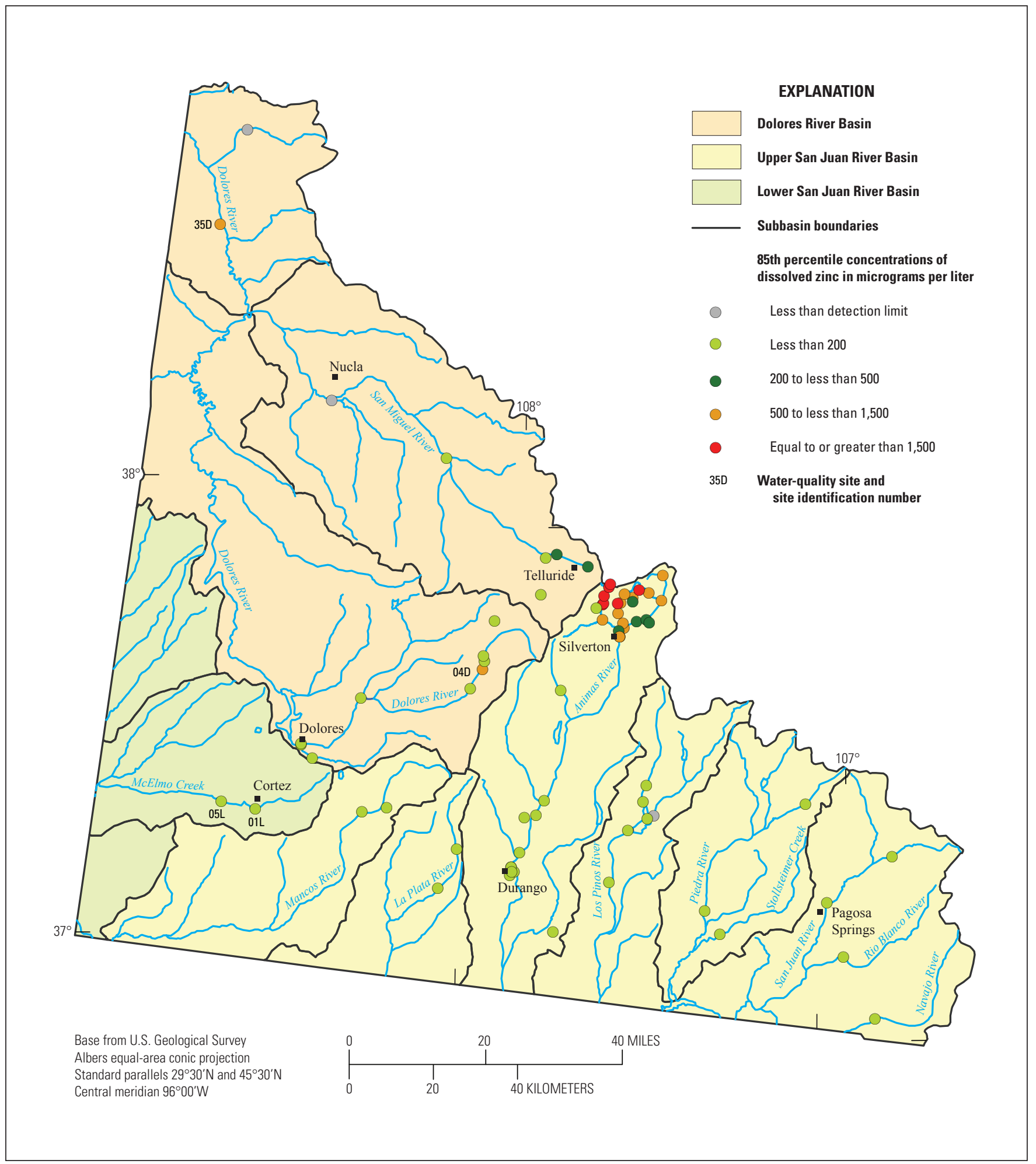

Figure 12. Map showing spatial distribution of 85th percentile concentrations of dissolved zinc in the Dolores, Upper San Juan, and Lower San Juan River Basins, southwestern Colorado, 1990-2005. 
$180,000 \mu \mathrm{g} / \mathrm{L}$ (table 8). Many sites in the upper Animas River Basin had 85th percentile dissolved zinc concentrations greater than $500 \mu \mathrm{g} / \mathrm{L}$ (table 8). Twenty-four sites had 85 th percentile concentrations that exceeded acute and chronic hardness-based standards. Sites with concentrations of dissolved zinc that exceeded acute and chronic hardness-based standards may not have exceeded segment-specific monthly standards. Monthly standards were not calculated. For the most part, dissolved zinc concentrations were higher in samples collected during the winter than during the summer in the Upper SJRB.

Data at two sites on the Animas River and one site on Mineral Creek were analyzed for trends in filtered and unfiltered zinc. Downward trends in zinc concentrations, unfiltered and filtered, occurred at the Mineral Creek at Silverton (32A) site (fig. 1 and table 9). No significant trends in filtered or unfiltered zinc concentration data (1991-2004) occurred at Animas River at Silverton (site 07A) or Animas River downstream from Silverton (site 35A).

Lower San Juan River Basin.-Dissolved zinc concentrations were analyzed at two sites along McElmo Creek (table 8). The 85th percentile concentrations of $110 \mu \mathrm{g} / \mathrm{L}$ at McElmo Creek above Cortez Sanitation District, Southwest WWTP (site 01L) and $31 \mu \mathrm{g} / \mathrm{L}$ at McElmo Creek above Trail Canyon at gage (site 05L) were well below the State hardnessbased criteria. The cause of the decrease in dissolved zinc concentrations between the two sites is not known. Seasonal and trend analysis could not be performed because more than 50 percent of the data at each site were censored and reporting limits were variable.

\section{Selenium}

In total, more than 2,000 samples were analyzed for dissolved selenium, and more than 800 samples were analyzed for total selenium throughout the study area. Dissolved selenium concentrations in samples ranged from less than 0.2 to $170 \mu \mathrm{g} / \mathrm{L}$. Total selenium concentrations ranged from less than 0.4 to $60.3 \mu \mathrm{g} / \mathrm{L}$. The discussion in this section of the report focuses on dissolved selenium concentrations at sites where 10 or more samples were collected. In the study area, the State chronic water-quality standard for selenium was $4.6 \mu \mathrm{g} / \mathrm{L}$; and the acute standard was $18.4 \mu \mathrm{g} / \mathrm{L}$ (Colorado Department of Public Health and Environment, 2010a). Reporting limits for dissolved selenium at some sites were higher than the State chronic and(or) acute selenium standards; as a result, it was not possible to determine if concentrations of selenium exceeded standards at these sites.

Dolores River Basin. - Adequate data were available to calculate summary statistics for dissolved selenium concentrations at 16 sites in the Dolores River Basin. Only five sites had less than 80 percent censored data, 85th percentile dissolved selenium concentrations for these sites ranged from 1.2 to $23 \mu \mathrm{g} / \mathrm{L}$ (table 8). One site in the Dolores River Basin, Salt Creek at Highway 141 (site 35D), had an 85th percentile concentration of dissolved selenium equal to $23 \mu \mathrm{g} / \mathrm{L}$ which exceeded the State chronic $(4.6 \mu \mathrm{g} / \mathrm{L})$ and acute standards $(18.4 \mu \mathrm{g} / \mathrm{L})$. Most sites had 85 th percentile concentrations equal to or less than $3 \mu \mathrm{g} / \mathrm{L}$. A dissolved selenium concentration of $62.1 \mu \mathrm{g} / \mathrm{L}$ was measured in 1 of the 10 samples collected at the Dolores River at Dolores (site 11D). Concentrations in the remaining 9 samples, collected at this site, were reported as less than $40 \mu \mathrm{g} / \mathrm{L}$; as a result, the 85 th percentile concentration was reported as less than $40 \mu \mathrm{g} / \mathrm{L}$. It is not known if dissolved selenium concentrations exceeded State standards at this site. Adequate data were not available to analyze for trends in dissolved selenium concentrations.

Upper San Juan River Basin. - Adequate data were available to calculate summary statistics for dissolved selenium concentrations at 32 sites in the Upper SJRB. Twenty-six of the sites had more than 80 percent censored data. The 85th percentile dissolved selenium concentrations ranged from less than 1 to $11 \mu \mathrm{g} / \mathrm{L}$ (table 8). Most sites had 85th percentile concentrations less than $3 \mu \mathrm{g} / \mathrm{L}$. Only one site, Salt Creek at 309A Road (site 54A), had an 85th percentile concentration of dissolved selenium that exceeded the State chronic standard (table 8). Dissolved selenium concentrations greater than the acute water-quality standard $(18.4 \mu \mathrm{g} / \mathrm{L})$ occurred in some samples along Navajo Wash in the southwestern corner of the Upper SJRB (fig. 1). Summary statistics were not calculated for these sites along Navajo Wash because fewer than 10 samples were collected at each site. Adequate data were not available to analyze for trends in dissolved selenium concentrations.

Lower San Juan River Basin. —Adequate data were available to calculate summary statistics for dissolved selenium concentrations at McElmo Creek above Cortez Sanitation District, Southwest WWTP and McElmo Creek above Trail Canyon (table 8). The 85th percentile dissolved selenium concentration at McElmo Creek above Cortez Sanitation District, Southwest WWTP (site 01L) was equal to $4.1 \mu \mathrm{g} / \mathrm{L}$. At McElmo Creek above Trail Canyon (site 05L), the 85th percentile dissolved selenium concentration was equal to $5 \mu \mathrm{g} / \mathrm{L}$ and exceeded the State chronic standard (fig. 13). Dissolved selenium concentrations greater than the acute water-quality standard $(18.4 \mu \mathrm{g} / \mathrm{L})$ occurred in some samples collected from Mud Creek sites near Cortez; however, summary statistics were not calculated because fewer than 10 samples were analyzed for dissolved selenium at the sites. Adequate data were not available to analyze for trends in dissolved selenium concentrations.

\section{Nutrients}

The occurrence and distribution of total ammonia, nitrate and nitrite, and total phosphorus are discussed in the Ammonia, Nitrate and Nitrite, and Phosphorus sections of the report. Median and 85th percentile concentrations were calculated for sites with 10 or more samples; and these concentrations were 
compared to applicable State aquatic-life water-quality criteria to provide an overview of existing water quality. Concentrations of total ammonia, nitrate, nitrite, and total phosphorus generally were low throughout the study area.

\section{Ammonia}

Only four sites had adequate data to compute summary statistics for total ammonia [sum of un-ionized ammonia $\left(\mathrm{NH}_{3}\right)$ and ammonium $\left(\mathrm{NH}_{4}^{+}\right)$]; all concentrations were less than $0.05 \mathrm{mg} / \mathrm{L}$ (table 10). The Commission established table-value standards for total ammonia based on $\mathrm{pH}$ and water temperature (Colorado Department of Public Health and Environment, 2010a). The mean $\mathrm{pH}$ and mean water temperature values shown in table 2 were used to calculate the table-value standards for each site for comparison purposes. The 85th percentile concentrations of total ammonia were less than the calculated chronic and acute table-value standards for total ammonia at the sites analyzed. Adequate data were not available to analyze temporal trends in total ammonia concentrations.

\section{Nitrate and Nitrite}

Nitrate and nitrite concentrations generally were low compared to water-quality standards. Concentrations of dissolved nitrate in samples ranged from less than 0.01 to $7.5 \mathrm{mg} / \mathrm{L}$. Dissolved nitrite concentrations ranged from less than 0.001 to $0.16 \mathrm{mg} / \mathrm{L}$, but most dissolved nitrite concentrations were less than $0.01 \mathrm{mg} / \mathrm{L}$. More samples were analyzed for nitrate plus nitrite than nitrate or nitrite alone. Nitrate plus nitrite concentrations (total as nitrogen) ranged from less than 0.05 to $15 \mathrm{mg} / \mathrm{L}$ in samples; and 87 percent of samples analyzed had concentrations less than or equal to $0.5 \mathrm{mg} / \mathrm{L}$. Nitrate plus nitrite concentrations generally were higher in samples collected during the winter period than in samples collected during the summer period.

The distribution of nitrate plus nitrite concentrations likely represents the distribution of nitrate concentrations because nitrite concentrations likely contribute a small part of the overall nitrate plus nitrite concentration. For most stream segments in the study area, the State stream waterquality standard for nitrate is $10 \mathrm{mg} / \mathrm{L}$ (Colorado Department of Public Health and Environment, 2010a). The national primary drinking-water standard for nitrate also is $10 \mathrm{mg} / \mathrm{L}$ (U.S. Environmental Protection Agency, 2010a). The Colorado stream water-quality standard for nitrite is $0.05 \mathrm{mg} / \mathrm{L}$ for most stream segments in the study area (Colorado Department of Public Health and Environment, 2010a); whereas, the national primary drinking-water standard for nitrite is $1 \mathrm{mg} / \mathrm{L}$

(U.S. Environmental Protection Agency, 2010a).

Dolores River Basin.-Adequate data were available at 21 sites to calculate summary statistics for nitrate plus nitrite concentrations. The 85 th percentile nitrate plus nitrite concentrations ranged from less than 0.05 to $0.78 \mathrm{mg} / \mathrm{L}$ (table 10 ).
Based on available data, sites in the Dolores River Basin met State water-quality standards for nitrate concentrations.

Upper San Juan River Basin.-Adequate data were available at 35 sites to calculate summary statistics for nitrate plus nitrite concentrations. The 85 th percentile nitrate plus nitrite concentrations ranged from 0.06 to $2.4 \mathrm{mg} / \mathrm{L}$ (table 10). Only 4 of the 35 sites analyzed had 85 th percentile concentrations of nitrate plus nitrite greater than $1 \mathrm{mg} / \mathrm{L}$ (fig. 14). These sites were located in the vicinity of Durango mostly on the Animas River. Based on available data, sites in the Upper SJRB met State water-quality standards for nitrate concentrations. The Vallecito Creek near Bayfield (22U) site was the only site in the Upper SJRB that had sufficient data to perform trend analyses for nitrate plus nitrite concentrations. No significant trends in nitrate plus nitrite concentrations occurred at the site (table 7).

Lower San Juan River Basin.-In the Lower SJRB, only the McElmo Creek above Cortez Sanitation District, Southwest WWTP and McElmo Creek above Trail Canyon at gage sites had adequate data to calculate summary statistics for nitrate plus nitrite concentrations. The 85th percentile nitrate plus nitrite concentration at McElmo Creek above Cortez Sanitation District, Southwest WWTP (site 01L) was equal to $1 \mathrm{mg} / \mathrm{L}$ (table 10 and fig. 14). Downstream, at McElmo Creek above Trail Canyon at gage (site 05L), the 85 th percentile nitrate plus nitrite concentration was equal to $2.7 \mathrm{mg} / \mathrm{L}$ (table 10 and fig. 14). Irrigation return flow likely contributes to the higher concentrations of nitrate plus nitrite at the downstream site. Concentrations of nitrate plus nitrate in the Lower SJRB were significantly ( $\mathrm{p}$-value $<0.01$ ) higher in samples collected during the winter than in samples collected during the summer. During the winter months, inflow from groundwater which may have higher concentrations of nitrate plus nitrite is likely a larger part of the overall streamflow in the streams. Further study, however, would be required to understand the sources and(or) processes that are affecting nitrate plus nitrite concentrations in water in the Lower SJRB. Adequate data were not available to analyze for temporal trends in nitrate plus nitrite concentrations.

\section{Phosphorus}

Total phosphorus concentrations ranged from less than 0.002 to $11 \mathrm{mg} / \mathrm{L}$, though most samples had total phosphorus concentrations less than $0.1 \mathrm{mg} / \mathrm{L}$. Reporting limits for total phosphorus samples used in this report ranged from 0.002 to $0.1 \mathrm{mg} / \mathrm{L}$. No water-quality criteria for total phosphorus were listed for streams in southwestern Colorado (Colorado Department of Public Health and Environment, 2010a). In the study area, 85 th percentile total phosphorus concentrations ranged from 0.009 to $1.1 \mathrm{mg} / \mathrm{L}$.

Dolores River Basin.-Adequate data were available for 24 sites to calculate summary statistics for total phosphorus concentrations. The 85 th percentile total phosphorus concentrations ranged from less than 0.05 to $1.1 \mathrm{mg} / \mathrm{L}$ (table 10 ). 


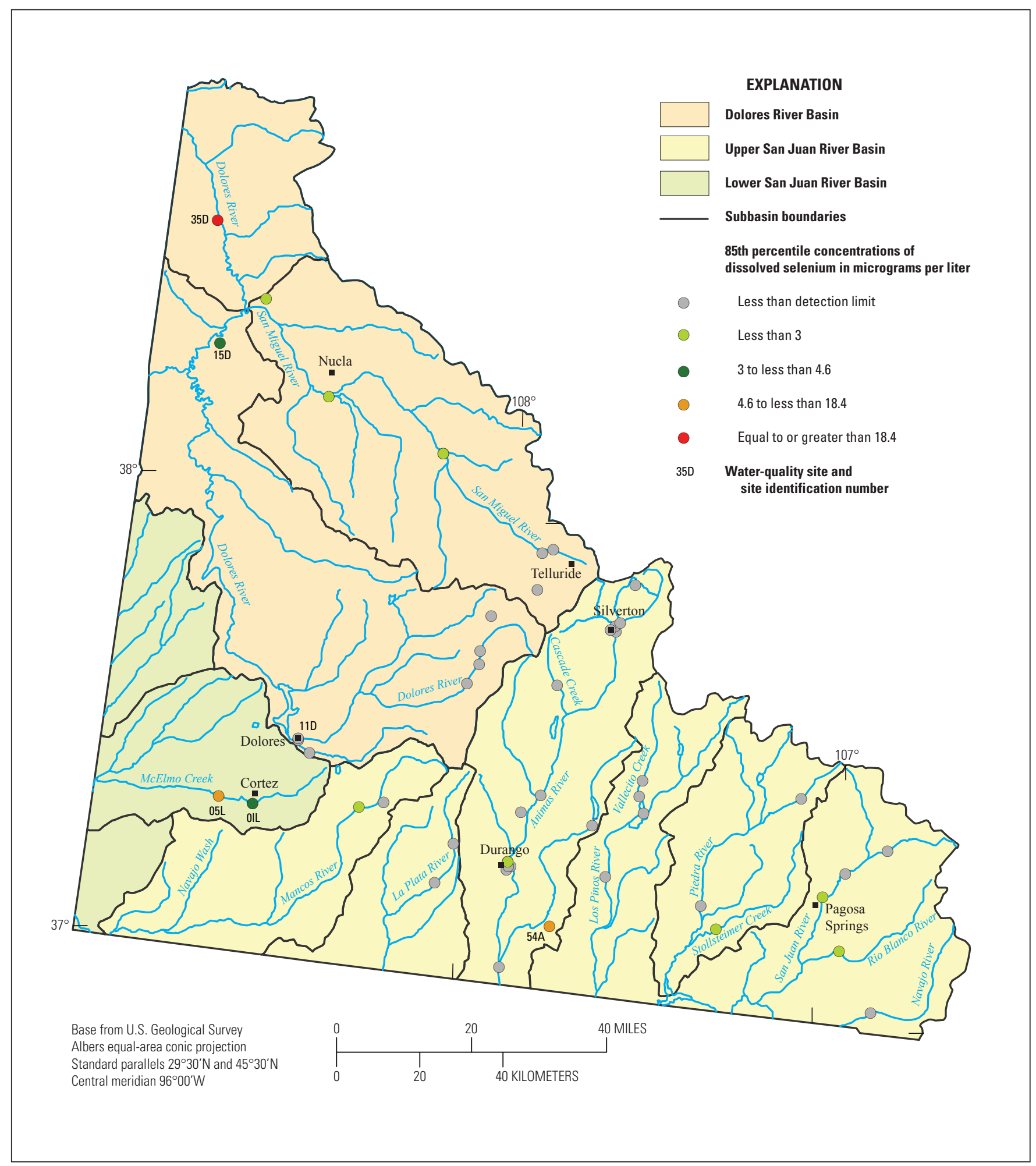

Figure 13. Map showing spatial distribution of 85th percentile concentrations of dissolved selenium in the Dolores, Upper San Juan, and Lower San Juan River Basins, southwestern Colorado, 1990-2005. 
Table 10. Statistical summary for total ammonia, nitrate plus nitrite, and total phosphorus concentrations for sites with 10 or more samples in the Dolores, Upper San Juan, and Lower San Juan River Basins, southwestern Colorado, 1990-2005.

[SiteID, site identification number; mg/L, milligram per liter; N, number of samples; NC, number of samples with concentrations reported as less than the reporting limit; Min, minimum concentration; Max, maximum concentration; Med, median concentration; $\mathrm{C}_{85}$, 85 th percentile concentration; WWTP, wastewater treatment plant; gray shaded column indicates statistic that was used for comparison to State water-quality standards]

\begin{tabular}{|c|c|c|c|c|c|c|c|}
\hline \multirow{2}{*}{$\begin{array}{l}\text { Site } \\
\text { ID }\end{array}$} & \multirow[t]{2}{*}{ Site name } & \multicolumn{6}{|c|}{$\begin{array}{l}\text { Total ammonia, } \\
\text { in mg/L as nitrogen }\end{array}$} \\
\hline & & $\mathbf{N}$ & NC & Min & Max & Med & 85th \\
\hline \multicolumn{8}{|c|}{ Dolores River Basin } \\
\hline $01 \mathrm{D}$ & Coal Creek at FR 535 below Lizard Head Wilderness Area & -- & -- & -- & -- & -- & -- \\
\hline $02 \mathrm{D}$ & Horse Creek at Highway 145 & -- & -- & -- & -- & -- & -- \\
\hline $03 \mathrm{D}$ & Dolores River above Horse Creek & -- & -- & -- & -- & -- & -- \\
\hline 04D & Silver Creek at Highway 145 & -- & -- & -- & -- & -- & -- \\
\hline $05 \mathrm{D}$ & Dolores River below Rico & -- & -- & -- & -- & -- & -- \\
\hline 07D & West Dolores River near Stoner at Highway 145 & -- & -- & -- & -- & -- & -- \\
\hline $08 \mathrm{D}$ & Lost Canyon Creek near Dolores & -- & -- & -- & -- & -- & -- \\
\hline $12 \mathrm{D}$ & Dolores River near town of Dolores & -- & -- & -- & -- & -- & -- \\
\hline $13 \mathrm{D}$ & Dolores River at Dolores above Mcphee Reservoir & -- & -- & -- & -- & -- & -- \\
\hline $15 \mathrm{D}$ & Dolores River above confluence with San Miguel River & & & & & & \\
\hline $17 \mathrm{D}$ & Lasal Creek at Utah-Colorado State Line & 23 & 23 & $<0.05$ & $<0.05$ & $<0.05$ & $<0.05$ \\
\hline $20 \mathrm{D}$ & San Miguel River above Marshall Creek & -- & -- & -- & -- & -- & -- \\
\hline $22 \mathrm{D}$ & Upstream, SMIG above Bear & -- & -- & -- & -- & -- & -- \\
\hline 24D & Downstream, SMMAHONEY & -- & -- & -- & -- & -- & -- \\
\hline $25 \mathrm{D}$ & San Miguel River at Society Turn & -- & -- & -- & -- & -- & -- \\
\hline $26 \mathrm{D}$ & South Fork San Miguel River near mouth & -- & -- & -- & -- & -- & -- \\
\hline $27 \mathrm{D}$ & Howard Fork San Miguel River at Ophir & -- & -- & -- & -- & -- & -- \\
\hline 29D & San Miguel River near Norwood & -- & -- & -- & -- & -- & -- \\
\hline $30 \mathrm{D}$ & McKenzie Creek at mouth above confluence with San Miguel River & -- & -- & -- & -- & -- & -- \\
\hline $32 \mathrm{D}$ & Naturita Creek at Naturita & -- & -- & -- & -- & -- & -- \\
\hline $34 \mathrm{D}$ & San Miguel River at confluence with Dolores River & -- & -- & -- & -- & -- & -- \\
\hline $35 \mathrm{D}$ & Salt Creek at Highway 141 & -- & -- & -- & -- & -- & -- \\
\hline $36 \mathrm{D}$ & West Creek in Unaweep Canyon & -- & -- & -- & -- & -- & -- \\
\hline 37D & Dolores River at Gateway & -- & -- & -- & -- & -- & -- \\
\hline \multicolumn{8}{|c|}{ Upper San Juan River Basin } \\
\hline $03 \mathrm{~A}$ & Eureka below Ben Franklin & -- & -- & -- & -- & -- & -- \\
\hline 09A & $\begin{array}{l}\text { North Fork Cement Creek upstream from Gold King mine, } \\
\quad \text { \#7 level (AMLI mine \# 103) }\end{array}$ & -- & -- & -- & -- & -- & -- \\
\hline $15 \mathrm{~A}$ & Porcupine Gulch upstream from mines & -- & -- & -- & -- & -- & -- \\
\hline $35 \mathrm{~A}$ & Animas River downstream from Silverton & -- & -- & -- & -- & -- & -- \\
\hline $36 \mathrm{~A}$ & Animas River near Silverton & -- & -- & -- & -- & -- & -- \\
\hline $39 \mathrm{~A}$ & Cascade Creek at Highway 550 & -- & -- & -- & -- & -- & -- \\
\hline $40 \mathrm{~A}$ & Animas River above Durango & -- & -- & -- & -- & -- & -- \\
\hline $41 \mathrm{~A}$ & Animas at Durango Mall & -- & -- & -- & -- & -- & -- \\
\hline $43 \mathrm{~A}$ & Falls Creek at 0.65 Road & -- & -- & -- & -- & -- & -- \\
\hline $46 \mathrm{~A}$ & Animas River at Durango & -- & -- & -- & -- & -- & -- \\
\hline $47 \mathrm{~A}$ & Lightner Creek at mouth at Durango & -- & -- & -- & -- & -- & -- \\
\hline $48 \mathrm{~A}$ & DRALP001 & -- & -- & -- & -- & -- & -- \\
\hline $49 \mathrm{~A}$ & Animas River at Durango & -- & -- & -- & -- & -- & -- \\
\hline $50 \mathrm{~A}$ & Animas River behind BMX track at Durango & -- & -- & -- & -- & -- & -- \\
\hline $53 \mathrm{~A}$ & Florida River below Lemon Reservoir & -- & -- & -- & -- & -- & -- \\
\hline $54 \mathrm{~A}$ & Salt Creek at 309A Road & -- & -- & -- & -- & -- & -- \\
\hline $57 \mathrm{~A}$ & Animas River near Bondad & -- & -- & -- & -- & -- & -- \\
\hline $01 \mathrm{U}$ & Little Navajo River at Highway 84 & -- & -- & -- & -- & -- & -- \\
\hline $03 \mathrm{U}$ & Rito Blanco at Highway 84 & -- & -- & -- & -- & -- & -- \\
\hline $05 \mathrm{U}$ & Sand Creek at mouth above East Fork San Juan River & -- & -- & -- & -- & -- & -- \\
\hline $09 \mathrm{U}$ & San Juan River above Pagosa Springs & -- & -- & -- & -- & -- & -- \\
\hline $10 \mathrm{U}$ & McCabe Creek above Pagosa Springs & -- & -- & -- & -- & -- & -- \\
\hline $12 \mathrm{U}$ & San Juan River below Pagosa Springs & -- & -- & -- & -- & -- & -- \\
\hline $14 \mathrm{U}$ & San Juan River above Navajo Reservoir & -- & -- & -- & -- & -- & -- \\
\hline $15 \mathrm{U}$ & East Fork Piedra River below Piedra Falls & -- & -- & -- & -- & -- & -- \\
\hline $16 U$ & Piedra River at Highway 160 & -- & -- & -- & -- & -- & -- \\
\hline $17 \mathrm{U}$ & Stollsteimer Creek at Highway 151 & -- & -- & -- & -- & -- & -- \\
\hline
\end{tabular}


Table 10. Statistical summary for total ammonia, nitrate plus nitrite, and total phosphorus concentrations for sites with 10 or more samples in the Dolores, Upper San Juan, and Lower San Juan River Basins, southwestern Colorado, 1990-2005.—Continued

[SiteID, site identification number; mg/L, milligram per liter; N, number of samples; NC, number of samples with concentrations reported as less than the reporting limit; Min, minimum concentration; Max, maximum concentration; Med, median concentration; $\mathrm{C}_{85}, 85$ th percentile concentration; WWTP, wastewater treatment plant; gray shaded column indicates statistic that was used for comparison to State water-quality standards]

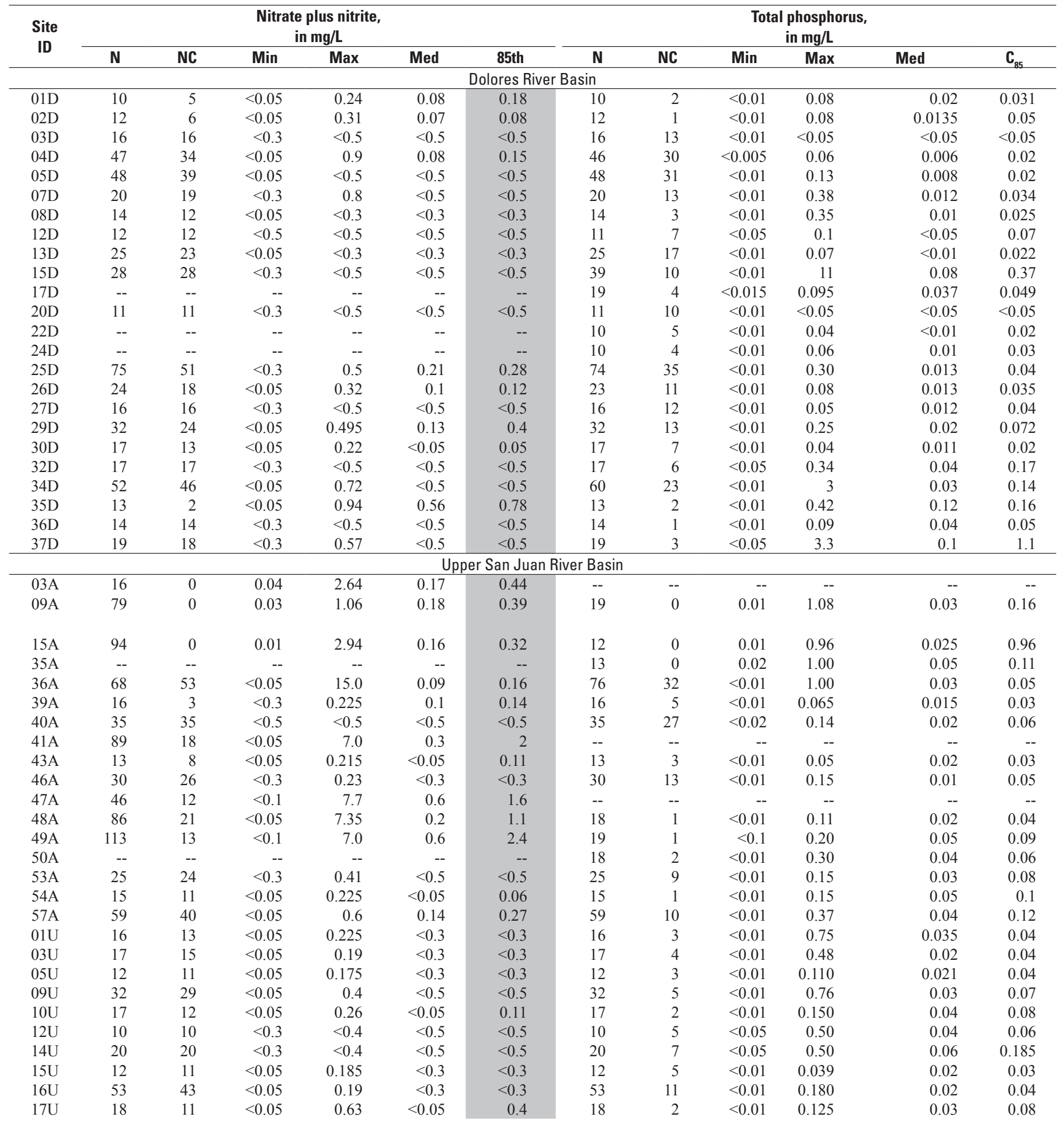


Table 10. Statistical summary for total ammonia, nitrate plus nitrite, and total phosphorus concentrations for sites with 10 or more samples in the Dolores, Upper San Juan, and Lower San Juan River Basins, southwestern Colorado, 1990-2005.—Continued

[SiteID, site identification number; mg/L, milligram per liter; $\mathrm{N}$, number of samples; NC, number of samples with concentrations reported as less than the reporting limit; Min, minimum concentration; Max, maximum concentration; Med, median concentration; $\mathrm{C}_{85}$, 85 th percentile concentration; WWTP, wastewater treatment plant; gray shaded column indicates statistic that was used for comparison to State water-quality standards]

\begin{tabular}{|c|c|c|c|c|c|c|c|}
\hline \multirow{2}{*}{$\begin{array}{l}\text { Site } \\
\text { ID }\end{array}$} & \multirow[t]{2}{*}{ Site name } & \multicolumn{6}{|c|}{$\begin{array}{c}\text { Total ammonia, } \\
\text { in mg/L as nitrogen }\end{array}$} \\
\hline & & $\mathbf{N}$ & NC & Min & Max & Med & 85th \\
\hline \multicolumn{8}{|c|}{ Upper San Juan River Basin-Continued } \\
\hline $19 \mathrm{U}$ & Piedra River northeast of Arboles & -- & -- & -- & -- & -- & -- \\
\hline $20 \mathrm{U}$ & Los Pinos River above Vallecito Reservoir near Bayfield & 22 & 14 & $<0.002$ & 0.039 & $<0.002$ & 0.006 \\
\hline $21 \mathrm{U}$ & Los Pinos River above Vallecito Reservoir & -- & -- & -- & -- & -- & -- \\
\hline $22 \mathrm{U}$ & Vallecito Creek near Bayfield & 177 & 121 & $<0.002$ & 0.03 & 0.003 & 0.006 \\
\hline $23 \mathrm{U}$ & Vallecito Creek near mouth & -- & -- & -- & -- & -- & -- \\
\hline $24 \mathrm{U}$ & Los Pinos River below Vallecito Reservoir near Bayfield & 17 & 3 & $<0.002$ & 0.017 & 0.008 & 0.013 \\
\hline $25 \mathrm{U}$ & Wallace Gulch at 502 Road north of Bayfield & -- & -- & -- & -- & -- & -- \\
\hline $28 \mathrm{U}$ & Los Pinos River near La Boca & -- & -- & -- & -- & -- & -- \\
\hline $30 \mathrm{U}$ & La Plata at Hesperus & -- & -- & -- & -- & -- & -- \\
\hline $31 \mathrm{U}$ & Spring Creek near Breen & -- & -- & -- & -- & -- & -- \\
\hline $32 \mathrm{U}$ & East Fork Mancos River at 44 Road & -- & -- & -- & -- & -- & -- \\
\hline $34 \mathrm{U}$ & Chicken Creek at Mancos & -- & -- & -- & -- & -- & -- \\
\hline \multicolumn{8}{|c|}{ Lower San Juan River Basin } \\
\hline $01 \mathrm{~L}$ & McElmo Creek above Cortez Sanitation District, Southwest WWTP & -- & -- & -- & -- & -- & -- \\
\hline $05 \mathrm{~L}$ & McElmo Creek above Trail Canyon at gage & -- & -- & -- & -- & -- & -- \\
\hline
\end{tabular}

Table 10. Statistical summary for total ammonia, nitrate plus nitrite, and total phosphorus concentrations for sites with 10 or more samples in the Dolores, Upper San Juan, and Lower San Juan River Basins, southwestern Colorado, 1990-2005.—Continued

[SiteID, site identification number; $\mathrm{mg} / \mathrm{L}$, milligram per liter; $\mathrm{N}$, number of samples; $\mathrm{NC}$, number of samples with concentrations reported as less than the reporting limit; Min, minimum concentration; Max, maximum concentration; Med, median concentration; $\mathrm{C}_{85}, 85$ th percentile concentration; WWTP, wastewater treatment plant; gray shaded column indicates statistic that was used for comparison to State water-quality standards]

\begin{tabular}{|c|c|c|c|c|c|c|c|c|c|c|c|c|}
\hline $\begin{array}{l}\text { Site } \\
\text { ID }\end{array}$ & \multicolumn{6}{|c|}{$\begin{array}{l}\text { Nitrate plus nitrite, } \\
\text { in } \mathrm{mg} / \mathrm{L}\end{array}$} & \multicolumn{6}{|c|}{$\begin{array}{l}\text { Total phosphorus, } \\
\text { in } \mathrm{mg} / \mathrm{L}\end{array}$} \\
\hline \multicolumn{13}{|c|}{ Upper San Juan River Basin-Continued } \\
\hline $20 \mathrm{U}$ & -- & -- & -- & -- & -- & -- & 17 & 1 & $<0.008$ & 0.051 & 0.01 & 0.03 \\
\hline $21 \mathrm{U}$ & 52 & 34 & $<0.05$ & 0.22 & 0.06 & 0.11 & 52 & 28 & $<0.01$ & 0.13 & $<0.01$ & 0.02 \\
\hline $22 \mathrm{U}$ & 10 & 0 & 0.064 & 0.21 & 0.115 & 0.16 & 47 & 26 & $<0.002$ & 0.060 & 0.004 & 0.02 \\
\hline $23 \mathrm{U}$ & 52 & 27 & $<0.05$ & 0.32 & 0.16 & 0.2 & 52 & 33 & $<0.01$ & 0.07 & $<0.01$ & 0.02 \\
\hline $28 \mathrm{U}$ & 10 & 9 & $<0.5$ & 0.285 & $<0.5$ & $<0.5$ & 10 & 4 & $<0.05$ & 0.20 & 0.06 & 0.13 \\
\hline $30 \mathrm{U}$ & 40 & 30 & $<0.05$ & 0.305 & 0.02 & 0.1 & 40 & 28 & $<0.005$ & 0.17 & 0.005 & 0.02 \\
\hline $31 \mathrm{U}$ & 12 & 9 & $<0.05$ & 0.09 & $<0.05$ & 0.07 & 12 & 2 & $<0.01$ & 0.08 & 0.02 & 0.03 \\
\hline $32 \mathrm{U}$ & 22 & 14 & $<0.05$ & 0.225 & 0.04 & 0.08 & 22 & 13 & $<0.01$ & 0.18 & $<0.01$ & 0.031 \\
\hline $34 \mathrm{U}$ & 18 & 14 & $<0.05$ & 0.21 & $<0.05$ & 0.08 & 18 & 1 & $<0.01$ & 0.08 & 0.02 & 0.034 \\
\hline \multicolumn{13}{|c|}{ Lower San Juan River Basin } \\
\hline
\end{tabular}




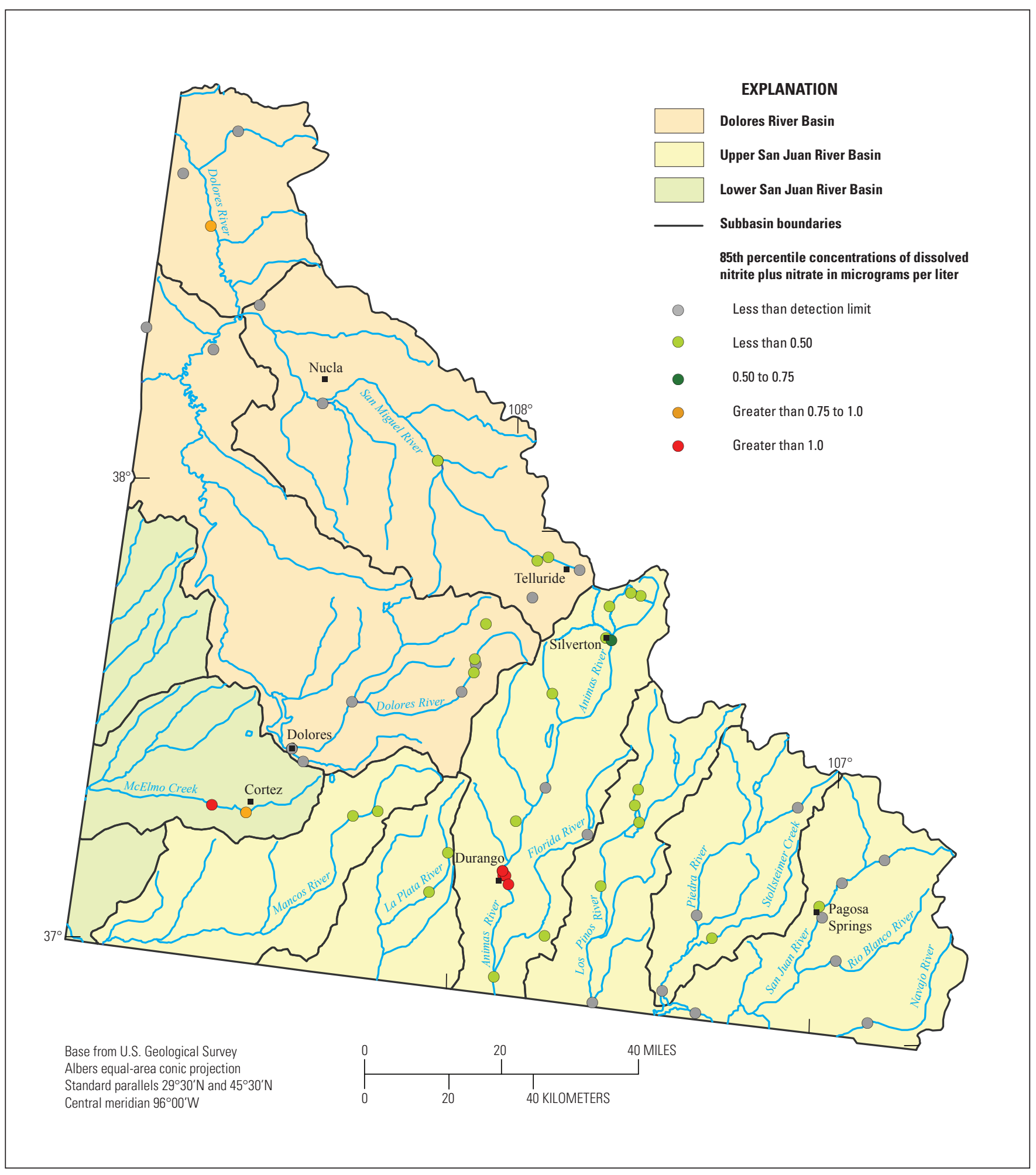

Figure 14. Map showing spatial distribution of 85th percentile concentrations of nitrate plus nitrite in the Dolores, Upper San Juan, and Lower San Juan River Basins, southwestern Colorado, 1990-2005. 
The highest 85 th percentile total phosphorus concentration occurred at the Dolores River at Gateway (site 37D). Adequate data were not available to analyze temporal trends in total phosphorus concentrations in the Dolores River Basin.

Upper San Juan River Basin.-Adequate data were available for 36 sites to calculate summary statistics for total phosphorus concentrations. The 85th percentile total phosphorus concentrations ranged from 0.009 to $0.96 \mathrm{mg} / \mathrm{L}$ (table 10). Total phosphorus concentrations in the Upper SJRB were typically near the reporting limits and were not significantly different seasonally. The highest 85 th percentile total phosphorus concentration $(0.96 \mathrm{mg} / \mathrm{L})$ occurred at the Porcupine Gulch upstream from mines (site 15A) near Silverton. Adequate data were not available to analyze temporal trends in total phosphorus concentrations in the Upper SJRB.

Lower San Juan River Basin.-Only the McElmo Creek above Cortez Sanitation District, Southwest WWTP and McElmo Creek above Trail Canyon sites had sufficient data to calculate summary statistics for total phosphorus in the Lower SJRB. The 85th percentile total phosphorus concentrations ranged from $0.19 \mathrm{mg} / \mathrm{L}$ at McElmo Creek above Cortez Sanitation District, Southwest WWTP to $0.38 \mathrm{mg} / \mathrm{L}$ at McElmo Creek above Trail Canyon (table 10). Total phosphorus concentrations were significantly higher in samples collected during the summer period than in samples collected during the winter period. Adequate data were not available to analyze temporal trends in total phosphorus concentrations in the Lower SJRB.

\section{Uranium}

Only 10 sites throughout the entire study area had adequate data to calculate summary statistics for dissolved uranium (table 8). The 85th percentile concentrations of dissolved uranium ranged from less than 3 to $10 \mu \mathrm{g} / \mathrm{L}$, well below the national drinking water water-quality standard of $30 \mu \mathrm{g} / \mathrm{L}$ (U.S. Environmental Protection Agency, 2010a). Dissolved uranium concentrations were generally less than $5 \mu \mathrm{g} / \mathrm{L}$ in most samples from most streams; although concentrations greater than $10 \mu \mathrm{g} / \mathrm{L}$ were measured in some samples at various locations throughout the study area, particularly at sites in the Lower SJRB and along Navajo Wash in the southwestern part of the Upper SJRB (fig. 15). Many of these site locations, where dissolved uranium concentrations were elevated, coincide with areas where the Mancos Shale crops out. Because the solubility of uranium is high, geochemical exploration for uranium is commonly done using water and stream sediments as sampling media to identify areas of abnormally high concentrations (Wenrich-Verbeek, 1980). The highest concentrations of dissolved uranium in the study area were detected at sites along Navajo Wash (fig. 15). Navajo Wash receives irrigation drainage from areas on Mancos Shale (Butler and others, 1997). Pliler and Adams (1962) reported that the average concentration of uranium was 3.7 milligrams per kilogram in samples from the Mancos Shale in Colorado,
Utah, Arizona, and New Mexico (Pliler and Adams, 1962). Uranium-vanadium deposits occur in the Salt Wash member of the Morrison Formation in southwestern Colorado (GeoXplor Corp, 2009). Irrigation drainage likely leaches uranium from the Mancos Shale and other deposits containing uranium into groundwater and surface water that enters Navajo Wash.

\section{Summary of Trends in Selected Water- Quality Characteristics}

Temporal trends in DO, $\mathrm{pH}$, water temperature, SC, DS, chloride, sulfate, nitrate plus nitrite, and selected trace element values were evaluated at sites with adequate data. Only one site, Vallecito Creek near Bayfield, had sufficient DO data to perform trend analysis. No significant trend in DO concentrations occurred at the site. Small (less than 0.5 percent) statistically significant increases in $\mathrm{pH}$ values occurred at the Dolores River at Bedrock, Dolores River near Bedrock, Mud Creek at State Highway 32, near Cortez, and McElmo Creek above Trail Canyon near Cortez sites. These small upward trends in $\mathrm{pH}$ values may result from changes in stream water quality resulting from land and(or) water use changes or simply be an artifact of changes in sampling routines. A significant decrease of 2.4 percent in $\mathrm{pH}$ values (1993-2003) occurred at the Animas River downstream from Silverton site. No other significant trends in $\mathrm{pH}$ values occurred.

Significant upward trends in water temperature occurred at the Los Pinos River at La Boca and the San Juan River at Pagosa Springs sites located in the Upper SJRB. A 3.5 percent increase in water temperature occurred at the Los Pinos River at La Boca site where the typical water temperature for the period of analysis $(1993-2003)$ was $10.9^{\circ} \mathrm{C}$. An increase of 3.9 percent occurred at the San Juan River at Pagosa Springs site where the typical water temperature for the period of analysis was $5.7^{\circ} \mathrm{C}$. Instantaneous streamflow values measured when water-quality samples were collected were generally lower during the last half of the analysis period than during the first half of the analysis period. These upward trends in water temperature may result from changes in groundwater and surface water interactions and(or) changes in stream velocities and depths because of drought conditions during the latter part of the analysis period. No significant trends in water temperature values occurred at sites in the Dolores River Basin or the Lower SJRB.

Significant decreases in SC values and DS and chloride concentrations occurred at the Dolores River near Bedrock site downstream from the Paradox Valley Unit. Specific conductance values decreased by 8.9 percent, DS concentrations decreased by 8.3 percent, and chloride concentrations decreased by 10.5 percent in samples collected from 1993 through 2003. These decreases in SC values and DS and chloride concentrations are likely because of the operation of the Paradox Valley Unit (described in the Geology section of the report) upstream from the site. No significant trends in SC 


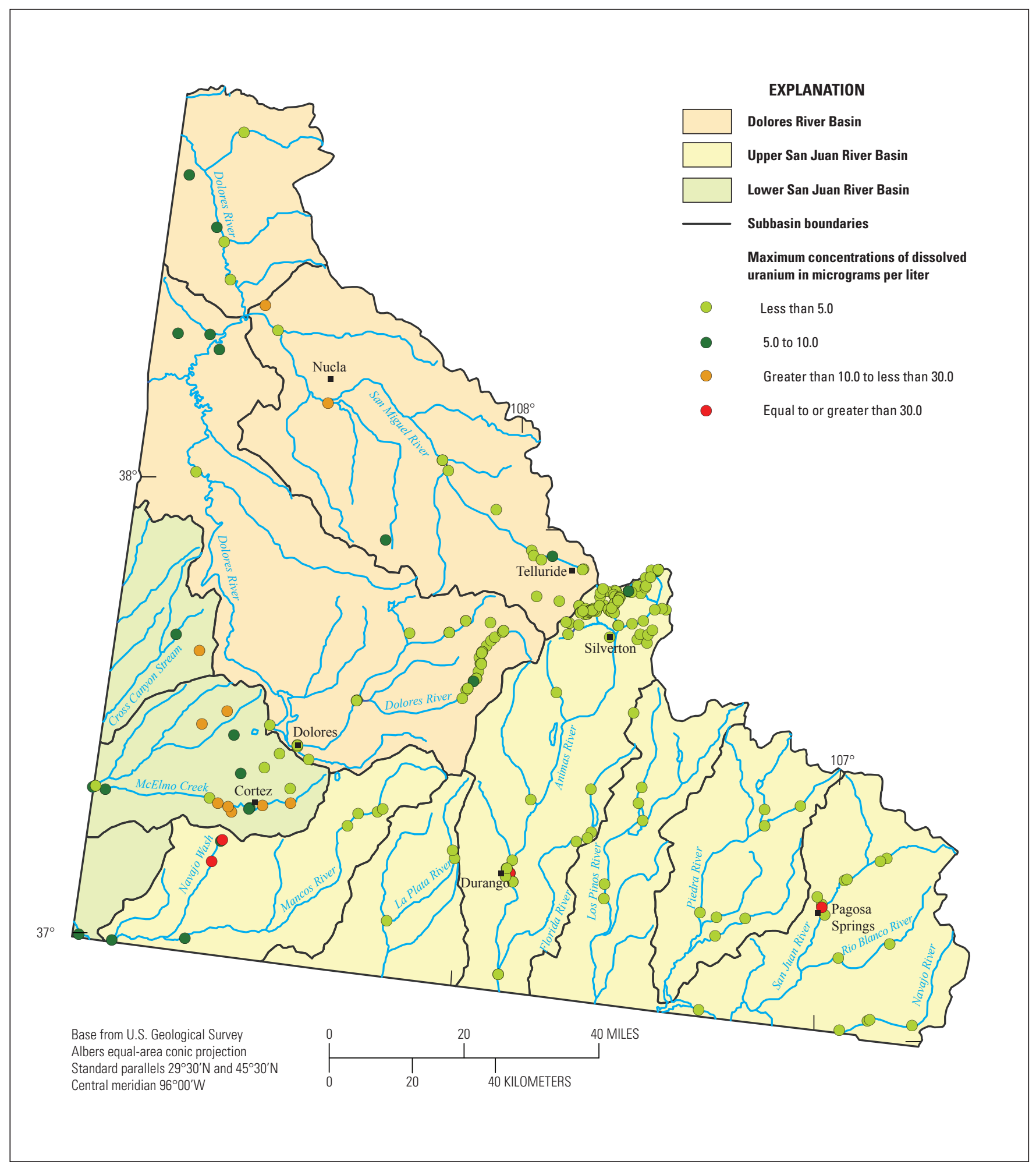

Figure 15. Map showing spatial distribution of maximum uranium concentrations in the Dolores, Upper San Juan, and Lower San Juan River Basins, southwestern Colorado, 1990-2005. 
values, DS concentrations, or chloride concentrations occurred at other sites in the Dolores River Basin; no significant trends in sulfate concentrations occurred at any site in the Dolores River Basin.

Significant downward trends in SC values were detected at 4 of the 13 sites analyzed in the Upper SJRB. The largest percent decrease in $\mathrm{SC}$ values was detected at Mancos River near Towaoc. This decrease may be the result of salinity control modifications done by the Natural Resources Conservation Service (Environmental Quality Improvement Program) and the Bureau of Reclamation (Colorado River Basin Salinity Control Program) as part of the Mancos Valley Salinity Control Project. Significant downward trends in SC values were also detected at Animas River below Silverton, Spring Creek at La Boca, and Los Pinos River at La Boca. At the Animas River below Silverton site, downward trends in SC and $\mathrm{pH}$ values may be because of changes made in the drainage basin to control acid mine drainage. Downward trends in $\mathrm{SC}$ values at Spring Creek at La Boca and Los Pinos River at La Boca may result from channel improvements made to decrease sedimentation, changes in irrigation practices, or other changes in water use within the watersheds.

In the Lower SJRB, significant downward trends in $\mathrm{SC}$ values and DS and sulfate concentrations occurred at the McElmo Creek above Trail Canyon near Cortez site. Significant downward trends in DS concentrations and sulfate concentrations occurred at the Mud Creek at State Highway 32, near Cortez site. Downstream from these sites, at the McElmo Creek near Colorado-Utah State line site, significant downward trends in $\mathrm{SC}$ values and DS, chloride, and sulfate concentrations occurred. These downward trends may be because of irrigation and water-delivery system improvements made by the BOR in the McElmo Creek basin.

The Vallecito Creek near Bayfield site was the only site in the Upper SJRB that had sufficient data to perform trend analyses for DS, chloride, sulfate, and nitrate plus nitrite. No significant trends in DS, chloride, or nitrate plus nitrite concentrations occurred at the site; however, a significant upward trend in sulfate concentrations of 4.0 percent was measured. This trend in sulfate concentrations may be related to the drought conditions during the latter part of the analysis period which may have lowered the water table levels and affected groundwater contributions.

Only the Animas River at Silverton, Animas River downstream from Silverton, and Mineral Creek at Silverton sites had adequate data to analyze for temporal trends (1991-2004) in most selected trace element concentrations. No trends in trace element concentrations occurred at Animas River at Silverton or at Animas River downstream from Silverton. Significant downward trends in total recoverable lead, dissolved zinc, and total recoverable zinc concentrations occurred at Mineral Creek at Silverton.

Overall results from the trend analyses indicate improvement in water-quality conditions as a result of operation of the Paradox Valley Unit in the Dolores River Basin and irrigation and water-delivery system improvements made in the McElmo
Creek basin and Mancos River Valley. Other detected trends may be because of precipitation variability during the analysis period. Additional study, however, would be needed to determine the causes of the apparent changes in water-quality characteristic values over time at the sites.

\section{Summary}

In 2004, the U.S. Geological Survey (USGS) in cooperation with Bureau of Land Management (BLM), Bureau of Reclamation (BOR), Southwestern Water Conservation District (WCD), San Miguel County, and Telluride Power/ Water began a surface-water and groundwater assessment of the Dolores River and San Juan River Basins in southwestern Colorado. As part of this assessment, historical water-quality data collected in the Dolores and San Juan River Basins (Southwest Study Area) by various local, State, Tribal, and Federal agencies were compiled into a single electronic database. Selected surface-water quality data from this database (1990-2005) were analyzed to determine the spatial and temporal distribution of physical and chemical water-quality characteristics. Results from this analysis and previous studies done by others were used to describe environmental and landuse factors which affect surface-water-quality conditions in southwestern Colorado.

Minimum, maximum, median, and other selected percentile values were calculated using available surface-water-quality data for sites with 10 or more samples. These values were compared to State and(or) Federal water-quality standards to assess existing water quality in southwestern Colorado. Trend analyses for dissolved oxygen (DO), $\mathrm{pH}$, water temperature, specific conductance (SC), dissolved solids (DS), chloride, and sulfate data were done for the period January 1993 through December 2003 and for selected trace metals data for the period January 1991 through December 2004. The spatial and temporal distribution of $\mathrm{DO}, \mathrm{pH}$, water temperature, DS, major ions, selected trace elements, nutrients, and uranium data were described spatially by location within the Dolores, Upper San Juan, and Lower San Juan River Basins.

Overall, streams throughout the study area were well oxygenated. Median DO concentrations generally ranged from 8 to 10 milligrams per liter $(\mathrm{mg} / \mathrm{L})$. The 15 th percentile DO concentrations ranged from 5.0 to $8.9 \mathrm{mg} / \mathrm{L}$ in the Dolores River Basin, from 0.1 to $9.7 \mathrm{mg} / \mathrm{L}$ in the Upper San Juan River Basin (SJRB), and from 7.2 to $7.6 \mathrm{mg} / \mathrm{L}$ in the Lower SJRB.

Values of $\mathrm{pH}$ in surface water generally were near neutral to slightly alkaline throughout most of the study area with the exception of the upper Animas River Basin (within the Upper SJRB) near Silverton where acidic conditions existed at some sites because of hydrothermal alteration and(or) historical mining. In the Upper SJRB, 15th percentile values for $\mathrm{pH}$ ranged from 1.6 to 7.9 , and 85 th percentile $\mathrm{pH}$ values ranged from 2.6 to 8.7 standard units. One site in the Mineral Creek basin and two sites in the Cement Creek basin had 
15th percentile values for $\mathrm{pH}$ less than 3.7, the lowest designated State surface-water-quality standard value for $\mathrm{pH}$ in the study area.

Mean water temperatures in the study area ranged from 5.3 to $14.1^{\circ} \mathrm{C}$. Instantaneous water temperatures varied from less than 0 to $31.5^{\circ} \mathrm{C}$. Sites located in the headwaters of the Dolores River Basin and the Upper SJRB typically had mean water temperatures less than $10^{\circ} \mathrm{C}$. Lower elevation sites throughout the study area generally had mean water temperatures between 9 and $13{ }^{\circ} \mathrm{C}$.

Median DS concentrations ranged from 8 to $42,600 \mathrm{mg} / \mathrm{L}$. The highest DS concentrations typically occurred in samples collected from December through March when streamflows were lowest and groundwater inflow was the dominant source of flow. The lowest DS concentrations typically occurred in samples collected from May through July when streamflows were highest and snowmelt was the dominant source of the flow. Seasonal differences in DS concentrations were more apparent in samples from the Upper SJRB and the Lower SJRB than the Dolores River Basin. In the Dolores River Basin, 14 of the 22 sites analyzed had median DS concentrations less than $500 \mathrm{mg} / \mathrm{L}$. Thirty-one of the 32 sites analyzed in the Upper SJRB had median DS concentrations less than $500 \mathrm{mg} / \mathrm{L}$; and many sites had median DS concentrations less than $250 \mathrm{mg} / \mathrm{L}$. Median DS concentrations ranged from 1,340 to $3,385 \mathrm{mg} / \mathrm{L}$ at sites analyzed in the Lower SJRB.

Eighty-fifth percentile concentrations for dissolved aluminum ranged from less than 50 to $67,000 \mu \mathrm{g} / \mathrm{L}$; and median total recoverable aluminum concentrations ranged from 57 to 2,000 $\mu \mathrm{g} / \mathrm{L}$. In the Upper SJRB, two sites had 85th percentile concentrations of dissolved aluminum (used as surrogate for total recoverable aluminum) that exceeded the acute hardness-based criteria, and 11 sites had 85 th percentile concentrations of dissolved aluminum that exceeded the chronic hardness-based criteria. All of the sites that exceeded the acute criteria and all but one site that exceeded the chronic criteria were located in the Cement and Mineral Creek basins north and west of Silverton.

Median total recoverable iron concentrations ranged from 1.6 to $225,000 \mu \mathrm{g} / \mathrm{L}$. It was common for total recoverable iron concentrations to vary over several orders of magnitude at a given site. The highest median total recoverable iron concentrations in the study area generally occurred at sites in the Cement Creek and Mineral Creek Basins in the Upper SJRB north and west of Silverton. In the Dolores River Basin, median total recoverable iron concentrations ranged from 4.8 to $450 \mu \mathrm{g} / \mathrm{L}$ and were less than $300 \mu \mathrm{g} / \mathrm{L}$ at 16 of the 17 sites analyzed. Median total recoverable iron concentrations equal to or greater than $1,000 \mu \mathrm{g} / \mathrm{L}$ occurred at 10 sites in the Upper SJRB. The remaining sites in the Upper SJRB had median total recoverable iron concentrations less than $800 \mu \mathrm{g} / \mathrm{L}$; and most sites had median concentrations less than $450 \mu \mathrm{g} / \mathrm{L}$. In the Lower SJRB, median total recoverable iron concentrations in McElmo Creek were $890 \mu \mathrm{g} / \mathrm{L}$ at McElmo Creek above
Cortez Sanitation District, Southwest WWTP and 1,500 $\mu \mathrm{g} / \mathrm{L}$ at McElmo Creek above Trail Canyon.

One or more samples were collected and analyzed for total (unfiltered recoverable) mercury at 156 sites. Concentrations of total mercury measured in samples from these sites ranged from less than 0.005 to $12 \mu \mathrm{g} / \mathrm{L}$. Reporting limits for mercury typically ranged from 0.005 to $1 \mu \mathrm{g} / \mathrm{L}$. At least one measured concentration of total mercury exceeded the State chronic aquatic-life criterion of $0.01 \mu \mathrm{g} / \mathrm{L}$ for 32 of the 156 sites sampled. Determining the actual distribution of mercury in surface water throughout the study area was not possible because reporting limits often varied at sites and were usually higher than the aquatic-life criterion.

Many of the dissolved lead concentrations in samples were censored. Reporting limits for lead varied from 1 to 50 $\mu \mathrm{g} / \mathrm{L}$ and were often greater than the calculated chronic criteria. In the Dolores River Basin, only two sites had 85th percentile concentrations of dissolved lead greater than the individual reporting limits. Both sites had 85 th percentile concentrations of dissolved lead equal to $1 \mu \mathrm{g} / \mathrm{L}$. The 85 th percentile concentrations for dissolved lead ranged from less than 1 to $250 \mu \mathrm{g} / \mathrm{L}$ at sites in the Upper SJRB. The highest dissolved lead concentrations in the Upper SJRB generally occurred in the Mineral and Cement Creek basins. State criteria in these areas were based on total recoverable lead concentrations, and median concentrations of total recoverable lead did not exceed criteria. In the Lower SJRB, almost all dissolved lead concentrations were censored.

The 85th percentile concentrations for dissolved zinc ranged from less than 2 to $180,000 \mu \mathrm{g} / \mathrm{L}$; although, most sites in the study area generally had 85th percentile concentrations less than $200 \mu \mathrm{g} / \mathrm{L}$. Four sites in the Dolores River Basin had dissolved zinc concentrations that exceeded State acute and chronic hardness-based criteria. Twenty-four sites in the Upper SJRB had 85th percentile concentrations that exceeded acute and chronic hardness-based standards. Sites with concentrations of dissolved zinc that exceeded State acute and chronic hardness-based standards in the Upper SJRB may not have exceeded segment-specific monthly standards; but monthly concentrations were not calculated. In the Lower SJRB, 85th percentile concentrations of dissolved zinc were well below the State hardness-based criteria.

Dissolved selenium concentrations in samples ranged from less than 0.2 to $170 \mu \mathrm{g} / \mathrm{L}$ in the study area. One site in the Dolores River Basin, Salt Creek at Highway 141 (site 35D), had an 85 th percentile concentration of dissolved selenium equal to $23 \mu \mathrm{g} / \mathrm{L}$ which exceeded the State chronic $(4.6 \mu \mathrm{g} / \mathrm{L})$ and acute standards $(18.4 \mu \mathrm{g} / \mathrm{L})$. Most sites in the Dolores River Basin had 85 th percentile concentrations equal to or less than $3 \mu \mathrm{g} / \mathrm{L}$. In the Upper SJRB, 85th percentile dissolved selenium concentrations ranged from less than 1 to $11 \mu \mathrm{g} / \mathrm{L}$. Most sites in the Upper SJRB had 85th percentile dissolved selenium concentrations less than $3 \mu \mathrm{g} / \mathrm{L}$. One site, Salt Creek at 309A Road, in the Upper SJRB had an 85th percentile concentration of dissolved selenium that 
exceeded the State chronic standard. Dissolved selenium concentrations greater than the acute water-quality standard occurred in some samples along Navajo Wash in the southwestern corner of the Upper SJRB, but insufficient data were available to compute summary statistics. In the Lower SJRB, at McElmo Creek above Trail Canyon, the 85th percentile dissolved selenium concentration was equal to $5 \mu \mathrm{g} / \mathrm{L}$ and exceeded the State chronic standard. Dissolved selenium concentrations greater than the acute water-quality standard occurred in some samples collected from Mud Creek sites near Cortez, but insufficient data were available to compute summary statistics.

Concentrations of total ammonia, nitrate, nitrite, and total phosphorus generally were low throughout the study area. The 85th percentile concentrations of total ammonia were less than the calculated chronic and acute State table-value standards for total ammonia. Nitrate plus nitrite concentrations ranged from less than 0.05 to $15 \mathrm{mg} / \mathrm{L}$ in samples; and 87 percent of samples analyzed had concentrations less than or equal to $0.5 \mathrm{mg} / \mathrm{L}$. In the Dolores River Basin, 85th percentile nitrate plus nitrite concentrations at the 21 sites analyzed ranged from less than 0.05 to $0.78 \mathrm{mg} / \mathrm{L}$. In the Upper SJRB, 85th percentile nitrate plus nitrite concentrations at the 35 sites analyzed ranged from less than 0.06 to $2.4 \mathrm{mg} / \mathrm{L}$. Only 4 sites in the Upper SJRB had 85th percentile concentrations of nitrate plus nitrite that exceeded $1 \mathrm{mg} / \mathrm{L}$. These sites were located in the vicinity of Durango mostly on the Animas River. In the Lower SJRB, the 85th percentile nitrate plus nitrite concentration was equal to $1 \mathrm{mg} / \mathrm{L}$ at the McElmo Creek above Cortez Sanitation District, Southwest WWTP site and $2.7 \mathrm{mg} / \mathrm{L}$ downstream at the McElmo Creek above Trail Canyon at gage site. Concentrations of nitrate plus nitrate in the Lower SJRB were significantly ( $p$-value $<0.01$ ) higher in samples collected during the winter than in samples collected during the summer. Total phosphorus concentrations ranged from less than 0.002 to $11 \mathrm{mg} / \mathrm{L}$, though concentrations in most samples were less than $0.1 \mathrm{mg} / \mathrm{L}$.

Only 10 sites throughout the entire study area had adequate data to calculate summary statistics for dissolved uranium. The 85th percentile concentrations of dissolved uranium ranged from less than 3 to $10 \mu \mathrm{g} / \mathrm{L}$, well below the national drinking water water-quality standard of $30 \mu \mathrm{g} / \mathrm{L}$. Although dissolved uranium concentrations in most samples from most streams were less than $5 \mu \mathrm{g} / \mathrm{L}$, concentrations of dissolved uranium greater than $10 \mu \mathrm{g} / \mathrm{L}$ were measured in some samples at various locations throughout the study area, particularly at sites in the Lower SJRB and along Navajo Wash in the Upper SJRB. Many of these site locations, where dissolved uranium concentrations were elevated, coincide with areas where the Mancos Shale crops out.

In the Dolores River Basin, significant downward trends in SC values and DS and chloride concentrations were detected at the Dolores River near Bedrock site downstream from the Paradox Valley Unit. Significant downward trends in $\mathrm{SC}$ values were detected at 4 of the 13 sites analyzed in the Upper SJRB. In the Lower SJRB, significant downward trends were detected in SC values and DS and sulfate concentrations at the McElmo Creek above Trail Canyon near Cortez site and in DS and sulfate concentrations at the Mud Creek at State Highway 32, near Cortez site. Downstream from these sites, at the McElmo Creek near Colorado-Utah State line site, significant downward trends in SC values and DS, chloride, and sulfate concentrations were observed. Trend tests for trace elements were limited to three sites in the Silverton area, of which one (Mineral Creek at Silverton) showed significant downward trends in total recoverable lead, dissolved zinc, and total zinc concentrations.

Overall results from the trend analyses indicate improvement in water-quality conditions as a result of operation of the Paradox Valley Unit in the Dolores River Basin and irrigation and water-delivery system improvements made in the McElmo Creek Basin and Mancos River Valley. Other detected trends period. Additional study, however, would be needed to determine the causes of the apparent changes in water-quality characteristic values over time at the sites.

\section{Selected References}

Bartos, T.T., and Ogle, K.M., 2002, Water quality and environmental isotopic analyses of groundwater samples collected from the Wasatch and Fort Union Formations in areas of coalbed methane development: implications to recharge and ground-water flow, eastern Powder River Basin, Wyoming: U.S. Geological Survey Water Resources Investigations Report 2002-4045, 88 p.

Besser, J.M., and Leib K.J., 1999, Modeling frequency of occurrence of toxic concentrations of zinc and copper in the Upper Animas River, in Morganwalp, D.W., and Buxton, H.T., eds., U.S. Geological Survey Toxic Substances Hydrology Program-Proceedings of the Technical Meeting, Charleston, South Carolina, March 8-12, 1999: U.S. Geological Survey Water-Resources Investigations Report 99-4018A, p. 75-81.

Bureau of Reclamation, 2011, Colorado River Basin Salinity Control Project-Paradox Valley Unit-Tilte II: Information available on the Web, accessed February 16, 2011, at http://www.usbr.gov/projects/Project.jsp?proj_ Name $=$ CRBSCP - Paradox Valley Unit - Title II

Butler, D.L., 2001, Effects of piping irrigation laterals on selenium and salt loads, Montrose Arroyo Basin, western Colorado: U.S. Geological Survey Water-Resources Investigations Report 01-4204, $14 \mathrm{p}$.

Butler, D.L., and Leib, K.J., 2002, Characterization of selenium in the Lower Gunnison River Basin, Colorado, 1988-2000: U.S. Geological Survey Water-Resources Investigations Report 02-4151, 26 p. 
Butler, D.L., Osmundson, B.C., and Krueger, R.P., 1997, Field screening of water, soil, bottom sediment, and biota associated with irrigation drainage in the Dolores Project and the Mancos River Basin, southwestern Colorado, 1994:

U.S. Geological Survey Water-Resources Investigations Report 97-4008, 43 p.

Butler, D.L., Wright, W.G., Stewart, K.C., Osmundson, B.C., Krueger, R.P., and Crabtree, D.W., 1996, Detailed study of selenium and other constituents in water, bottom sediment, soil, alfalfa, and biota associated with irrigation drainage in the Uncompahgre Project Area and in the Grand Valley, west-central Colorado, 1991-93: U.S. Geological Survey Water-Resources Investigations Report 96-4138, 136 p.

Chafin, D.T., 2003, Effect of the Paradox Valley Unit on the dissolved-solids load of the Dolores River near Bedrock, Colorado, 1988-2001: U.S. Geological Survey WaterResources Investigations Report 2002-4275, 6 p.

Church, S.E., Kimball, B.A., Fey, D.L., Ferderer, D.A., Yager, T.J., Vaughn, R.B., 1997, Source, transport, and partitioning of metals between water, colloids, and bed sediments of the Animas River, Colorado: U.S. Geological Survey Open-File Report 97-151, 135 p.

Church, S.E., von Guerard, P., and Finger, S.E., eds., 2007, Integrated investigations of environmental effects of historical mining in the Animas River watershed, San Juan County, Colorado: U.S. Geological Survey Professional Paper 1651, 1,096 p.

Colorado Department of Public Health and Environment, 2010a, Surface water quality classifications and standards, regulation 34-classifications and numeric standards for San Juan River and Dolores River Basins (amended 2/8/10, effective 6/30/10) and tables, accessed September 13, 2010, at $h t t p: / / w w w . c d p h e . s t a t e . c o . u s /$ regulations/wqccregs/.

Colorado Department of Public Health and Environment, 2010b, Surface water quality classifications and standards, regulation 31-the basic standards and methodologies for surface water (amended 10/13/09, effective 11/30/09) and tables, accessed September 13, 2010, at http://www.cdphe. state.co.us/regulations/wqccregs/.

Daly, C., Gibson, W.P., Taylor, G.H., Johnson, G.L., and Pasteris, P., 2002, A knowledge-based approach to the statistical mapping of climate: Climate Research, v. 22, p. 99-113.

GeoXplor Corp, 2009, Uravan mineral claims: accessed June 15, 2011, at $h t t p: / / w w w$ firstlibertypower.com/files/FLPCUravan_Mineral_Claims_Report.pdf/.

Helsel, D.R., 2005, Nondetects and data analysis-Statistics for censored environmental data: Hoboken, N.J., John Wiley \& Sons, Inc., $250 \mathrm{p}$.
Helsel, D.R., and Hirsch R.M., 2002, Statistical methods in water resources: U.S. Geological Survey Techniques of Water-Resources Investigations, book 4, chap. A3, 510 p.

Hem, J.D., 1985, Study and interpretation of the chemical characteristics of natural water: U.S. Geological Survey Water-Supply Paper 2254, $264 \mathrm{p}$.

Hirsch, R.M., and Slack, J.R., 1984, A nonparametric trend test for seasonal data with serial dependence: Water Resources Research, v. 20, no. 6, p. 727-732.

Hirsch, R.M., Slack, J.R., and Smith, R.A., 1982, Techniques of trend analysis for monthly water quality data: Water Resources Research, v. 18, no. 1, p. 107-121.

Krabbenhoft, D.P., Rickert, D.A., 1995, Mercury contamination of aquatic ecosystems: U.S. Geological Survey Fact Sheet 216-95, $4 \mathrm{p}$.

Kuwabara, J.S., Chang, C.C.Y., Pasilis, S.P., 2003, Effects of benthic fauna on arsenic transport in Whitewood Creek, South Dakota in Kuwabara, J.S., and Fuller, C.C., eds., Toxic substances in surface waters and sediment—A study to assess the effects of arsenic-contaminated alluvial sediment in Whitewood Creek, South Dakota: U.S. Geological Survey Water-Resources Professional Paper 1681, p. 1-26.

Leib, K.J., Mast, M.A., Wright, W.G., 2003, Using waterquality profiles to characterize seasonal water quality and loading in the Upper Animas River Basin, southwestern Colorado: U.S. Geological Survey Water-Resources Investigations Report 2002-4230, 43 p.

Mast, M.A., Evans, J.B., Leib, K.J., and Wright, W.G., 2000, Hydrologic and water-quality data at selected sites in the upper Animas River watershed, southwestern Colorado, 1997-99: U.S. Geological Survey Open-File Report 2000-53, 20 p.

Miller, L.D., Watts, K.R., Ortiz, R.F., and Ivahnenko, Tamara, 2010, Occurrence and distribution of dissolved solids, selenium, and uranium in groundwater and surface water in the Arkansas River Basin from the headwaters to Coolidge, Kansas, 1970-2009: U.S. Geological Survey Scientific Investigations Report 2010-5069, 59 p.

National Park Service, 2001, Baseline water quality data inventory and analysis, Rocky Mountain National Park: National Park Service, 1871 p., accessed June 2011, at http://nrdata.nps.gov/romo/nrdata/water/baseline_wq/docs/ ROMOWQAA.pdf.

Natural Resources Conservation Service, 2004, Mancos Valley Salinity Control Project - plan and environmental assessment: U.S. Department of Agriculture, 95 p., accessed December 2012, at http://www.usbr.gov/uc/library/envdocs/ ea/mancos_valley/index.html. 
Paschke, S.S., Kimball, B.A., and Runkel, R.L., 2005, Quantification and simulation of metal loading to the Upper Animas River, Eureka to Silverton, San Juan County, Colorado, September 1997 and August 1998: U.S. Geological Survey Scientific Investigations Report 2005-5054, 81 p.

Pliler, R., and Adams, J.A.S., 1962, The distribution of thorium, uranium, and potassium in the Mancos shale: Northern Ireland, Pergnmon Press Ltd., Geochimica et Cosmochimica Acta, v. 26, p. 1115-1135.

Rantz, S.E., and others, 1982, Measurement and computation of streamflow-Volume 1. Measurement of stage and discharge: U.S. Geological Survey Water-Supply Paper 2175, $284 \mathrm{p}$.

Reed, J.C., and Bush, C.A, 2007, About the geologic map in the National Atlas of the United States of America: U.S. Geological Survey Circular 1300, 52 p.

Richards, R.J, and Leib, K.J., 2011, Characterization of hydrology and salinity in the Dolores Project Area, McElmo Creek Region, southwest Colorado, water years 1978-2006: U.S. Geological Survey Scientific Investigations Report 2010-5218, $38 \mathrm{p}$

Schertz, T.L., Alexander, R.B., and Ohe, D.J., 1991, The computer program estimate trend (ESTREND), a system for the detection of trends in water-quality data: U.S. Geological Survey Water-Resources Investigations Report 91-4040, 63 p., available at http://pubs.er.usgs.gov/usgspubs/wri/ wri914040\%.

Seaber, P.R., Kapinos, F.P., and Knapp, G.L., 1987, Hydrologic unit maps: U.S. Geological Survey Water-Supply Paper 2294, 63 p.

Slack, J.R., Lorenz, D.L., and others, 2003, USGS library for S-PLUS for Windows-Release 2.1: U.S. Geological Survey Open-File Report 2003-357.

Smith, R.A., Hirsch, R.M., and Slack, J.R., 1982, A study of trends in total phosphorus measurements at NASQAN stations: U.S. Geological Survey Water-Supply Paper 2190, $34 \mathrm{p}$.

SYSTAT Software, Inc., 2004, SYSTAT 11, Statistics II-software documentation: Richmond, Calif., SYSTAT Software, Inc., $657 \mathrm{p}$.

TechniGraphics, Inc., 2004, Colorado's decision support system-2000 irrigated parcels: Accessed October 20, 2009, at http://cdss.state.co.us/DNN/GIS/tabid/67/Default.aspx/, within the downloadable Division 4 and 5 Layers GIS Files.

Thomas, J.C., Leib, K.J., and Mayo, J.W., 2008, Analysis of dissolved selenium loading for selected sites in the Lower Gunnison River Basin, Colorado, 1978-2005: U.S. Geological Survey Scientific Investigations Report 2007-5287, $25 \mathrm{p}$.
TIBCO, 2008, Spotfire $S+\bowtie 8.1$ for Windows ${ }^{\circledR}$ user's guide: TIBCO Software Inc., 2008, 572 p.

Tweto, Ogden, 1979, Geologic map of Colorado: U.S. Geological Survey, scale 1:500,000.

U.S. Environmental Protection Agency, 1977, STORET user handbook - the right answers for STORET users: U.S. Environmental Protection Agency, Office of Water and Hazardous Materials TD900U56, $604 \mathrm{p}$.

U.S. Environmental Protection Agency, 2010a, National primary drinking water regulations: U. S. Environmental Protection Agency, accessed October 21, 2010, at http://water.epa.gov/drink/contaminants/index.cfm/.

U.S. Environmental Protection Agency, 2010b, National secondary drinking water regulations: U.S. Environmental Protection Agency, accessed October 21, 2010, at http://water.epa.gov/drink/contaminants/index.cfm/.

U.S. Environmental Protection Agency, 2011, Basic information-Mercury: U.S. Environmental Protection Agency, accessed February 8, 2011, at http://www.epa.gov/mercury/ about.htm/.

U.S. Geological Survey, 1999, National elevation dataset: U.S. Geological Survey Fact Sheet 148-99, 2 p.

U.S. Geological Survey, 2011, National Water Information System, accessed October 2010 through June 2011, at http://waterdata.usgs.gov/co/nwis/sw.

Voggesser, Garrit, 2001, The Dolores Project: Information available on the Web, accessed February 16, 2011, at http://www.usbr.gov/projects//ImageServer? imagName= Doc_1303397411306.pdf.

Washington State Department of Ecology, 1994, A citizen's guide to understanding \& monitoring lakes and streams: State of Washington, Publication Number 94-149, 73 p.

Watts, K.R., 2000, Effects of the Paradox Valley Unit on dissolved solids, sodium, and chloride in the Dolores River near Bedrock, Colorado, water years 1988-98: U.S. Geological Survey Water-Resources Investigations Report 00-4011, 8 p.

Wenrich-Verbeek, K.J., 1980, Geochemical exploration for uranium utilizing water and stream sediments: U.S. Geological Survey Open-File Report 80-359, 36 p.

Wright, W.G., and Butler, D.L., 1993, Distribution and mobilization of dissolved selenium in groundwater of the irrigated Grand and Uncompahgre Valleys, western Colorado, in Allen, R.G., and Neale, C.M.U., eds., Management of irrigation and drainage systems - Integrated perspectives: American Society of Civil Engineers, Proceedings of the 1993 National Conference on Irrigation and Drainage Engineering, Park City, Utah, July 21-23, 1993, p. 770-777. 
Wright, W.G., Simon, W., Bove, D.J., Mast, M.A., and Leib, K.J., 2007, Distribution of $\mathrm{pH}$ values and dissolved tracemetal concentrations in streams, in Church, S.E., von Guerard, Paul, and Finger, S.E., eds., Integrated investigations of environmental effects of historical mining in the Animas River watershed, San Juan County, Colorado: U.S. Geological Survey Professional Paper 1651, v. 1, chap. E10, p. 497-541.

Zielinski, R.A., Asher-Bolinder, A., and Meier, A.L., 1995, Uraniferous waters of the Arkansas River valley, Colorado, U.S.A.-A function of geology and land use: Applied Geochemistry, v. 10, p. 133-144.

Publishing support provided by:

Denver Publishing Service Center

For more information concerning this publication, contact:

Director, USGS Colorado Water Science Center

Box 25046, Mail Stop 415

Denver, CO 80225

(303) 236-4882

Or visit the Colorado Water Science Center Web site at:

http://co.water.usgs.gov/ 
Appendix

$\longrightarrow$ 


\section{Assessment of Historical Surface-Water Quality Data in Southwestern Colorado, 1990-2005}

Appendix 1. U.S. Environmental Protection Agency typical range of values for selected water-quality parameters (U.S. Environmental Protection Agency, 1977).

[U.S. Environmental Protection Agency, USEPA; Minimum sample value, minimum value from the data repository (http://rmgsc.cr.usgs.gov/ cwqdr/Southwest/index.shtml) used in the analysis; Maximum sample value, maximum value from the data repository used in the analysis; ${ }^{\circ} \mathrm{C}$, degrees Celsius; $\mu \mathrm{S} / \mathrm{cm}$, microseimen per centimeter; $\mathrm{mg} / \mathrm{L}$, milligram per liter; $\mathrm{N}$, nitrogen; $\mathrm{P}$, phosphorus; $\mathrm{CaCO}_{3^{\prime}}$ calcium carbonate; $\mathrm{NO}_{3^{\prime}}$ nitrate; $\mu \mathrm{g} / \mathrm{L}$, microgram per liter; OK, measured values were within USEPA's typical range of values for the selected water-quality parameter; 9999, one or more measured values were outside of USEPA's typical range of values for the selected water-quality parameter but were used in the analysis because the value(s) were considered reasonable for the study area]

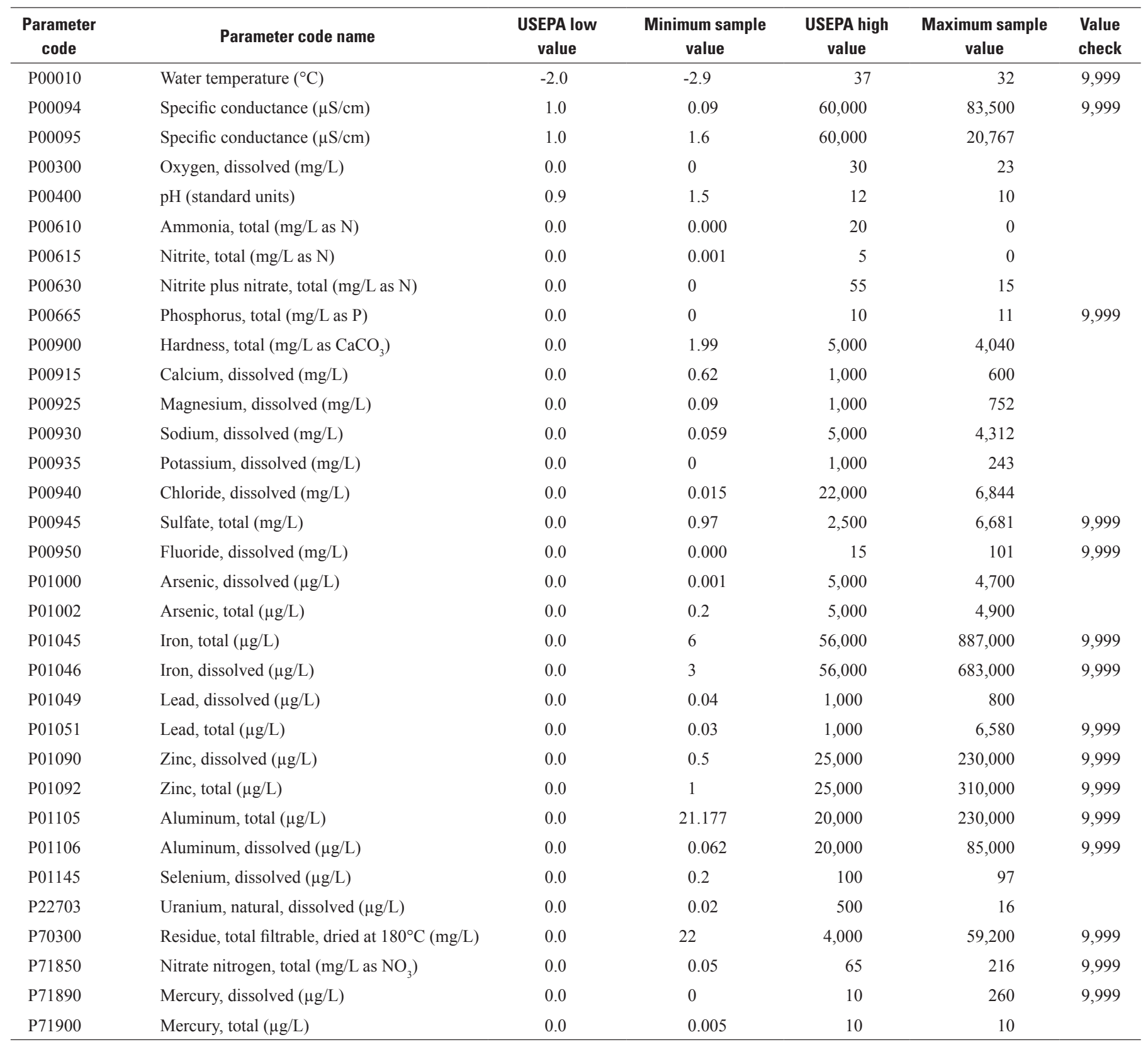


